UNIVERSIDADE DE SÃO PAULO

FACULDADE DE FILOSOFIA LETRAS E CIENCIAS HUMANAS

SARITA MUCINIC SARUE

\title{
JANUSZ KORCZAK DIANTE DO SIONISMO
}

Versão Corrigida

São Paulo

2011 


\section{JANUSZ KORCZAK DIANTE DO SIONISMO}

Dissertação apresentada à Área de Língua Hebraica, Literatura e Cultura Judaicas, do Departamento de Letras Orientais da Faculdade de Filosofia, Letras e Ciências Humanas da Universidade São Paulo para obtenção do título de Mestre em Letras.

Área de concentração: Língua Hebraica, Literatura e Cultura Judaicas. Orientadora Prof $^{\mathrm{a}}$. Dra ${ }^{\mathrm{a}}$. Ana Szpiczkowski 


\section{JANUSZ KORCZAK \\ DIANTE DO SIONISMO}

Dissertação apresentada à Área de Língua Hebraica, Literatura e Cultura Judaicas, do Departamento de Letras Orientais da Faculdade de Filosofia, Letras e Ciências Humanas da Universidade São Paulo para obtenção do título de Mestre em Letras.

Área de concentração: Língua Hebraica, Literatura e Cultura Judaicas. Orientadora Prof $^{a}$. Dr ${ }^{a}$. Ana Szpiczkowski

Versão corrigida

BANCA EXAMINADORA:

São Paulo, de de 2011 
Dedico esta pesquisa aos meus pais, Sam Mucinic (Israel) Z'L' e Hene Leja (Léia) Mucinic, nascidos na Romênia e Lituânia, respectivamente. Refugiados do nazismo e movidos pelo desejo de encontrar uma terra de paz chegaram ao Brasil. 



\section{Poesia em prosa para Janusz Korczak}

Se é verdadeira a lenda de que o Profeta Elias vem à Terra de tempos em tempos para alegrar e orientar os seres carentes, acredito que você, Janusz Korczak, médico, educador e escritor excelente, deve ter sido a reencarnação de um anjo do bem, que veio ao mundo para melhorá-lo através da criança. Se fazer esta poesia é ter sensibilidade, ainda que eu não saiba fazer rima à moda antiga, então, modéstia à parte, sou poetisa.

Falar sobre você, Janusz Korczak, é sentir-se em estado de graça, de comoção sem limites, pois sua obra, sua dedicação à criança desamparada, e por que não, a todas as crianças, em geral, é algo incrível na época mais cruel de todos os tempos da Segunda Guerra Mundial. Seu imenso amor aos pequenos desprotegidos fez com que fundasse, auxiliado por colaboradores dedicados, um orfanato judaico modelo, em Varsóvia no ano de 1912, na Rua Krochmalna $n^{\circ} 92$.

Você também foi bom para os católicos quando aceitou ser conselheiro pedagógico de um orfanato cristão por longos dezessete anos. No lar que você, Janusz Korczak, proporcionou às crianças judias, elas viviam como numa verdadeira república democrática, com constituição, parlamento, tribunal, juiz e jornal. Tudo isso num clima de amor e carinho, sob a orientação de um verdadeiro pai, você, Janusz Korczak, que os ensinou a serem cidadãos úteis e responsáveis de uma sociedade Ideal. As entidades, como a FEBEM, deveriam com urgência se espelhar em sua obra, sem igual.

A superpopulação, aliada ao despreparo e à ausência de amor e compaixão, geram essa violência sem medida a que assistimos periodicamente nos noticiários da televisão. Pessoas como você, Janusz Korczak, não deveriam morrer, mas, não foi possível, e marchou, heroicamente, à frente de seus duzentos "filhos", com dois pequeninos, um em cada braço, em 1942, para a câmara de gás desse terrível campo de extermínio de Treblinka.

Sabe-se de fontes fidedignas, que poderia ter sido salvo, mas não o quis e preferiu seguir seus protegidos. Deus Todo Poderoso, faça com que os adultos ligados á área pedagógica aprendam com você, Janusz Korczak, com sua genuína humildade e enraizada bondade, e que disse uma vez: "Fazer o mal? Não sei como isso se faz!”, a diminuir essa quase incontrolável violência e corrupção, que ultimamente imperam na Aldeia Global, tanto em países super-desenvolvidos como os Estados Unidos, e nos não tão adiantados como o Brasil.

Se fosse possível, seu trabalho devia ser mostrado e praticado em cada canto deste nosso País Continental, para quem sabe e Deus o queira, um dia surgir uma geração melhor, mais humana, mais justa e solidária, sem exploração do homem pelo homem, dando início a um novo tempo, nova era. A sua herança, Janusz Korczak, não foi material, mas foi esse universo espiritual que durará para sempre. Você sabia que uma semente para dar frutos sadios precisa ser muito bem cuidada e amada!

Hene Leja (Léia) Mucinic ${ }^{1}$

\footnotetext{
${ }^{1}$ Minha mãe nasceu na Lituânia 1/1/1929 e chegou ao Brasil em 15/08/1939 juntamente com sua mãe e mais quatro irmãos. Escreveu essa poesia em prosa em 1999 aos 70 anos de idade.
} 


\section{AGRADECIMENTOS}

Agradeço especialmente à minha orientadora $\operatorname{Prof}^{\mathrm{a}}$. Dra . Ana Szpiczkowski pela paciência e incentivo de me conduzir sabiamente nessa jornada, e ao corpo docente do Programa de Pós-Graduação em Língua Hebraica, Literatura e Cultura Judaicas coordenado pela Prof ${ }^{a}$. Dra ${ }^{a}$. Suzana Chwarts.

Aos queridos amigos que me deram o incentivo inicial na tradução do hebraico como Marcel Berditchevsky, Moshe e Hana Midler e minha querida eterna Morá Miriam Smaletz Z"L".

À Raquel Mizrahi, Miriam Swartz, Ruth Joanas Solon e Hélio Daniel e Dora Mucinic Cordeiro, Daniela Guertzenstein e Ruth Lerner Sarue.

À Sandra Becker, Tânia Abramovicz, Jane Sragowicz Freund e Isabella Becker.

À Vera Pilnik Sanovicz por todo seu profissionalismo, carinho e dedicação.

À minha mãe por seu envolvimento com a pesquisa.

Aos meus filhos pelo carinho e otimismo: Maurício, Eduardo e Adriana.

E finalmente ao Beto, meu marido, meu porto seguro e que com amor e incansável apoio me incentivou à elaboração desta pesquisa. 
Nada damos a vocês. Não damos Deus, porque a Ele deveis encontrar vós mesmos na própria alma, em esforço solitário. Não damos a Pátria, porque encontrá-la será pelo trabalho próprio do coração e do pensamento. Não vos damos amor humano, porque não existe amor sem perdão, $e$ perdoar é sofrer e se esforçar, o que cada um deve enfrentar por si mesmo. Nós damos uma coisa: nostalgia de uma vida melhor, que não existe, porém que um dia existirá; saudades da Verdade e da Justiça. É possível que esta saudade vos guie a Deus, à Pátria e ao Amor. 


\section{RESUMO}

Este trabalho se propõe a estudar Janusz Korczak e sua relação com o judaísmo e o sionismo. Korczak foi um judeu-polonês, nascido em Varsóvia em 1878, e pertencia a uma família de eruditos bastante assimilada, sentindo-se um verdadeiro polonês. Foi médico, educador, jornalista, escritor e criador de dois orfanatos baseados nos princípios democráticos de educação: um judaico, Don Sierot (1912-1942); e outro cristão, Nasz Dom (1919-1936).

A análise de correspondências, relatos de viagem, entrevistas, entre outros documentos associados à relação de Korczak com o judaísmo, o sionismo e a Terra de Israel, permitiu conhecer a visão de Korczak sobre a questão judaica em uma Polônia antissemita dos séculos XIX e XX. No tocante aos relatos de viagem, foram analisados documentos referentes às duas viagens do autor à Terra de Israel, incluindo impressões pessoais referentes tanto aos benefícios dessa Terra, como às dificuldades de adaptação à terra dos ancestrais e o abandono da terra natal. Korczak pretendia emigrar para a Palestina, porém foi vítima da Shoá e juntamente com as duzentas crianças judias e os educadores do orfanato, foi levado do Gueto de Varsóvia para o trem que os levaria a Treblinka.

Palavras-chave: Identidade. Judaísmo. Sionismo. Terra de Israel. Shoá 


\section{ABSTRACT}

The present work intends to study Janus Korczak and his relation with judaism and sionism. Korczak was a polish jew, borned in Warsaw, in 1878, who belonged to a family of assimilated scholars and felt trully polish. He was a phisician, an educator, a journalist, a writer and founder of two orphanages, that followed the democratic principles of education: one of them jewish, Don Sierot (1912-1942) ) and the other one christian, Nasz Dom (1919-1936).

The analysis of correspondences, interviews, and other documents related to judaism, sionism and the land of Israel, allowed us to aknowledge Korczak's vision of the jewish question in an antisemitic Poland of the 19th and 20th centuries. The documents analised referred mainly to the two trips that Korczak made to the land of Israel, and included his personal impressions of the benefits of the Land, as well as the difficulties of adaptation to this ancestral ground, and of leaving the homeland for good. Altough Korczak intended to emigrate to Palestine, he was not able to do it, because as a victim of the Shoah, he was sent, with the 200 jewish children and the teachers of his orphanage, from the Guetto of Warsaw to the train hat would lead them to Treblinka.

Key-words: Identity. Judaism. Zionism. Land of Israel. Shoá 


\section{SUMÁRIO}

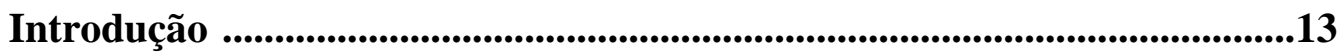

1. Janusz Korczak: ................................................................................................18

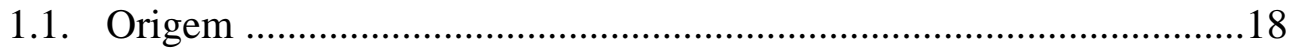

1.2. De Henryk Goldszmit a Janusz Korczak ...........................................25

1.3. Formação e atuação voluntária e profissional .....................................28

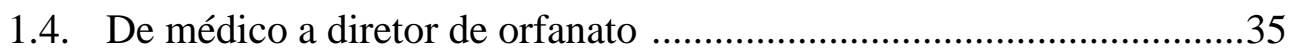

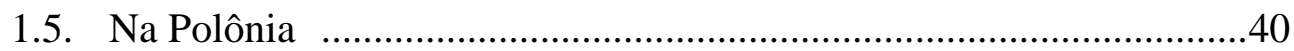

1.6. Encontro com a Terra de Israel ........................................................4

1.7. Vítima do nazismo ...........................................................................

2. Rumo ao Sionismo …………………...................................................................50

2.1. Judeu - Polonês ……………………………………………….... 50

2.2. Movimento Sionista .........................................................................

2.2.1. Desenvolvimento....................................................................

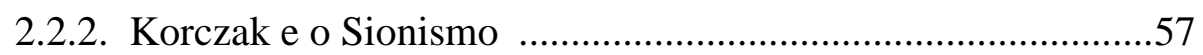

3. Korczak e a Terra de Israel: Análise de Documentos ..............................68

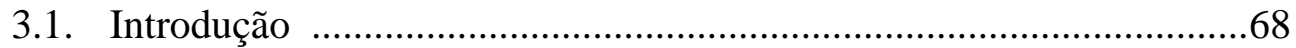

3.2. De 1926 a $1934 \ldots \ldots$

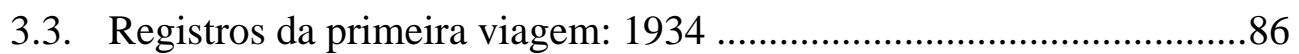

3.3.1. Impressões de Korczak ............................................................95

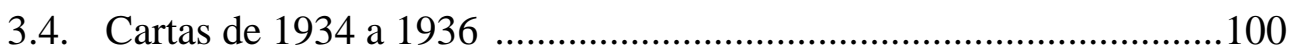

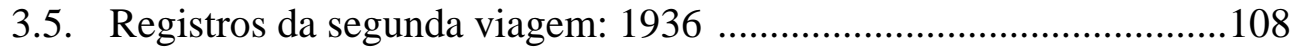

3.5.1. Impressões de Korczak .......................................................120

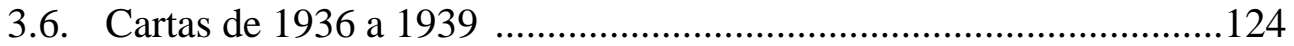

4. Considerações finais ........................................................................................131

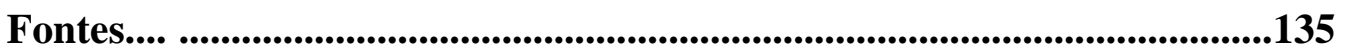

Iconografia......................................................................................................136

Bibliografia................................................................................................................139 


\section{Introdução}

eu interesse por Janusz Korczak advém do tempo em que cursava a
graduação em pedagogia, principalmente, após ler o livro de sua autoria Quando voltar a ser criança (1926), que despertou em mim a curiosidade de partir em busca de novos conhecimentos.

Considerado como um dos mais importantes educadores judeus do século $\mathrm{XX}$ e pioneiro nos estudos dos direitos da criança, Korczak formou-se em medicina, mas praticamente abandonou seu trabalho em hospital para voltar-se principalmente à educação de crianças. Ele sonhava com uma sociedade mais justa, e acreditava que o único meio para a transformação da mesma se encontrava no terreno de uma educação que atribuísse direitos às crianças.

Korczak criou e dirigiu orfanatos, Don Sierot (orfanato judaico) e Nasz Dom (orfanato polonês). Neles ele acolhia crianças das ruas e órfãos, em meio à grande crise econômica que assolava a Polônia, no período entre a guerra russo-japonesa (1904-1905) e a Primeira Guerra Mundial (1914-1918). Nesses orfanatos, ele praticava a pedagogia democrática e inovadora com um modelo de autogestão e de grande respeito às crianças e jovens. Essa foi sua obra vital, pois trouxe novo conhecimento sobre o universo infantil, seus direitos e sua dignidade. A obra de Korczak, O Direito da Criança ao Respeito, escrita em 1929, serviu de base para a Declaração dos Direitos da Criança da UNESCO, proclamada pela ONU em 20 de novembro de $1959^{1}$.

Reconhecido por sua vasta produção literária e prática pedagógica, que muito influenciou e enriqueceu o moderno conceito da infância, Korczak escreveu diversos trabalhos, como artigos, peças satíricas e humorísticas, livros sobre a infância e educação, além de contos e histórias juvenis.

\footnotetext{
${ }^{1}$ In KORCZAK, J. \&Dallari, D.A. O Direito da Criança ao Respeito, São Paulo, Summus, 1986.
} 
De família judia assimilada à cultura polonesa, Janusz Korczak, pseudônimo literário adotado por Henryk Goldszmit, nasceu em 22 de julho de 1878 (ou 79)², em Varsóvia e morreu no campo de extermínio de Treblinka, em 1942, durante a Shoá.

Mas foi durante minha participação como aluna de Mestrado em Língua, Literatura e Cultura Judaicas da USP que descobrimos outros aspectos desta figura emblemática: sua relação com o judaísmo e com o sionismo.

Ao sairmos em busca da fortuna crítica relativa ao tema em questão, deparamo-nos com especialistas na história de vida de Janusz Korczak, dentre os quais damos destaque a Tali Shner (2008), Moshe Shner (2008), Itzkhak Perlis (1990), Joseph Arnon (2005), Schevakh Éden (2000), Betty Lifton (2005), Yerachmiel Weingarten (1979), Anita Novinsky (2005) e Ana Szpiczkowski (2002), entre outros.

O fato de utilizarmos uma larga bibliografia no idioma hebraico, traduzida de fontes polonesas, exigiu um tempo maior na nossa pesquisa, com fins de interpretação e adequação à língua portuguesa. A leitura e análise desses documentos podem levar ao leitor a diferentes interpretações linguísticas ou psicológicas, mas, nessa pesquisa, nos ativemos à contextualização histórica dos tempos vividos por Korczak, tanto na Polônia como na Palestina, que o levaram a registrar as próprias impressões e sentimentos concernentes à Terra de Israel e à difícil situação vivida pelos judeus na Polônia. O idioma hebraico é, para nós, uma língua estrangeira, fato que exigiu tradução, compreensão e adaptação de conceitos necessários para a interpretação de textos relativos à vida de Korczak, às suas ideias sobre o vínculo com a questão judaico-polonesa e ao sionismo.

As viagens para Israel, onde participamos de encontros com Tali Shner em 2010 e 2011, nos conduziram ao conhecimento de documentação existente sobre o tema em questão, fato que nos levou a buscar o estudo da relação de pertinência de Janusz Korczak aos princípios sionistas de sua época com base na análise das cartas e dos artigos e registros aqui mencionados. Essa pesquisa inclui algumas cartas, artigos, registros pessoais escritos por Korczak para seus discípulos e amigos entre os anos de 1926 a 1939, bem como material

\footnotetext{
${ }^{2}$ Perlis (1986) foi amigo de Korczak e ambos se conheceram nos final dos anos 30. Ele escreveu a biografia de Korczak, no livro Ish Iehudi Mepolin [O homem judeus polones] e levantou a dúvida sobre o ano de nascimento de Korczak.
} 
coletado por Tali Shner (2008), referente aos registros da passagem de Korczak pelos Kibutzim $^{3}$ e Moshavim ${ }^{4}$ na Palestina em 1934 e 1936.

O interesse de Korczak pela Terra de Israel foi documentado em cartas enviadas a amigos e discípulos. De acordo com Perlis (1986, p.118), o material atual é constituído por 49 cartas, original ou cópia, para seus amigos e discípulos, sendo que boa parte já foi publicada. Uma parte dessas cartas são as respostas de Korczak às correspondências enviadas a ele, e são testemunhos importantes para compreender suas ideias sobre os problemas da época, baseadas em descrições e sentimentos sobre a Polônia, sobretudo pensamentos e preocupações referentes a seu destino e o das crianças do orfanato. Um espaço especial nestas cartas está reservado à sua compreensão sobre os problemas da Terra de Israel e sua ligação com esse tema por de seu interesse constante em saber da realidade vivida lá.

Para tanto, esse trabalho será assim constituído: o primeiro capítulo intitulado "Janusz Korczak: Breve biografia" pretendeu apresentar a família de ascendência judaica, a infância e a formação acadêmica do educador polonês, permeadas pela configuração histórica referente ao século XIX e XX, seu encontro com a Terra de Israel e finalmente sua morte como vítima da Shoá. Korczak teve algumas oportunidades de ser salvo do gueto de Varsóvia assim como do campo de concentração de Treblinka, porém escolheu ficar ao lado das duzentas crianças e dos educadores.

O segundo capítulo, "Rumo ao Sionismo", referiu-se à questão da identidade de Korczak como judeu e polonês e uma apresentação da formação da ideia sionista que trouxe a Korczak uma nova realidade da possibilidade de uma terra onde se criança pudesse desenvolver plenamente livre de preconceitos e do isolamento social.

O terceiro capítulo destinou-se à análise da documentação das viagens de Korczak à Palestina, onde esteve por duas vezes: em 1934 e 1936. Essa documentação inclui os registros sobre a segunda viagem de Korczak à Terra de Israel que estavam contidos na palestra proferida por Korczak, em novembro de 1936, para os líderes comunitários e o público

\footnotetext{
3 Kibutzim: do hebraico, plural de kibutz, comuna. Fundada como uma comunidade na qual não existe propriedade privada e que atende, com igualdade, às necessidades de seus membros, que se agregam voluntariamente, atraídos por ideias e propósitos afins. O kibutz, criado em 1909 por jovens pioneiros imigranntes, foi originalmente uma colônia agrícola, estabelecida em terras adquiridas a título de propriedade inalienável do povo judeu pelo Fundo Nacional Judaico (KKL). Em BORGER, 2002, p. 461.

${ }^{4}$ Moshavim: do hebraico, plural de moshav. Uma colônia dentro de um modelo de sistema corrporativista que combina iniciativa individual e ação coletiva. Também instalada em terras do Fundo Nacional, o moshav mantém comunitariamente a infraestrutura de prédios, máquinas e irrigação, ensino, saúde, recreação e cultura. Individualmente, cada família trabalha seu terreno, tem casa, comida e lazer próprios e cria seus filhos onde e como quer. A produção é vendida em conjunto, creditada proporcionalmente e taxada para o fundo comum. Ver: BORGER, 2002, p.462.
} 
judaico de Varsóvia. Suas palavras baseavam-se em 940 itens registrados em sua viagem. De sua primeira viagem, havia 16 cadernos com 1400 itens, porém esse material não foi publicado, e nada se sabe sobre seu destino. Da sua segunda viagem, havia 12 cadernos escritos com 1000 itens que ele anotou.

Há também as cartas pessoais de Stefa Wilczinska, sócia e educadora no orfanato, para a discípula e amiga íntima Feiga Lipshitz, que morava no Kibutz Ein Harod. Essas cartas contêm informações do cotidiano do orfanato, do trabalho e do estado emocional do "Doutor Korczak”, como ela o chamava. Grande parte das cartas de Stefa não está datada e encontra-se numa situação precária de conservação. Nesse material incluem-se as cartas das crianças do orfanato enviadas por Stefa quando esta se encontrava em Israel no Kibutz Ein Harod, e testemunhos escritos por amigos e discípulos.

Parte desta documentação foi relacionada por Moshe Shner, Tali Shner, Joseph Arnon e Itzkhak Perlis e serviu de base para o presente estudo. Além disso, a correspondência compilada no livro de Dat Hayeled, que reúne cópias dos originais em polonês traduzidas para o idioma hebraico, também serviu de fonte para nossa pesquisa.

O diário escrito por Korczak no gueto de Varsóvia entre os anos de 1939 e 1942 constitui uma fonte de profundo conhecimento pessoal, familiar, filosófico e histórico da vida deste homem, que nos auxiliaram na realização desse trabalho.

O critério utilizado para a seleção da documentação a ser analisada foi de buscar nos documentos existentes unicamente trechos pertinentes ao propósito deste estudo e que envolvem as seguintes questões:

a. Relação de Korczak com a Terra de Israel;

b. Dilemas identitários relativos à condição de Korczak como judeu e polonês;

c. Incertezas de Korczak em relação à sua imigração para a Terra de Israel;

d. Intranquilidade/Tranquilidade de Korczak relativas à adaptação à Terra de Israel.

Finalmente, o quarto capítulo apresentou as considerações finais sobre Korczak, que por de sua influência como médico, jornalista, escritor e educador aceito e reconhecido pela elite da sociedade polonesa, defendeu as crianças judias da forma que pôde, contra as arbitrariedades que elas sofreram com as leis antissemitas se evidenciando progressivamente. No entanto, como judeu também sofreu as atrocidades praticadas sob o crescente 
antissemitismo. Surpreendentemente colocou-se entre estes dois mundos e transitou livremente indo e voltando de suas viagens à Terra de Israel, numa época difícil de se obter passaporte e visto, sob as restrições de entrada na Palestina sob as leis do mandato britânico. De volta das viagens, mostrou-se um visionário nas questões mais contundentes relativas ao pioneirismo dos jovens judeus em seu empreendimento de construção de uma nova terra. Questionou a situação das crianças árabe, da convivência pacífica e também pontuou aspectos relativos à perda da pátria original no sentido da construção de uma nova identidade.

A transliteraçao linguística das palavras traduzidas do hebraico seguiu a orientação da Prof ${ }^{a}$. Dr ${ }^{a}$. Rifka Berezin. 


\section{Janusz Korczak: Breve Biografia}

\subsection{Origem}

Janusz Korczak nasceu Henryk Goldszmit. Para entendermos o homem Janusz Korczak precisamos conhecer primeiro a criança Henryk Goldszmit e a história de sua família.

Henryk nasceu em 1878, na cidade de Varsóvia, descendente de uma das poucas famílias da elite judaica integrada à sociedade polonesa. Os Goldszmit contituíam uma família de maskilim: eruditos judeus, estudiosos do pensamento iluminista que pretendiam revolucionar as bases da vida, da educação e do pensamento judaico. Henryk representava a terceira geração, da família instruída em curso superior, que adotava uma vida judaica secular.

O avô de Henryk, Hirsh Goldszmit, nasceu em 1805, em Hrubieszow. Foi o primeiro médico do pequeno hospital judaico da cidade, localizada a sudeste de Lublin e uma das mais importantes comunidades judaicas da Polônia (ERTEL, 2010, p. 277), com fama internacional e ocupada, na época, pelo império austríaco.

Nesse período, a Polônia, passava por contínuas guerras e crises econômicas que se prolongaram por mais de cem anos. O país foi condenado ao desaparecimento e seu território foi dividido entre Rússia, Prússia e Áustria nas partilhas de 1772, 1793, e 1795. Quando em $1807^{5}$ Napoleão restabeleceu, por pouco tempo, o Estado polonês - o Ducado de Varsóvia houve um intenso envolvimento do governo na promoção social de grande parte da comunidade judaica, para intensificar a reputação de Napoleão como protetor e regenerador do povo judeu (Seltzer, 1989, p.525). Após a derrota de Napoleão em 1815, o Congresso de Viena tornou a dividir a Polônia e a porção oriental ficou sob domínio russo. Nesta época, novecentos mil judeus viviam dentro das fronteiras russas. (EBAN, 1973, p. 227) A grande maioria dos judeus lituano-poloneses ficou sob o regime czarista, confinados a Cherta - Zona

\footnotetext{
${ }^{5}$ Em 1807, Napoleão concebeu o projeto audacioso de convocar, mais de dezessete séculos depois de seu desaparecimento, a mais alta instância do judaísmo, o Grande Sinédrio. Composto por setenta e um membros, sendo dois terços rabinos, ele veria seus autos "situados junto ao Talmude, para serem artigos de fé e princípios de legislação religiosa". Com este gesto inusitado, o novo César, então no ápice de seu poder, pretendia pôr em cena, com estardalhaço, sua magnitude, e dar uma ressonância bastante particular às declarações da Assembléia dos notáveis (escolhidos entre rabinos e outros para representação do povo), assim homologada. (ERTEL, 2010, p. 187).
} 
de Residência ${ }^{6}$ - fora da qual era proibido morar; sua área era de aproximadamente um milhão de quilômetros quadrados e abrangia a antiga Polônia, Ucrânia, Bielo-Rússia e Lituânia (BORGER, 2002, p.308).

Como médico da cidade e líder comunitário, Hirsh dedicou a vida à solução do problema da emancipação e da integração dos judeus à sociedade secular influenciado pelo movimento iluminista judaico, a Haskalá. A Haskalá, inspirada nos ideais iluministas de luta pelos direitos iguais entre os homens e de superação dos privilégios da nobreza, defendia a integração do judeu à sociedade europeia e a valorização da educação secular. Esse movimento trouxe à maioria dos judeus da Europa a possibilidade de ascensão social, diferente da situação marginal e periférica do fim do século XVIII. ${ }^{7}$

Hirsh, assim como os primeiros humanistas, buscava soluções para diminuir o isolamento da aldeia judaica e seu atraso cultural e foi inspirado pelas ideias de Moses Mendelssohn, judeu alemão, a primeira figura judaica proeminente a fazer a transição do gueto para a modernidade sem romper com o povo judeu (SELTZER, 1989, vol.II, p. 564).

$\mathrm{Na}$ cidade de Hrubieszow havia seis mil habitantes, entre eles três mil judeus (LIFTON, 2005, p.22) que se utilizavam de duas línguas no âmbito familiar: a língua sagrada ${ }^{8}$ e o iídiche ${ }^{9}$, enquanto fora de casa falavam o polonês. Segundo Perlis (1986, p. 24), ao se

\footnotetext{
${ }^{6}$ Quando a Polônia foi dividida, em 1770, a Rússia "herdou” uma grande quantidade de súditos judeus. Para controlar essa população de "infiéis", permitiu-se que os judeus vivessem nos locais em que já moravam ou nos territórios recentemente anexados. A “Zona de Residência” seria oficialmente mantida até a Revolução Russa em 1917. (SHEINDLIN, 2004, p.252).

${ }^{7}$ O movimento da Haskalá [instrução] foi formado no fim do séc. XVIII pelos judeus emancipados da Alemanha, inspirados nas idéias do filósofo Moses Mendelssohn. Esse termo traduziu o fenômeno europeu das Luzes que foi um movimento militante que lutou pela integração dos judeus na sociedade moderna "civilizada", tendo o custo do abandono mais ou menos exacerbado das particularidades e da autonomia que caracterizavam as comunidades da Idade Média. Foi o período do nascimento das literaturas hebraica e iídiche modernas. Os judeus alcançaram posições importantes na literatura, na música, na ciência, na pintura, na filosofia, na economia, na psicologia e na política. Ver (SELTZER, 1989, p.565) e (TURNIANSKY, 2010, p.166). Com o surgimento do sionismo moderno, o hebraico começou a ser revivido, como a língua falada por Eliezer Ben Yehudá (1858-1922), que se recusou a falar qualquer outra língua, cunhou novas palavras e começou a compilar um grande dicionário hebraico sem palavras aramaicas ou estrangeiras. (UNTERMAN, 1991, p.114).

${ }^{8}$ A língua sagrada, também chamada hebraico, língua semítica é um idioma composto com uma mescla de hebraico, de aramaico e de vários outros elementos. Do século III da era cristã ao final do século XIX, o hebraico deixou de ser uma língua viva falada no cotidiano e cuja função se destinava-se ao estudo e á oração. A língua vernácula era o iídiche e a escrita era o hebraico. (TURNIANSKY, 2010, p.417).

${ }^{9}$ Iídiche é a língua judeo-alemã falada pelos Ashkenazim, judeus originários da Europa oriental, sendo o nome uma abreviação de Iídish-Daitsch, "alemão judaico". O iídiche surgiu quando os judeus se mudaram, durante a Idade Média, para os países eslavos do leste, após expulsão de países de língua alemã. Escreve-se com caracteres em hebraico, e $20 \%$ de suas palavras são hebraicas e aramaicas e 10\% de palavras eslavas. (UNTERMAN, 1991, p.121).
} 
dirigir a sua comunidade, Hirsh publicou um artigo no jornal judaico Hamaguid, em hebraico erudito $^{10}$, sobre as necessidades do hospital judaico.
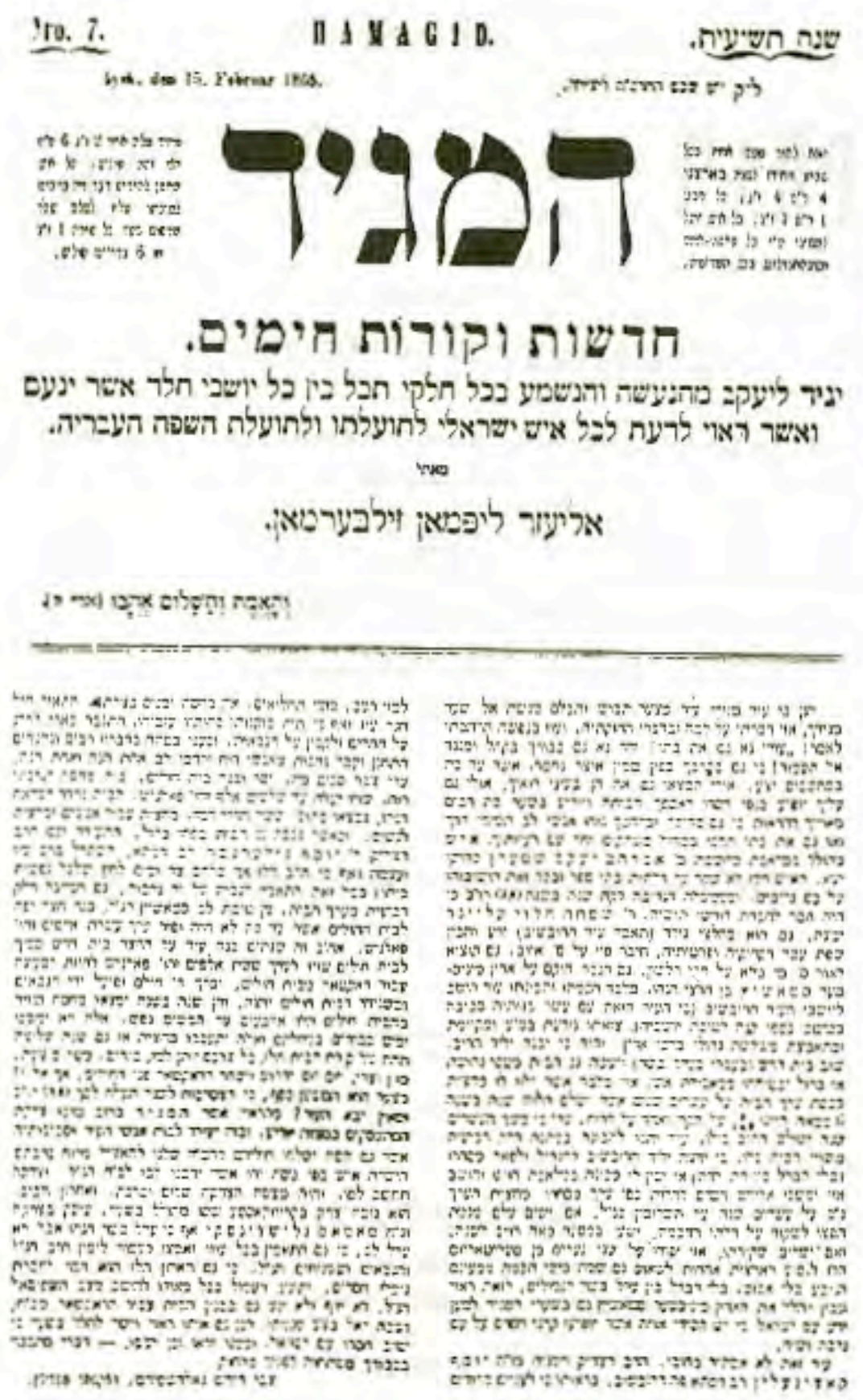

Imagem 01 - A primeira página do jornal "Hamaguid" do dia 5/02/1865 contendo o artigo escrito por Hirsh Goldszmit, com sua assinatura no final do artigo à esquerda. Fonte: EDEN, 2000, p. 239.

\footnotetext{
${ }^{10}$ A literatura judaica moderna tem sua origem na Haskalá. A língua hebraica começou a ser utilizada num contexto literário sem a interferência do pensamento e da legislação rabínica a partir das últimas décadas do séc. XVIII. E a literatura tornou-se bilíngue, em iídiche e em hebraico. (NIBORSKI, 2010, p.447)
} 
Ser judeu, segundo Avineri (1988, p.21), nessa nova situação, implicava uma mudança de percepção da própria identidade judaica e da percepção que a sociedade tinha sobre deles. Ao dilema provocado por esta nova identidade moderna, dentro do contexto do liberalismo, devemos agregar as questões originadas pelo nacionalismo. Segundo Hobsbawm (1990, p.30), o sentido moderno e político do conceito de nação é historicamente recente. Foi com a Revolução Francesa que se difundiram as ideias do liberalismo, da secularização e também do nacionalismo. Os iluministas e os liberais acreditavam que o sentimento antijudaico medieval iria desaparecer progressivamente sob a influência do pensamento racional. O judeu moderno, secularizado e instruído, por sua vez, não foi incorporado integralmente às nações emergentes, pois não compartilhava da mesma história, nem do mesmo passado étnico e linguístico, base do nacionalismo do século XIX. Na Europa do século XIX, o judeu não pertencia a qualquer classe social específica e, dependendo do ângulo pelo qual se olhava para ele, era possível compreendê-lo de modo antagônico: como alguém de classe inferior, rude, sem requinte, brutal e ao mesmo tempo como de classe superior, cruel e arrogante ${ }^{11}$ (BAUMAN, 1989, p.64).

Hirsh e seus colaboradores estavam convencidos de que a assimilação não constituía perda da identidade judaica, mas representava apenas a aceitação do judeu como cidadão polonês. Ele faleceu em 1874, alguns anos antes do nascimento de seu neto Henryk, sem conhecer e vislumbrar uma solução para a questão judaica de transformar o homem judeu num cidadão do mundo secular.

Hirsh e Hanna tiveram cinco filhos ${ }^{12}$ que receberam educação secular preservando a identidade judaica. Na infância, estudaram na escola judaica de Hrubieszow, pois, como as maiorias dos maskilim acreditavam que era importante dar às crianças os fundamentos da Torá no ensino fundamental da escola judaica, para posteriormente ingressar no ensino médio secular.

\footnotetext{
${ }^{11}$ Para população comum, os judeus eram vistos como inimigos porque eram funcionários da nobreza e de pequenos fidalgos. Eram encarregados de funções públicas impopulares, executando serviços como a coleta de rendas e a administração da produção camponesa. Essa função intermediária suscitava à antipatia de ambas as classes da sociedade. Para a elite, o judeu era visto com desprezo principalmente por aceitar recompensas financeiras, já que não lhes era permitido à ascensão social. Para a população simples, o judeu era considerado explorador pertencente às classes dominantes. Segundo Anna Zuk (apud BAUMAN, 1998, p.62), os judeus pertenciam a uma "classe móvel", sendo alvo de emoções antagônicas, e isso pode servir de base para a compreensão do antissemitismo moderno.

${ }^{12}$ No seu livro Diário do Gueto (1986, p.114), Korczak conta que seus avós paternos, Hirsh e Hanna, tiveram cinco filhos e deram a eles nomes judaicos e cristãos: Maria, Madalena, Ludwik, Joseph, Jakub e Karol. Porém, o livro de Perlis (1986, p.24) contém a informação de que no atestado de óbito de Hana, avó de Korczak, estão escritos os nomes dos filhos assim: Maria, Mindel, Lazer, Yosef e Iankel.
} 
Ludwik, um dos cinco filhos de casal, converteu-se ao catolicismo aos dezoito anos (Lifton, 1988, p.21), atitude comum na época devido ao engajamento dos jovens no movimento revolucionário de libertação do país contra o domínio russo. Em 1830, ondas de protestos em toda a Europa contra as decisões do Congresso de Viena influenciaram os poloneses a buscarem a libertação do país. O levante armado fracassou, assim como havia fracassado a outra tentativa de libertação em 1848, durante a Primavera dos Povos (Revoluções de 1848). ${ }^{13}$ Nesse período intensificou-se a "russificação" da Polônia com a substituição da língua polonesa pela russa nas escolas e na administração. As instituições de ensino foram proibidas de ensinar a história e a língua polonesa.

O filho de Hirsh, Joseph, pai de Henryk, nasceu em 1846 e estudou, na adolescência, no gymnasium polonês de Lublin. Mesmo sob domínio russo, os alunos inadvertidamente recitavam, na classe, os poemas patrióticos de autores poloneses, como Adam Mickiewicz, Julius Slowacki e Zygmunt Krasinki, poemas que Joseph ensinou ao filho Henryk no intuito de reviver os tempos de uma Polônia livre.

Joseph, assim como seu irmão Jakub, foi estudar advocacia em Varsóvia em 1860. Diferente de Hrubieszow, a cidade possuía quinhentos mil habitantes, dos quais sessenta mil eram judeus, que viviam numa situação de pobreza (Lifton, 2005, p.23). Joseph tinha aspirações literárias e escreveu seu primeiro artigo no jornal progressista em língua polonesa chamada Israelite (LIFTON, 2005, p.28) no qual relata as dificuldades e as impressões de um jovem provinciano ao chegar a uma cidade grande e movimentada como Varsóvia.

Assim como seu pai, os irmãos se dedicaram ao projeto de integração dos judeus na sociedade polonesa. Muitos anos depois Korczak escreveu:

Eu deveria consagrar aqui muito espaço ao meu pai (Joseph): realizo na vida aquilo a que ele mesmo aspirou tão forte e antes dele meu avô quis realizar (Korczak, 1986, p.115).

Joseph, assim como muitos de sua geração, decepcionado com a derrota da luta contra o regime czarista, estava imbuído do desejo de criar uma nação forte. A política antissemita havia se intensificado, a partir de 1882, limitando o contingente de judeus médicos militares e o acesso de advogados judeus aos tribunais, a 5\%, estes últimos tendo

\footnotetext{
${ }^{13}$ A Primavera dos Povos foi um conjunto de revoluções, de caráter liberal, democrático e nacionalista, iniciado por membros da burguesia e da nobreza que exigiam governos constitucionais.
} 
que ser submetidos à aprovação do Ministério da Justiça pela lei que perdurou até 1895. (WEILL, 2010, p.212-213).

Movido pelo ideal de que os judeus participassem com os poloneses desse processo de desenvolvimento econômico e social, Joseph trabalhou na arrecadação de fundos para a criação de escolas judaicas profissionalizantes para a juventude carente. Isso era necessário devido à instituição do numerus clausus pelo regime russo a partir de 1887 , um sistema de cotas limitando a proporção de rapazes judeus nos liceus e universidades a: $10 \%$ na zona de residência, 5\% fora dela e 3\% nas capitais. Em 1901, essa proporção foi reduzida para 7\%, $3 \%$ e $2 \%$, respectivamente. (WEILL, 2010, p.212-213). Nesse sentido, essas escolas criadas em Lublin e Varsóvia destinavam-se justamente aos jovens judeus que não tinham acesso às universidades e necessitavam de uma oportunidade para aprender ofícios e habilitar-se a integrar a força de trabalho polonesa. Isaac Bashevis Singer, que nasceu em 1904 na Polônia e viveu até os 35 anos em Varsóvia, descreveu em seu romance Shosha o perfil da maioria dos judeus carentes de Varsóvia:

Fui criado em três línguas mortas - hebraico, aramaico $^{14}$ e iídiche (alguns não consideram esta última como língua, absolutamente)-e numa cultura que se desenvolveu na Babilônia: o Talmude. O heder ${ }^{15}$ em que eu estudava era uma sala na qual o professor comia e dormia e sua mulher cozinhava. Ali não estudei nada de aritmética, geografia, física, química ou história, mas sim as leis que regem o ovo botado num feriado e os sacrifícios em um templo destruído há mais de dois mil anos.Embora meus ancestrais se tenham estabelecido na Polônia uns seiscentos ou setecentos anos antes de eu nascer, só aprendi algumas palavras da língua polonesa. Vivíamos em Varsóvia, na rua Krochmalna, que bem podia ser chamada de gueto. (BASHEVIS SINGER,1978, p.9):

Joseph e Jakub, conhecidos como os irmãos Goldszmit, escreveram uma série de artigos publicados em jornais e livros com destaque para "Retratos de Judeus famosos do século XIX". No primeiro volume, dedicado a seu pai Hirsh (Perlis, 1986, p.25), Joseph escreve sobre Moses Montefiore ${ }^{16}$ e suas obras assistenciais na Europa e na Palestina A maior

\footnotetext{
${ }^{14}$ Língua semítica aparentada do hebraico. Na Antiguidade, o aramaico foi falado por todo Oriente Próximo, e tornou-se parte integrante da cultura linguística judaica. Existe mesmo uma versão talmúdica, segundo a qual Adão falava aramaico. Diferentes dialetos do aramaico, representando formas palestinas e babilônicas, são encontrados na literatura judaica. Grandes seções da Bíblia, como os livros de Daniel e Esdras, são em aramaico. (UNTERMAN, A. Dicionário Judaico, 1994, p.29)

${ }^{15}$ Escola primária.

${ }^{16}$ Moses Montefiore (1784-1885), inglês com ascendência judaica, foi presidente do Board of Deputies de 1835 a 1874 e era amigo pessoal da rainha Vitória. Sua impressionante figura e extraordinária generosidade com judeus e gentios fizeram dele o último grande representante da comunidade judaica europeia. Sob a liderança vigorosa de Montefiore, os judeus ingleses passaram a ser uma espécie de porta-voz de todos os judeus da
} 
publicação de Joseph foi sua dissertação de mestrado sobre o Talmud e o divórcio, na qual ele deu uma conotação erudita à visão da lei judaica. Sua pesquisa era inédita por dar visibilidade a esse tema místico e utilizar fontes literárias alemãs e hebraicas. (Lifton, 2005, p. 368). Os irmãos Goldszmit também foram autores de vários artigos sobre a necessidade de secularizar e atualizar as instituições de ensino e orfanatos judaicos.

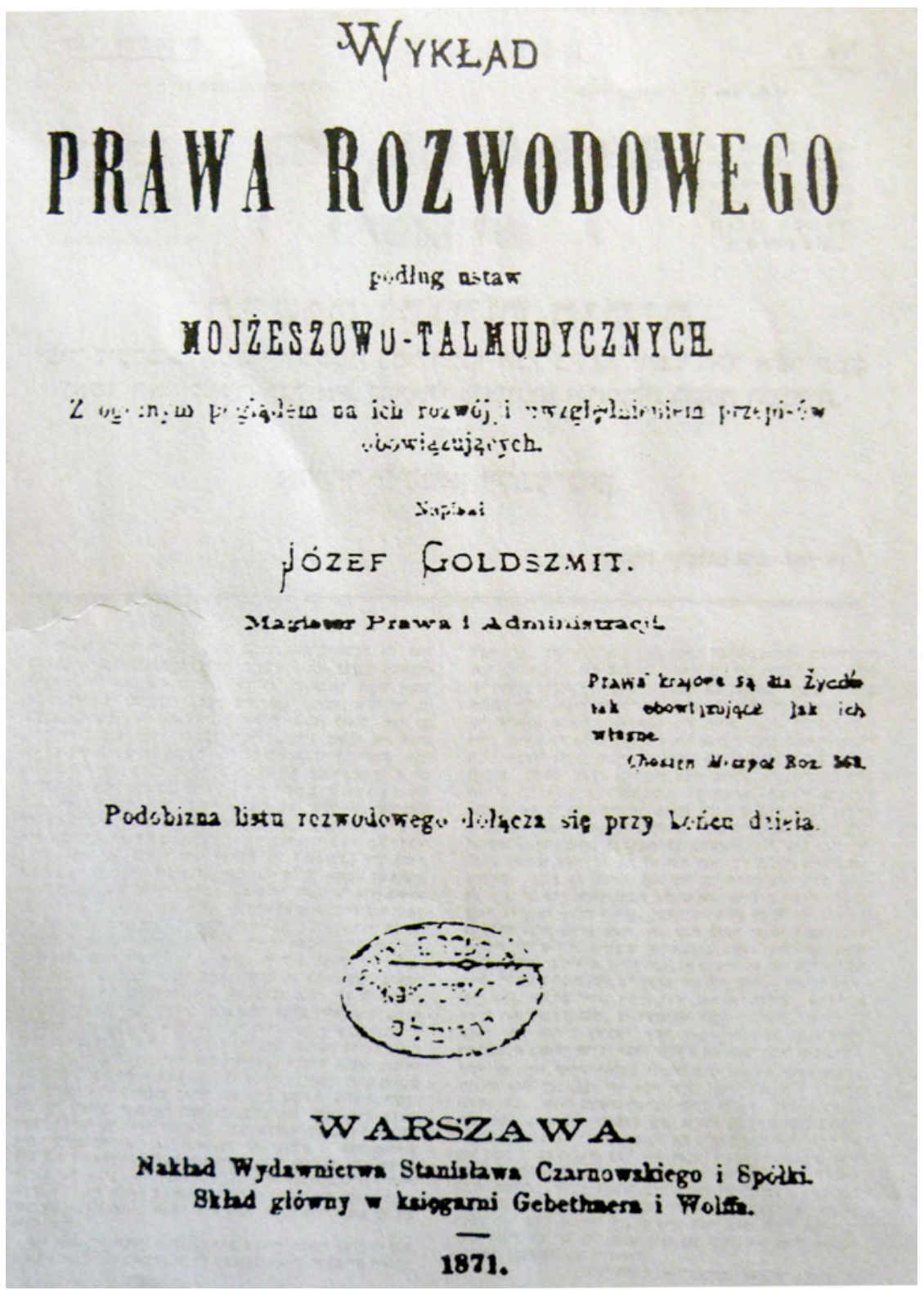

Imagem 02 - Página de rosto do livro Talmud e o Divórcio de Joseph Goldszmit. Fonte: EDEN, 2000, p. 240.

Europa. Ao completar um incomum centenário, em 1884, um ano antes de sua morte, Moses Montefiore foi efusivamente celebrado no mundo inteiro. (BORGER, 2002, p.337). 
Em 1874, Joseph, conhecido por sua especialização nas leis do divórcio, foi convidado a proferir palestras sobre as leis matrimoniais em Kalisz, uma antiga cidade industrial no lado ocidental da Polônia. Provavelmente foi quando conheceu sua esposa Cecylia Gebicka, filha de Adolph Gebicki, um industrial de sucesso que circulava nos meios judaicos e poloneses (idem, p.369). Dessa união nasceram dois filhos: Henryk e Anna. Cecylia, a mãe de Henryk, neta de médico, foi criada pelos pais dentro dos moldes da Haskalá, à semelhança de Joseph, seu marido.

\subsection{De Henryk Goldszmit a Janusz Korczak}

O filho de Joseph e Cecília, Henryk Goldszmit, nasceu em Varsóvia no dia 22 de julho de 1878, ${ }^{17}$ quando a Polônia se encontrava sob domínio russo. Ele foi educado por tutores dentro do próprio lar até os sete anos, como era costume em alguns círculos restritos. Em seguida foi estudar na escola russa elementar, onde era proibido estudar a história e a

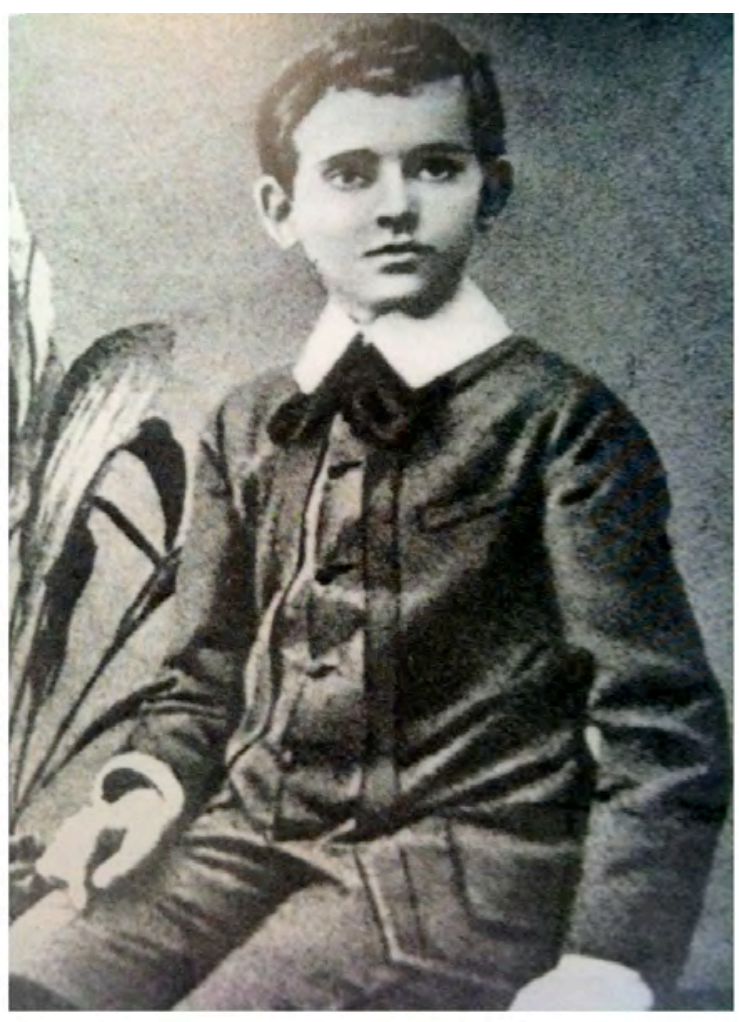

Imagem 03 - A criança Henryk Goldszmit (Korczak) com aproximadamente 10 anos. Fonte: Beit Lohamei Haghetaot língua polonesa. O sistema de educação nas escolas era autoritário e punitivo e permitia que os alunos sofressem periodicamente agressões físicas, como puxões de orelha ou espancamentos com a régua pelo professor.

Henryk morava numa casa grande em umas das ruas mais nobres de Varsóvia. Seu lar era constituído, em sua maioria, por mulheres: a mãe, a irmã menor, a avó materna, a cozinheira, a arrumadeira e a babá (PERLIS, 1986, p.9).

Henryk e sua irmã Anna eram proibidos de brincar na rua, pois a mãe não considerava esse comportamento adequado para crianças educadas e de bons modos. Trancado em sua casa, Henryk ficava horas

\footnotetext{
${ }^{17}$ De acordo com Perlis (1986), há uma dúvida a respeito do ano de nascimento identificada na ficha da SS de inscrição preenchida por Korczak para dar entrada ao Gueto de Varsóvia em 1940. Segundo Lifton (1997), foi o pai de Korczak que registrou propositadamente o filho um ano após seu nascimento, pois era comum atrasar o registro para adiar o futuro alistamento militar.
} 
brincando com seus cubos de brinquedo ou apreciando pela janela a liberdade das crianças brincando no pátio. O que seus pais não sabiam era que Henryk com seu brinquedo de cubos estava construindo as torres que no futuro iriam aparecer em seu livro $O$ Rei Mateuzinho I, escrito em $1922 .^{18}$

Eu era uma criança que "pode brincar horas a fio sozinha", a criança que "nem sabe se está em casa". Recebi os meus primeiros cubos aos seis anos e deixei de brincar com eles ao quatorze. "Como, você não tem vergonha? Um rapaz da sua idade? Faça alguma coisa... leia. Mas os cubos, que coisa!” Aos quinze anos fui tomado de uma fúria de leitura. Não vi mais nada, só existiam livros. (KORCZAK, 1986, p.9)

De sua avó, Henryk recebia o carinho e o suporte de que necessitava e com ela dividia os sonhos e revelava os pensamentos. Ela faleceu quando ele tinha quatorze anos e a família passava por momentos difíceis devido à instabilidade emocional de seu pai. A desestabilização familiar ocasionada pela ausência do pai, que foi internado várias vezes num sanatório, fez com que Henryk mergulhasse no mundo da imaginação e buscasse consolo no túmulo da sua avó materna no cemitério judaico. Aos cinco anos, confidenciou seus pensamentos à avó:

Papai tinha razão quando me chamou de boboca ou de simplório ou mesmo, nos momentos particularmente tempestuosos, de imbecil ou de burro. A vovó era a única a acreditar na minha boa estrela. Senão era sempre "preguiçoso", "chorão" (já o disse), "idiota", "imprestável". Mas teremos tempo de falar disto ainda. Eles tinham razão, os dois. Vovó e papai. Cada um pela metade. Voltaremos a falar disto. Preguiçoso... Isto confere. Não gosto de escrever. Pensar sim. Isto não me causa dificuldade. É como se contasse histórias a mim mesmo. [...] Vovó "dizia quando me dava uvas passas: - Meu filósofo.” (KORCZAK, 1986, p.11)

E:

Parece que a esta altura já a iniciei, numa conversa a dois, no meu audacioso projeto, visando à transformação do mundo. Era preciso jogar fora todo o dinheiro. Nem mais nem menos. Como e onde jogar, o que fazer dele em seguida, eu não devia, sem dúvida, saber. Tinha então só cinco anos e o problema era de uma gravidade incômoda: o que fazer para que não existam mais crianças sujas, esfarrapadas, esfomeadas, com quem não se tinha o direito de brincar no pátio onde, sob a castanheira, em uma ex-caixa de

\footnotetext{
${ }^{18}$ Fábula infantil publicada em 1928, em que Korczak conta a história de um príncipe que, ainda menino, após a morte dos pais, se torna rei. Na condição de rei, não pode mais ter um comportamento infantil e fica, de sua janela, admirando as crianças brincar livremente pelo jardim. No seu reinado, dispõe-se a reformar o reino em benefício das crianças e dos adultos. Travando batalhas corajosas contra as injustiças, depara-se com sua inexperiência e ingenuidade. Sob a ótica de uma criança, o enredo da história revela as várias decepções sofridas pelo rei Mateuzinho ao confiar nos adultos.
} 
bombom de ferro, repousava o primeiro morto entre meus próximos, e bemamado amigo: o canário. Sua morte me revelou a existência do misterioso problema da confissão. (idem, p.12)

O primeiro contato com a sua judeidade ocorreu na idade de cinco anos, durante o episódio da morte de seu canário. O que ocorreu ao menino na sequência do evento o fez entender que ele, como judeu, seria sempre considerado inferior a quem era católico. A confissão relatada acima é decorrente da revelação de sua religião por outra criança, acidentalmente trazendo à tona, pela primeira vez, o dilema de ser judeu num país católico ${ }^{19}$.

Eu quis colocar uma cruz no túmulo. A empregada disse que não, porque era um pássaro, portanto bem inferior ao homem. Chorá-lo já era um pecado. Eis aí a empregada. Mas o que o filho do zelador disse era bem pior: o canário era judeu. E eu também. Eu era judeu e ele, polonês e católico. Ele estará um dia no paraíso; quanto a mim, com a condição de nunca pronunciar palavras feias e levar-lhe docilmente açúcar furtado em casa, poderei entrar, após a minha morte, em alguma coisa que não propriamente o inferno, mas onde, de toda forma, é muito escuro. E eu tive medo do escuro. A morte - judeu - o inferno. O escuro paraíso judeu. Dava o que pensar. (KORCZAK, 1986, p.12)

Henryk foi transferido para o ginásio russo, localizado em um subúrbio de Varsóvia, na margem direita do rio Vístula. Não era mais uma escola de elite, já que os recursos financeiros da família haviam sido direcionados para o tratamento psiquiátrico do pai. No Diário do Gueto (1986), Korczak, que leu os clássicos da literatura polonesa e universal, escreveu que a leitura foi um alento, nessa fase da vida, ele se refugiava na leitura e em composições literárias, como as Confissões de uma Borboleta (KORCZAK, 1999, pp.133217), texto romântico publicado em 1914, com estrutura de diário pessoal:

Eu sou uma borboleta bêbada com a vida. Eu não sei onde subir, mas não permitirei que a vida prenda minhas asas coloridas. (KORCZAK, 1999, p.188)

Em 1896, após a morte prematura do pai aos 52 anos, por suspeita de suicídio, Henryk foi obrigado a ajudar financeiramente no sustento da casa, passando a dar aulas

\footnotetext{
${ }^{19}$ Fundada como um reino cristão em meados do século X, a Polônia foi constituída de dois grupos étnicos distintos: germanos e eslavos. Os germanos, a oeste, convertidos à fé luterana no século XVI, e os eslavos, cristãos ortodoxos, a leste. Firmaram-se, então, como os mais fervorosos seguidores do catolicismo do leste europeu, situação que, com o tempo, provocou a simbiose entre a nacionalidade e a religião: Um verdadeiro polonês é católico. (LIFTON, 2005, p.8).
} 
particulares. Descobriu que gostava de ensinar às crianças e tinha facilidade para isso. A perda lenta e trágica do pai foi um trauma que Korczak trouxe consigo por quase toda vida, conforme está escrito em seu livro Diário do gueto (1986, p.103):

\begin{abstract}
A minha vida foi difícil, mas interessante. É o tipo de vida que pedi a Deus na minha mocidade: "Meu Deus, conceda-me uma vida dura, mas bela, rica e elevada". Quando soube que Slowacki já era autor da mesma oração, sofri; assim a ideia não era minha, eu tive um predecessor. Na idade de dezessete anos comecei a odiar a vida de medo de enlouquecer. Tive medo que parecia pânico do hospital psiquiátrico onde meu pai foi varias vezes internado. Filho de um alienado, eu era, pois, portador de uma tara hereditária. Durante dezenas de anos esta ideia voltou a me atormentar periodicamente e me atormenta até hoje. Mas eu gosto demais da minha loucura para não ficar apavorado ante a ideia de que alguém queira curar-me contra a minha vontade.
\end{abstract}

\title{
1.3. Formação e atuação voluntária e profissional
}

Entre a escola e o trabalho Henryk tinha pouco tempo para si e escreveu em seu diário, publicado posteriormente com o título de Confissões de uma Borboleta (1914), que ele não aspirava a ser escritor, mas desejava ser médico. Sua justificativa era que a literatura era apenas palavras enquanto a medicina era ação. Mesmo assim, escreveu textos sobre o público infantil, que posteriormente foram publicados no semanário Thorns. ${ }^{20}$ Em 1898, ingressou na Universidade de Medicina de Varsóvia, um privilégio conquistado por um círculo restrito de judeus devido às leis antissemitas. Havia $\operatorname{cotas}^{21}$ para o ingresso de judeus nas faculdades, e, segundo Claudie Weill (2010, p.212), a questão do ingresso dos jovens judeus poloneses em liceus e universidades era uma das novas iniciativas em resposta à Haskalá, pois, para participar da sociedade, era necessário ter formação em carreiras como Medicina, Direito, entre outras.

Na Universidade, Henryk passou a ser conhecido pelo pseudônimo de Janusz Korczak. Goldszmit escolheu este pseudônimo aos vinte anos, quando se inscreveu num concurso literário com uma peça teatral intitulada: "Que caminho?”. De acordo com Lifton (2005, p.31-32), a opção do nome, originalmente Janasz Korczak, não foi aleatória ${ }^{22}$. Seu tio, Jakub Godszmit, presenteou-o com o livro do famoso novelista polonês, Joseph Ignacy

\footnotetext{
${ }^{20}$ A coluna no semanário polonês Thorns foi o primeiro emprego fixo de Korczak.

${ }^{21}$ A legislação anti-judaica nas chamadas Leis de Maio, decretada pelos czares em maio de 1882, determinava aos judeus uma cota limitada de ingresso nas universidades - numerus clausus. Apenas os judeus que habitavam as grandes cidades como Varsóvia, Moscou e S. Petersburgo puderam freqüentar estas instituições.

${ }^{22} \mathrm{Na}$ impressão foi editado Janusz no lugar de Janasz e Korczak adotou o nome com a grafia errada. in (LIFTON,2005, p.31)
} 
Kraszewski, nascido em 1812, seu amigo. No livro, o personagem Janasz Korczak era um herói órfão, corajoso e de origem nobre. A escolha do pseudônimo pode ter acontecido por duas razões. A primeira para preservar o anonimato da família e possivelmente mudar sua sorte $^{23}$, e a segunda para garantir um nome polonês. Num país em que se rejeitava a origem judaica dos cidadãos, o sobrenome Goldszmit era indiscutivelmente um nome judaico e discriminado. Com um nome gentio ele poderia se recriar como um cidadão comum ligado a um passado heroico como o de qualquer polonês.

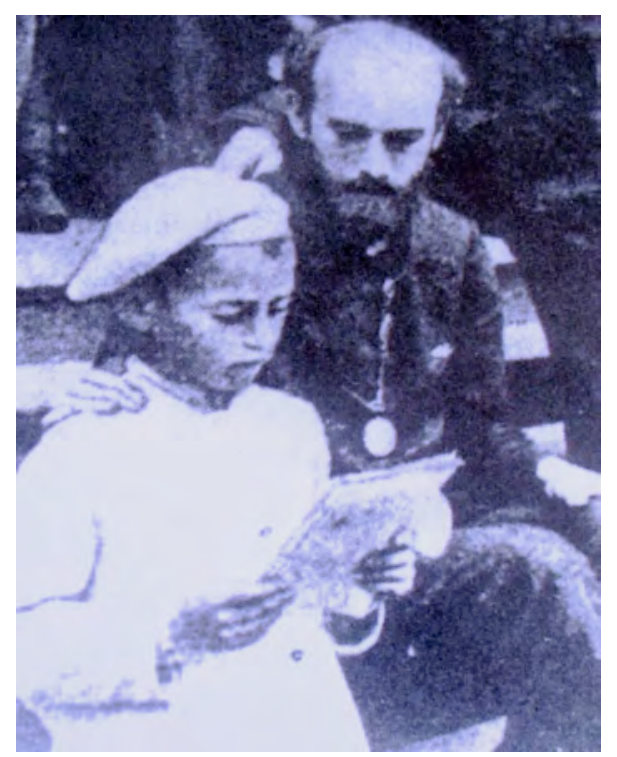

Imagem 04 - Korczak em 1907 em uma colônia de férias. Fonte: LIFTON, 2005, p. 188.

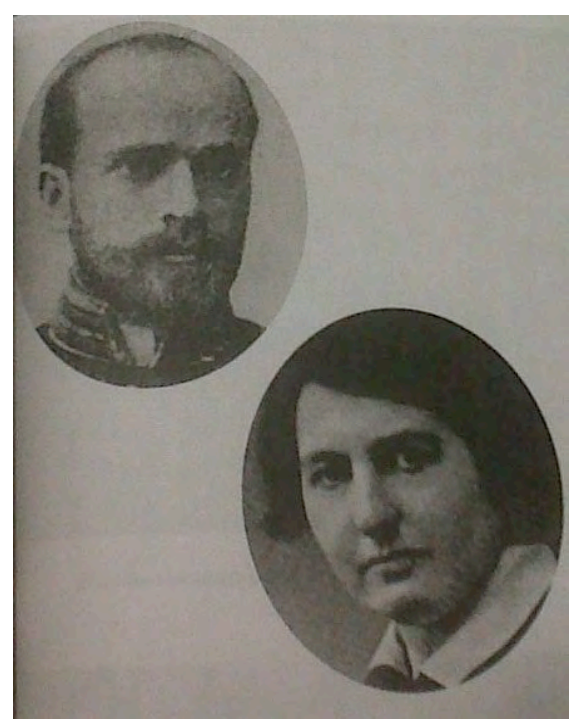

Imagem 05 - Korczak e Stefa em 1909. Fonte: LIFTON, 2005, p. 189.

\footnotetext{
${ }^{23}$ Korczak carregava o peso da doença emocional do pai e do seu suposto suicídio.
} 
Mesmo não vencendo o concurso, Korczak não desistiu de continuar escrevendo, e passou a trabalhar como colaborador de um semanário cômico chamado Kolce (PERLIS, 1990). Formou-se em Medicina e continuou escrevendo artigos sobre a criança. Durante sua vida, ele escreveu vários livros para o público infantil e adulto, alguns deles traduzidos para a língua portuguesa, tais como: $O$ Rei Mateusinho $I^{24}$, Quando eu voltar a ser criança ${ }^{25}$ e Como amar uma criança ${ }^{26}$, A sós com Deus (2007) e Diário do Gueto (1986), em que apresentou suas ideias sobre os direitos da criança e da educação democrática, trazendo novas concepções para o desenvolvimento da capacidade de raciocínio e espírito crítico do aluno.

Seus estudos durante a universidade voltaram-se à saúde das crianças, formando-se em pediatria. No ano de 1908, Korczak viajou a Berlim e Zurique para estudar mais sobre o comportamento infantil em cursos de especialização na área pedagógica, mas atrasou sua

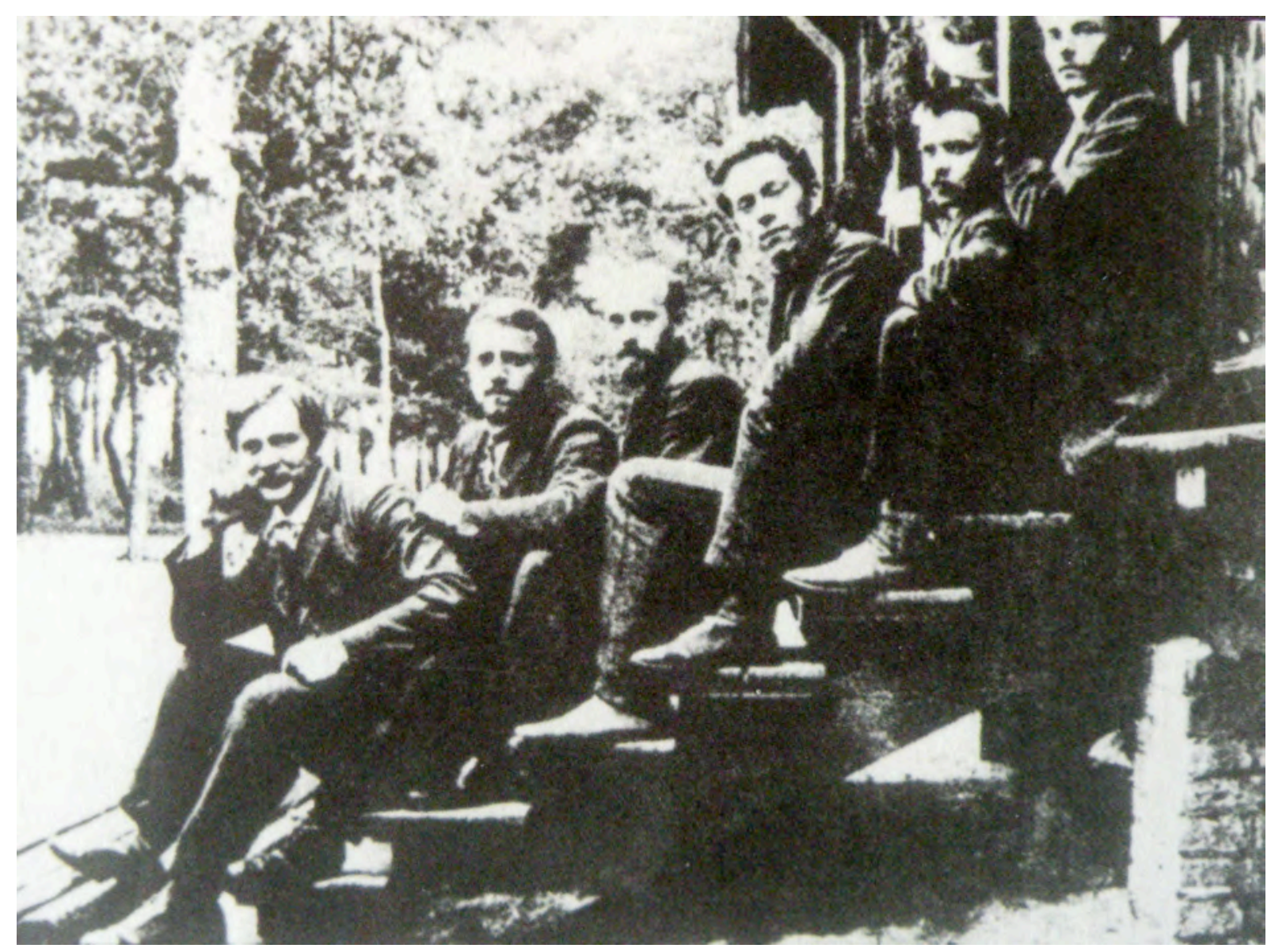

Imagem 06 - Korczak (terceiro da esquerda para a direita) em 1908 com os colegas da Faculdade de Medicina. Fonte: Beit Lohamei Haghetaot

\footnotetext{
${ }^{24}$ Rei Mateusinho I foi publicado, pela primeira vez, em 1923.

${ }^{25}$ A edição original de Quando eu voltar a ser criança é de 1925.

${ }^{26}$ A primeira parte desta obra - A Criança na sua Família foi originalmente publicada em 1919. A primeira edição completa de Como amar uma criança é de 1920.
} 
graduação em função de sua atividade extracurricular jornalística e das horas obrigatórias de treinamento militar.

De acordo com Lifton (2005, p.371), Korczak publicou centenas de artigos e folhetins entre os anos de 1896 e 1907, da idade de dezoito aos vinte e sete anos, em dezenas de jornais judaicos e poloneses. No livro Crianças de Rua (1901), Korczak retratou seus encontros com as crianças pobres e carentes de Varsóvia enfatizando sua crença na possibilidade de recuperação por meio da educação nos primeiros anos da infância. Por intermédio do editor do jornal Glos freqüentou a Flyng University, a faculdade clandestina de Varsóvia onde os jovens patriotas se encontravam para estudar e reivindicar a liberdade da Polônia sob domínio russo. Korczak participou do espírito revolucionário, assim como muitos jovens de sua geração; porém nunca se filiou a nenhum partido político, partindo da premissa de que só pela da educação era possível desenvolver uma sociedade melhor. A Polônia passava por uma transição de uma sociedade agrária para a industrial e rapidamente foram construídas novas fábricas. Dezenas de milhares de camponeses migraram para as cidades à procura de emprego, mas a maioria ficou desempregada e desabrigada, criando uma nova população pobre em Varsóvia (LIFTON, 2005, p.33).

Korczak se envolveu com o problema das crianças de rua que aumentaram neste período e que não possuíam representantes para lutar por seus direitos. As ruas pobres de Varsóvia se encheram de jovens médicos, como ele, dispostos a ouvir e ajudar esse proletariado carente.

Foi na Flying University que Korczak entrou em contato com as ideias inovadoras na área da educação, ideias que libertavam as crianças das restrições convencionais do passado. De acordo com Marangon (2007), o mundo das crianças era separado do mundo dos adultos. As crianças eram classificadas como não-letradas e, portanto não participavam da vida dos letrados. Foi só a partir dos séculos XVI e XVII que a infância começou a ser reconhecida e respeitada passando a ser essencial que as crianças aprendessem a ler.

Dois autores influenciaram a prática educativa de Korczak: Jean Jacques Rousseau ${ }^{27}$ (1712-1778) e Johann Pestalozzi ${ }^{28}$ (1746-1827). Com as ideias de Rousseau, Korczak aprendeu sobre os avanços pedagógicos em relação ao desenvolvimento natural da criança. Com Pestalozzi, ele entendeu e aplicou, no seu cotidiano no orfanato, as ideias da educação

\footnotetext{
${ }^{27}$ Um dos principais filósofos suiços do Iluminismo.

${ }^{28}$ Pedagogo suiço que, assim como Rousseau, se distinguiu pelo filantropismo, atendendo as populações carentes.
} 
democrática. Segundo Singer, (2010, p.76) Korczak acreditava na "bondade natural" da criança e na necessidade de se respeitar sua personalidade.

Korczak trabalhou voluntariamente durante anos no programa assistencial gratuito dirigido ao público infantil em que, em algumas bibliotecas, uma vez por semana, se contavam histórias às crianças carentes. O projeto consistia em estimular a leitura e os empréstimos dos livros. Esse trabalho em conjunto com voluntários poloneses e judeus foi para Korczak um rico material de atuação e observação sobre as crianças ${ }^{29}$.

Após graduar-se em 1904, iniciou a residência no Hospital Público Judaico Infantil e no ano seguinte, foi convocado pelo Exército Imperial Russo para servir na guerra russojaponesa (1904-1905) ${ }^{30}$ num trem-hospital na ferrovia Transiberiana. Durante a guerra ainda encontrava tempo para escrever artigos sobre a criança e dar notícias sobre a guerra para sua coluna na revista Glos. Ao retornar a Varsóvia, Henryk constatou que seus artigos haviam sido amplamente recebidos pelo público, consagrando-o como "Janusz Korczak, o novo escritor jovem da literatura de Varsóvia". Esses artigos foram incluídos no seu livro Crianças de Salão (1906).

Por outro lado, após o fracasso da Rússia na guerra, as escolas de Varsóvia voltaram a ensinar em língua polonesa. A universidade clandestina tornou-se oficial com o nome de Sociedade dos Cursos Científicos e, posteriormente, Universidade Livre da Polônia. Esta conquista se deu por causa da interrupção temporária da lei referente ao numerus clausus entre os anos de 1905 e 1908 (TURNIANSKY, 2010, p. 212).

Em 1906, Korczak retornou ao seu cargo de médico-residente no Hospital Judaico Infantil, onde permaneceu trabalhando por sete anos. Este hospital atendia gratuitamente todas as crianças doentes, independente de religião. Diferentemente do que acontecia com a maioria dos médicos judeus, Korczak possuía pacientes poloneses particulares pertencentes às famílias proeminentes de Varsóvia, ao mesmo tempo em que se disponibilizava para atender

\footnotetext{
29 The Free Lending Library, A Sociedade Beneficente para Bilbiotecas de Empréstimos Gratuitos.

${ }^{30}$ Entre 1894 e 1917 o Império Russo passou por uma grave crise política. Durante esse período, a expansão russa para leste abriu o caminho para um conflito contra o Japão em 1905, e o desempenho desastroso das forças armadas russas na guerra russo-japonesa configurou-se como uma das principais causas de um movimento espontâneo e anti governamental conhecido como "Revolução de 1905". (BORGER, 2002, p.374). O governo incentivou a propaganda antissemita com a publicação de Os protocolos dos sábios de Sião, que encorajou mais tumultos, resultando nos pogroms de 1903 a 1906 e que motivaram uma grande emigração de judeus para a Europa Ocidental, América do Sul, África do Sul, Palestina e principalmente Estados Unidos. Isso é uma continuação ou uma outra nota? A referência de Borger não engloba esta informação?
} 
as famílias carentes por um valor irrisório. Korczak acreditava na premissa do Talmude ${ }^{31}$ que ensina aos médicos que se deve cobrar, mesmo que pouco, para valorizar o próprio trabalho. (Korczak, 1986, p.69)

O sonho de ajudar as crianças pobres levou Korczak a participar, como monitor, de colônias de férias infantis. Depois de 1907, viajou com crianças judias e polonesas pobres. As viagens eram promovidas e custeadas por filantropos que se preocupavam em dar a oportunidade para que cento e cinquenta crianças carentes pudessem divertir-se nas férias escolares.

As crianças eram, em sua maioria, provenientes de lares desestruturados e com pais alcoólatras. Este trabalho proporcionou a Korczak a oportunidade de integrar crianças polonesas e judias por um breve período de tempo e de conhecer o desenvolvimento e a saúde das crianças fora do hospital. Foi nesta época que escreveu a obra sobre a criança judia: Moski, Joski, Srule (1910) e sobre a criança polonesa Joski, Jaski e Franki (1911). Baseados nesses ensaios, Korczak concluiu que a maioria das crianças tinha os mesmos anseios, medos e desejos, independentemente de sua religião.

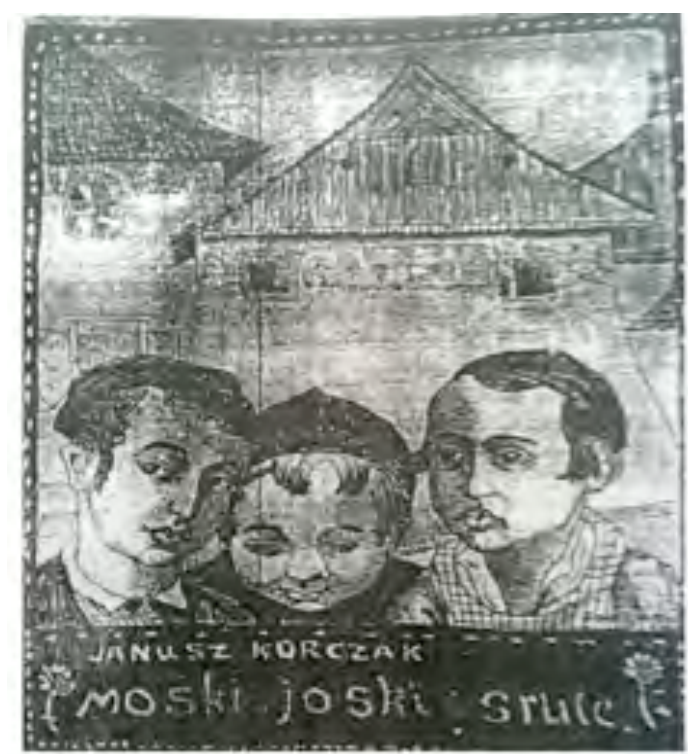

Imagem 07 - Capa do livro de Korczak Moski, Joski e Sruli. Fonte: EDEN, 2000, p. 160.

\footnotetext{
31 Talmud, também conhecido como a Torá Oral. Steinsaltz (1989, p. 3-53) caracteriza o Talmud como o repertório de milhares de anos de sabedoria judaica, um compêndio de lei, lenda e filosofia, um misto de lógica singular e penetrante pragmatismo, de história e ciência, anedotas e humor. In Spiczkowski, Educação e Talmud, uma releitura da Ética dos Pais. São Paulo, Perspectiva, 2002, p.32.
} 
Quando, em 1908, seu colega de hospital Dr Izaak Eliasberg ${ }^{32}$ lhe contou a respeito da Sociedade Judaica de Ajuda aos Órfãos onde trabalhava com a esposa, Korczak encontrou um novo propósito para a vida: não seria mais apenas um médico, mas também um educador. A instituição estava nessa época angariando fundos para a manutenção de um abrigo para crianças órfãs e abandonadas e Korczak foi convidado a ajudar na arrecadação de donativos para esse projeto. Encontrou, no abrigo, a educadora Stefania Wilczynska (LIFTON, 2005, p.135) ${ }^{33}$, mais conhecida como Stefa, que dirigia a instituição: foi o começo de uma amizade que durou até o final de suas vidas, em Treblinka. Stefa era formada em Ciências Naturais na Universidade Belga de Liège. Oito anos mais jovem que Korczak, tinha a educação como interesse e, ao retornar a Varsóvia, trabalhou voluntariamente no abrigo para crianças e, posteriormente, junto com Korczak, no Orfanato Don Sierot, na Rua Krochmalna até 1942.

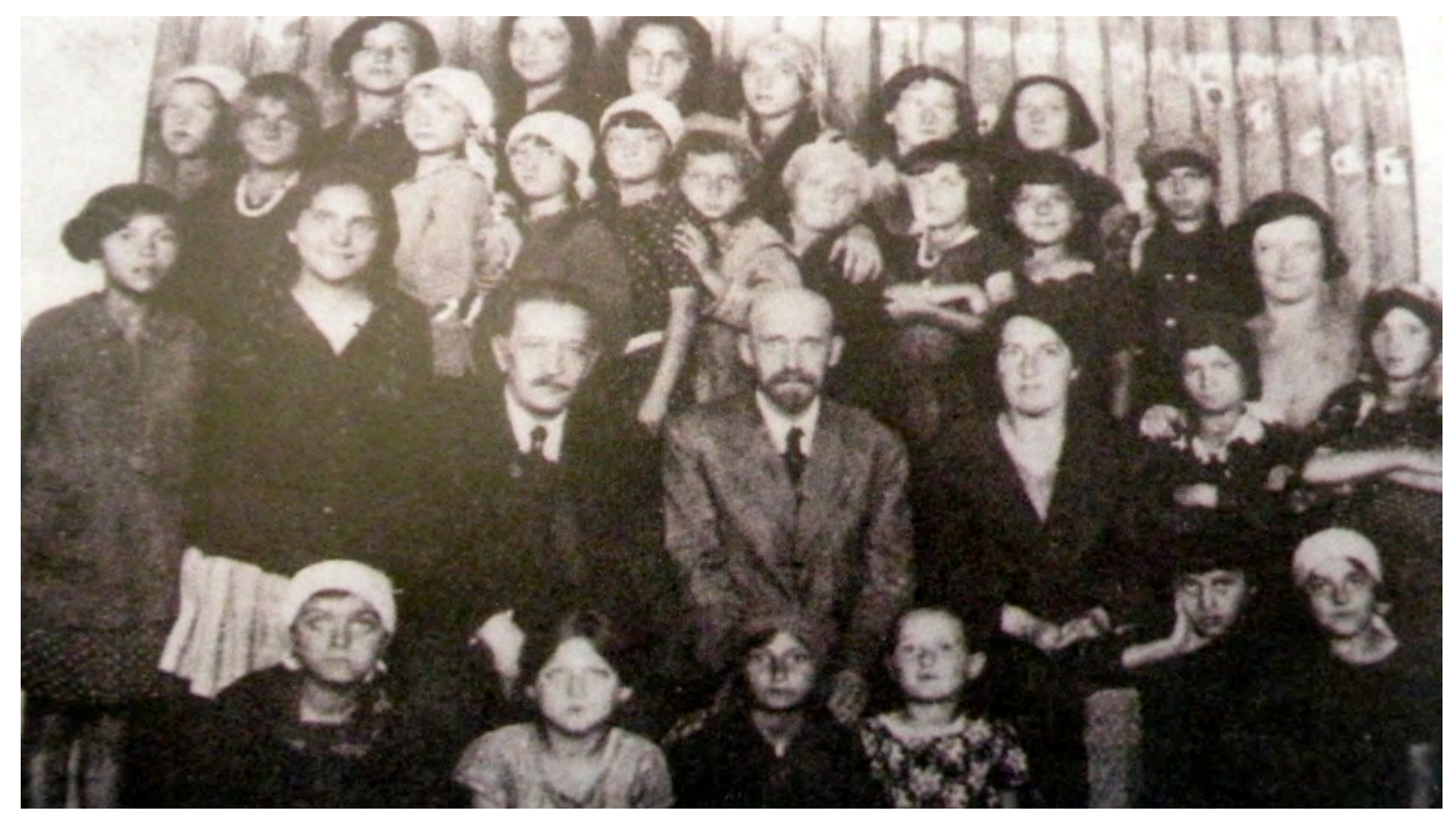

Imagem 08 - Korczak ao centro, à esquerda Dr. Eliasberg e a direita Stefa Wilczynska no orfanato Don Sierot em 1923. Fonte: Revista Morashá, ano XVI, dez/2008-nº3, p. 25

\footnotetext{
${ }^{32}$ Izaak Eliasberg (1860-1929) foi médico e ativista social e presidente da Sociedade Judaica de Ajuda aos Órfãos de Varsóvia.

${ }^{33}$ Segundo Perlis, Korczak já havia conhecido Stefa em Zurique em 1908 quando ambos estudavam a pedagogia de Maria Montessori, porém há controvérsias.
} 
Em 1909, a situação política da Polônia entrou mais uma vez em crise por causa da volta da repressão czarista. As universidades foram fechadas e milhares de intelectuais, socialistas e membros do partido revolucionário foram aprisionados ou mandados para a Sibéria. A editora das revistas para a qual Korczak trabalhava foi fechada, e ele foi enviado à prisão de Spokonja, junto com outros escritores. Foi libertado com a ajuda de uma família polonesa rica e influente, cujo filho fora paciente de Korczak.

\title{
1.4. De médico a diretor de orfanato
}

Mais uma vez, o casal Eliasberg foi responsável por apresentar a Korczak um novo projeto. A ideia consistia na construção de um orfanato modelo, uma vez que o abrigo para crianças órfãs e abandonadas era pequeno diante da enorme demanda por vagas neste tipo de estabelecimento após o fim da guerra russo-japonesa. Em 1910, Korczak e Stefa foram convidados para a realização de um sonho comum: a construção de um ambiente educacional digno das crianças. O novo projeto representou a transição profissional de Korczak: de médico no hospital judaico infantil a diretor do Orfanato Don Sierot, decisão que se tornou para ele um fato a lamentar :

\begin{abstract}
Abandonei o hospital pelo Orfanato. Guardo sentimento de culpa. Saí a primeira vez por imposição (a guerra). Uma segunda vez, por um ano (Berlim). Uma terceira vez, apenas por seis meses (Paris). Para as luzes, para o saber. E depois, no momento quando já sabia que não sabia nada e porque não sabia nada, quando, enfim, eu podia não causar mal ao doente, eis que largo para o desconhecido. O hospital me deu tanto e eu, ingrato, dei-lhe tão pouco. Que deserção vill! A vida me castigou por isto. (KORCZAK, 1986, p.71)
\end{abstract}

Como diretor do orfanato, Korczak idealizou e planejou juntamente com dois arquitetos, a construção de um modelo moderno de arquitetura escolar. Quando foi inaugurado, em 1912, o "Lar das Crianças" [Don Sierot] chegou a abrigar 150 crianças entre 7 e 14 aos de idade. O orfanato localizava-se na Rua Krochmalna, $n^{\circ} 92$, numa vizinhança que durante séculos abrigava judeus e poloneses. Isaac Bashevis Singer, que viveu no $\mathrm{n}^{\circ} 10$ dessa rua, descreve essa pitoresca ocupação em Shosha:

Esta rua era como uma camada profunda de uma escavação arqueológica que eu jamais traria à tona. Ao mesmo tempo, lembrava-me de cada casa pátio, heder [escola primária], casa de estudo hassídica, loja, cada garota, vagabundo de rua, donas de casa - suas vozes, gestos, maneiras de falar, suas peculiaridades. (BASHEVIS SINGER, 1978, pág. 22) 
Retomando a questão biográfica, Korczak aspirava a um orfanato que funcionasse como uma comunidade democrática em que os jovens pudessem constituir seu parlamento, tribunal e jornal e que, dentro de um processo de trabalho grupal, as crianças tivessem a oportunidade de conviver com o próximo, com honestidade e responsabilidade.

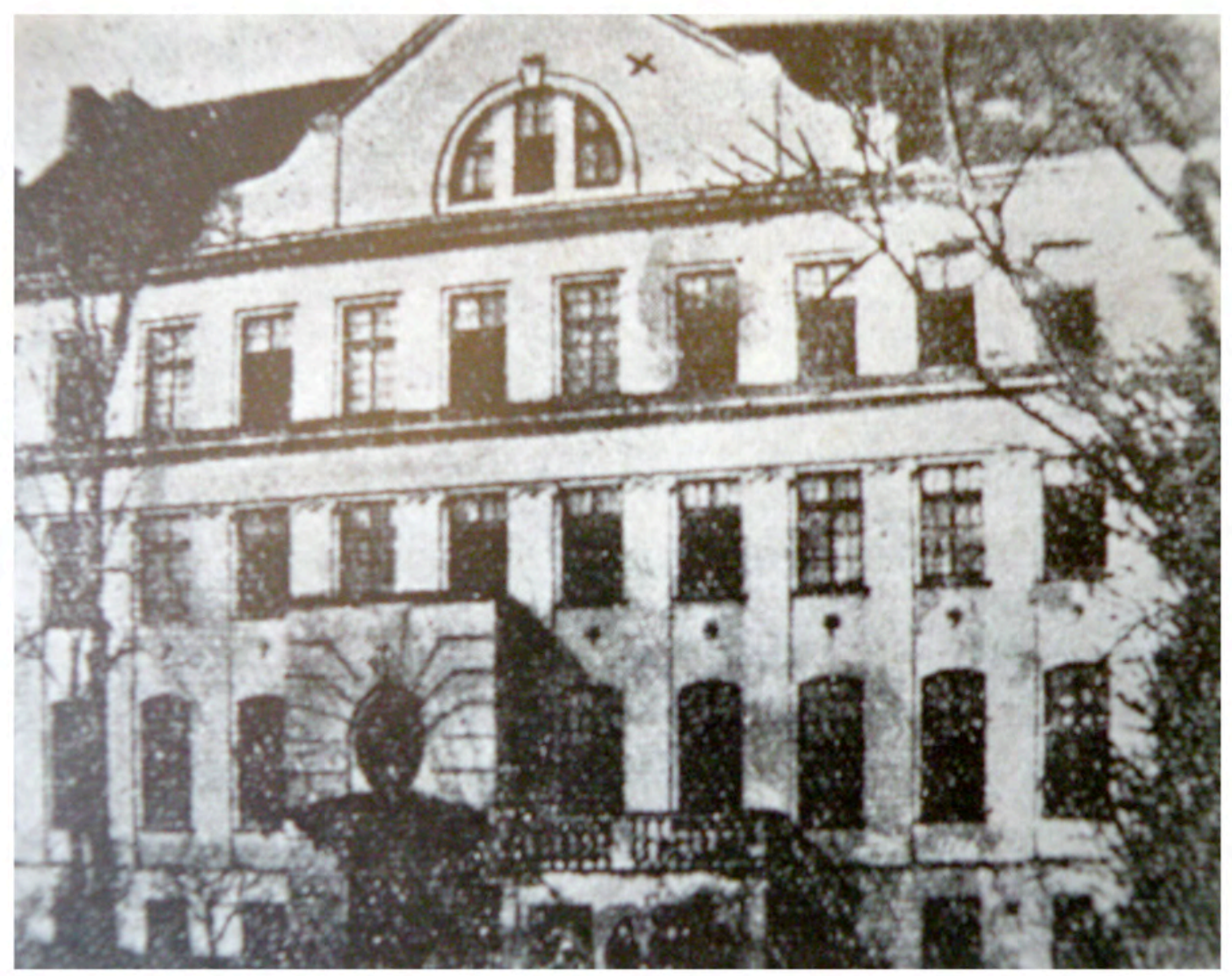

Imagem 09 - Orfanato da Rua Krochmalna, 92 - Don Sierot. Fonte: KORCZAK, 1972, p. 177.

Durante o período de construção do orfanato, em 1910, Korczak viajou por seis meses a Paris para participar de cursos com especialistas pediátricos e para conhecer orfanatos e casas de detenção. No ano seguinte viajou a Londres, para visitar uma instituição para órfãos localizada em Forest Hill (LIFTON, 2005, p.65), onde aprendeu parte das estratégias pedagógicas que aplicou no orfanato de Varsóvia.

O orfanato foi inaugurado em outubro de 1912, sendo uma das primeiras instituições desse tipo que possuía instalações modernas, com aquecimento central, dois grandes dormitórios para meninos e meninas, grandes janelas, sala de refeição, sala de estudo, área de lazer, banheiros com água quente e uma moderna e bem equipada cozinha. Lá desenvolveu 
um modelo de autogestão, no qual as próprias crianças eram responsáveis por atividades que envolviam a administração e a convivência social, o que favorecia a autonomia de pensamento e de sentimentos e a iniciativa na tomada de decisões. No orfanato, Korczak foi o responsável pela introdução de elementos que possibilitavam a convivência democrática tais como: o quadro de avisos, a caixa de cartas, a vitrina dos objetos achados, a divisão do trabalho, o comitê de tutela, as reuniões-debate, o jornal, o tribunal de arbitragem, cujos juízes e demais membros eram facilitadores da ação democrática implantada no cotidiano das crianças.
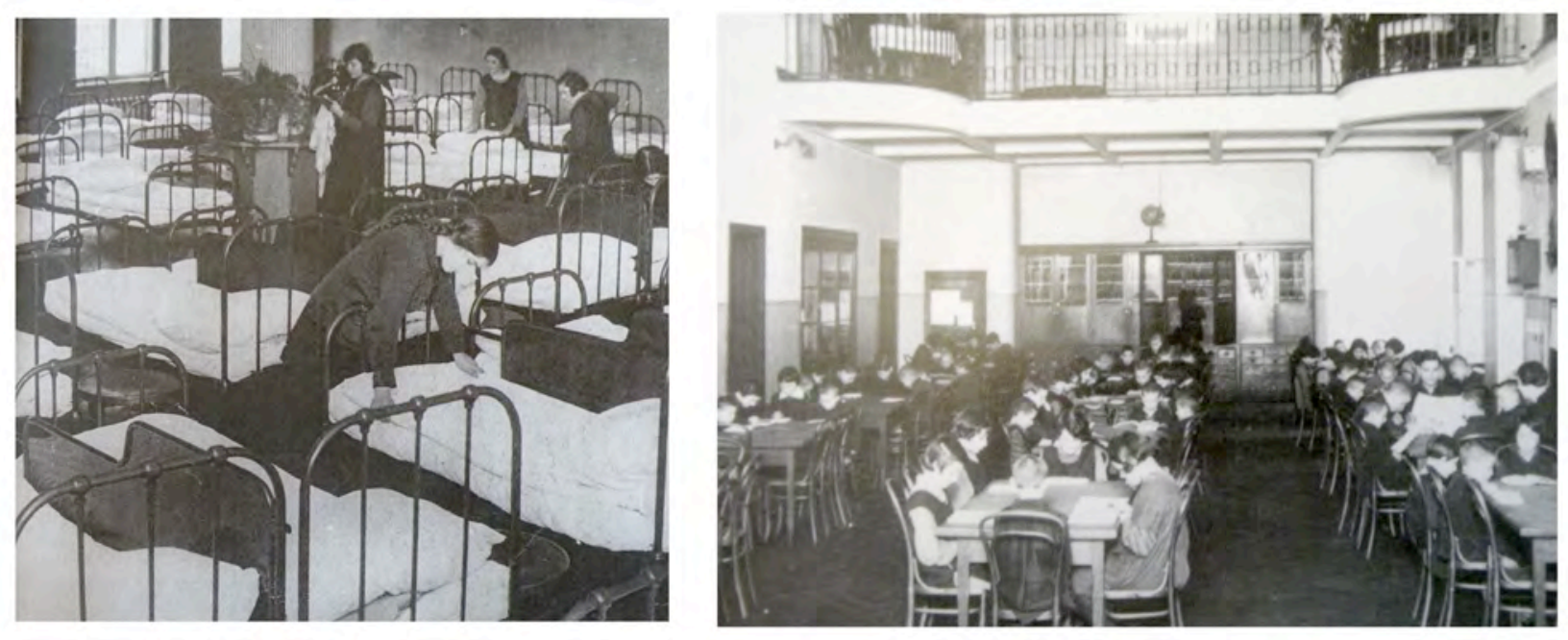

Imagem 10 - Refeitório e dormitório do orfanato Don Sierot em 1929. Fonte: Beit Lohamei Haghetaot.

O sistema de autogestão objetivava dar emancipação à criança e lhe outorgar seus direitos. Criou-se um tribunal que zelava pelo respeito à pessoa humana, constituído por juízes, um conselho jurídico e um secretário. O conselho era representado pelo educador e dois juízes eleitos pelo voto secreto, alterando o cargo a cada três meses e seus membros participavam dos julgamentos e encarregavam-se de criar leis obrigatórias para todos. Havia dois suplentes para cada um dos integrantes do conselho, pois existia a possibilidade de um dos integrantes vir a ser réu em alguma ocasião e, nesse caso, precisaria ser substituído. Conforme Korczak, o secretário não julgava, mas recolhia as disposições das testemunhas, lia-as durante as deliberações do Conselho e era o responsável pelo quadro do tribunal, pelo livro das deposições e veredictos, pela lista e pelos fundos de reembolso para os estragos feitos; o secretário que também traçava a curva das sentenças e redigia o jornal do tribunal. Os julgamentos resolvidos eram lidos em voz alta para todas as crianças. Aqueles que discordassem, podiam apelar da sentença após um mês da data do julgamento. 
Após dois anos de existência do Orfanato, foi criado um Parlamento que contava com vinte deputados, eleitos pelo voto secreto, Korczak como presidente honorário e um secretário. Estes escolhiam entre si uma Comissão Legislativa de cinco membros e um vicepresidente para compor o Senado. Estes aprovavam ou rejeitavam as leis propostas pelo Conselho Jurídico, o estabelecimento do calendário e a atribuição de cartões de lembrança (SINGER, 2010, p.80).

Os cartões de lembrança eram cartões postais dados às crianças como prêmio de bom comportamento em geral. Cada cartão possuía uma imagem e uma mensagem específica, escrita à mão, pelo próprio Korczak, para a valorização de uma boa atitude da criança esperada no orfanato. O parlamento estabeleceu uma lista de valores atribuídos para cada premiação e decidia quais as atitudes mais valorizadas que tinham como recompensa os cartões mais especiais (LIFTON, 2005, p.131). Como exemplo, apresentaremos alguns cartões desse método de estímulo educacional de Korczak

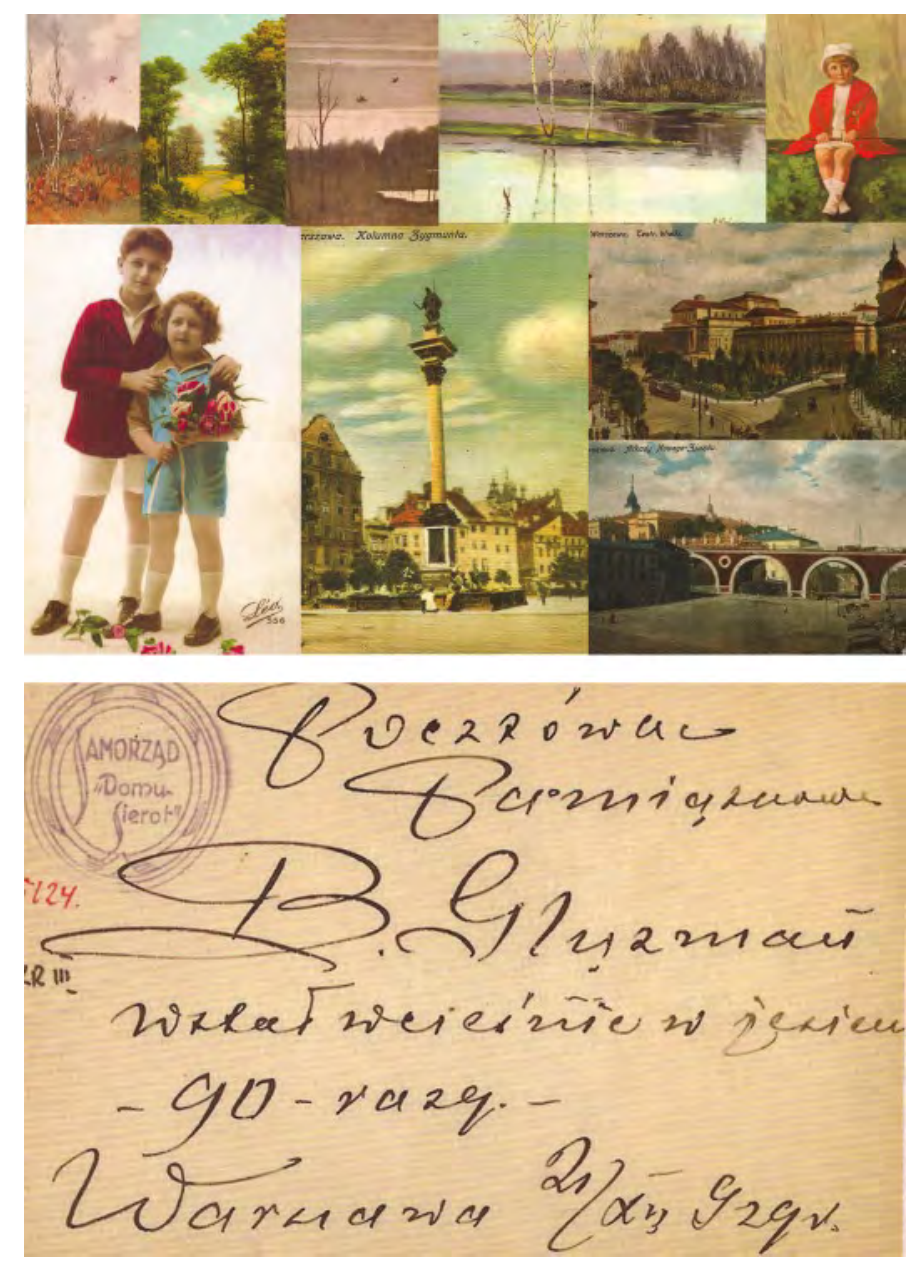

Imagem 11 - Réplica dos cartões postais presenteados por Korczak às crianças.

Fonte: Beit Lohomei Haghetaot. 
Korczak criou um sistema de orientação individual dos internos que se chamou comitê de tutoria, com o intuito de amenizar a adaptação de uma criança recém chegada ao orfanato. O tutor era um morador mais velho que se responsabilizava por uma criança mais nova. Deste modo, o tutor acompanhava a criança nova e ensinava-lhe todas as regras e necessidades do orfanato. O sistema de tutoria era como uma família, pois cada tutor estabelecia uma ligação duradoura com o novo interno, que posteriormente também se tornava tutor de uma nova criança. Assim se estabeleciam relações familiares como numa árvore genealógica, com avós, pais e netos de tutores. A estrutura criava relações duradouras e estáveis entre os internos (LIFTON, 2005, p.123).

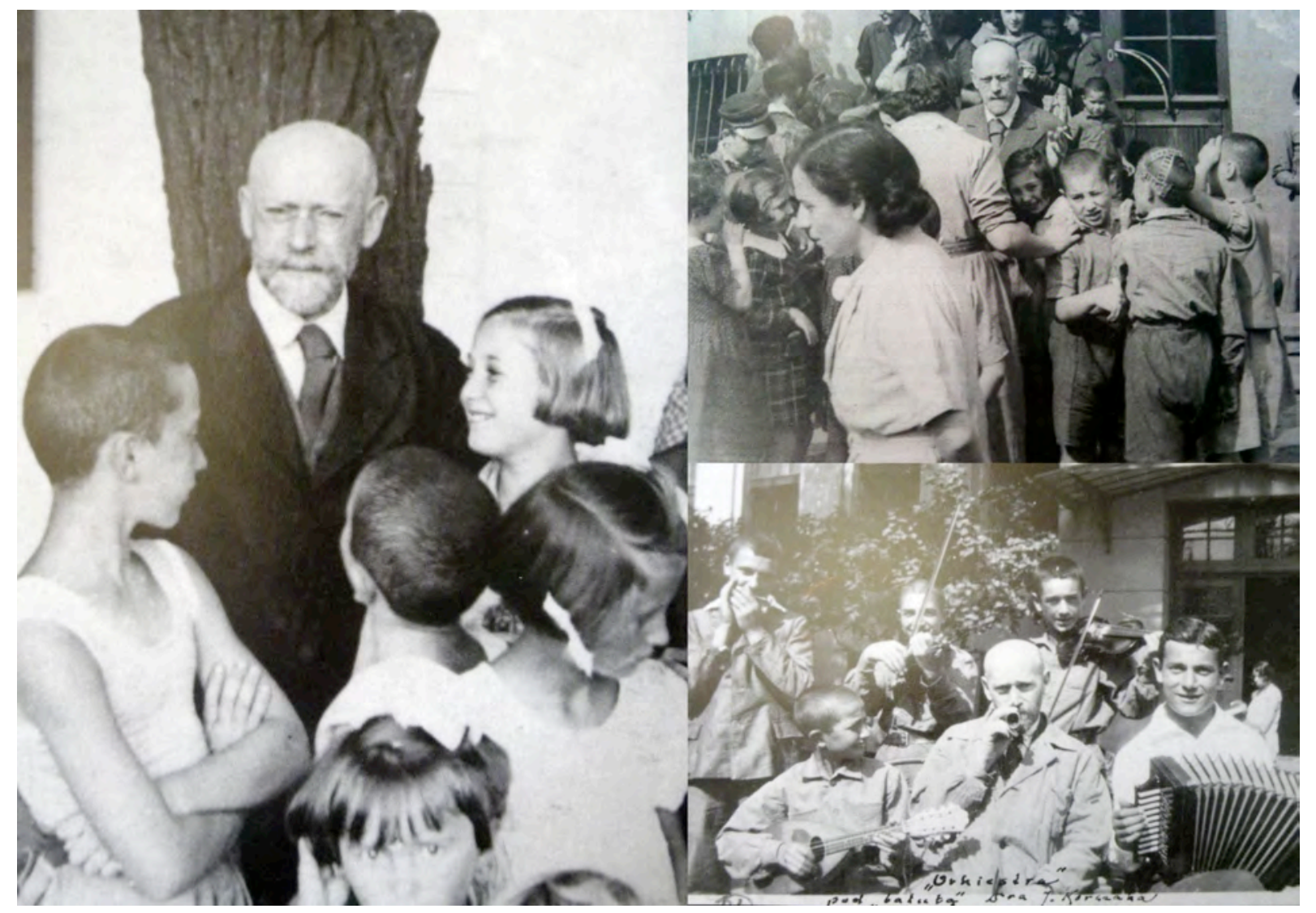

Imagem 12 - Korczak com as crianças no orfanato Don Siderot na década de 30. Fonte: Beit Lohamei Haguetaot.

Circulavam críticas a Korczak na comunidade judaica, acusando-o de favorecer a assimilação dos jovens, fazendo-os perder a identidade judaica e dar uma conotação polonesa ao orfanato. As acusações não procediam, pois Korczak havia instituído no orfanato a 
Kashrut $^{34}$, a observância do shabat ${ }^{35}$ e dos feriados religiosos. Todo o ano realizava o Sêder de Pessach $^{36}$ convidando um rabino e os mantenedores do orfanato para participar com as crianças deste evento (LIFTON, 2005, p. 73).

Por outro lado, quando foram divulgadas as notícias da existência de um orfanato democrático que havia instaurado a autogestão com sucesso, muitos educadores de diversos países vieram conhecer pessoalmente o trabalho de Korczak e Stefa.

\subsection{Na Polônia}

Em 1912, com as crescentes ondas de antissemitismo ${ }^{37}$ em Varsóvia, Korczak decidiu pronunciar-se num artigo no jornal Trzy prady (Lifton, 2005, p.75), com a finalidade de deter o curso crescente de difamações contra a comunidade judaica. Seu artigo dizia que havia três correntes de pensamentos na sociedade polonesa. A primeira, configurada por pessoas da aristocracia polonesa cujos nomes terminavam em ski ou icz e preferiam viver afastadas dos nomes que terminavam com Berg, Sohn e Stein. A segunda, composta por pessoas que eram seguidoras de Salomão, David, Isaias, Macabeus, Halevi, Spinoza pensadores, legisladores e poetas - os mais antigos aristocratas da Europa, com os dez mandamentos como seu brasão, que sempre preferiram viver à parte da sociedade. A terceira corrente cujos membros sempre se declararam filhos da mesma mãe, da mesma pátria, cidadãos que sofreram nas mesmas guerras, se alegraram com as conquistas e eram ligados pela mesma corrente de patriotismo. Korczak dizia que pertencia a última corrente, em que todos os seres humanos eram iguais. (KORCZAK, 1910 apud LIFTON, 2005, p. 377).

\footnotetext{
${ }^{34}$ Kashrut- Leis dietéticas conforme as leis judaicas.

${ }^{35}$ Dia do descanso semanal do judaísmo, simbolizando o sétimo dia da criação, o sábado.

${ }^{36}$ Uma das três festas de Peregrinação ou festas de colheita. É a festa da liberdade, comemorando a redenção dos escravos israelitas do Egito. O Sêder é a refeição ritual familiar comemorada na véspera do primeiro e do segundo dia, dentre os oito dias que compreendem a festa (UNTERMAN, 1994, p. 206).

${ }^{37}$ Termo cunhado no fim do séc. XIX para se referir às posturas e atividades antijudaicas. Em seu significado atual, inclui o preconceito contra os judeus através dos tempos, desde a era pré-cristã até a moderna perseguição política. A natureza do preconceito antissemita tem variado nos diferentes períodos. Em sua forma pré-cristã era em parte nacionalista, já que os judeus não podiam assimilar-se a outras culturas nacionais; em parte escárnio de cunho religioso, já que os judeus adoravam um Deus invisível e, em parte, aversão de caráter econômico aos judeus, que competiam em negócios com seus vizinhos gentios. O cristianismo introduziu acusações de deicídio, uma identificação dos judeus com o demônio, a necessidade de demonstrar a superioridade do Novo Israel (o cristianismo) sobre o Velho Israel, a negação das tendências judaicas no próprio cristianismo e a xenofobia para com o judeu como um elemento estranho à cultura. Mesmo quando começou a haver uma atitude mais positiva para com os judeus, com a política liberal do Iluminismo do séc. XVIII, um renovado nacionalismo europeu alienou novamente e levou ao surgimento de obras antissemitas, como Os Protocolos dos Sábios de Sion. Racistas e fascistas usaram o antissemitismo cristão para fins políticos, culminando na tentativa nazista de resolver a "questão judaica" com o genocídio. (UNTERMAN, 1994, p. 28)
} 
O antissemitismo em Varsóvia foi aumentando gradativamente e os judeus foram acusados de assassinato ritual ${ }^{38}$ acontecido em Kiev, o que repercutiu por toda a Polônia. Korczak, com o intuito de estreitar as relações com os seus vizinhos poloneses, convidou-os para mostrar a rotina das crianças do orfanato em uma tentativa humilde de aliviar o preconceito gerado pelas difamações contra os judeus em geral.

Com a deflagração da Primeira Guerra mundial, em 1914, chegaram a Varsóvia muitos refugiados à procura de abrigo e alimento. Os poloneses, dependendo da região que habitavam, foram recrutados tanto pela Tríplice Entente (liderada pelo Império Britânico e Russo, França e posteriormente os Estados Unidos), quanto pela coligação formada pelas Potências Centrais (liderada pelo Império Alemão, Império Austro-Húngaro e Império TurcoOtomano). Oitocentos mil poloneses lutaram pelo exército russo, quatrocentos mil pelo exército austríaco e duzentos mil pelo exército alemão.

O regime czarista caminhou rumo seu fim com a entrada da Rússia na I Guerra Mundial em 1914 e com a Revolução Russa de 1917. Korczak e Eliasberg foram recrutados e serviram como médicos no front. O orfanato, com cento e cinqüenta crianças, ficou sob os cuidados de Stefa que, com poucos recursos financeiros, conseguiu mantê-lo até o armistício em 1918. Com as doações diminuídas e o empréstimo bancário reduzido, Stefa realizou um trabalho extraordinário para manter o orfanato intacto e as crianças nutridas e protegidas por quatro anos seguidos.

Após a I Guerra Mundial, a Polônia conseguiu reconstituir-se como país independente, com novas fronteiras que incluíam a Galícia, Poznânia e Volínia. "A restauração do país, depois de um século e meio de partilha, não foi conseguida sob a liderança de nenhum dos movimentos políticos devotados exclusivamente a esse fim, mas sob o Partido socialista Polonês, cujo líder, o coronel Pilsudski, se tornou o libertador do país" (HOBSBAWM, 2008, p. 148)

Durante os anos de guerra, Korczak escreveu o livro Como Amar uma Criança ${ }^{39}$ que originalmente era apenas textos com a intenção de acrescentar conhecimentos sobre as crianças para pais e educadores. Era uma síntese sobre a criança, que ele já havia planejado

\footnotetext{
${ }^{38} \mathrm{Na}$ época do $2^{\mathrm{o}}$ Templo, no século 2 da era pré-cristã os selêucidas, por motivos políticos, difamaram o povo judeu afirmando que eles tinham o costume de seqüestrar cidadãos pagãos e sacrificá-los em rituais mágicos. A partir da Idade Média, esses boatos foram repetidos com frequiência, alastrando o terror e aversão aos judeus. A epidemia da peste negra que assolou a Europa em 1348 matando mais de um terço de sua população foi palco de várias insinuações de culpa atribuída aos judeus, contribuindo para o desaparecimento de inúmeras comunidades judaicas da Alemanha. (BORGER, 2002, pp. 58 e 102)

${ }^{39}$ A primeira parte foi publicada em 1919 e a segunda parte, em 1920.
} 
escrever quando esteve por seis meses em Paris. Neste livro, dirigido a pais e professores, conta suas experiências com a medicina pediátrica e a prática educativa. Uma de suas principais afirmações era de que era impossível amar uma criança se esta não tivesse o direito de crescer sendo a pessoa que ela é.

Após a I Guerra Korczak foi solicitado para dar consultoria na criação de instituições para abrigar os milhares de órfãos que perambulavam pelas ruas. Em 1919, ele foi convidado pelo Ministério da Educação polonês para estabelecer um novo orfanato para crianças católicas, filhos de operários, da pequena cidade de Pruzcow, aproximadamente vinte quilômetros ao sul da Polônia. Korczak indicou para o cargo de diretora desse orfanato sua amiga Maryna Falska ${ }^{40}$, que havia conhecido em Kiev onde serviu nos anos da Primeira Guerra. Juntos planejaram e inauguram o orfanato chamado Nasz Dom [Nosso Lar] nos moldes do orfanato judaico Don Sierot.
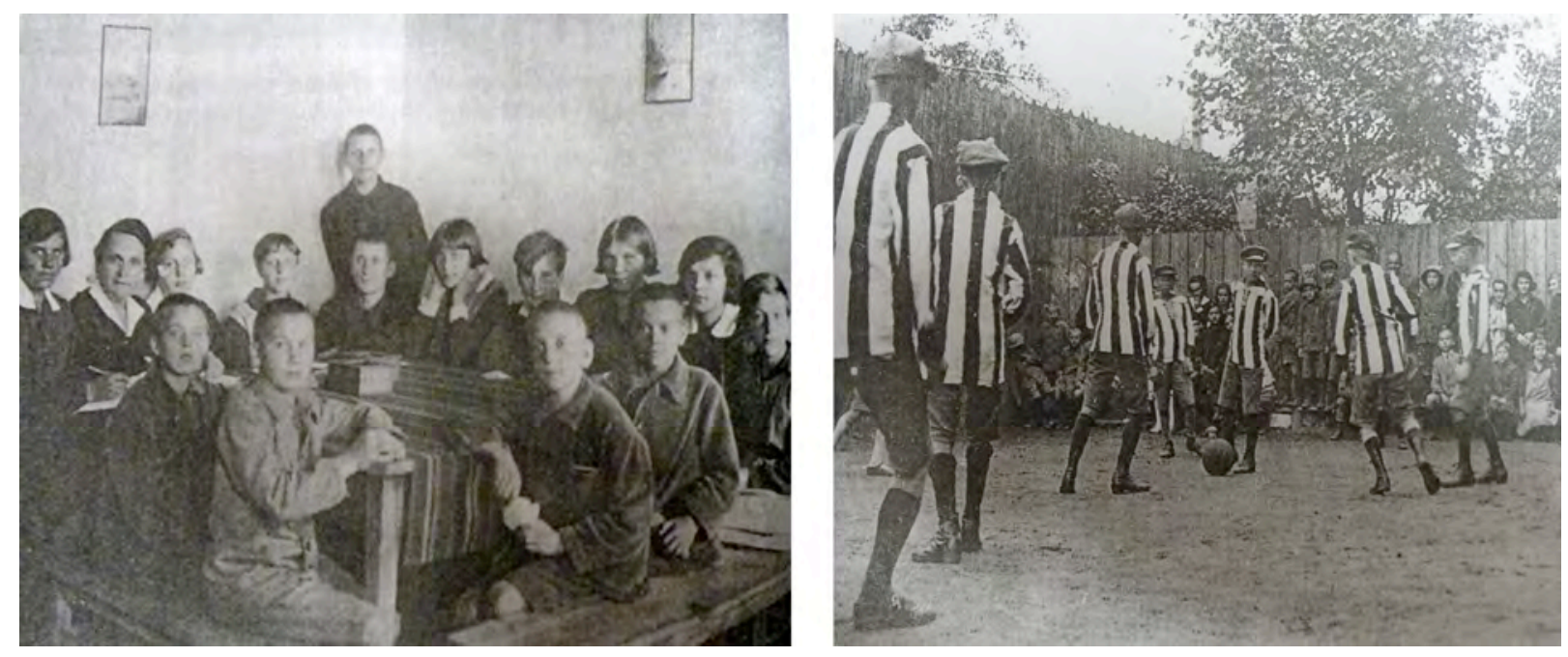

Imagem 13 - À esquerda, Maryna Falska (segunda da esquerda para direita) em sala de aula e à direita jogo de futebol no pátio do orfanato Nasz Dom em 1924.

Fonte: Beit Lohamei Haguetaot.

A Polônia tornou-se independente depois de cento e vinte anos e seu primeiro chefe de estado Joseph Pilsudski convocou o recrutamento nacional para a criação de um exército forte num país espremido entre as forças russas e alemãs. Com o intuito de solidificar a posição da Polônia, Pilsudski aliou-se aos ucranianos e aos lituanos com a finalidade de formar uma comunidade federativa polono-soviética. Os soviéticos aproveitaram-se deste

\footnotetext{
${ }^{40}$ Maryna Falska (1877-1944), polonesa e pedagoga, dirigiu um abrigo em Kiev para sessenta meninos provenientes de Varsóvia, ao longo da Grande Guerra.
} 
período tumultuado e incorporaram mais territórios da Europa Oriental. Em abril Pilsudski iniciou a Guerra polono-Soviética (1919-1921) e enviou suas tropas para recapturar a Lituânia, Minsk e outras cidades contra o domínio soviético. Korczak, com a idade de 41 anos, foi recrutado para servir como major no novo exército polonês no hospital de Lodz.

Com a vitória da Polônia na guerra polono-soviética, houve uma retaliação russa e em 1920 os poloneses foram forçados a evacuar Kiev. O Marechal Pilsudski recuperou as forças de seu exército e expulsou os soviéticos do país. Este feito foi chamado de o Milagre do Vístula e foi registrado com orgulho por Korczak no livro no Diário do Gueto:

Varsóvia pertence a mim e eu lhe pertenço. Digo mais: eu sou a cidade. Dividi com ela suas alegrias e suas tristezas; o seu bom tempo era o meu, a sua chuva e a sua lama eram também as minhas. Cresci com ela. Ultimamente estamos um pouco afastados um do outro. Novas ruas, novos bairros nasceram que eu não acompanhava mais. Durante anos senti-me como um estranho no Zoliborz ${ }^{41}$, ao ponto que Lublin e Hruebiezow ${ }^{42}$, onde jamais pus os pés, me eram infinitamente mais próximas. Varsóvia era sempre o lugar escolhido do meu trabalho; aqui instalei meu consultório, para cá que sempre voltei, aqui é que tenho todos meus túmulos.

Nessa guerra, Korczk contraiu tifo e regressou a Varsóvia para recuperar-se da doença na casa da mãe. Ela também foi infectada e morreu antes da recuperação do filho. Esta perda levou - o a escrever o livro A Sós com Deus onde ele conta sua tristeza pela falta da mãe. Diferente de tudo o que já havia escrito, este é um livro que analisa psicologicamente sua relação com Deus. Assim como Buber (1878-1965) que explicou a relação dialógica com Deus como um encontro interpessoal, Korczak acreditava que o encontro com a fé acontecia de forma semelhante, independentemente da necessidade do rabino, da sinagoga ou de qualquer ritual religioso. Os textos do livro A sós com Deus provocam, sob os mais diferentes enfoques, a reflexão sobre as relações humanas com o divino.

Em 1921, o primeiro censo da nova Polônia registrou o número de 2.800 .000 judeus distribuídos por todo o seu território, 10,4\% do total da população polonesa (BORGER, 2002, vol.II, p. 483). Ainda que o Tratado de Versalhes defendesse os direitos das minorias e a Constituição polonesa proibisse a discriminação, o antissemitismo estava enraizado em toda a Polônia.

\footnotetext{
${ }^{41}$ Zoliborz: um dos bairros de Varsóvia.

${ }^{42}$ Lublin e Hrubieszow são cidades da Polônia meridional. Hrubieszow é a cidade de origem da família de Korczak.
} 
A partir de 1933, ecos da política antissemita alemã ressoavam em toda Europa Oriental. Os pogroms intensificaram-se, o governo negava subsídios às escolas judaicas e dificultava o ingresso dos judeus nas universidades. Os judeus eram excluídos dos serviços públicos, cargos em banco, comércio e empregos nas indústrias. "Uma pesquisa feita em Bialystkok mostrou que, entre 1932 e 1937, setenta lojas de judeus fecharam as portas enquanto as de cristãos aumentaram em 591." (BORGER v. 2, 2002, p.484). Entre 1933 e 1939, a política oficial do nazismo era excluir radicalmente os judeus da vida econômica, social e cultural alemã e forçar a expulsão do país. Para isso, cerca de 400 leis e decretos antijudaicos foram impostos. Além do serviço público, os judeus foram excluídos das profissões liberais, das artes, do cinema, rádio, teatro, das escolas, universidades, dos esportes, das organizações culturais e profissionais e cargos de direção de empresas. (CYTRYNOWICZ, 1990, p.19). Na Alemanha e na Áustria uma onda de violência antissemita atingiu o ápice nos dias 9 e 10 de novembro de 1938, na chamada "Noite dos Cristais". Esse nome foi atribuído ao dia em que os vidros de armazéns, residências e lojas de judeus foram quebrados e as sinagogas foram incendiadas e devastadas. Judeus foram espancados até a morte e vinte e seis mil foram internados em campos de concentração.

Por outro lado, em Varsóvia e em Lodz, constitui-se, entre as duas grandes guerras, uma elite intelectual e socialmente proeminente que falava polonês. Korczak era um dos representantes dessa elite que conheceu, por um breve e próspero período, o desenvolvimento do teatro, do cinema e da literatura iídiche e hebraica. De acordo com Lifton (2005, p.229) Korczak alcançou o reconhecimento de suas obras como escritor em 1937, quando recebeu o Golden Laurel da Academia Polonesa de Literatura.

\subsection{Encontro com a Terra de Israel}

Em 1934 e 1936, Korczak viajou para a Palestina e ficou hospedado no kibutz Ein Harod. O desejo de Korczak de conhecer a Terra de Israel aconteceu por influência de duas educadoras de seu orfanato que imigraram na década de vinte para a Palestina e vários educadores que seguiram o mesmo destino. As educadoras Feiga Lipshitz e Ester Budko Gad iniciaram uma troca de correspondência que continha toda a dificuldade e desafios de adaptação a uma nova terra. As cartas pesquisadas são as respostas de Korczak às questões dos jovens e são um testemunho das ideias, questionamentos e situações vividas por Korczak na Polônia. 
Os educadores do orfanato eram em sua maioria monitores de movimentos juvenis sionistas que aproximaram Korczak e Stefa de uma nova realidade. Os educadores, com aprovação de Korczak, promoveram o encontro das crianças do orfanato com as crianças dos movimentos juvenis, introduziram o ensino da língua hebraica e transmitiram ideias sionistas para a construção de uma sociedade justa na Terra de Israel.

A estada de Stefa por três meses no kibutz Ein Harod em 1932 foi o impulso que Korczak precisava para decidir conhecer a terra dos ancestrais. Nas duas estadas na Terra de Israel, Korczak foi convidado diariamente a proferir palestras sobre educação, o modelo democrático de autogestão dos dois orfanatos que desenvolveu e sobre temas pediátricos. Os desafios dos jovens pioneiros na realização de seu ideal sionista, o sistema de educação desenvolvido no kibutz, a vida das crianças e o trabalho agrícola foram temas que suscitaram em Korczak muitos questionamentos pessoais. E diante desses fatos ele expressou em suas cartas o permanente desejo de retornar à Terra de Israel para visitar mais uma vez ou morar definitivamente.

Sua aproximação à causa sionista e suas duas viagens serão apresentadas com mais detalhamento no capítulo 2 do presente estudo.

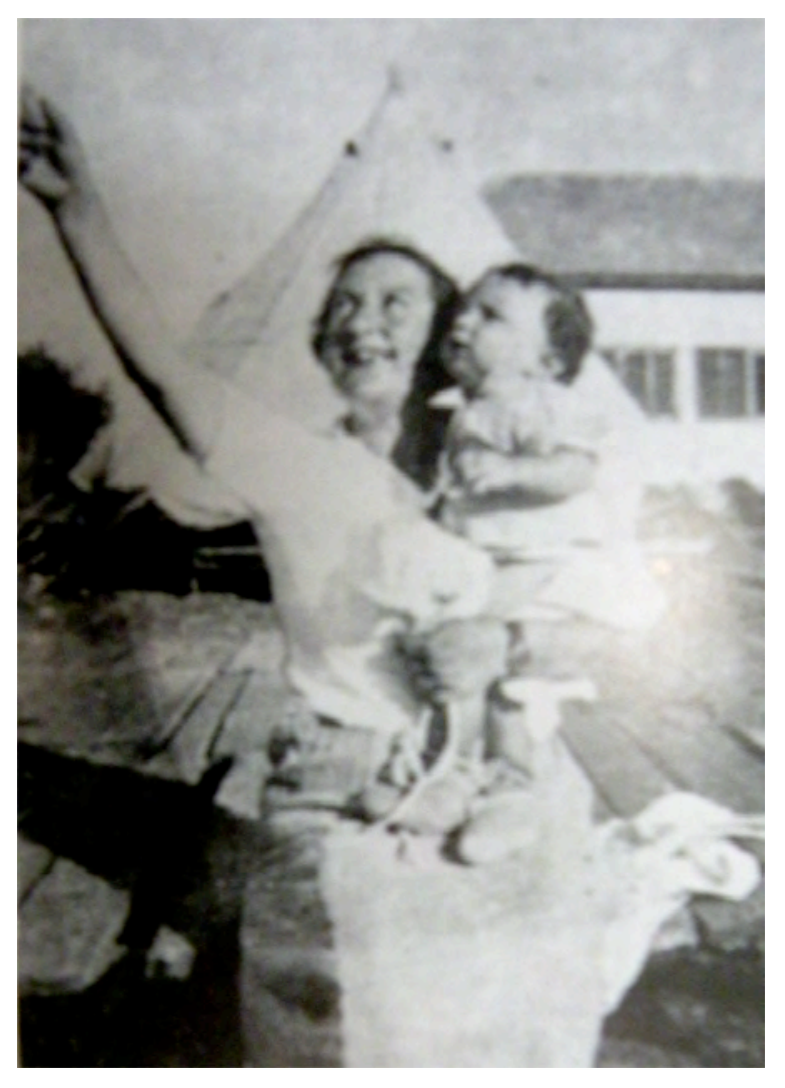

Imagem 14 - Stefa com bebê, no Kibutz Ein Harod, Israel, 1931.

Fonte: Beit Lohamei Haguetaot. 


\subsection{Vítima do Nazismo}

Nos anos que precederam a Segunda Guerra Mundial, a ascensão do nazismo e a crescente onda de antissemitismo dificultaram a carreira profissional de Korczak. O homem intelectual, ativo da elite cultural polonesa, respeitado e integrado na sociedade, foi afastado da direção do orfanato polonês, do seu programa de rádio, impedido de publicar seus artigos nos jornais poloneses e foi desligado do cargo de conselheiro da Corte juvenil de Varsóvia.

O exército de Hitler invadiu a Polônia em $1^{\text {o }}$ de setembro de 1939. "A maior comunidade judaica da Europa caiu nas garras nazistas" (BORGER, 2002, p. 627). Em 21 de agosto, foi ordenada a retirada dos judeus das pequenas cidades e da zona rural polonesa. Três milhões e trezentos mil de judeus poloneses foram submetidos ao controle alemão. Os judeus com idade superior a doze anos foram obrigados a usar uma braçadeira branca ostentando uma estrela de David azul. Eles foram rapidamente concentrados em guetos, primeiramente nos territórios incorporados ao Reich. Na primavera de 1940, o movimento de confinamento nos guetos ganhou o governo geral da Polônia, com a criação do gueto de Varsóvia, em seguida, em março de 1941, do de Cracóvia e em abril de 1941, do de Lublin (WIEVIORKA, 2010, p. 593).

Korczak recusou-se a aceitar a nova realidade. Desdenhou a ordem germânica para que cada judeu usasse a braçadeira com a estrela de David, vestiu o seu uniforme do exército polonês sem a insígnia (ARNON, 2005, p 67). Esta era a sua quarta guerra e foi, juntamente com as crianças e os educadores do orfanato, confinado no gueto de Varsóvia. Da ampla e moderna casa da Rua Krochmalna mudaram-se para um endereço que mal abrigava o número crescente de órfãos. 
Imagem 15 - Ficha cadastral nazista preenchida por Korczak no gueto de Varsóvia em 1939.

Fonte: EDEN, 2000, p. 249.

Imagem 16 - Korczak com seus amigos Haim Burshtein e Ari Kalisher (de óculos, foi aluno de Korczak no Orfanato e redator do jornal infantil Mali Psheglond), em Varsóvia no ano de 1939. Fonte: Dat Hayeled, 1978, p. 48.
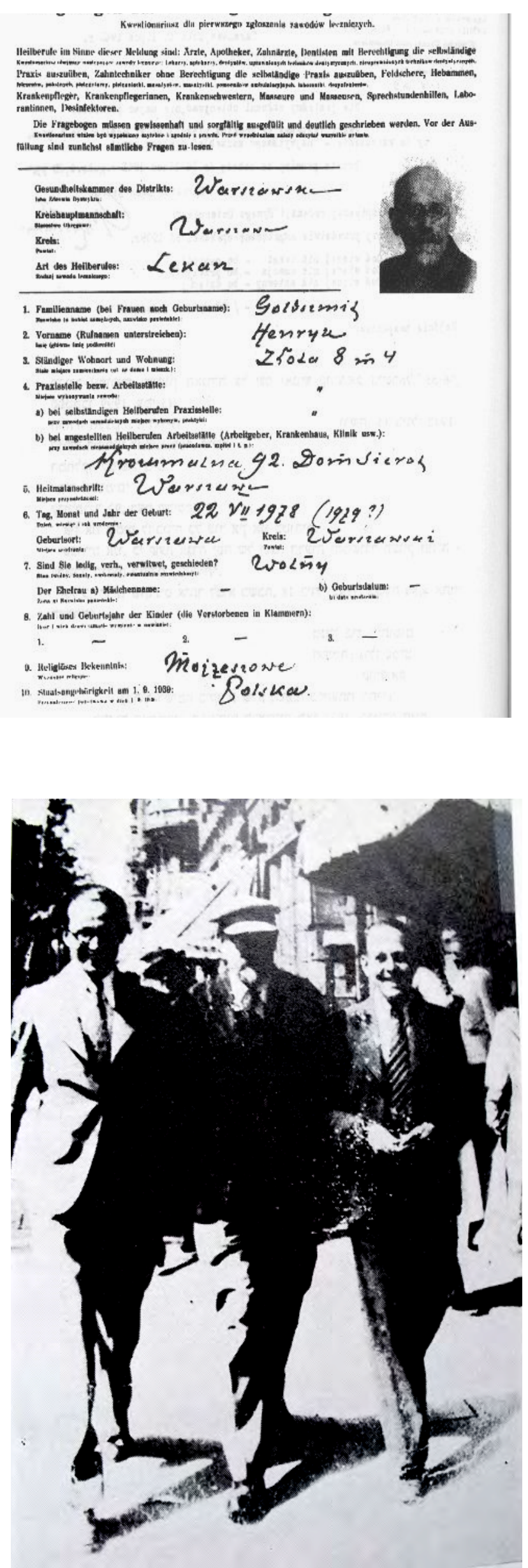
Mas a vida das crianças continuou com os mesmos bons costumes e leis do orfanato independentemente da tragédia que ocorria rotineiramente dentro do gueto:

As crianças ouviam as histórias de seus professores, brincavam com seus jogos habituais, e continuavam a reunir sua "corte" - tudo com a seriedade e a concentração apropriadas. Korczak estava ali ao lado delas, e as crianças sentiam sua presença sem que ele pesasse sobre elas, ou elas sobre ele. Ele cuidava para que as crianças ao menos continuassem a estudar leitura, escrita e aritmética, e até inventou um novo sistema de "cartões de estudo individual". Ocasionalmente ele convidava conhecidos estudiosos judeus, que estavam agora confinados ao gueto, para lecionar matérias de natureza histórica, social ou literária. ( ARNON, 2005, p.69)

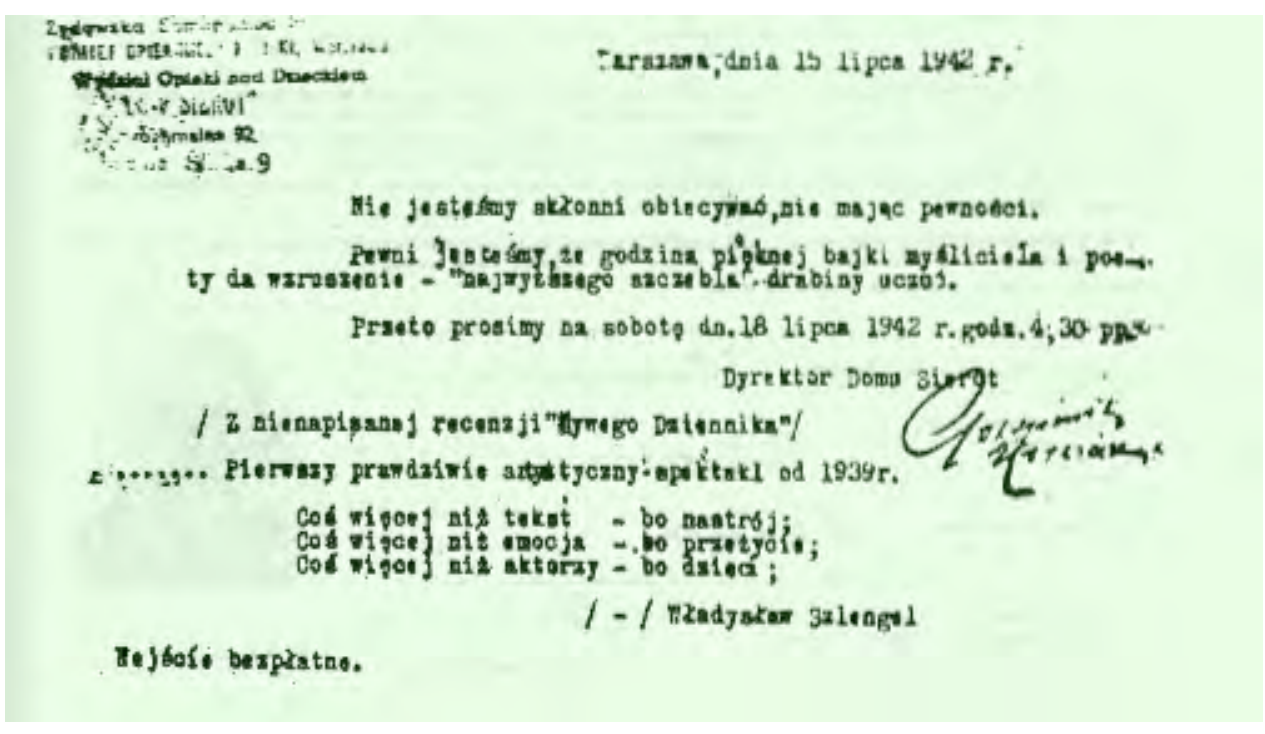

Imagem 17 - Convite para a peça de teatro $O$ Correio representada pelos alunos de Korczak no gueto de Varsóvia em 18/07/1942. Fonte: EDEN, 2000, p. 250.

Entre 22 de julho e meados de setembro de 1942, mais de 300.000 pessoas foram deportadas do gueto de Varsóvia para os campos de extermínio. As crianças do orfanato, entre outras vítimas, foram enviadas para a morte no campo de extermínio de Treblinka. Em agosto de 1942, em meio a todo este terror e podendo salvar-se - em virtude de seu renome internacional - Korczak uniu-se a Stefa e aos outros educadores e caminharam juntos com as crianças para seu destino final, cantando em marcha organizada em direção ao trem que os aguardava:

"À frente da procissão macabra, ele caminhou pelas ruas de Varsóvia levando nos braços duas crianças fracas, que já não podiam andar sozinhas." (ABRAHAM, 1998, p. 87) 
Os mil anos de presença judaica na Polônia terminaram com assassinato em massa e sofrimento numa escala quase além da imaginação humana. Dos 3300000 judeus que viviam nesse país em 1939, não restarem mais do que algumas dezenas de milhares em 1945 (idem, p.595).

A tragédia da Shoá mudou de forma definitiva a história de Janusz Korczak, de Stefania Wilczynska e das duzentas crianças do orfanato Don Sierot, da Polônia, dos judeus e de todo o mundo.

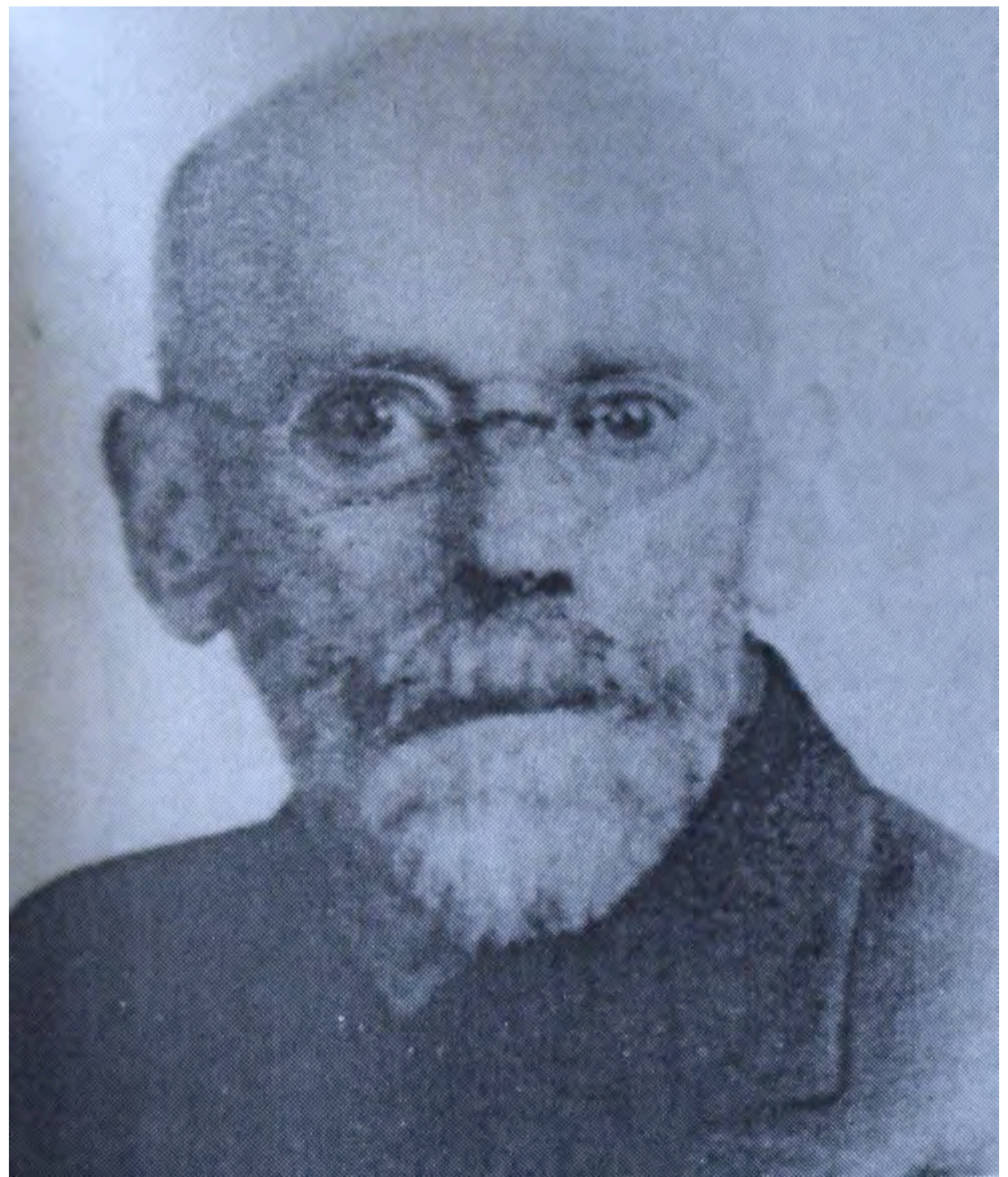

Imagem 18 - A última foto de Korczak no Gueto de Varsóvia em 1941. Fonte: LIFTON, 2005, p. 201. 


\section{Rumo ao Sionismo}

\subsection{Judeu - Polonês}

Janusz Korczak descobriu a identidade judaica aos cinco anos de idade acidentalmente e desde então, ao longo da vida, esta questão foi para ele motivo de curiosidade e dúvida. A identidade polonesa era muito forte, pois havia lutado pela Polônia em três guerras: a guerra russo-Japonesa (1904-1905), a Primeira Grande Guerra (1914-1918), integrando o exército russo, e a guerra Bolchevika-Polonesa (1917), como major do exército. Além disso, ao ingressar na vida acadêmica estabeleceu amizades com a intelectualidade judaica de Varsóvia. A trajetória de aproximação ao judaísmo ocorreu lentamente e por seu interesse, pois não havia recebido na casa dos pais os conhecimentos fundamentais da tradição judaica.

Diferente da maioria dos lares judaicos, mesmo seculares, que enviavam os filhos às escolas judaicas primárias, Korczak estudou em escolas polonesas. A família não tinha o hábito de se comunicar em iídishe ou hebraico, fato comum entre judeus da Europa Oriental. A maioria dos intelectuais judeus, assim como Joseph, o pai de Korczak, possuíam formação religiosa na infância, secular na adolescência e acadêmica na idade adulta (LIFTON, 2005, p.21).

Por outro lado, Korczak, além de ter atuado em diversas áreas ligadas à educação, com especial dedicação à criança, envolveu-se com o sionismo e com a questão da dupla identidade: judaica e polonesa. Nesse aspecto, fez duas visitas à Palestina nos anos 30, que influenciaram significativamente suas ideias sobre a Terra de Israel $^{43}$ e o sionismo.

De acordo com Perlis (1986, p. 224), Korczak aproximou-se do judaísmo no decorrer da vida: "O primeiro momento deu-se por solidariedade humana, em seguida identificação e ao final um retorno completo". Embora Korczak tenha recebido educação secular ele fez, ao longo da vida, a escolha pessoal de pertencer ao povo judeu e ao judaísmo.

\footnotetext{
${ }^{43}$ Korczak se referia à Palestina com o termo hebraico bíblico: Eretz Israel (Terra de Israel)
} 
Nesse sentido, o primeiro contato de Korczak com algumas famílias judias aconteceu após a doença e falecimento do pai. A família Goldszmit sofreu com a perda do patriarca em 1896, com a idade de 52 anos. Korczak, por sua vez, assumiu a responsabilidade pelo sustento da família com a idade de 18 anos. Sua mãe, na condição de viúva, obteve uma licença do conselho de educação para que seu filho trabalhasse como tutor de crianças dentro de seus lares. Com a finalidade de obter alunos para o filho, a Sra. Goldszmit publicou a notícia na edição quinzenal do jornal Israelite ${ }^{44}$.

Sua aproximação com ativistas sionistas ocorreu em 1899, quando, aos 21 anos de idade, de férias por três semanas na Suíça, teve sua primeira experiência fora dos limites da Polônia. Ao final de seu primeiro ano letivo da faculdade de Medicina, presenciou o Terceiro Congresso Sionista na Basiléia ${ }^{45}$. Em seus registros no semanário polonês "Czytelnia dla Wszystkich", A leitura para todos, (SHARSHEVSKI, 1990 apud SCHNER, 2005, p.40), escreveu sobre a natureza do lugar, o nível cultural e social dos cidadãos suíços, a educação, sobre o destino das pessoas naquelas terras e sobre a situação difícil das crianças em Varsóvia. Entretanto, não mencionou especificamente o Congresso. Somente após 26 anos, em 1925, Korczak mencionou o Congresso Sionista em uma carta (SHARSHEVSKI, 1990, p.106, apud SCHNER, 2005, p.40), descrevendo-o como sua primeira conexão com a Terra de Israel.

Nesse sentido, é necessário entender o contexto do desenvolvimento da ideia sionista.

\subsection{Movimento Sionista}

\subsubsection{Desenvolvimento}

Durante dezoito séculos de exílio, a ligação da comunidade judaica com a Terra de Israel se manteve presente no seu sistema de valores e na autoconsciência grupal. E sempre houve uma comunidade judaica na Palestina, ainda que pequena, com a intenção de continuar a viver nesta terra. Esse vínculo nunca se desfez, revigorando-se à medida em que a Palestina era vista simultaneamente como terra do passado e da reconstrução do futuro.

\footnotetext{
${ }^{44}$ Essa nota foi encontrada no jornal Israelite, 23 de setembro de 1986. (LIFTON,1988, p. 370)

45 Também conhecido como "O Parlamento do povo Judeu", é uma associação sionista fundada na Europa em 1897 por Theodor Herzl para discutir a concretização do retorno dos judeus à Terra de Israel-Palestina. As reuniões acontecem até o presente e está vinculada à Organização Sionista Mundial e Agência Judaica e participa do governo de Israel.
} 
Nesse aspecto, o judaísmo não era definido apenas como uma religião, pois continha elementos étnicos e nacionais que nunca perdeu. Foi essa ligação com a pátria distante dos antepassados que marcou a diferença do judaísmo em relação às comunidades cristã e muçulmana.

Os judeus pertenciam a uma nação não nacional e a nacionalidade, a partir da Revolução Francesa, tornou-se a base suprema da autoconstituição do grupo, igualando os cidadãos. Dentro deste contexto, o judeu era um paradoxo, pois ora era considerado aliado ora inimigo (BAUMAN, 1996, p.73-74).

Nesse aspecto, o caso Dreyfus ${ }^{46}$ foi a mais radical constatação da precariedade da condição judaica na Europa dos nacionalismos em sua manifestação declaradamente antissemita. Foi conferida aos judeus franceses a cidadania e todos os direitos que lhe eram inerentes através da Constituinte que punha fim ao secular regime discriminatório. Porém, no caso Dreyfus, a frágil vitória do direito à equidade nacional atingiu o auge.

A crença sobre o retorno à Terra de Israel nunca desapareceu, mas a história nos mostra que os judeus nunca se engajaram de forma ativa para imigrarem, como uma nação, para a Terra de Israel. Até mesmo no pensamento religioso foram criadas formas para autenticar esse amor passivo à Terra de Israel, como a afirmação de que Deus se ocuparia de dar sinais do dia certo ao retorno a $\operatorname{Sion}^{47}$.

O forte sentimento de união com a Terra de Israel talvez seja o maior símbolo da identidade judaica, ao mesmo tempo em que, até a metade do séc. XIX, não apareceu nenhum movimento ativo para o retorno judaico à Palestina. Nesse período, ocorreu a transformação de um laço originalmente religioso numa potente força de ação dentro da atmosfera secularizada, ou seja, distante da religião: o sionismo.

Avineri (1988, p.14) nos ensina que os estudos mais comuns ligam o sionismo a vários fatores decisivos que aconteceram na Europa, como o antissemitismo, a aparição das teorias racistas na Alemanha e na França, o caso Dreyfus, os pogroms da Rússia em 1881 e 1882 e as matanças de Kishinev, em 1903.

\footnotetext{
${ }^{46}$ Alfred Dreyfus, o único judeu no estado-maior do exército francês, foi acusado de traição no final de 1894 com base em provas mais tarde conhecidas como forjadas. A questão da culpa ou inocência de Dreyfus polarizou a opinião pública da França entre 1897 e 1899. (SELTZER, vol.II, 1989, p.626). Émile Zola, jornalista defendeu Dreyfus ao publicar o artigo "J'acuse", no qual acusava o exército por calúnia contra o cidadão honesto. Em 1899 foi anulada a sentença contra Dreyfus, porém ficou claro o ódio aos judeus e a desconfiança geral para com a república, o Parlamento e a máquina do Estado .(ARENDT, 1973, p.115).

${ }^{47}$ Nomenclatura que se refere à Terra de Israel.
} 
Os judeus foram perseguidos pelos visigodos e bizantinos, massacrados durante as Cruzadas, expulsos da Inglaterra, da França, da Espanha e de Portugal, não podiam residir em cidades imperiais do sacro Império Romano, foram convertidos à força na Pérsia e em Portugal, obrigados a vestir artigos distintivos e impedidos de ocupar cargos públicos na Itália Cristã e no Marrocos muçulmano. Em todos esses casos, a reação judaica foi de resignação e a emigração se dirigia para outros países, mas não à Palestina.

No século XIX, somente $1 \%$ da população judaica do leste europeu imigrou para Palestina por causa dos pogroms russos. A grande maioria foi para os Estados Unidos, Canadá, América do Sul e a Austrália. O século XIX foi o melhor momento para os judeus, tanto coletiva como individualmente desde a destruição do Templo. Com a Revolução Francesa e a emancipação, foi a primeira vez que os judeus foram aceitos na sociedade europeia como cidadãos, e, pela primeira vez, gozaram da igualdade perante a lei e puderam ingressar nas escolas, universidades e profissões que tradicionalmente lhes eram vetadas. Os anos entre 1815 e 1914 foram anos revolucionários para a história judaica (AVINERI, 1988, p.15), tanto economicamente como nos aspectos sociais, políticos e intelectuais.

Até 1815, a população judaica da Europa vivia em comunidades à margem da sociedade gentia. Os judeus viviam em aldeias rurais desde o século XVIII, pois a czarina Catarina II obrigou-os a viver em regiões demarcadas, como nos shtetls ${ }^{48}$ do Distrito de Demarcação da Europa Oriental e nos distritos rurais como Hesse e Alsácia. Nas grandes cidades da Europa, como Paris, Viena, Londres, Moscou e São Petersburgo, os judeus eram marginalizados. Com o aval da teologia cristã, eles eram excluídos da maioria das profissões. Além disso, não podiam ingressar nas escolas e universidades, não podiam ser funcionários públicos ou servir o exército. Os judeus se conformavam na melhor das hipóteses com a tolerância de suas crenças, tornando-se pequenos intermediários mercantis para suprir seu sustento. Até 1815, há raras referências da existência de judeus que se destacaram nas áreas de política, filosofia, finanças, medicina ou nas artes.

Após esses 100 anos, desde a emancipação judaica obtida pelo movimento da Haskalá [ilustração judaica], houve uma onda migratória das periferias aos centros urbanos da sociedade europeia. Os judeus foram para Berlim, Viena, Budapeste, Varsóvia, Londres, Paris, Odessa, Nova York, Chicago, e Filadélfia. Começaram a se destacar nas áreas intelectuais, ingressando nas escolas, academias e universidades. Alcançaram posições importantes nos jornais, na literatura, na música, na ciência, na pintura, na filosofia e na

\footnotetext{
${ }^{48}$ Pequena aldeia ou cidadezinha de densa população judaica.
} 
psicologia. Nos movimentos revolucionários, havia vários líderes judeus se enfronhando no movimento revolucionário russo, tais como, Marx, Moses Hess e Ferdinand Lassalle. Originários de uma comunidade marginal transformaram-se em grandes atuantes do Iluminismo, da Emancipação, da Revolução Industrial. E toda essa conquista aconteceu em menos de cem anos.

Antes do Iluminismo e da Revolução Francesa, o judeu era identificado somente por suas crenças religiosas. A Haskalá e a secularização, em decorrência da Revolução Francesa, fizeram com que os judeus alterassem a percepção que tinham sobre si mesmos e também sobre a percepção que a sociedade não judia tinha sobre eles. Aqueles judeus que optaram por não se assimilar permaneceram fiéis a sua crença religiosa e a seu modo de viver.

Nesse equilíbrio hierárquico e não igualitário, o judaísmo foi capaz de existir por dois milênios. Os princípios básicos deste equilíbrio e a separação dos judeus como comunidade religiosa diferente foram internalizados tanto por judeus como por não judeus. As perseguições, conversões forçadas, pogroms, incêndios e expulsões alteraram frequentemente este equilíbrio.

Foi esse equilíbrio que fez com que o judeu sobrevivesse em meio a um ambiente hostil. E o fez internalizar seu estatuto legal inferior, legitimado por uma sociedade gentia com o sentimento de que o cristianismo era a religião triunfante e a comunidade judia existia pela teologia do exílio.

O caráter universalista da revolução francesa foi um divisor de águas pelo valor histórico do nacionalismo moderno. O dilema de identidade não podia ser resolvido pela conversão religiosa. Muito do nacionalismo moderno baseia-se nas origens e está enraizado pelo determinismo cultural e pelo racismo. O problema cultural com o qual se confronta o judeu moderno torna se insuportável, especialmente na Europa Oriental, onde vivia a maioria dos judeus, principalmente porque nesta zona havia muitos movimentos nacionais que competiam entre si e os judeus encontravam-se em meio ao fogo cruzado. (AVINERI, 1988, p. 22).

Assim, o liberalismo e o nacionalismo favoreceram o judeu para que começasse a desenvolver uma nova autoconsciência, não determinada pela religião, mas semelhante ao nacionalismo moderno e secular da Europa. O desenvolvimento de uma nova literatura hebraica, a da Haskalá judaica, foi o primeiro passo nessa direção. Foi seguida pelo sionismo político de Leo Pinsker, Teodor Herzl e Max Nordau. E o mais significativo é que na 
biografia de todos estes fundadores do sionismo moderno aparece, uma ou outra vez, o mesmo fenômeno: nenhum era de origem religiosa ou tradicional. Todos eram produto da educação europeia, e imbuídos das ideias em voga na inteligência da Europa.

O sionismo é, portanto, um fenômeno pós-emancipatório. Fenômeno que foi delineado sobre um laço histórico com a ancestral Terra de Israel, convertendo-se, de um símbolo que havia permanecido adormecido e passivo, potente na tradição religiosa judaica ${ }^{49}$, em um objetivo histórico-prático ativo. O nacionalismo judaico foi, então, uma consequência das novas ideias e do desenvolvimento social desencadeados pela Revolução Francesa, pelo modernismo e pelo secularismo. Foi uma resposta aos desafios do liberalismo e do nacionalismo e não uma mera reação ao antissemitismo. Por essa razão, não poderia ter ocorrido antes dos séculos XIX e XX.

O sionismo constituiu uma revolução fundamental na vida judaica. Substituiu a autoidentidade tradicional, ortodoxa, baseada na religião por uma identidade secular dos judeus como nação. Transformou a esperança passiva do retorno a Sion em uma força social efetiva que moveu milhares de pessoas à Palestina. Transformou um idioma ${ }^{50}$, relegado ao uso ritual, à forma de comunicação secular de um estado-nação, levando ao renascimento do idioma hebraico.

Todas as tentativas para explicar os laços dos judeus com a Palestina não são suficientes para explicar por que e quando surgiu o sionismo. O sionismo, ao contrário de ser somente a reação de um povo sob perseguição, foi também um movimento em busca da auto determinação e da liberação sob modernas condições de secularização e modernismo. Portanto, faz parte da história judaica de dispersão e retorno, como também da história universal da liberação e da busca da identidade. (AVINERI, 1988, p.24.)

\footnotetext{
${ }^{49}$ A religião determinava também o estatuto legal: sendo judeu, não se podia naturalmente fazer parte da política A sociedade cristã considerava sua organização política como expressão dos dogmas do cristianismo. Nesta sociedade, o judeu podia ser tolerado dando-se a liberdade de culto, mas com uma separação clara, definida e legitimada de discriminação. Em um estado cristão, uma pessoa que não acreditava em Cristo não podia ocupar um cargo público, nem exercer autoridade sobre cristãos. Não podia participar do vínculo com o feudalismo, portanto, não possuía terra. Nos países muçulmanos, com raras exceções, como na Espanha muçulmana, a situação era mais ou menos parecida. (AVINERI,, 1988, p. 17).

${ }^{50} \mathrm{O}$ movimento político sionista foi precedido, na Europa Oriental, pelo renascimento do idioma hebraico como meio de comunicação literário e não religioso. Este era o renascimento da língua hebraica como um idioma para novelas e poemas, artigos polêmicos e folhetins periódicos. Os judeus emancipados e secularizados começaram a investigar as origens de sua cultura, as raízes de sua historia, a exaltar as glórias de Jerusalém, a perguntar-se sobre seu passado, assim como os membros de outros grupos estavam fazendo. "A literatura da Haskalah colocou os alicerces do sionismo, por meio dos temas bíblicos que despertaram o anseio por uma existência livre e pela plenitude nacional. E preparou o terreno para o renascimento do hebraico como linguagem diária, elaborando ao máximo os meios de expressão do hebraico bíblico, adaptando-os para transformá-los em veículos de pensamento da era moderna”. (RABIN, 1973, p.87)
} 
Dentre os diversos defensores da causa sionista um dos maiores representantes foi Theodor Herzl que, em suas palavras, afirmou que:

"Nós somos um povo. Temos tentado sinceramente fundir-nos com as comunidades nacionais em cujo meio vivemos, preservando apenas nossa fé ancestral. Mas não nos deixam. Portanto, resta uma só alternativa: o êxodo para uma terra própria. Princípios políticos formarão a base, a tecnologia os meios e a aflição judia será a força propulsora. O Estado deve ser formado numa escala generosa, no espírito do progresso social. A jornada de trabalho de sete horas será nossa bandeira. A iniciativa privada será estimulada, mas visara ao interesse público. As mulheres terão absoluta igualdade de direitos" ${ }^{51}$.

O Der Judenstaat, O Estado Judeu, detonou uma reação em cadeia de pensamentos, instituições, homens, e ação. Transformou seu autor em um líder de grande carisma e produziu resultados históricos. (BORGER, 2002, p. 445)

\section{JUDENSTAAT.}

VERSUCH

EINER

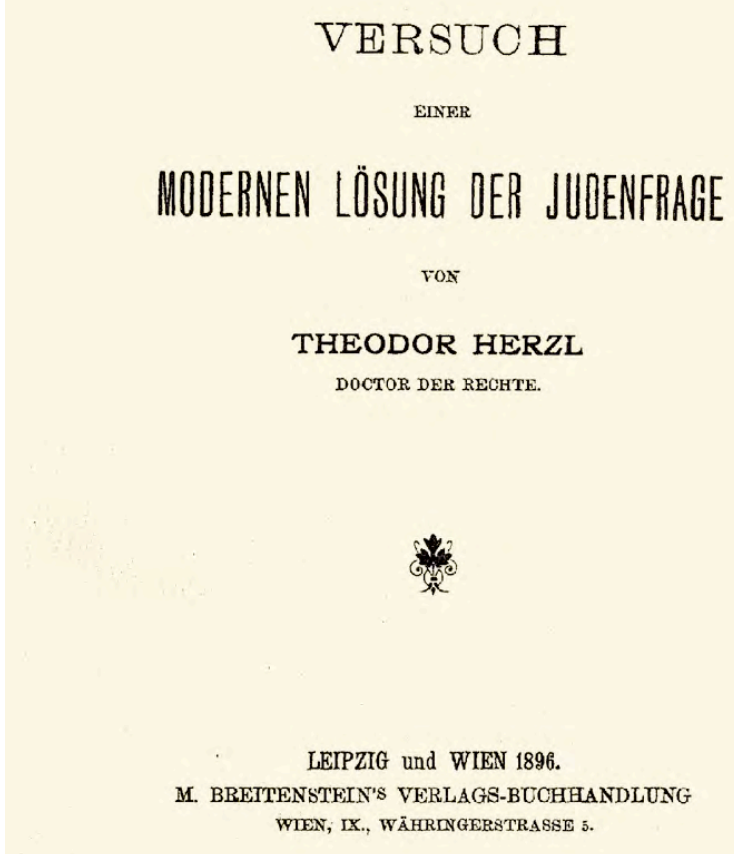

ros

THEODOR HERZL

DOCTOR DER RECHTE.
Imagem 19 - Primeira edição de Der Judenstaat de Theodor Herzl, 1896. Fonte: BORGER, 2002, p. 445.
${ }^{51}$ Palavras de Hertzl escritas no seu livro Derem Judenstat escrito 14/02/1896 quer dizer "O Estado Judeu"ou em alemão também pode significar "O Estado dos Judeus", com o subtítulo: "Tentativa de uma Solução Moderna para o Problema Judeu”. (BORGER, 2002, p. 443). 


\subsubsection{Korczak e o Sionismo}

Nos anos entre 1899 e 1900, Korczak conheceu, na universidade, Isaac Grinboim, um jovem ativista sionista que também era estudante de medicina e tentou influenciá-lo com ideias sionistas. Grinboim (1956, p.58 apud SCHNER, 2005, p.40) escreveu em seu livro sobre os tipos de jovens judeus como Korczak que eram assimilados à cultura polonesa e encobriam sua identidade judaica. Korczak, por amizade a Grinboim, começou a participar de encontros semanais na casa de Nachum Sokolov ${ }^{52}$, onde se reuniu com pensadores sionistas, socialistas e simpatizantes do Bund ${ }^{53}$. Nessas reuniões, discutiam sobre diversos assuntos relacionados à situação judaica em Varsóvia e na Europa. Eram encontros estudantis (SHARSHEVSKI, 1990, p.30, apud SCHNER, 2005, p.40) em que as palestras eram proferidas nas línguas iídishe, polonesa, russa e alemã, e Korczak era um dos palestrantes.

Segundo Shevakh Éden (2000, p.73), Korczak participava das festas promovidas para I L Peretz ${ }^{54}$ e lá conheceu os melhores escritores da literatura iídishe da Polônia como Shalom Asch ${ }^{55}$, Shloyme Zanvl Rappaport ${ }^{56}$ e Haim Nachman Bialik ${ }^{57}$.

Alternadamente, fazia parte da Intelligentsia ${ }^{58}$ polonesa na Flying University ${ }^{59}$, onde se encontrava com os estudantes e professores intelectuais da sociedade de Varsóvia e eram discutidos os problemas nacionais. Sua participação na vida judaica e na polonesa tornou-se interligada a partir desta época e aparece sua sensibilidade aos problemas enfrentados pelas crianças judias. Nesse sentido é importante ressaltar que, nos seus artigos, ele se definia como um polonês-judeu (SHARSHEVSKI, 1990, p.30, apud SCNHER, 2005, p.40).

\footnotetext{
${ }^{52}$ Nachum Sokolov foi Líder sionista polonês (1859-1936), autor e tradutor em língua hebraica moderna. De 1931 á 1935 foi presidente do Congresso Sionista Mundial. Foi o primeiro a traduzir o livro Alteneuland-O Estado Judeu de Theodor Hertzl, (1860-1904), fundador do Sionismo Político e do Congresso Sionista para a criação de um estado judaico.

${ }^{53}$ Bund: Partido político fundado em 1897, em Vilna, chamado de União Geral Operária Judaica da Lituânia, Polônia e Rússia. Tinha como objetivo unir todos os trabalhadores judeus do Império Russo, nessa região onde vivia a maioria dos judeus, para estabelecer uma democracia socialista, dentro da qual os judeus almejavam seu reconhecimento como minoria nacional. A plataforma bundista não apoiava a solução judaica sionista de um nacionalismo extraterritorial.

${ }^{54}$ Isaac Leib Peretz (1852-19150, polonês, judeu secular, escritor e dramaturgo clássico da língua iídiche que despertava em seus leitores o desejo pela autoemancipação.

${ }_{56}^{55}$ Shalom Ash (1880-1957) escritor judeu polonês nas linguas iídishe e hebraica.

${ }^{56}$ Shloyme Zanvl Rappaport (1863-1920) era conhecido sob pseudônimo S. Ansky, judeu russo, escritor, dramaturgo e pesquisador do folclore judaico.

${ }^{57}$ Haim Nachman Bialik (1873-1934) poeta russo, o pioneiro na escrita em hebraico moderno.

${ }^{58}$ Este termo foi instituído no século XIX, na Rússia, Alemanha e Polônia para designar um grupo de intelectual motivado a propagar o desenvolvimento da cultura e da busca pela liberdade individual e civil.

${ }^{59}$ Korczak participava paralelamente da Flying University,uma Universidade clandestina onde os professores e alunos intelectuais se encontravam em endereços diferentes para fugirem da vigilância da polícia. Os que eram pegos eram enviados à Sibéria. Os encontros eram para discutir os problemas da Polônia e os temas variavam entre a independência nacional ou a aliança socialista russa, mas sempre unidos e determinados a manter viva a cultura e história polonêsa. (LIFTON, 2005, pp. 34 a 37).
} 


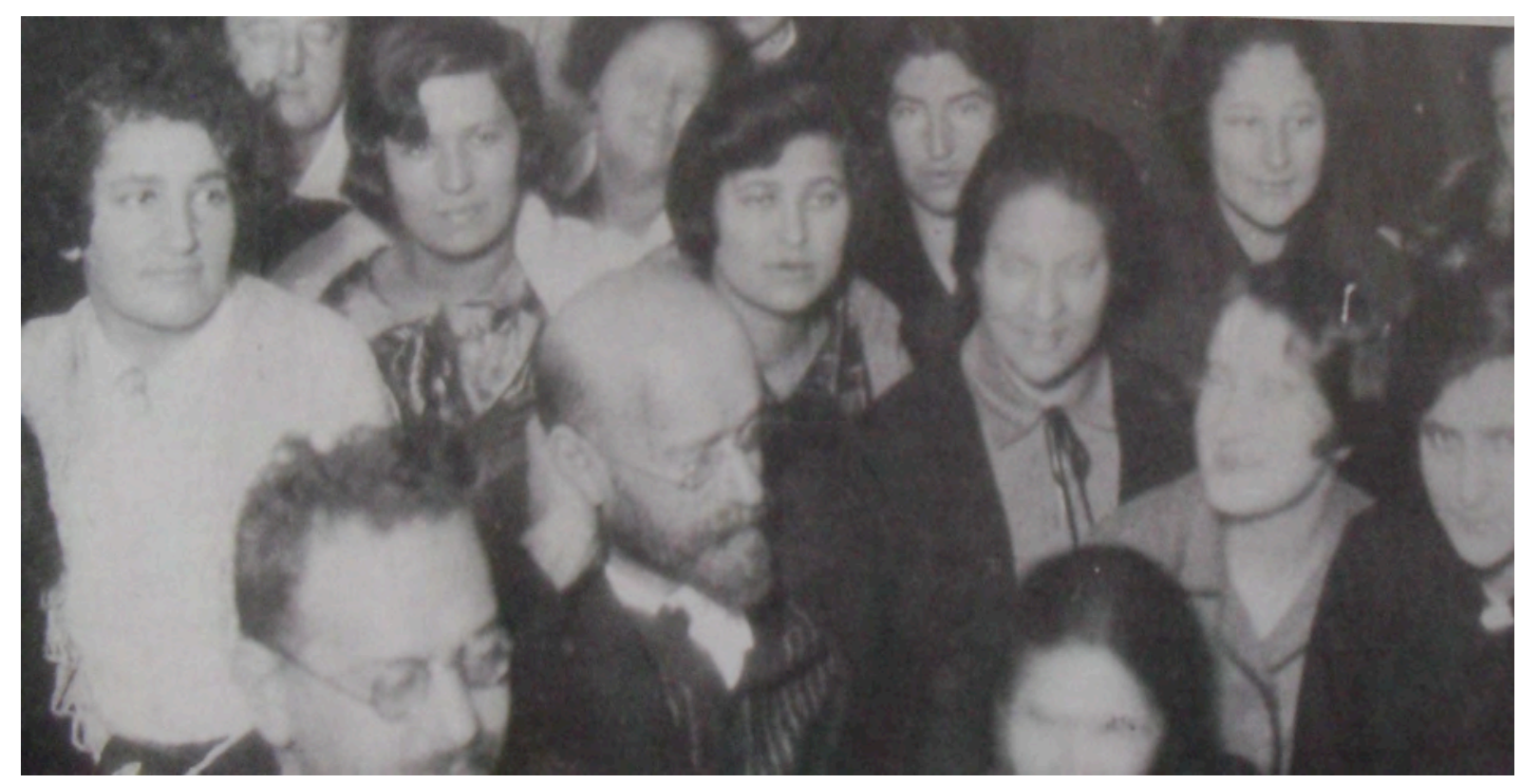

Imagem 20 - Korczak entre os educadores em um seminário para professores em Varsóvia. Fonte: Beit Lohamei Haghetaot

No orfanato, que Korczak dirigiu com Stefa, foram contratados educadores em sua maioria vinculados aos movimentos juvenis sionistas que se formavam na Polônia. Com a ascensão do sionismo e o ativismo político de Theodor Herzl mais de mil grupos sionistas foram criados e dezenas de movimentos juvenis surgiram em versões socialistas ou religiosas em países como a Alemanha, Áustria, Romênia, Tchecoslováquia, Rússia, Polônia, e Hungria.

Essas organizações juvenis tinham como finalidade pensar na criação de um novo modo de vida, diferente daquela que seus pais viviam - uma geração falsamente assimilada no Oeste e miseravelmente atolada no Leste (BORGER, 2002, p. 487). Seria uma sociedade harmoniosa, livre de injustiças e antissemitismo, na Terra de Israel. Estes jovens expressavam-se com ritos e simbolismos próprios e compartilhavam de uma camaradagem e solidariedade entre si. Os diversos movimentos chamavam-se Blau-Weiss, Kadimah, Habonim, Hashomer Hatsair, Gordonia, Bahad, Bnei Akiva, Ezra, Betar e Hehalutz.

Korczak sentiu a necessidade de criar uma instituição que oferecesse um abrigo para adolescentes maiores de 14 anos que já não eram mais atendidos pelo orfanato. Ele criou, em 1923, com o apoio financeiro da comunidade judaica de Varsóvia, o sistema da Bursa 


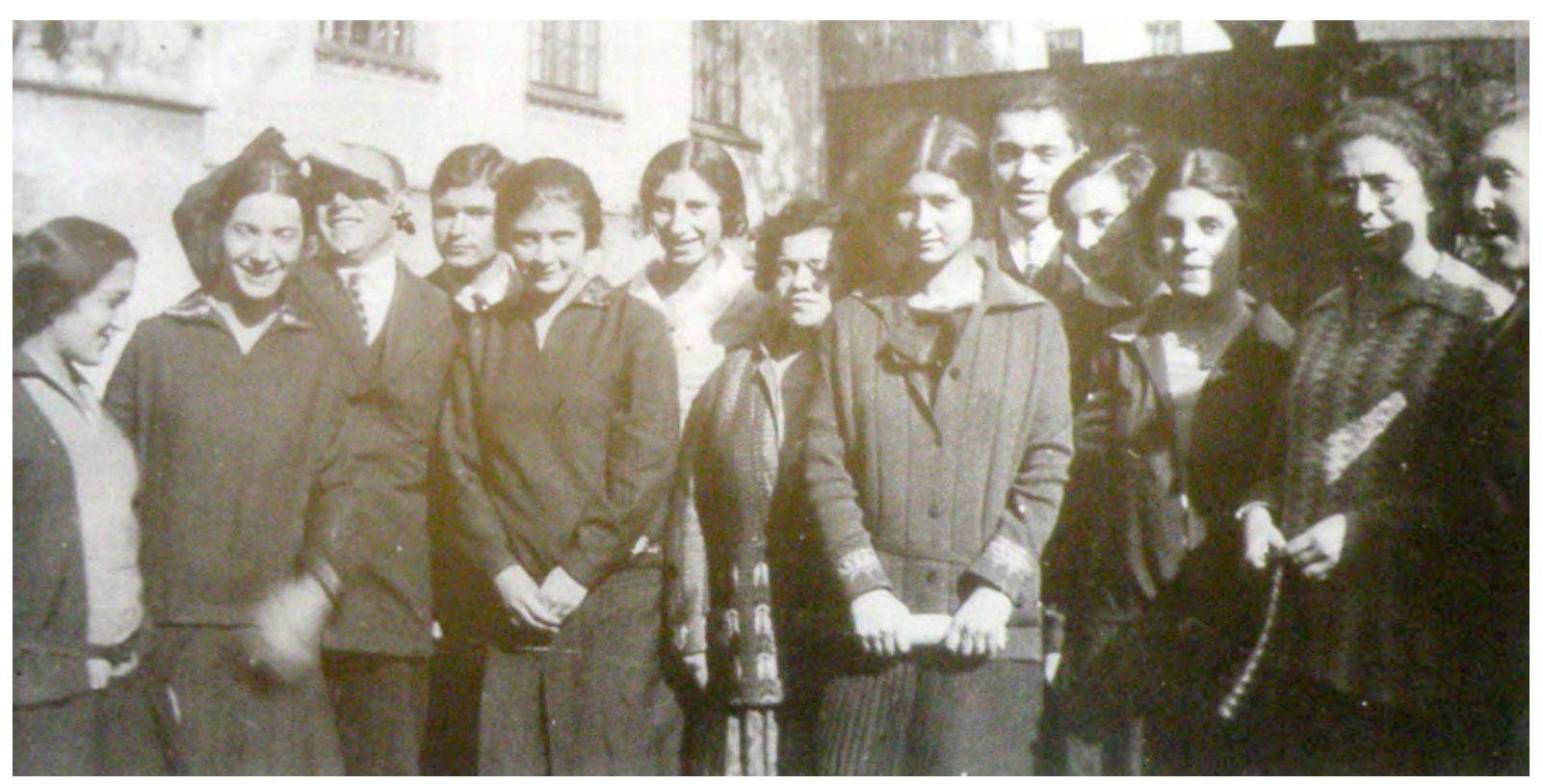

Imagem 21 - Os jovens educadores da Bursa. s/d Fonte: Beit Lohamei Haghetaot

A Bursa era um internato situado numa casa ao lado do orfanato judaico. O objetivo dessa instituição era acolher aqueles adolescentes saídos do orfanato e os jovens entre 18 e 24 anos de idade que vinham de varias regiões da Polônia com interesse na área de educação. Os bolsistas recebiam moradia e um pequeno salário em troca de quatro horas de trabalhos gerais no orfanato e conseguiam prosseguir em seus estudos profissionalizantes. Foram esses jovens educadores que introduziram ideias novas no orfanato como o estudo da língua hebraica e a ideia do sionismo.

Por influência de Joseph Arnon $^{60}$ (SHNER, 2008, p. 41), um dos educadores bolsistas do orfanato estabeleceu contato com o movimento juvenil sionista chamado Hashomer Hatzair. Entre os anos de 1924 e 1925, Korczak foi apresentado a Moshe Zertel ${ }^{61}$, um dos jovens monitores desta organização, e convidado a proferir palestras pedagógicas aos coordenadores deste movimento com sede em diversas regiões de Varsóvia. A partir desse convívio, Korczak enviou um grupo de crianças do orfanato para participar de um passeio

\footnotetext{
${ }^{60}$ Joseph Arnon (1919-2005) foi educador do orfanato entre os anos de 1929-1932. Imigrou para Palestina e foi membro do kibutz Ein Hamifratz. Durante anos trocou correspondências com Korczak entre 1932 e 1939. Dentre elas foram regatadas 13 cartas. Escreveu o livro com o título “Quem foi Janusz Korczak?’São Paulo, 2005.

61 Moshe Zertel, jovem polonês integrante do movimento juvenil sionista Hashomer Hatzair (O Jovem Guardião), imigrou para a Palestina em 1925 e se estabeleceu no Kibutz Ein Shemer. Nas duas viagens de Korczak à Palestina eles se encontram trocaram correspondências até 1939.
} 
comemorativo da festividade de Lag B $^{\prime}$ omer $^{62}$. Essa parceria se intensificou e Korczak enviou um grupo maior de crianças para participar das colônias de férias e atividades junto com o Shomer Hatzair, aproximação que, de acordo com Moshe Zertel (SHNER, 2008, p.41), deu ao orfanato um espírito diferente e especial. Isso pôde ser percebido pelo fato de que daquele momento em diante, no orfanato, junto à bandeira da Polônia, foi hasteada a bandeira azul e branca do movimento sionista e introduzido o ensino da língua hebraica.

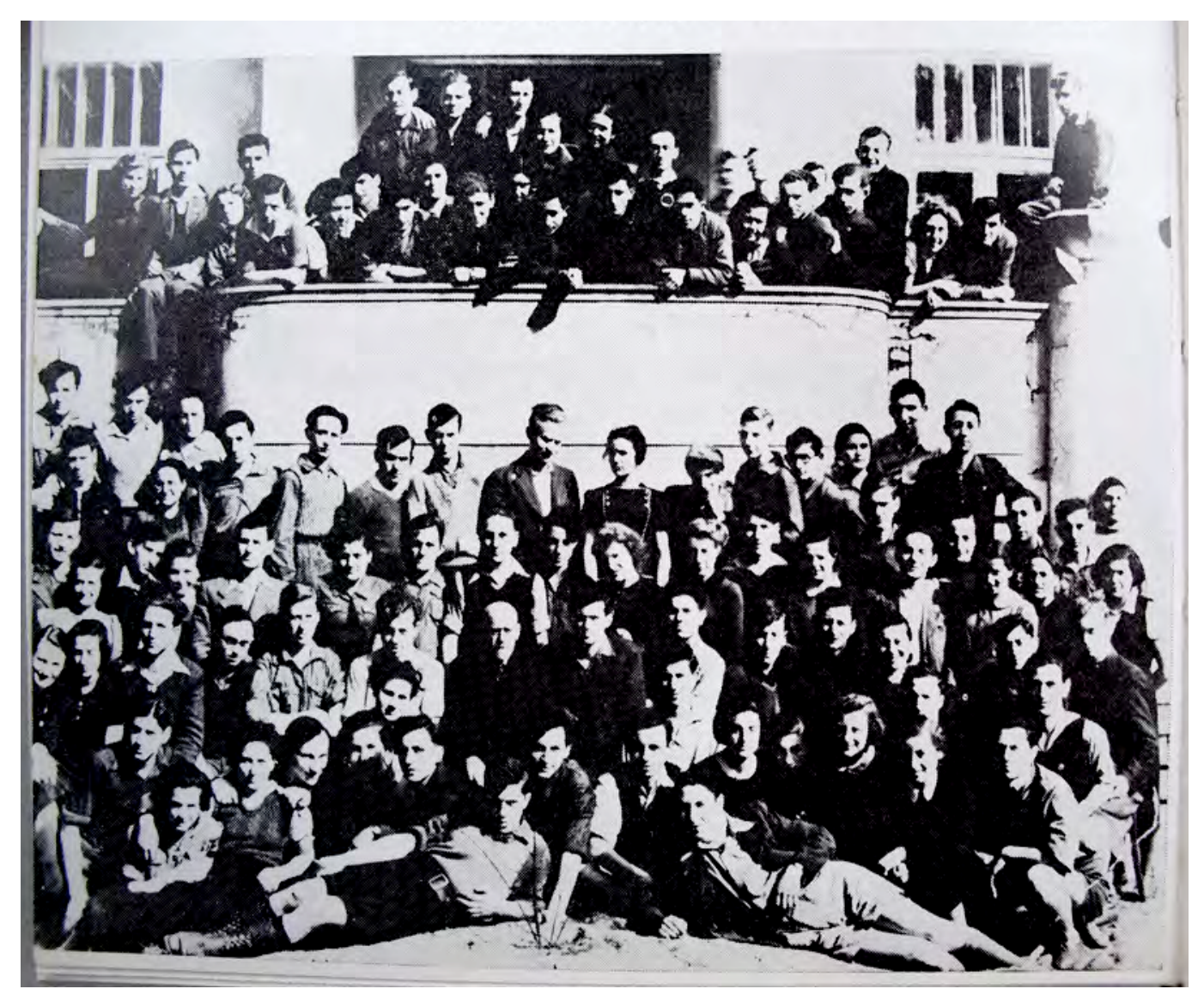

Imagem 22 - Korczak ao centro, em baixo, em 1938 no seminário de educadores do movimento juvenil judaico Hashomer Hatzair em Varsóvia. Fonte - Dat Hayeled, 1978, p. 65.

Nesse contexto, a Terra de Israel passou a ser considerada como um lugar para se morar e não apenas um pôster no mural. E Korczak passou a integrar reuniões do Shomer Hatzair, proferindo palestras aos pais de incentivo a enviarem seus filhos a participar das colônias de férias proporcionadas pelo movimento juvenil

\footnotetext{
${ }^{62}$ Festividade judaica em lembrança ao sábio Rabi Shimon Bar Iokchai (século II), fundador do Zohar, a Cabala e discípulo de Rabi Akiva(50-135), grande estudioso nos assuntos da tradição judaica. É costume acender uma grande fogueira, cantar e dançar em volta da mesma.
} 
Em 1925, chegaram à Polônia, vindos da Palestina, Menachem Osiskro e Yehoshua Manuach entre outros representantes da organização sionista "Keren Kaiemet Leyisrael- KKL (Fundo Nacional Judaico)" ${ }^{63}$, primeira ONG ambiental criada no início do século XX na Palestina. Eles foram recebidos pela Intelligentsia judaica polonesa na comemoração da festa de Lag Baomer ${ }^{64}$. Nessa ocasião, apresentaram os objetivos e estratégias do KKL na construção e reflorestamento da Palestina como futura nação judaica. Osiskro e Manuach obteveram o apoio dos líderes da comunidade e do próprio Korczak demostrando no documento publicado no boletim informativo Kol Kore.. No livro Dat Hayeled (1978, pp. 448-449), encontra-se o texto completo traduzido para o hebraico. Korczak revisou o texto final numa reunião com Yehoshua Manuach (SHNER, T. 2008, p.42), e foi nesse encontro de quatro horas que os dois conversaram sobre a Terra de Israel e o sionismo. ${ }^{65}$ Korczak perguntou a Manuach (SHNER, 2008, p. 43) qual dos seus nomes deveria assinar, se o pseudônimo ou seu nome de nascimento. Korczak optou pelo pseudônimo, demonstrando seu honesto envolvimento com a questão judaica sem receio de possíveis reações antissemitas que este fato poderia suscitar. ${ }^{66}$ A contribuição de Korczak foi amplamente reconhecida pelo KKL, um exemplo de seu envolvimento com a causa sionista.

Após esse evento, Korczak escreveu um artigo publicado na sua coluna no jornal judaico Naash Psheglond onde reforça ainda mais seu apoio à causa do Keren Kaiemet Leyisrael. Mas, segundo Sharshevski (1990, apud SHNER,T. 1998, p.43), nesse artigo, Korczak admirava a força de vontade dos pioneiros para a realização da ideia tão difícil de construção de uma pátria judaica na Palestina, porém questionava se o sionismo era um retorno à Terra de Israel ou apenas uma fuga do antissemitismo. Esse dilema o acompanhou durante sua vida e pôde finalmente ser melhor resolvido após seu encontro com a Terra de Israel.

\footnotetext{
${ }^{63}$ Fundo Nacional Judaico - KKL. Organização sem fins lucrativos, fundada em 1901 para comprar e desenvolver a terra na Palestina primeiramente otômana e posteriormente inglesa em favor do assentamento judaico. Desde sua criação, o KKL plantou mais de 240 milhões de árvores em Israel, construiu 180 barragens e reservatórios, desenvolveu 250.000 acres $(1.000 \mathrm{~km} 2)$ de terras e estabeleceu mais de 1.000 parques.

${ }^{64}$ Festividade judaica que significa o $33^{\circ}$ dia da contagem do $\hat{O} m e r$, que é um período de 49 dias que vai do dia seguinte a Pessah [páscoa judaica] até Shavuot [festa da outorga da Torá]. De acordo com a tradição judaica, a tristeza e pesar que acompanham a contagem do Ômer são interrompidos neste dia. Há duas bases para este mandamento: a primeira é que neste dia cessou a peste que surgiu entre os discípulos de Rabi Akiva, e a segunda é que nesta data ocorre o aniversário de falecimento do Rabi Shimon bar Yochai, cujos ensinamentos introduzem uma nova era na revelação e disseminação da dimensão mística da Torá, conhecida como a Cabalá. Essa festa é comemorada com muita alegria no campo e atividades ao ar livre em volta de uma grande fogueira.

${ }^{65}$ As correções de Korczak reforçam a idéia de que a Palestina representava a terra da ancestralidade do povo judeu e não apenas uma nova pátria. SHNER, 2009, pp. 22-23

${ }^{66}$ Em Yehoshua Manuakh, Encontro com Korczak, pp.2 e 3, registro do arquivo central sionista, cópia para o arquivo de Korczak no Beit Lochamei Haguetaot, registro n 302. In SHNER, 2008, pp. 42-43.
} 


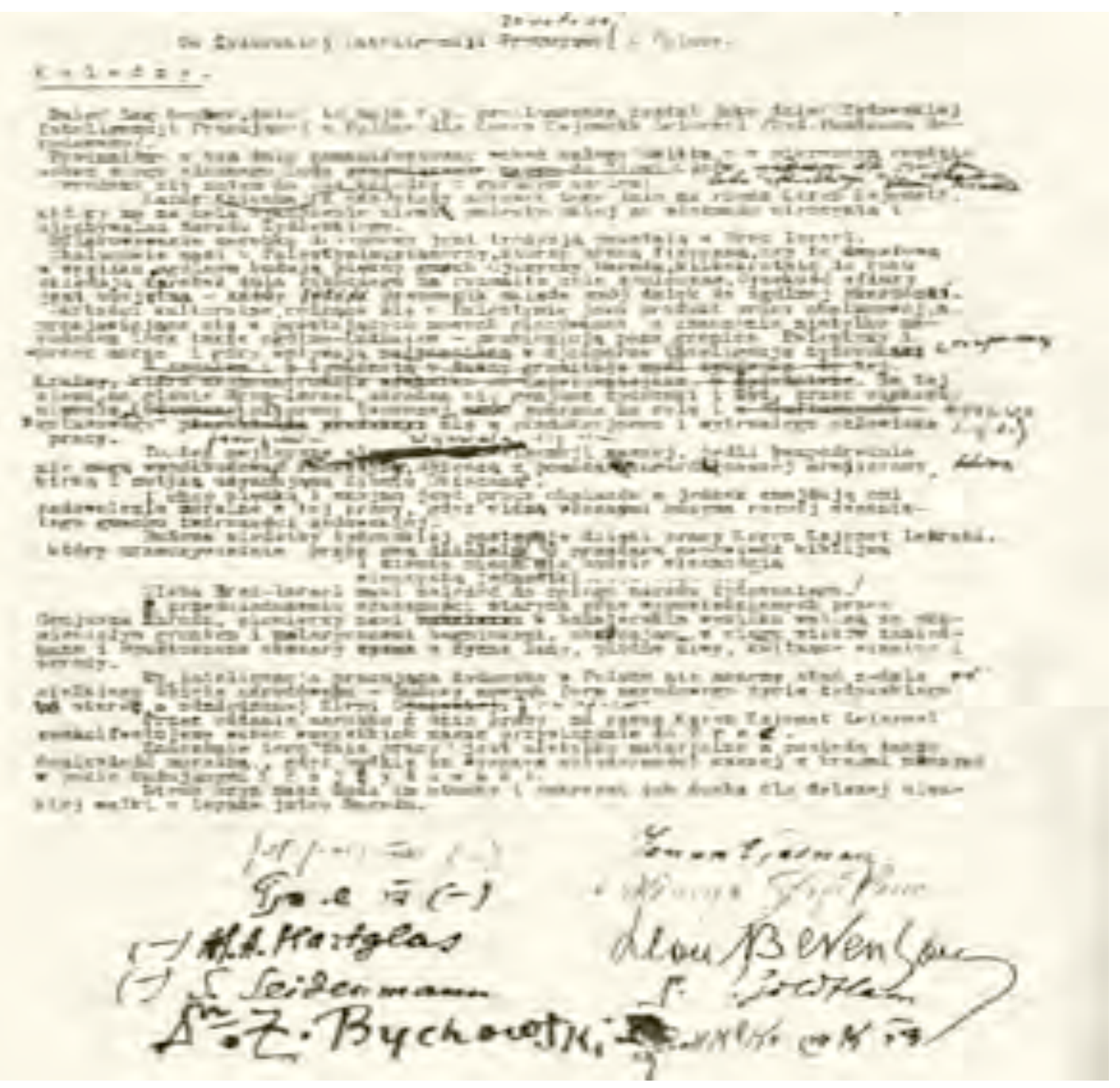

Imagem 23 - Boletim informativo do Keren Kayemet Leisrael (KKL) de 1925, contendo as assinaturas dos representantes da Intelligentsia judaica de Varsóvia com as correções escritas à mão por Korczak. A assinatura de Korczak é a primeira da coluna da direita. Fonte: EDEN, 2000, p. 247.

Korczak legitimou sua pertinência à pátria polonesa nas três guerras de que participou, sentia-se produtivo e importante para seu país. Essa percepção de seu patriotismo polonês perdurou até os últimos dias de sua vida.

Em 1939, vestiu a farda militar demonstrando sua luta individual, e usou-a até seu trágico final em Treblinka. Ao dirigir o orfanato polonês Nasz Dom (1919 a 1936), era-lhe dado o privilégio para poucos judeus dessa época de trabalhar com a comunidade polonesa. De acordo com Borger (2002, p. 483), depois da I Guerra Mundial (1914-1918), a Polônia foi reconstituída como país independente e sua população judaica atingia quase três milhões, 
10,4\% do total população (BORGER, 2002, p. 483). Os poloneses não eram tolerantes com as minorias existentes no país como os judeus, ucranianos, alemães e bielo- russos. Em contraposição ao Tratado de Versalhes (1919), que garantia proteção aos direitos nacionais das minorias, os poloneses em sua maioria tradicionalmente antissemitas não respeitaram a nova lei ${ }^{67}$. Na Polônia, em 1918 e 1919, aconteceram vários pogroms, especialmente violentos em Llov e Vilna. Os judeus sofriam de acusações antipatrióticas como, por exemplo, serem pró-ucranianos, pró-alemães e pró-lituanos. Eram discriminados pelo clero que os denunciava como inimigos do cristianismo. A Kehilá e a escola não receberam os subsídios a que tinham direito. As escolas de ensino judaico secundário não eram reconhecidas pelo ministério da Educação impedindo o acesso às escolas técnicas e universidades. E foi adotado nas universidades o numerus clausus, a restrição da participação de judeus no ensino superior. Os judeus foram sistematicamente excluídos do serviço público, de empregos nas estradas de ferro, na indústria pesada e nos monopólios estatais. O descanso sabático foi mais um motivo de interiorização na medida em que proibia os judeus de abrirem seus estabelecimentos aos domingos e nos feriados cristãos. Apenas nas cidades de Llov e Varsóvia existiu uma pequena classe judaica de posses e assimilada que vivia em bairros nobres e a língua falada era somente o polonês ou francês. Entretanto, nestas mesmas cidades, havia $34,4 \%$ de desempregados e $50 \%$ da comunidade judaica empobrecida (BORGER, 2002).

Korczak, de família rica assimilada, morou em um bairro nobre, estudou em escolas polonesas, ingressou na universidade e serviu o exército. Tinha uma visão e experiência diferente da maioria dos judeus. Ao longo de sua vida considerou essa oportunidade uma chance de realizar pela da educação das crianças um pensamento moderno com a eliminação das diferenças religiosas nas relações da sociedade adulta. Sharshevski (1996) aponta que os primeiros trinta anos da vida de Korczak foram sua fase de vida polonesa. Mas, mesmo nessa época, dizia que o pertencimento do judeu a uma cidadania polonesa era algo a ser construído com o fortalecimento dessa identidade. No orfanato judaico, enfatizava o ensino da historia da pátria polonesa para desenvolver o vínculo da cidadania. Korczak acreditava que o problema do antissemitismo poderia ser resolvido pela educação e fusão da cultura judaica e polonesa.

\footnotetext{
${ }^{67}$ A Constituição polonesa proibia discriminações religiosas, raciais ou étnicas, especificamente garantindo aos judeus escolas próprias e o respeito ao Shabat [dia do descanso semanal no judaísmo]. (BORGER, 2002, p. 48)
} 
O judeu secular, produto da Haskalá, o Iluminismo judaico motivado por Moses Mendelssohn ${ }^{68}$, almejava ser considerado como um cidadão polonês, ser aceito na sociedade e ter uma carreira profissional de sucesso. Era necessário modernizar seu estilo de vida e absorver novos conhecimentos de fora das fronteiras judaicas. A vida assimilada e popular de Korczak não se assemelhava à maioria dos judeus de Varsóvia e caracterizou-se comparativamente com a dos judeus alemães que se integraram, em sua maioria, na sociedade alemã abandonando a tradição bem como a língua iídishe.

\begin{abstract}
"Quando os Münzjuden - judeus financistas - de Frederico da Prússia ou os judeus da corte do imperador austríaco receberam, sob forma de "privilégios gerais" e "patentes", o mesmo status que, meio século mais tarde, todos os judeus da Prússia receberiam sob nome de emancipação e igualdade de direitos; quando, no fim do século XVIII, no ápice da fortuna, os judeus de Berlim conseguiram impedir o influxo dos judeus das províncias orientais ex polonesas - do império germânico, porque não desejavam dividir sua "igualdade" com os correligionários mais pobres e menos cultos, os quais não reconheciam como iguais; quando, ao tempo da Assembléia Nacional Francesa, os judeus de Bordeaux e de Avignon protestaram violentamente contra a concessão de igualdade, por parte do governo francês, aos judeus das províncias orientais - Alsácia principalmente -, ficou claro que os judeus não pensavam em termos de direitos iguais, mas sim, de privilégios e liberdades especiais." (ARENDT, 2009, p.38)
\end{abstract}

Segundo Arendt (2009, p.38), desde o século XVIII os grupos de judeus que se tornaram ricos e úteis ao Estado, gozavam de privilégios coletivos e se distanciavam de seus irmãos menos ricos e menos úteis, ainda que fosse dentro do mesmo país. Por outro lado, Korczak, aventou a possibilidade do sionismo ser uma fuga, pois, dentro de seu patriotismo, ele considerava que o cidadão deve fidelidade à pátria sob qualquer condição.

Em 1925 foi publicado no jornal judaico Alim de Varsóvia uma entrevista realizada por Yerachmiel Weingarten, jornalista e educador do orfanato judaico, (1979, pp. 195-195) com Korczak sobre a questão sionista. Esse artigo completo consta do livro de Weingarten, que foi educador bolsista do orfanato, e escreveu o livro sobre a vida de Korczak. Desta entrevista podemos contemplar algumas ideias de Korczak sobre a língua iídishe e hebraica.

"O problema das línguas será resolvido, de acordo com meu ponto de vista,
daqui a algumas décadas. Na Polônia não há futuro para o hebraico e o
iídish. A língua polonesa será dominante. Possivelmente o hebraico se
transformará- após uma determinada época - numa língua vernácula judaica

\footnotetext{
${ }^{68}$ Moses Mendelssohn (1729-1786) nascido na Alemanha, recebeu formação judaica tradicional. Considerado o precursor da Haskalá, o Iluminismo Judaico, foi filósofo e rabino do judaísmo reformista.
} 
[...] na Terra de Israel - o hebraico. Em todas as diásporas judaicas unificará o credo da língua hebraica [...]". (WEINGARTEN, 1979, pp. 193-194)

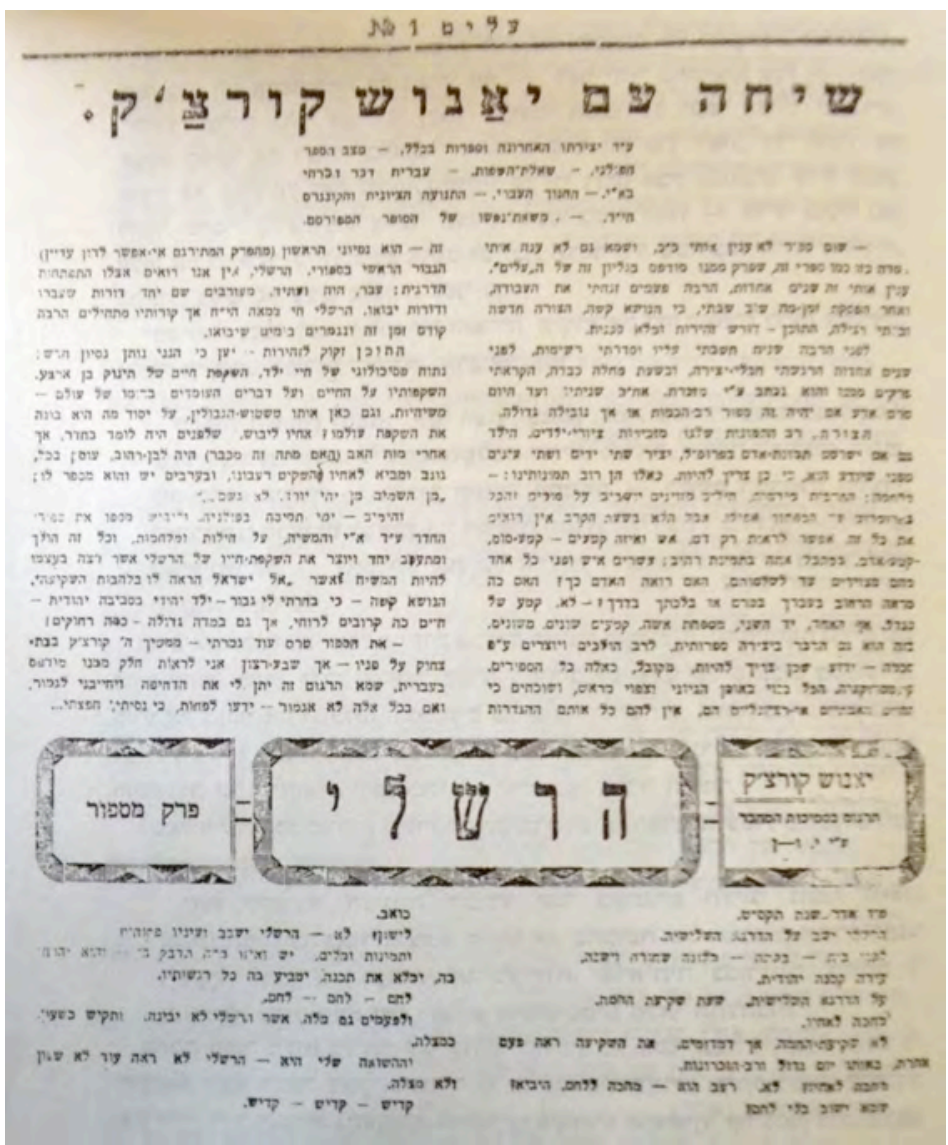

Imagem 24 - Primeira página do Alim, contendo a entrevista que Korczak concedeu a Yerachmiel Weingarten em 1925. Fonte: WEINGARTEIN, 1979, p. 193.

Na continuação da entrevista, Korczak levanta a questão da educação no kibutz, onde os bebês se desenvolviam longe dos pais durante o dia e eram cuidados comunitariamente pelos educadores. O trabalho era distribuído igualmente para homens e mulheres tanto em funções como em carga horária. O trabalho agrícola era fundamental e exigia uma longa jornada diária. Foi criado nos kibutzim um sistema próprio de educação comunitária, dividindo as crianças por faixas etárias e moradia própria. Os bebês tinham sua sede, chamada Beit Tinocot [A casa dos bebês], enquanto as crianças de idade pré-escolar ficavam sediadas no Beit Yeladim [A casa das crianças]. As crianças com idade de sete anos em diante não moravam mais com pais e só mantinham com eles uma convivência de uma a duas horas por dia. É a falta de convivência com os pais que Korczak salienta em seu artigo, observando que o novo projeto educacional só poderá ser avaliado ao longo do tempo e com o trabalho conjunto de médicos e psicólogos. 
Korczak escreveu sobre o XIV Congresso Sionista Mundial, em 1925:

Conheci o II Congresso Sionista em 1899 (na realidade era o terceiro), mas apenas fui um visitante. Era muito jovem na época [...] e minha percepção era de uma organização utópica e burguesa.

(...) Li no jornal sobre esse Congresso e me interessei bastante e quase não percebi o mesmo entusiasmo do II Congresso. Não é sinal de decadência. Sob meu ponto de vista é um sinal da saída da época utópica. Essa é uma época da ação, de cálculos e de acontecimentos. (WEINGARTEN, 1979, pp.194-195)

No período entre o III e o XIV Congresso Sionista aconteceram avanços políticos e práticos que teriam levado Korczak seu comentário sobre a falta de entusiasmo em contraposição à demonstração da ação e da administração efetiva da realização sionista. Alguns fatos importantes positivos e negativos permearam a evolução do ideal e contribuíram para a alteração de ânimos no Congresso.

Durante a Primeira Guerra Mundial, Theodor Herzl empenhou-se em estabelecer relações diplomáticas com a Kaiser alemão, a fim de conseguir apoio em favor dos judeus na Palestina já que a Alemanha tinha como aliada a Turquia, que dominava a Palestina então e poderia exercer influência política e de ajuda humanitária aos imigrantes que se estabeleceram lá. Mas foi com os ingleses que Haim Weizmann, o sucessor de Herzl, conseguiu iniciar a ideia de um Estado Judeu na Palestina. Com uma incansável atuação diplomática ele criou vínculos com colaboradores judeus e figuras importantes do governo e da sociedade inglesa em Londres. Sua amizade com Arthur James Balfour, iniciada em 1906, foi importante medida que abriu as portas para Weizman infiltrar sua ideia sionista no governo inglês. Após longos anos de diplomacia, foi assinada a Declaração Balfour, em 1917. Essa Declaração foi escrita por Balfour, Ministro do Exterior ao lorde Walter Rothschild, em nome do governo Britânico. Ela continha o apoio deste governo para o estabelecimento de um lar nacional para o povo judeu na Palestina. Após a guerra ocorreu a dissolução do Império Otomano e a Liga das Nações conferiu à Grã Bretanha, em 1922, o Mandato sobre a Palestina.

Três ondas imigratórias importantes haviam chegado à Palestina até o ano de 1925: a Primeira Aliá (1882-1903) com 25.000 russos e romenos, a segunda Aliá ${ }^{69}$ (1904-1914) com 40.000 russos e a terceira Aliá (1919-1923) com 35.183 russos, poloneses, romenos, lituanos, norte americanos e europeus em geral. (BORGER, 2002, p. 548)

\footnotetext{
${ }^{69}$ Aliá é um termo em hebraico que significa elevação, no sentido de elevar-se à Terra de Israel.
} 
A partir de 1908 intensificaram-se os confrontos na Palestina com o nacionalismo árabe. Esse conflito já havia sido despertado desde as primeiras aliot, no século XIX, em que grandes levas de judeus europeus chegaram à Palestina e compraram terras dos otomanos ou diretamente dos árabes para estabelecerem suas colônias agrícolas. Havia cerca de um milhão de árabes, em sua maioria camponeses empobrecidos dominados por poucas famílias latifundiárias e que se sentiam ameaçadas com a colonização judaica. No início do século XX, o governador e autoridade máxima sobre a Síria e Palestina, Djemal Paxá, suspeitava das intenções dos judeus, muitos cidadãos turcos, e aplicava um regime severo de controle à população do Yishuv Velho, os habitantes judeus ortodoxos que haviam se estabelecido por inúmeras gerações na Palestina e dedicavam-se à oração e ao estudo. Eles sobreviviam graças aos donativos provenientes de benfeitores da Europa, a haluka $a^{70}$. O Yishuv Novo formado pelos pioneiros, provenientes a maioria da Rússia foi considerado inimigo desde a sua chegada à Palestina, parte do Império Otomano (BORGER, 2002, p. 507).

70 Sistema de doações internacionais angariadas para o sustento de judeus ortodoxos na Palestina. 


\title{
3. Korczak e a Terra de Israel: Análise de Documentos
}

\subsection{Introdução}

O panorama histórico de caminho de Korczak ao encontro das raízes foi realizado com base na pesquisa de campo da israelense Tali $\operatorname{Shner}^{71} \cdot$. Ela refez o percurso de Korczak pela Palestina em suas duas viagens, em 1934 e 1936. Shner entrou em contato com os arquivistas dos kibutzim e moshavim com relatos de pessoas que estiveram presentes e nos registros pessoais de Korczak escritos durante as viagens e compilados posteriormente no livro Dat Hayeled (1978). ${ }^{72}$

Para acrescentar à pesquisa traremos algumas correspondências ${ }^{73}$ que Korczak trocou com seus amigos e discípulos na Terra de Israel e que Anita Novinsky descreveu do seguinte modo:

\begin{abstract}
Apesar de se escrever tanto sobre Korczak, existem ainda ângulos de sua vida que não conhecemos e que ainda estão contidos em algumas cartas, raramente mencionadas, que escreveu antes de morrer. São cartas que enviou para Israel que ele chamava de Terra de Israel, entre os anos de 1932 e 1939 endereçadas para Jusek (seu discípulo Joseph Arnon).
\end{abstract}

Essas cartas foram publicadas em Tel-Aviv em 1977 e constituem um extraordinário testemunho da época e por meio delas podemos conhecer a visão que Janusz Korczak tinha do mundo, naqueles dias sombrios. Revelam suas aflições, as desilusões com a política e os homens, o abandono e a fidelidade e amor às suas crianças. (ARNON, 2005, p. 20).

Com o intuito de estreitar os laços entre as crianças da Polônia e da Palestina Korczak publicou um artigo no jornal polonês infantil Mali Psheglond no ano de 1926, uma

\footnotetext{
${ }^{71}$ A pesquisadora israelense Tali Shner (2008, p.39) foi atrás destes registros com o objetivo de colher material sobre Korczak, seus encontros e palestras proferidas na Palestina em 1934 e 1936. Nessa pesquisa Shner se baseou nos escritos de Korczak, em suas anotações pessoais e nos registros por entrevistas.

72 Segundo Perlis, em suas duas viagens à Palestina em 1934 e 1936, Korczak visitou muitos kibutzim e moshavim como: Guenigar, Yagur, Beer Tuvi'a, Ein Harod, Guivat, Brener, Naan, Merchavia, Kfar Guiladi, Gueva e Kineret. Visitou Haifa e os Baha'im, Tiberíades e Jerusalém. As visitas de Korczak foram registradas nos diários dos arquivos desses lugares por onde ele passou e são os testemunhos para o aprofundamento das pesquisas atuais. (PERLIS, 1986, p.128-131)

${ }^{73}$ Esta pesquisa inclui além das cartas enviadas a Joseph Arnon, outras cartas enviadas a diversos amigos de Korczak na Terra de Israel.
} 
solicitação às crianças da Terra de Israel que enviassem cartas contando como eram suas vidas e seu cotidiano na Palestina.

\subsection{De 1926 a 1934}

\section{Documento $\mathbf{n}^{\circ} 01$ - Carta de Korczak para as crianças da Terra de Israel em 29/10/1926 ${ }^{74}$}

A nossa carta para as crianças da Terra de Israel é uma carta assim: "nós fundamos o jornal infantil Maali Psheglond em Varsóvia”. Não encontraremos histórias nem lendas e sim fatos que aconteceram. Queríamos que este jornal fosse escrito pelas mãos das crianças para crianças. E pelas mãos dos jovens para jovens. Os adultos dizem que é uma invenção tola, mas nós imaginamos que será bom.

Nós recebemos muitas cartas que editamos no jornal. Recebemos cartas das crianças de Varsóvia e de outras cidades. Temos cartas de Lodz, Vilna, Levov, Pozna e uma carta de Madantzig. As crianças nos enviam noticias de sua casa, escola, e tudo que quiserem. Já recebemos quatrocentas cartas.

Realmente queremos receber cartas da Terra de Israel. Porque nos pedem que escrevamos o que as crianças fazem na Terra de Israel e como são suas escolas, como trabalham nos campos e como lá estudam. Porque aqui houve uma exposição sobre a Terra de Israel muito bonita. Nós queremos conhecer sobre as maçãs e as uvas e sobre os cavalos árabes e sobre tudo.

Nós moramos muito longe e não sabemos nada, pois sobre a Terra de Israel somente os adultos escrevem para os adultos. Nós queremos saber o que acontece de verdade. Que não seja uma atitude só de fachada com detalhes supérfluos.

Também temos duas escolas judaicas e no momento muitas crianças entendem hebraico. Nós cantamos o "Hatikvah" 75 e dançamos danças típicas da Terra de Israel. Temos aqui muitos Shomrim ${ }^{76}$. Nós colecionamos selos da Terra de Israel.

Neste momento começou o inverno. Uma vez, pelo menos, caiu neve. E como é com vocês?

\footnotetext{
${ }^{74}$ Esta carta foi publicada no encarte infantil com nome de: "Mali Psheglond" [A pequena revista], no quarto exemplar do ano I do Jornal "Nasch Psheglond"; 29/10/1926, Varsóvia. (KORCZAK, 1978, pp. 377-378).

${ }^{75}$ Canção composta por Naftali Hertz Imber, em 1886, poeta inglês originalmente de Bohemia. A melodia foi escrita por Samuel Cohen, um imigrante da Moldávia. Cohen baseou-se na melodia de um tema musical encontrada em uma música do compositor checo: Bedrich Smetana Moldau. A canção tornou-se o hino do movimento sionista cantada desde o $1^{\circ}$ congresso Sionista, cantada nos movimentos juvenis judaicos e posteriormente tornou-se o hino do Estado de Israel (1948).

${ }^{76}$ Jovens integrantes dos movimentos sionistas.
} 
Não corrijam suas cartas, aqui também escrevemos com erros.

Nós queremos muito que escrevam logo. Para que antes de Chanukáh cheguem notícias da Terra de Israel.

Conhecemos aqui em Varsóvia uma menina que passou um ano na Terra de Israel. Porém é impossível que uma só menina saiba tudo, e nós queremos saber tudo.

Novamente nós pedimos cartas, porém decididamente rapidamente. Cada um sente-se e escreva imediatamente, pois depois esquecerão ou perderão a vontade.

Nós agradecemos desde já sua resposta.

Nosso endereço é: Maali Psheglond, Varsóvia, Novolipki 7.

Shalom

No outono de 1926, as crianças judias de Varsóvia conheceram o novo projeto de Korczak por uma carta endereçada a elas no jornal dos pais, Nasz Psheglond, diário judaicosionista em língua polonesa. A ideia desse encarte infantil que, editado toda sexta-feira, era para que as crianças e jovens se comunicassem entre si e falassem de suas alegrias e tristezas e a possibilidade de ajuda para resolver seus problemas. Havia 12 telefones (LIFTON, 2005, 177) à disposição na editora para quem quisesse contar sua história em vez de escrever, um jovem editor para meninos e uma jovem editora para meninas e um coordenador para vistoriar que tudo o que estava acontecendo. Um jornal para crianças feito por crianças e jovens sob a supervisão de Korczak cargo posteriormente ocupado por seu jovem amigo e secretário particular Igor Newerly (LIFTON, 2005, p.155 e 184) entre os anos de 1932 a $1939^{77}$.

O objetivo do encarte semanal do jornal era representar a criança sem fazer política e protestos. Os tópicos do jornal eram os mais diversos como futebol, filmes e viagens. Essa ideia foi bem sucedida contando com a colaboração de centenas de cartas de crianças de toda a Polônia. Havia uma coluna no jornal para crianças que queriam relatar sobre algum acontecimento antissemita. As crianças se sentiam livres para escrever, pois era um espaço totalmente voltado ao interesse da criança. Em um ano o jornal cresceu de duas para 4 páginas e contava com dois mil correspondentes ao redor do país. Havia correspondentes não judeus que denunciavam as manifestações antissemitas nas escolas completando a intenção de Korczak de agregar as crianças judias e polonesas e dar a chance de as crianças judias interagirem e desenvolverem seu vocabulário na língua polonesa.

\footnotetext{
${ }^{77}$ Igor Newerly (1903-1987), jovem polonês que foi secretário particular de Korczak por dois anos antes de se mudar para o orfanato e trabalhar na Bursa como professor de carpintaria em 1928, com 25 anos. Ele salvou o diário de Korczak do Gueto de Varsóvia, em 1942.
} 


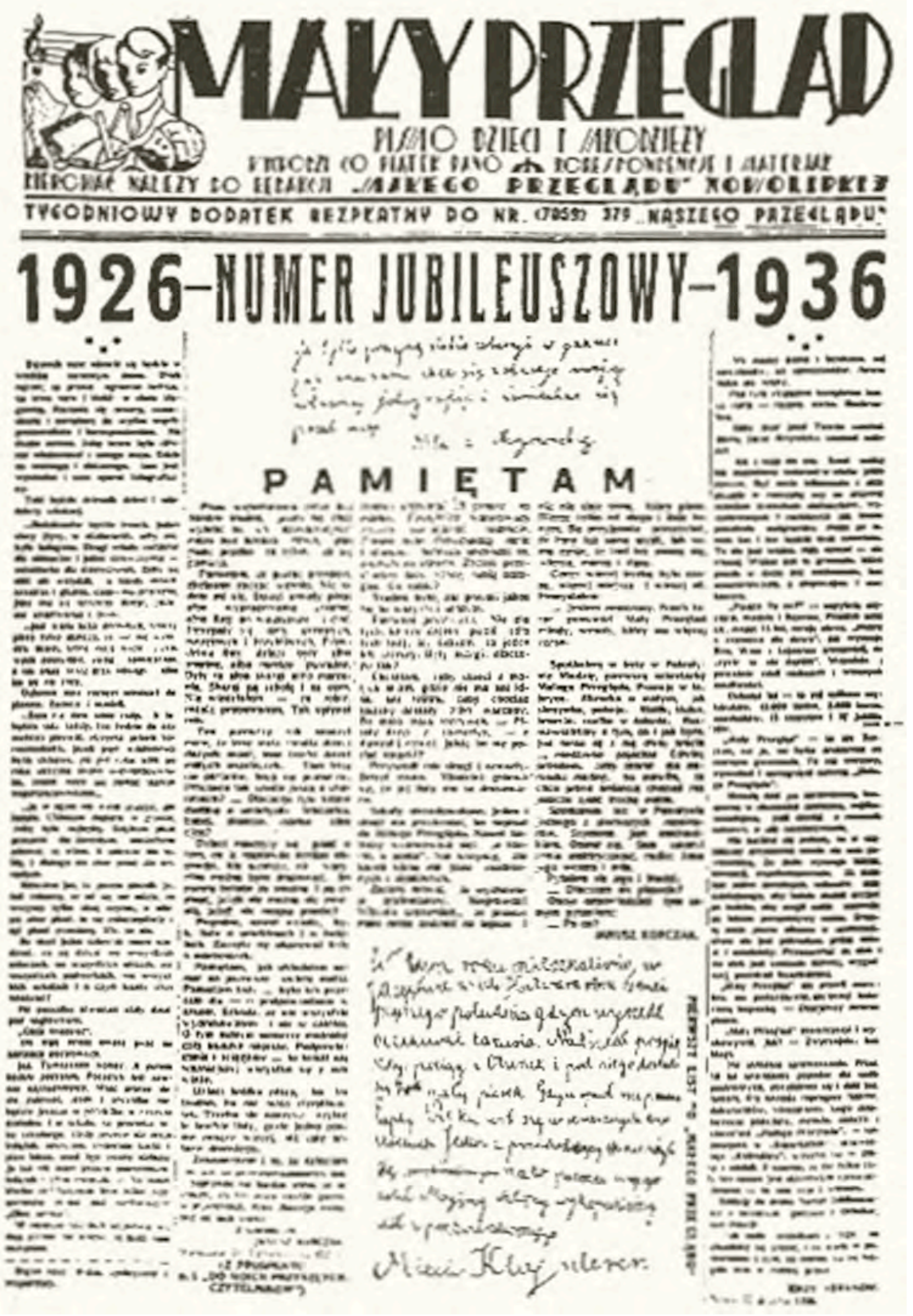

Imagem 25 - Primeira página do encarte infantil Maly Psheglond em 1936. Fonte: EDEN, 2000, p. 76.

Korczak publicou em seu livro Diário do Gueto (1986) a afirmação de que as duas primeiras décadas do século XX foram os mais profícuos de sua vida:

Eu te amo verde Vístula ${ }^{78}$. Eu não te trocaria pelo orgulhoso Thames, o turbulento Niágara, o mágico Ganges. Estes talvez sejam cem vezes mais bonitos, mas falariam comigo uma língua que eu não entenderia. Nestes anos em que o mundo era ainda o mundo intacto que ele conhecia, Varsóvia era ainda a Varsóvia cosmopolita e acolhedora (LIFTON, 2005, p.176).

\footnotetext{
${ }^{78} \mathrm{O}$ rio mais longo da Polônia.
} 
Essa descrição de Varsóvia demonstra a singularidade do perfil de Korczak diante da maioria dos judeus de sua época. Diferentemente da maioria da comunidade judaica, Korczak desenvolveu-se como profissional, criando espaços para as crianças, como o encarte no jornal. Sua reputação como educador e escritor já estava amplamente divulgada e sua produção literária desenvolvida. Os dois orfanatos que ele dirigiu Dom Sierot, com Stefa Wilsinska, e o Nasz Dom, com Marina Falska já tinham uma estrutura estabilizada e funcionavam num modelo de autogestão.

Em 1925, publicou seu livro Quando eu voltar a ser criança, um marco em sua vida, transformando Korczak escritor em Korczak educador. O texto escrito em primeira pessoa descreve a insatisfação de um professor do ensino fundamental, cansado de seus problemas de adulto e da docência. Numa determinada noite, um gnomo atende a seu desejo e realiza seu pedido de voltar a ser criança. Assim, o professor torna-se criança novamente, mas conserva a memória de adulto. Os dias que passa como menino são revelados no livro à luz das injustiças, medos e silêncios sofridos pela criança. Tatiana Belinky, autora da apresentação à edição brasileira, escreveu as seguintes palavras:

\footnotetext{
Os exemplos são muitos neste livro tão cheio de compreensão da alma infantil, de ternura e delicado humor - um livro aparentemente dirigido às crianças, mas que de fato se dirige aos adultos, pais, mestres, parentes, educadores - e coloca diante deles um espelho impiedoso, mas capaz de abrir os olhos, ainda que seja apenas os dos menos emperdenidos... Só por isso já valeria a pena lê-lo. Mas não só por isso: Quando Eu Voltar a Ser Criança é também uma leitura amena e agradável, em que pese a seriadade e importância do seu conteúdo. (BELINKY apud KORCZAK, 1981, p.10).
}

No encarte semanal infantil "Mali Psheglond" do jornal Nash Psheglond, Korczak apresentou sua posição pró-sionista. Num registro anterior a este, percebe-se que ele pretendia dar uma conotação de natureza sionista logo no primeiro exemplar do encarte. Antes dessa publicação, Korczak já havia escrito do seguinte modo no primeiro volume da primeira edição:

\section{Documento 02 - Carta de Korczak enviada às crianças da Terra de Israel em 6/10/1926:}

Da Terra de Israel chegam notícias tristes. O trabalho é escasso, muitos encontram dificuldades e gostariam de voltar. Alguns até voltaram. Todavia 
os shomrim não pensaram nisso quando decidiram fazer alia ${ }^{79}$ para a Terra de Israel, e muitos deles estão aprendendo o trabalho agrícola. Dos lugares mais distantes da Polônia chegaram a Varsóvia trezentos Shomrim de idade avançada. Decidiram imigrar ${ }^{80}$ o mais rápido possivel para Terra de Israel.

KORCZAK, 1978, p.363.

O referido artigo demonstra o interesse de Korczak pelo estilo de vida das crianças na Terra de Israel. E pelo fato de se tratar de um encarte infantil num jornal voltado à comunidade judaica polonesa, pressupõe a intenção de Korczak em estabelecer vínculos entre as crianças da Polônia e de Eretz Israel.

O desejo de troca de correspondências entre as crianças da Terra de Israel e as crianças do orfanato realizou-se após a imigração de duas educadoras do orfanato para Palestina, Ester Budko Gad, em 1925, e de Feiga Lipshitz, em 1927, para o kibutz Ein Harod, ambas amparadas pela Bursa. Feiga era educadora do orfanato e muito próxima de Stefa. Corresponderam-se até que, após dois anos, Stefa foi visitá-la em Ein Harod. Ambas aproximaram o cotidiano no kibutz e o sistema educacional praticado por meio das inúmeras correspondências com seus colegas educadores da Bursa e com as crianças do kibutz com os do orfanato. Porém, a maior parte dessa correspondência, de acordo com Lifton (2005, p.386), foi destruída por Feiga pouco antes de sua morte. Dos fragmentos das páginas restaram apenas alguns que estão sem data, e se encontram arquivados no Beit Lohamei Haguetaot, centro do arquivo de Korczak em Israel. Ele apresenta nesse artigo o envolvimento das crianças do orfanato com assuntos sionistas revelando que a língua hebraica, o Hatikva e as danças típicas já estavam sendo praticadas em seu orfanato e movimentos juvenis. Ele anuncia neste artigo uma disposição em aproximar cada vez mais esses assuntos pedindo mais informações sobre o trabalho agrícola praticado no kibutz. E também conta que há muitos integrantes do movimento juvenil sionista em Varsóvia, os shomrim [guardiões], ou seja, jovens que estavam em contato direto com atividade sionistas em seu cotidiano com pretensões futuras de serem os halutzim [pioneiros] na Palestina.

\footnotetext{
79 Termo religioso que significa o retorno à Terra de Israel, fazendo alusão a uma elevação espiritual; Aliá: [subida].

${ }^{80}$ A palavra utilizada em hebraico para imigração foi laalot, ou fazer aliá que significa elevar-se. Na conotação bíblica, aquele que imigra á Israel faz uma escolha de elevação espiritual.
} 

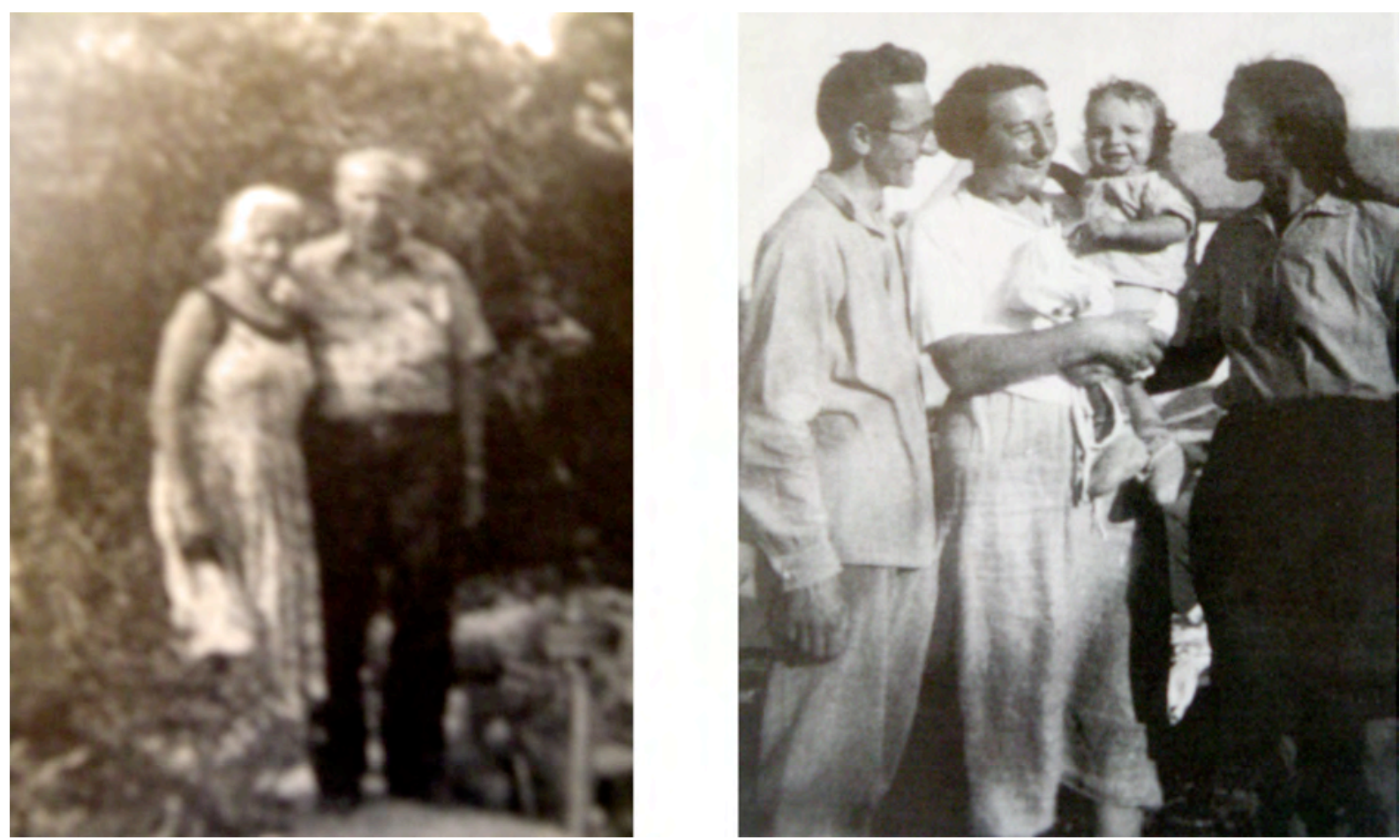

Imagem 26 - Na fotografia à esquerda, Ester Budko Gad com Yerachmiel Weingarten no Kibutz Ein Harod em 1977. Na fotografia à direita, Stefa, entre a família de Feiga Lipshitz no Kibutz Ein Harod na década de trinta. Fontes: WEINGARTEN, 1979, p. 204(esquerda) e Beit Lohamei Haghetaot (direita).

Com essas informações, pressupõe-se que Korczak queria que as crianças da Terra de Israel percebam que já existem muitos elementos em comum entre elas facilitando a comunicação. Korczak recebeu apenas duas cartas e dois meses depois, em seus registros escreveu que as crianças provavelmente queriam começar uma nova vida e esquecer-se do passado difícil (KORCZAK, 1978, pp. 378-379).

\section{Documento $\mathbf{n}^{\circ} 03$ - Carta de Stefania Wilczinska enviada a Feiga Lipshitz em 1930. $^{81}$}

Eu teria me sentido muito mal se tivesse ido com você [...] Você sabe muito bem o que significa uma mãe. Mas agora estou disponivel para fazer planos. Meu irmão e minha irmã não precisam de mim e o orfanato pode continuar funcionando muito bem na minha ausência. Eu tenho coragem de dizer a mim mesma que quarenta e quatro anos é o começo da terceira idade. Estou exausta. Meus nervos ainda estão quentes da guerra. Eu preciso de um trabalho calmo. Estou cansada e solitária. O Doutor enfiado lá em cima, distante. A questão é que, de fato, ele está escrevendo um livro. Não é fácil sem ele.

\footnotetext{
${ }^{81}$ Carta de Stefa para Feiga datada de 1930, encontrada numa mala na casa em baixo da cama de Feiga após seu falecimento. Muitas cartas de Stefa estavam destruídas e os fragmentos legíveis, muitos sem data, estão arquivados no kibutz Ghetto Fighthers' House.
} 
Nessa carta, Stefa demonstra o cansaço pelo trabalho de anos consecutivos de entrega pessoal. Sua ligação com Feiga, uma garota de dezessete anos de idade, recém chegada de uma pequena cidade da Rússia, tornou-se íntima, como mãe e filha logo que se conheceram. Feiga foi estudar no seminário para professoras de crianças pequenas em Varsóvia onde Korczak lecionava. Entre 1923 e 1924, foi integrante da Bursa, trabalhou por um ano como educadora em Bielistoc e depois retornou ao orfanato de Korczak. Em 1927 imigrou para Palestina e formou sua família no kibutz Ein Harod (KORCZAK, 1978, p. 431). Stefa havia planejado viajar junto com Feiga para ajudá-la na adaptação à nova terra. Quando sua mãe adoeceu, desistiu da ideia. Sobre a colocação de Stefa de que o orfanato seguiria normalmente com a ausência dela era questionável, pois ela era a mãe de todos, possivelmente até de Korczak. Muitos educadores aprendiam com Stefa principalmente com seu método de organização (LIFTON, 2005, p. 161).

Itzkhak Belfer ${ }^{82}$, aluno do orfanato, relatou que sabia quando Stefa estava por perto com seu molho de chaves anunciando sua chegada. Ela parecia "um navio atravessando o oceano. Para a maioria dos órfãos ela era o coração, o cérebro, a enfermeira e mãe. Ele contou que Stefa se ausentava apenas uma noite na semana para visitar a família e só recebia a visita de seu irmão no orfanato. Korczak era como o pai de todos, entretanto sempre ocupado, e Stefa, a mãe, sempre presente. ${ }^{83}$ (LIFTON, 2005, p. 160).

Em 2005, a professora Ana Szpiczkowski foi a Tel Aviv entrevistar Itzkhak Belfer, artista plástico reconhecido em Israel. Belfer pertencia a uma família de seis irmãos criados somente pela mãe que, por falta de condições de manter a todos, levou o menino para o orfanato aos sete anos de idade. Belfer lembra-se das responsabilidades das crianças, dos critérios de contratação dos educadores, dos direitos iguais para adultos e crianças, dos plebiscitos, dos tutores que recebiam os recém-chegados, do acolhimento de Korczak, das apostas para a mudança de comportamento, do Tribunal. Lembra-se também das crescentes dificuldades, mas no orfanato ressalta: "Não é utopia ou lenda. Lá não tínhamos medo de nada". Belfer ficou no orfanato até os quinze anos, quando a secretária conseguiu arrumar-lhe um emprego. Os egressos do Lar das Crianças gozavam, segundo ele, de boa fama, tanto no

\footnotetext{
${ }^{82}$ Nascido em 1923 em Varsóvia foi aluno do orfanato de Korczak entre 1930 e 1938. Em 1939 fugiu para União Soviética e foram enviados a trabalhos forçados em minas de carvão nos Montes Urais. Em 1946 voltou para Polônia e embarcou no navio de imigração ilegal Af Al PI Chen, que foi interceptado pelos ingleses e ficou preso num acampamento em Chipre. Lá estudou desenho e escultura com Zeev Ben Zvi e, em 1949, emigrou para o Estado de Israel. Ele estudou no Instituto Avni de Arte e Design e participou de muitas exposições em Israel e exterior e atualmente reside em Israel. Fonte: Site do Yad Vashem, http: www. yadvashem.org. il: Virtues of Memory, Six Decades of Holocaust Survivor's Creativity, 8/5/2011, 23:58 hs

${ }^{83}$ Entrevista realizada por Lifton com Belfer em Tel Aviv 1981.
} 
mercado de trabalho quanto nas outras escolas nas quais continuavam os estudos, porque "sua capacidade de aprender era mais desenvolvida que a dos outros". Além de auxiliar a conseguir emprego, o Lar das Crianças deu-lhe, com base em decisão do Parlamento, uma bicicleta para que pudesse chegar ao trabalho. De suas lembranças do tempo do orfanato, Belfer ressalta o aprendizado da responsabilidade social e individual: "Eu sabia onde estava e o que deveria fazer em cada situação. Tínhamos autonomia completa, e isto causou auto-estima, respeito e amor-próprio elevados”. (SZPICZKOWSKI, 2006 apud SINGER, 2010, p.83)

Em 1931, Stefa viajou à Palestina ao encontro de Feiga e ficou hospedada por três meses no kibutz Ein Harod. Trabalhou no berçário e, quando retornou à Polônia, reportou a Korczak sobre o sistema experimental de educação realizada no kibutz. As crianças viviam em casas separadas dos pais desde bebês, possibilitando às mulheres trabalhar nos campos junto com os homens. Stefa iniciou os estudos em língua hebraica no orfanato, com o propósito de retornar à Palestina, influenciando Korczak a fazer o mesmo.

\section{Documento ${ }^{\circ} 04$ - Carta de Korczak enviada a Ester Bodko Gad ${ }^{84}$ em 27/01/1928}

À jovem ilustre Esterica,

Sua última carta, minha senhorita, foi um importante documento que me confirma o que eu pensava a respeito do trabalho aí desenvolvido. Muita ingenuidade e uma grande ilusão juvenil. E, portanto, tantas frustrações amargas ligadas à Terra de Israel. Quando acabar a empolgação e os discursos, vai surgir o desconforto vai aparecer à tênue realidade. "Rasgado" de sua terra, ambientado com a terra da neve, do pinho e do exílio tanto físico, quanto moral. A busca de união entre as duas pontas da corda rompida há dois mil anos é um assunto difícil. Ela será bem sucedida porque assim exige a história, apesar de tanto esforço e sofrimento. (KORCZAK, 1978, p.175)

Nesse trecho da carta, Korczak anuncia sua preocupação pessoal sobre as dificuldades de viver na Terra de Israel. Ele era um cidadão polonês, vinculado à língua e cultura do país e a seu trabalho com os órfãos. Apesar disso, tinha uma empatia pelos jovens sionistas dispostos a deixar a terra natal por um lugar desconhecido e muito diferente da Polônia. Alguns desses jovens pioneiros haviam trabalhado com educadores ou eram alunos do orfanato.

${ }^{84}$ Ester foi educadora do orfanato dirigido por Korczak e emigrou para a Eretz Israel em 1925 tornado-se membro do Kibutz Ein Harod. 
De acordo com Shner (2008, p. 21), nesta carta Korczak ressalta que, depois de tantos anos vividos na diáspora, seria difícil recuperar a ligação com a "velha e nova Terra", e que poderia levar anos para acontecer essa adaptação. Korczak refere-se à Terra velha, como a dos tempos bíblicos e à nova como o ideal de construção dos jovens pioneiros. No entendimento de Korczak, o jovem que sai da terra natal leva consigo a dor da perda da pátria e tudo que a envolve, como a cultura, os costumes, a vegetação e o clima. Em conseqüência disso, os jovens na Terra de Israel poderiam se sentir numa diáspora, portanto tinham um desafio diário para superar essa adaptação no dia a dia. Para a concretização do ideal, os jovens precisavam enfrentar as dificuldades no cotidiano e sublimá-las em favor da realização do ideal.

Nesse sentido, quando Korczak se refere a uma ilusão juvenil, ele sustenta a ideia de que os jovens, determinados e comprometidos com seu ideal, poderiam não estar preparados para enfrentar os problemas diários, numa terra árida e desprovida das facilidades de um país já constituído como a Polônia.

Quando Korczak se refere ao exílio físico e moral dos jovens rasgados de sua terra natal, demonstra preocupação com a ruptura da identidade imposta pelo regime antissemita aos cidadãos da Polônia. Todorov descreveu uma experiência similar quando deixou seu país natal, a Hungria, para ir estudar e morar na França. Em seu livro O Homem Desenraizado (1996), Todorov afirma que não era um estrangeiro na França, porém isso não o tornava um francês:

O homem desenraizado, arrancado de seu meio, de seu país, sofre em um primeiro momento: é muito mais agradável viver entre os seus. No entanto ele pode tirar proveito de sua experiência. Aprende a não mais confundir o real com o ideal, nem a cultura com a natureza: não é porque os indivíduos se conduzem de maneira diferente que deixam de ser humanos. Às vezes ele fecha-se em um ressentimento, nascido da hostilidade dos anfitriões. Mas, se consegue superá-lo, descobre a curiosidade e aprende a tolerância. Sua presença entre os "autóctones" (nativos) exerce por sua vez um efeito desenraizador: confundindo com seus hábitos, desconcertando com seu comportamento e seus julgamentos, podem ajudar alguns a engajar-se nesta mesma visão de desligamento com relação ao que vem naturalmente através da interrogação e do espanto. (TODOROV, 1996, p.27)

Traçamos um paralelo da metáfora do homem comparado a uma árvore. O homem, como a árvore, possui raízes que o prendem a terra em que nasceu. E por mais que o desejo de sair e trocar de terra lhe sejam importantes, sofrerá as consequências da mudança. No período 
entre guerras, os judeus saíram de seus países de origem à procura de novas oportunidades. Segundo Maria Luiza Tucci Carneiro (2010), o judeu tornou-se um cidadão do mundo, mas foi transformado no principal alvo das revoluções nacionais ocorridas em diferentes países. $\mathrm{O}$ judeu perdeu sua "personalidade" ficando sem direitos e deveres para com a pátria-mãe, que se tornou indefinida. Essa "personalidade" reduziu-se à categoria de sub-humana. Existe, nesse contexto, uma diferença entre Korczak e Todorov e a grande maioria dos judeus que saíram à procura de um país que os adotasse como cidadãos. Ambos, como pertencentes à elite, puderam escolher o novo destino para abandonar o regime totalitário a que eram submetidos. E mesmo com o privilégio da possibilidade de escolha, a nova pátria era um desafio à adaptação e um exercício de tolerância às diferenças. A grande maioria dos judeus que haviam sido perseguidos e humilhados pelo Estado nazista não tinha para onde ir, e as nações não os queriam como cidadãos.

Retornando à missiva entre Korczak e Stefa, sabe-se que ela viajou em 1931 para Ein Harod e se hospedou na casa de Feiga. Lá ficou por três meses, trabalhando no Beit Yeladim [casa das crianças], onde os bebês eram cuidados desde o nascimento enquanto seus pais trabalhavam em igualdade de direitos por todo o dia. Ela deu sugestões de abaixar as pias ao nível das crianças e fazer nós nas pontas das toalhas para facilitar sua utilização. Às vezes ela trabalhava junto coma Feiga e ambas davam conselhos sobre a conduta pedagógica de Korczak. (LIFTON, 2005, pp. 202-203).

Korczak, durante esses anos até sua decisão de viajar pela primeira vez à Terra de Israel, em 1934, refletiu detalhadamente sobre cada aspecto que envolvia a viagem. A ideia da visita se intensificou na época que o poeta polonês Antoni Slonimski ${ }^{85}$ definiu como "A época difícil e da grande vergonha". Nos anos do governo do Marechal Pilsudski (a "Ditadura Moralizadora", de 1926 a 1935) dois novos poderes ameaçadores da segurança da Polônia ergueram-se ao oeste e ao leste. Em 1933, o nacionalista radical Adolf Hitler assume o poder na Alemanha, com explícitos planos expansionistas (o que implicava o reclamo dos territórios alemães cedidos à Polônia pelo Tratado de Versalhes, de 1919). Em 1934, Stalin assegurou definitivamente sua liderança total sobre o Estado Soviético, por ocasião do chamado "Congresso dos Vencedores", ampliando o projeto de transformar a URSS numa grande potência.

\footnotetext{
${ }^{85}$ Antoni Slonimski (1895-1976) nasceu em Varsóvia e foi poeta, jornalista, dramaturgo, e conhecido por sua dedicação à justiça social. Em 1919 ele co- fundou a Skamander, grupo de poetas experimentais com Julian Tuwim e Jaroslaw Iwasskiewicz. Em 1924, viajou para a Palestina e para o Brasil.
} 
Os acontecimentos na Alemanha, com a ascensão do nazismo e a visita de Goebels ${ }^{86}$ em Varsóvia, fortificaram a facção direita radical antissemita na Polônia. Tudo isso mais o convite de Goering ${ }^{87}$ para visitar Varsóvia criou uma sensação de frustração e desânimo em Korczak. No final de 1933, os dirigentes da oposição polonesa, KPP- partido polonês tinham um projeto de reunir os setores sociais insatisfeitos com a opressão do regime militar. O KPP fez aliança com setores não-marxistas e automaticamente aborreceu Stalin que dissolveu o partido sob acusação de infidelidade. (Marangon, 2007, p.79) Em 1934 surgiu um movimento nacionalista radical que levantava a bandeira nazista. A onda de antissemitismo começou nas universidades em 1930 e aumentou os ataques contra os judeus e a esquerda polonesa.

Neste período Korczak escreveu para seus amigos na Palestina e descreveu nas cartas sua reflexão sobre os acontecimentos desta época:

\section{Documento $^{\circ} 05$ - Carta de Korczak enviada a Joseph Arnon ${ }^{88}$ em 08/10/1932 \\ Se existe um país, onde é oferecida a chance honestamente à criança para expressar seus sonhos e temores, suas aspirações e suas perplexidades - possivelmente é em Eretz Israel. Lá deveria ser erguido um monumento ao órfão desconhecido [...] \\ (...) Não perdi a esperança de passar meus últimos anos em Eretz Israel e lá sentir saudades da Polônia.}

Goldszmit

(ARNON, 2005, pp. 77-78)

Neste trecho notamos a visão sionista de Korczak ao se referir à Palestina como um país. Nessa época, A Terra de Israel, a Palestina de então, estava sob domínio do Governo Britânico. Desde a Quarta Aliá (1924-1932) a imigração era formada por judeus poloneses de classe média que não toleravam mais as medidas econômicas antijudaicas implementadas na Polônia. O governo estatizou a maioria das empresas industriais e comerciais, substituindo a mão de obra judaica pela polonesa. A imigração aos Estados Unidos foi limitada (ARNON, 2005, pp. 77-78), portanto esta Aliá levou oitenta mil poloneses, somando um total de

\footnotetext{
${ }^{86}$ Joseph Goebbels, (1987-1945) nasceu em Berlim e inscreveu-se no Partido Nazista ocupando o cargo de chefe da propaganda nazista.

${ }^{87}$ Herman Goering (1893-1946) foi um político e militar alemão, membro do Partido Nazista, Marechal do Reich, comandante da Luftwaffe e o segundo homem mais importante na hierarquia do Terceiro Reich de Adolf Hitler.

${ }^{88}$ Joseph Arnon participou da Bursa e trabalhou no Orfanato nos anos de 1929-1932. Imigrou à Terra de Israel e foi membro do Kibutz Ein Hamifratz.
} 
duzentos mil habitantes judeus na Palestina. A cidade de Tel Aviv possuía quarenta e cinco mil habitantes em 1931. Estes vieram, em sua maioria, com recursos financeiros, ativando a economia urbana do Yishuv [conjunto dos habitantes de uma cidade ou país].

A Organização Sionista se ocupava de comprar novas terras, e a iniciativa privada estimulava a construção e o crescimento das indústrias. Foi construída uma salina às margens do Mar Morto, fábricas de farinha, tijolos, óleos vegetais, sabão, cimento, tecelagens e fiações. Também foram construídas usinas elétricas em Tel Aviv, Haifa e Tiberíades. Na agricultura, as frutas cítricas representavam $43 \%$ das exportações do país com o surgimento de vários novos vilarejos. Em 1925, foi criada a Universidade Hebraica de Jerusalém, no Monte Scopus, com a presença de uma multidão com o discurso de Lord Balfour e a aula inaugural proferida por Albert Einstein (BORGER, 2002, p. 525).

Diante desse desenvolvimento econômico e cultural judaico na Palestina, Korczak passa a considerá-la como um país ideal para uma criança se desenvolver e ser respeitada, conquistando seus direitos e se tornando um adulto saudável e emancipado.

O sonho de Korczak de viver a velhice na Terra de Israel e lá sentir saudades da Polônia demonstra seu conflito pessoal de pertencer à Polônia e ao mesmo tempo a Terra de Israel. Ser judeu num país católico implicava pertencer a um conflito de fronteiras. De acordo com Bauman (1989, p. 60):

\footnotetext{
O judeu conceitual era uma entidade semanticamente sobrecarregada, abrangendo e misturando significados que deveriam ser mantidos em separado, e por essa razão um adversário natural de qualquer força preocupada em traçar fronteiras e mantê-las estanques, seguras.
}

Seguindo esta linha de pensamento, o judeu era visto como o inimigo, arquétipo da clareza e da segurança das linhas divisórias de identidade em consequência de seu distanciamento da ordem definida da Igreja Católica. O judeu foi construindo a identidade com a desaprovação do mundo ocidental e carregou em sua história um conflito de fronteiras. Seguir o caminho dos halutzim e viver na Terra de Israel era construir uma fronteira segura, e sentir saudades da Polônia demonstrava a dificuldade do homem de cortar suas raízes com o país. Leo Pinsker, em 1882, descreveu a situação do judeu do seguinte modo:

"Para os vivos, o judeu é um morto; para os nativos, um estranho errante; para os pobres e explorados, um milionário; para os patriotas um apátrida." (BAUMAN, 1989, p. 62) 
Korczak também teve seu tempo de desenraizado a partir dos anos trinta, quando seu patriotismo estremeceu diante da ascensão descontrolada do antissemitismo, principalmente quando isto afetou o cotidiano do orfanato. Nessa época, Korczak iniciou o dilema de uma dupla diáspora, polonesa e judaica, que para ele não trazia saídas alternativas. A exclusão da pátria significava uma desculturação, segundo Tzvetan Todorov ${ }^{89}$, a degradação da cultura de origem. E a aculturação, a aquisição progressiva de uma nova cultura, capacidade inata dos seres humanos (TODOROV, 1999, p. 24) Entretanto, Korczak não se sentia preparado para o processo de desertar a pátria polonesa. Korczak, assim como Todorov, observou que o desenraizamento da pátria produz sensação de ser um estrangeiro em sua casa (no caso de Korczak, a Polônia) e em casa no estrangeiro (no caso, a Palestina).

\title{
Documento $\mathrm{n}^{\circ} 06$ - Carta de Korczak enviada a para Joseph Arnon em $15 / 05 / 1933$
}

\begin{abstract}
"É suficiente para mim ter conhecido aqui uns dez ou quinze imigrantes da Terra de Israel, para saber como são as pessoas lá: como as pessoas de qualquer lugar. Talvez, por dentro e por fora, sejam um pouco mais amargas um pouco mais ansiosas. As pessoas podem ser intelectualmente divididas em duas categorias: aquelas que se rebelam contra a vida, e aquelas que a aceitam como ela é. Se algum dia eu fosse destinado a ir à Terra de Israel, não iria pelas pessoas de lá, mas simplesmente pelos pensamentos que poderiam me ocorrer ali. O que o Monte Sinai, o Jordão, o Santo Sepulcro, a Universidade Hebraica, os túmulos dos Macabeus, o Mar da Galiléia, e mesmo Purim em Tel-Aviv e as plantações judaicas de laranja significam para mim? Minha experiência, afinal, é de dois mil anos de história na Europa e na Polônia, de judeu errante. E agora que tantos judeus alemães vão para Palestina receio que terei ainda menos de um sentimento das coisas lá [...]. O que o mundo precisa não é de trabalho braçal ou plantações de laranja, mas de uma nova fé, uma fé no futuro e na criança como fonte de toda a esperança." (ARNON, 2005, pp.79-80)
\end{abstract}

Korczak planejou e definiu uma data para conhecer de perto tudo o que lhe era relatado. Em julho de 1934, fez sua primeira visita à Terra de Israel com os planos de ficar no mínimo por três semanas no Kibutz Ein Harod e observar principalmente a vida das crianças. Esse trecho da carta contém algumas informações em que é possível destacar que Korczak

\footnotetext{
${ }^{89}$ Nascido em 1939 é um filósofo e linguista búlgaro radicado na França desde 1963. Dentre várias obras, publicou O Tempo dos Desenraizados, Rio de Janeiro: Record, 1999.
} 
tinha o plano de conhecer a Terra de Israel. De acordo com Moshe Shner (2008) sua vontade de viver em Eretz Israel lhe seria uma oportunidade para imergir no passado, encontrar estímulo para refletir no presente e talvez, vislumbrar uma nova chance de vida para o futuro. E ainda assim sentir saudades da Polônia.

Entendemos por essa missiva que Korczak amava a Polônia a ponto de ressaltar que, mesmo num lugar ideal, ainda suspiraria pela pátria amada. Isto lhe trazia dilemas pessoais, pois como viver em um país e sentir saudades de outro? Como viver em Israel e sentir saudades da Polônia? Se a Polônia é tão boa de se viver por que a vontade de ir para a Terra de Israel? A Polônia era para ele o lugar de sua cidadania.

Ao se referir ao lugar em que pessoa possa ter garantido o direito de sonhar com liberdade e autonomia, livre de preconceitos e discriminações ele possivelmente estava contrastando seu dilema em que vivia na Polônia, preocupado com o conflito da dupla identidade e da dificuldade com a adaptação a uma língua nova no novo país. Para Korczak, o conflito linguístico era o desafio ao aprendizado da língua hebraica. Ele se expressava em polonês, sua língua mãe, e este vínculo lhe era muito forte. Portanto, via que o hebraico poderia ser um empecilho à sua adaptação na Terra de Israel. Era um escritor e dependia da língua para expressar as ideias e tinha receio de não conseguir se comunicar adequadamente com as crianças da Terra de Israel. Gershom Scholem (1897-1982), judeu alemão, que emigrou à Palestina em 1923, retratou em seu livro Walter Bejamin: A História de uma Amizade (2008, pp.150-151), a insegurança de Benjamin (1892-1940) de vir se juntar a ele na Terra de Israel. Nas inúmeras cartas trocadas, Benjamin destaca o desconhecimento da língua hebraica e do judaísmo como barreiras à sua adaptação. Benjamin fora convidado a participar academicamente na criação da disciplina de literatura alemã e francesa na Universidade Hebraica de Jerusalém. Ao mesmo tempo em que Benjamin se entusiasmou com esse projeto, adiou-o constantemente, pois, além de problemas pessoais, sentia-se importante para seu país.

Nessa carta, Korczak pode estar se referindo aos jovens dos movimentos juvenis e integrantes da Bursa cheios de novas ideias e desejos para reconstruir a vida na Terra de Israel. São jovens que possuíam força para enfrentar dificuldades da troca de pátria. Korczak classifica dois tipos de pessoas, aquelas que são resignadas e outras que se rebelam diante das injustiças (SHNER, 2008).

Quando ele cita que só de conhecer dez ou quinze emigrantes ele pode então traçar o perfil dos jovens pioneiros: com grandes ideais, muita ansiedade pelo enfrentamento de uma 
nova realidade e as saudades dentro de si. Porém esta saudade reprimida e nem mesmo compartilhada era um modelo de heroísmo que amputava emoções e sentimentos.

Segundo Tali Shner (2008), a Terra de Israel é vista por Korczak como a terra dos ancestrais, a terra nova e velha. Uma terra em que o homem funde o corpo e o espírito. Uma Terra que exige uma troca de língua, de cultura, de clima e geografia, na construção de uma nova identidade, uma assimilação da língua e cultura novas.

Os pensamentos a que ele se refere são a possibilidade da criação de novas ideias livres da interferência da violência vividas nesta época. Um lugar onde ele pudesse desenvolver uma nova fé, que obrigatoriamente está ligada à criança como fonte de esperança. Uma terra onde ele pudesse desenvolver seu ideal educativo, onde a criança pudesse ser o que ela é com seus sonhos, desejos e suas crenças.

\section{Documento no 07 - Carta de Korczak enviada a Joseph Arnon em 06/12/1933}

Ao menos se tivesse recursos, gostaria de passar meio ano na Terra de Israel, para contemplar o passado, e meio ano na Polônia, para manter as coisas acontecendo por lá [...]. Durante anos tenho observado o desamparo, a tristeza silenciosa das crianças sensíveis, por um lado, as artimanhas descaradas dos animais adultos, por outro. Receio que estejamos apenas testemunhando a destruição, sem sentido, de tudo o que é honesto e amável, o massacre dos cordeiros pelos lobos.

Não tenho ilusões - o mesmo deve acontecer na Terra de Israel. Talvez, dadas as minhas condições não familiares lá, minha falta de contatos, ignorância da língua e distância de todas as pessoas, poderia ser capaz de fazer de mim mesmo uma pequena célula monástica, mas viajar para executar este ou aquele trabalho - não, nunca. É demais comprometer-me deste modo (KORCZAK, 1978, p.180).

Korczak manifesta o desejo de passar seis meses na Terra de Israel para conhecer a realidade de perto e, ao mesmo tempo, manter a ligação com a Polônia. Em várias cartas perceberemos que ele sempre volta com dúvidas pessoais sobre a decisão de conhecer a Terra de Israel.

Ele reflete, questiona, responde, e finalmente, com ajuda de Stefa e também pela influência dos jovens sionistas que trabalhavam no orfanato, tomou uma decisão de fazer a primeira viagem a Terra de Israel. 
Quando Korczak traz a metáfora do animal adulto está fazendo uma referência ao partido nazista que subiu ao poder em 1933, na Alemanha, e sua influência antissemita disseminada na Europa. Korczak traz duas metáforas sobre a criança e o adulto. Na primeira faz referência ao desamparo e a tristeza silenciosa das crianças sensíveis e na segunda sobre as artimanhas do animal adulto. Nessa época em que o antissemitismo fora autenticado e disseminado devido à ascensão de Hitler ao poder na Alemanha a intolerância era praticada com o aval da autoridade nazista. $\mathrm{O}$ animal adulto caracterizou-se pelos indivíduos da sociedade que isentos da moral ética e cívica agiam cruelmente contra àqueles que não se enquadravam ao perfil do homem de sangue puro ditado pelo nazismo, como os judeus, comunistas, ciganos, homossexuais e deficientes físicos mentais. Desde o início do século XX o status social destes foi sendo rebaixado ao ponto de não pertencerem mais à sociedade e não possuírem direitos civis. A concequência da intolerância produzia a tristeza silenciosa das crianças sensíveis como cordeiros massacrados pelos lobos. Essa metáfora nos dá uma dimensão do sofrimento e o sentimento de impotência da criança diante da maldade generalizada e impune praticada em massa na sociedade européia em geral e principalmente na Polônia. De acordo com Korczak as crianças eram as primeiras a sentir a violência dentro da sociedade ao ficarem isoladas e proibidas de sair de casa. A brutalidade das manifestações antissemitas repercutia silenciosamente nos corações infantis que por medo tinham que calar-se. Para exprimir sua angústia cita uma passagem bíblica do profeta Isaías (11-6) comparando as crianças com os cordeiros e os nazistas com os lobos. Porém, a profecia que fazia uma alusão à paz, nesta carta Korczak traz uma realidade oposta.

Para Korczak, enfrentar o desafio de conhecer a Terra de Israel envolvia a dificuldade de comunicação pela ignorância da Língua Hebraica, e falta de proximidade com a tradição e cultura judaica que não fizeram parte de sua formação na infância. Também demonstra que tem uma ligação forte com seu trabalho em Varsóvia e não poderia se comprometer com um trabalho específico na Terra de Israel.

O dilema de Korczak em relação a sua pertinência à condição de cidadão polonês ao mesmo tempo em que se sente um judeu foi compartilhado pelo poeta Julian Tuwim ${ }^{90}$. Ele o demonstrou no seu manifesto chamado "We Polish, Jews..." onde abordou a ligação de um cidadão polonês à sua pátria. E a sua explicação das razões que o levam a se sentir como um polonês e como um judeu simultaneamente.

\footnotetext{
${ }^{90}$ Julian Tuwin (1894-1953), poeta judeu polonês que escreveu em Abril de 1944 o manifesto sobre a destruição dos judeus poloneses chamado: "We, Polish, Jews...". Esse documento foi escrito um ano depois do Levante do Gueto de Varsóvia quando a dimensão da catástrofe sobre os judeus permeava a consciência dos sobreviventes. Tuwin, J., My, Zydzi Polscy, Kwiaty Polskie, Wydawnicwa Artystyczne i Filmove, Warszawa, 1988.
} 
Se, entretanto for explicar minha nacionalidade, ou de preferência meu senso nacional de pertinência, então eu sou polonês, pela mais simples e quase primitiva razão. A maioria racional, e uma parte irracional, mas desprovida de qualquer floreio místico. Ser polonês não é uma honra nem uma glória e nem um privilégio. É como respira. E não conheço nenhum homem que é orgulhoso por respirar.

Sou polonês porque foi na Polônia que nasci e fui criado, que cresci e estudei; porque foi na Polônia que fui feliz e infeliz; porque do exílio é para Polônia que quero voltar, mesmo se me forem prometias alegrias em outro lugar.

Um polonês - porque devido a algum preconceito que sou incapaz de justificar por por nenhuma lógica ou razão, desejo depois de morrer ser absorvido e dissolvido dentro do solo polonês e nenhum outro.

Acima de tudo um Polonês - porque quero ser.

[...] Tudo bem, alguém dirá: Garanto que você é um polonês. Mas neste caso, porque "nós Judeus?" Ao que eu respondo: Por causa do Sangue. Então racismo novamente? Não, não é racismo. Muito pelo contrário. Existem dois tipos de sangue: aquele que vem das veias e aquele que jorra delas. O primeiro é o fluido vital do nosso corpo e como tal, está sob o domínio dos médicos. Quem vai atribuir a este sangue mais qualquer outra característica que não biológica [...]

O outro tipo de sangue é o mesmo sangue, mas que jorra pelo líder do bando do fascismo internacional para testemunhar o triunfo do seu sangue sobre o meu, o sangue de milhões de inocentes assassinados, não de sangue oculto nas artérias, mas revelado para o mundo.

Nós judeus poloneses... Nos, sobreviventes, que perecemos nos guetos e campos, e nós os fantasmas que do outro lado dos mares e oceanos, teremos um dia de voltar à terra natal e assombrar as ruínas em nossos desprezados corpos e as nossas miseráveis almas supostamente poupadas.

Nós, sufocados em câmara de gás e transformados em sabão de sabão que não vai limpar as manchas do nosso sangue, nem o estigma do pecado que o mundo perpetrou sobre nós.

O poeta Tuwim exprimiu em sua poesia a diferença de sangue que pode variar entre pessoas de uma mesma nação. Segundo Tucci Carneiro (2002, p 341), ao longo de quinhentos anos, as sociedades europeias e americanas acreditaram na ideia de que alguns poucos eram representantes de uma mesma raça superior por serem portadores de um sangue especial. Puro sem mácula. Continuando nesse pensamento, a metáfora do sangue utilizada por Tuwim demonstra um pensamento medieval que, sob o ponto de vista do preconceito se prestou como 
elemento de exclusão social. Desse modo, o judeu era considerado uma raça inferior e passível de sofrer preconceito.

\subsection{Registros da Primeira Viagem: 1934}

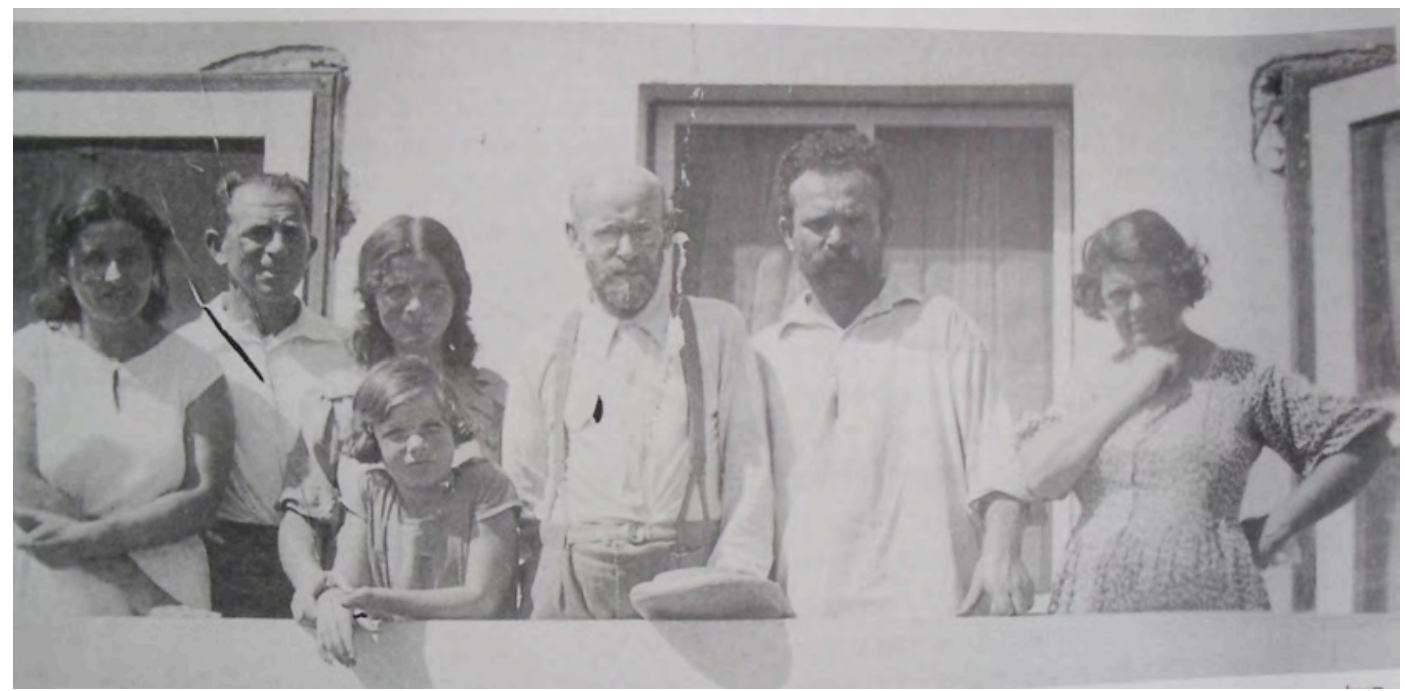

Imagem 27 - Korczak com a família Samhoni à sua esquerda e Gur-Arieh à sua esquerda no kibutz Ein Harod em 1934. Fonte: Beit Lohamei Haguetaot

Korczak decidiu realizar sua primeira viagem à Terra de Israel e, com a ajuda de Wilczinska, programou a viagem com duração de três semanas.

Korczak chegou à Palestina em setembro de 1934 e ficou hospedado no Kibutz Ein Harod na casa da família de David Samhoni, amigos de Stefa quando esta visitou o kibutz em 1931 por 3 meses. Ein Harod foi o primeiro kibutz ${ }^{91}$ fundado na Palestina em 1921 com 215 membros. Em 1934 contava com 330. Vimos até agora que nesta visita Korczak manteve encontros e diálogo com os educadores e com as crianças nascidas na Terra de Israel, e resgatou a ligação espiritual com a terra bíblica. A família de David Samhoni serviu de base para o descobrimento da vida do kibutz: o refeitório, a escola, a sapataria, o cemitério. Samhoni traduzia e intermediava as conversas entre ele e os membros do kibutz. Korczak não entendia o hebraico e a comunicação se deu pela da emoção e sentimento. Ele tinha uma conexão com as crianças que falavam ao coração, dispensando palavras. Samhoni escreveu em suas memórias ${ }^{92}$ :

\footnotetext{
${ }^{91}$ A primeira Kvutzah [pequeno kibutz] Degânia foi fundada em 1909 às margens do lago de Tiberíades por dez homens e duas mulheres.

${ }^{92}$ Korczak chegou a Haifa num navio na sexta-feira, 24 de julho de 1934. Em Samhoni, D. A viagem de Korczak na Terra de Israel, Iediot Beit Lochamei Hagetaot, $\mathrm{n}^{\circ} 1-2,18-19$, abril de 1957, p.66. Samhoni anotou em seu
} 
Ele aproveitou o tempo livre para passear na parte antiga de Haifa até que o ônibus para Ein Harod chegasse ao terminal. E experimentou o doce que vendiam os jovens árabes. O hóspede chegou a Ein Harod antes do anoitecer. Nos primeiros dias de sua estada em Ein Harod temeu aproximar-se das crianças por não falar o mesmo idioma. Uma vez ao dia anotava no seu diário as frases completas em hebraico para estudá-las em outro momento. Ele não aceitou as propostas de passear fora de Ein Harod e preferiu essencialmente conhecer a vida do kibutz em si. Nas noites havia um grande pedagogo discursando para um público de educadores e uma plateia interessada, sobre a criança, sua vida e seus direitos. Essas palestras eram um conhecimento importante na vida de Ein Harod.

Korczak se interessou pelo sistema comunitário de educação do kibutz, visitou a escola e participou das aulas, trabalhou no berçário para evitar confrontar-se com a língua hebraica e se reuniu com a equipe de educadores do kibutz. De noite proferiu várias palestras sobre sua visão e experiência educacional. Interessou-se pela questão da manutenção da instituição agrícola que podia acolher novos membros sem cobrar taxas de adesão. Propôs-se a trabalhar na cozinha e realizar a simples tarefa de "descascar batatas" junto com os imigrantes poloneses e russos facilitando a sua adaptação nos primeiros dias de sua chegada.

diário a data em que Korczak chegou à Palestina, mas Perlis e Sharshevski definem a data como setembro de 1934. E esta última confere com a data da festa de despedida para Korczak em Ein Harod, em 03 de outubro de 1934. 


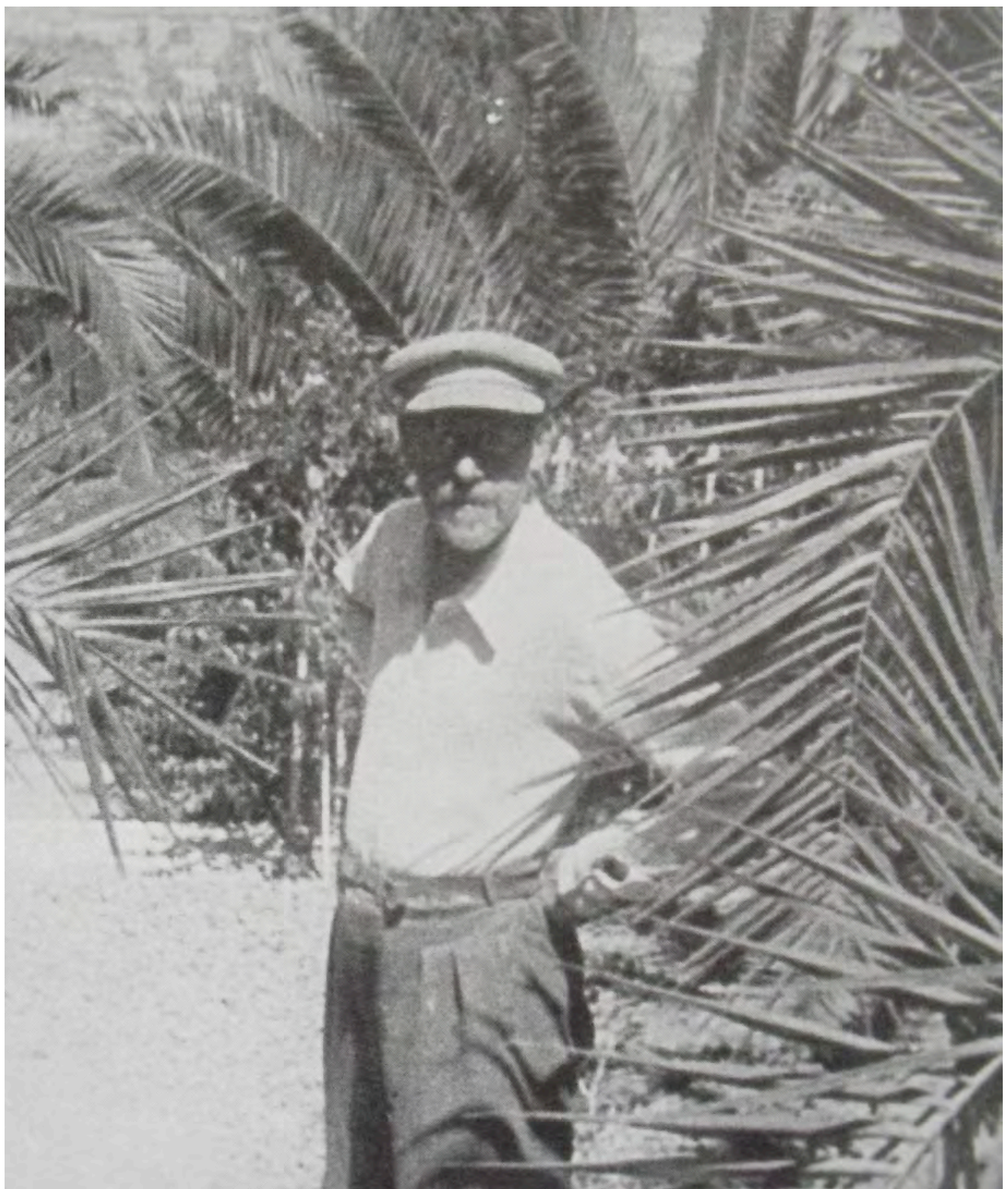

Imagem 28 - Korczak no Kibutz Ein Harod em 1934. Fonte: Beit Lohamei Haghetaot. 


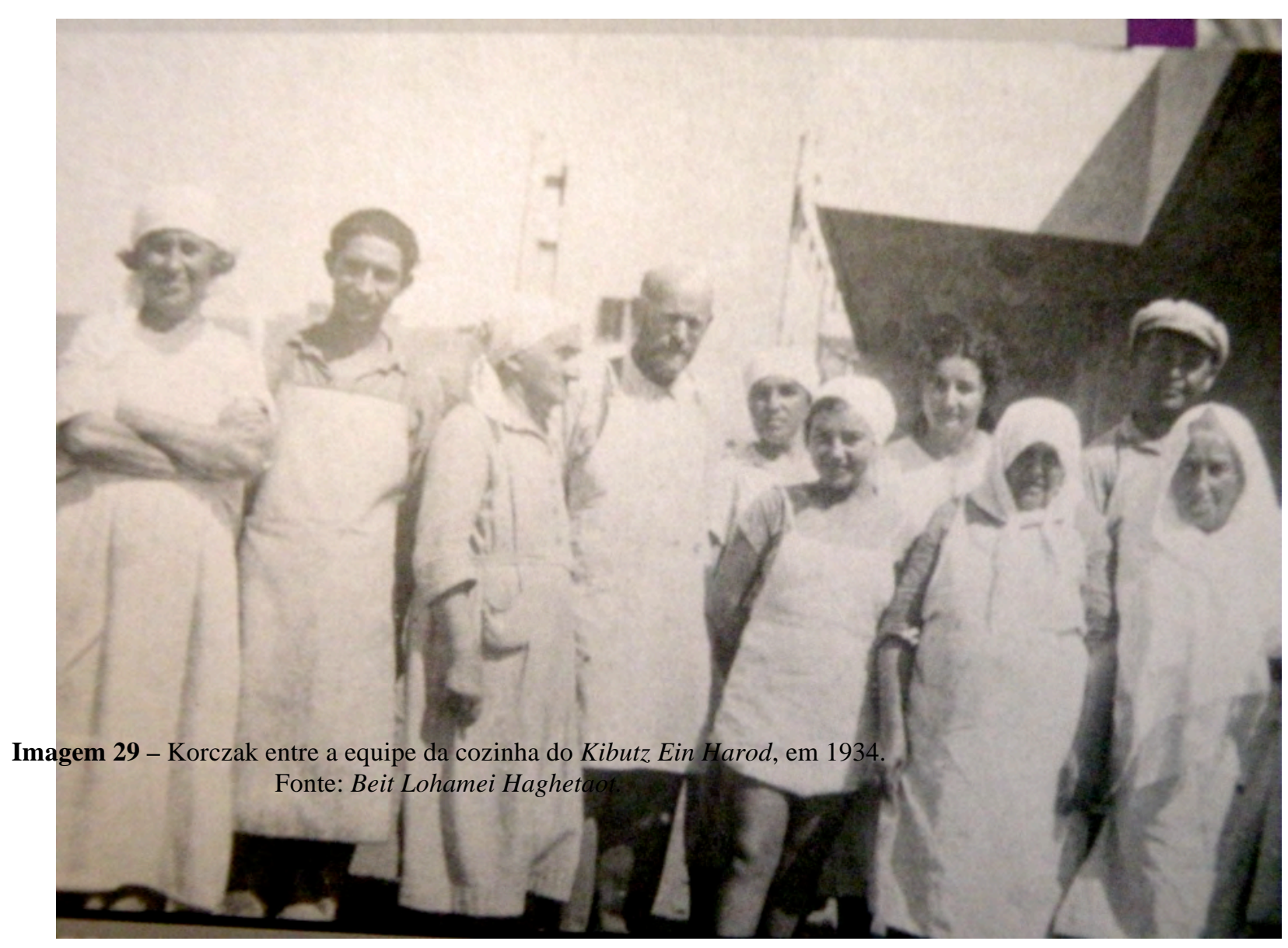

Embora se tenha programado para dedicar o maior tempo ao kibutz, foi conhecer a região do Vale do Jordão, na Galiléia. Em Kfar Guiladi, visitou uma escola Kaduri, do rabino cabalista Isaac Kaduri (1897-2006) e Nazaré. Também viajou para Tiberíades e se encontrou com um velho padre polonês. Procurou entender o desafio deste chefe da igreja católica de viver num lugar como a Palestina diferente da Polônia na geografia, língua e costumes.

A arquivista de Ein Harod Aza Ronen organizou muitos documentos sobre Korczak e Stefa em suas passagens pelo kibutz. Ela era estudante do ensino primário na época e registrou suas memórias sobre o convívio e os sentimentos que as crianças do kibutz manifestaram por Korczak. Por vários anos consecutivos, ela pesquisou e arquivou os registros de Korczak e Stefa relativos à Terra de Israel. Em 1983 participou de um encontro de educadores em Varsóvia, em que definiu a relação com Korczak:

"Éramos ainda muito jovens em Ein Harod, mas sentimo-nos importantes diante da presença e personalidade de Korczak. Mais de uma vez ouvimos as discussões e conversas entre os educadores sobre as ideias transmitidas nas palestras de Korczak que aconteciam em diversas noites do kibutz". 
Sobre os passeios com os alunos às redondezas de Ein Harod como Emek Izrael, à fonte de Ein Harod e Gilboa assim escreveu sobre Korczak:

"Korczak pediu para participar conosco de nossos passeios por esses lugares. No caminho ficava concentrado, atento e emocionado e conversava com nossa professora em polonês. Ele era aguçado nos conhecimentos da Bíblia hebraica". 93 (RONEN apud SHNER, 2008, p.47)

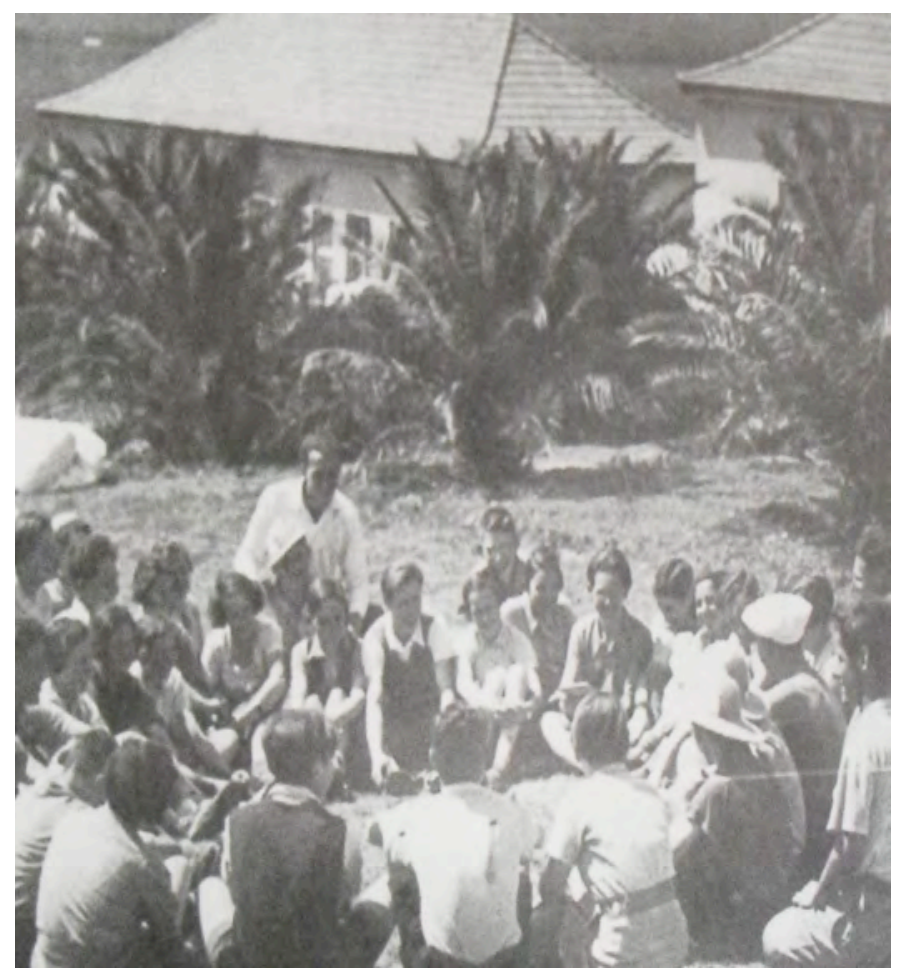

Imagem 30 - Korczak com as crianças de Ein Harod em 1936 Fonte Beit Lohamei Haghetaot.

Em dezembro de 1977, Aza publicou suas considerações sobre as palestras de Korczak proferidas nos kibutzim, em 1934 e 1936 no Igeret Hachinuch [Nota de educação] de Ein Harod. Neste documento ela levantou vários assuntos educacionais discutidos com Korczak e ainda relevantes para os educadores. Os temas variavam entre estes: o sono infantil, o papel da herança genética, alimentação e nutrição, a criança nervosa e difícil de

\footnotetext{
${ }^{93}$ Em A ligação entre Korczak e o Kibutz Ein Harod, palestra no encontro de educadores em Varsóvia, abril 1983. Registro $n^{\circ}$ 4335, Kibutz Ein Harod.
} 
educar, a função do educador, o passivo e o ativo na educação, as descobertas sexuais, os desejos eróticos da criança e os tipos de criança (RONEN apud SHNER, 2008, p.47) ${ }^{94}$.

Desse registro, observamos o conhecimento de Korczak adquirido em sua experiência no campo da medicina, psicologia infantil, educação nos orfanatos, colônias de férias e na corte infantil. Seu pronunciamento sobre a relação do adulto com a criança permeava seus discursos invariavelmente na intenção de proteger e resgatar os direitos infantis. Acima de qualquer conhecimento teórico, Korczak respeitava as emoções próprias da criança e suas sensações distintas do mundo adulto.

Aza Ronen entrevistou Iehuda Gur Arieh, originário da Rússia e membro de Ein Harod, que estabeleceu um contato próximo com Korczak. No relato de Gur Aieh percebe-se o envolvimento de Korczak com a vida dos membros do kibutz e a procura do entendimento das razões que levam os indivíduos a deixarem a terra natal e imigrar para uma nova terra:

[...] Sentou-se ao meu lado e ficou observando meu oficio com martelo e os pregos. Encontrávamo-nos muito a noite, caminhávamos e conversávamos. Ele se interessou muito pela vida no Kibutz e sobre a vida das pessoas. Korczak falou: O homem é obrigado a saber muito para se conhecer, e depois ele fica estarrecido por ver que não sabe tudo. [...]. Contei a ele sobre minha infância difícil, órfão já na barriga da minha mãe. [...] Korczak se sensibilizou muito com a minha história de vida e percebi que seus olhos brilharam. Disse para ele: Eu sou muito grato ao sionismo; se não existisse a Terra de Israel eu teria morrido. E pude perceber seu envolvimento com o sionismo. (RONEN apud SHNER, 2008, p.47)

Gur Arieh relatou que Korczak se impressionou com a comunidade laica do kibutz que respeitava os indivíduos que preservavam os ritos religiosos. Ele contou que Korczak o acompanhou à sinagoga para o ofício religioso de Yom Kipur [Dia do perdão]. Conversaram sobre o significado do sionismo e a solução para os jovens que queriam recomeçar uma nova vida com liberdade.

A admiração dos membros do kibutz por Korczak pode ser observada na declaração de parte do discurso da educadora Liliah Bisvitz proferido na noite de despedida:

Não vou dizer que de agora em diante todos seremos melhores educadores, pais e trabalhadores. Não falarei isto, pois seria um exagero e não acreditariam em nós. Mas cada um de nós sabe consigo mesmo que o mais moderno e renovado caiu em nossas almas e desse momento em diante

\footnotetext{
${ }^{94}$ Em Korczak Visita à Terra de Israel, "Nota de educação", dezembro, 1997, Registro n 2693, arquivo sobre Korczak.
} 
evoluímos na nossa relação com a criança. Por isso é difícil dar uma definição para isso. É evidente que em todo acontecimento importante com a criança vamos sentir com lagrimas nos olhos a consciência do fato e daremos um nome: Korczak. (RONEN apud SHNER, 2008, p.48)

Ressalta-se nesse discurso a admiração pelo caráter inovador dos ensinamentos de Korczak. A educação comunitária do kibutz caracterizava-se pela autonomia e motivação para o diálogo. O modelo autoritário de educação era obsoleto para o sistema do kibutz que integrava as crianças no sistema democrático da organização. As crianças realizavam funções de acordo com a faixa etária, como a limpeza e jardinagem. A relação da educação do kibutz com a pedagogia desenvolvida nos orfanatos de Korczak era de certa forma similar. As crianças do kibutz, assim como as do orfanato, dispunham de poucas horas com as famílias, viviam em comunidade e eram responsáveis pela organização da vida cotidiana. O kibutz recebia levas de grupos de crianças órfãs ou de movimentos juvenis de países diferentes. Para auxiliar na adaptação, cada criança ou jovem recebia pais adotivos e um lar para frequentar nas horas livres. Portanto, os ensinamentos de Korczak eram relevantes para a realidade familiar e educativa vivida pelos membros do kibutz que ao se referirem aos ensinamentos de Korczak declaram como importantes para a alma.

Korczak foi um dos precursores da mudança do tratamento dado à criança. O tratamento rígido dispensado à criança nas escolas e na sociedade em geral foi motivo de questionamento em suas obras literárias. Ele, com suas teorias, enriqueceu o moderno conceito da infância, conjugando a prática educativa no orfanato no intuito de proporcionar a construção da identidade da criança sob condição dos direitos, respeito e confiança das mesmas.

Quando Korczak foi visitar o recém criado Kibutz Ashdot Yakov visitou a escola primária e deparou-se com a carência de materiais pedagógicos para o ensino. Ao retornar à Polônia enviou uma caixa contendo um material básico que pudesse ajudar esse começo da criação escolar do kibutz. Esse evento foi registrado por Shimon Veis, membro do kibutz:

Nossa escola ainda é muito jovem, tem um pequeno número de alunos e pobre em materiais pedagógicos. Os motivos das dificuldades são diversos. Nos últimos dias nosso patrimônio recebeu um presente, e a isto devemos agradecimentos ao nosso amigo Yoskovitsz ${ }^{95}$. Ferramentas muito caras

\footnotetext{
95 Em carta ao kibutz Ashdod Iacov no ano de 1934, registro n ${ }^{\circ} 2905$ (cópia da carta escrita à mão original) Nesta carta enviada por Yoskovicz de Varsóvia ao kibutz ele alerta para a presença de Korczak em Ein Harod e solicita que o convidem para conhecer e transmitir os ensinamentos pedagógicos .
} 
como um microscópio, uma boa lente de aumento de vidro, uma série de cartazes sobre o corpo humano, cartazes de anatomia, mapas geográficos, gerador de madeira ligado à eletricidade. Tudo isso nos foi enviado de presente pelo grande educador e escritor Janusz Korczak. Ele nos enviou também sua foto. [...] Iremos escrever para o escritor e educador Janusz. Korczak e pensaremos em como agradecer a ele pelo presente maravilhoso que nos enviou. (RONEN apud SHNER, 2008, pp. 48-49)

Rivka Tamir, professora do kibutz, representando seus alunos de Ashdot Yaacov, enviou a seguinte carta de agradecimento a Korczak:

\begin{abstract}
Possuíamos apenas a tradução do polonês para o hebraico dos dois primeiros capítulos do maravilhoso livro infantil "O rei Mateuzinho I" escrito por Janusz Korczak. [...] Terminamos a leitura dos dois primeiros capítulos e a história não acabou. Sabíamos que existia uma continuação, mas não havia sido traduzida ainda. Tivemos uma ideia com as crianças que aceitaram de bom grado. Terminamos a história do livro ao nosso modo [...] e esta edição enviamos, com muitas bênçãos, com um emissário para Varsóvia ao escritor e pedagogo Janusz Korczak (RONEN, 1983, apud SHNER, 2008, p.49) ${ }^{96}$.
\end{abstract}

Ao final de sua estada de três semanas, Korczak regressou a Varsóvia, entretanto, deixou um vínculo estreito com vários educadores que conheceu nos kibutzim e moshavim. E deu início a uma série de correspondências que serão apresentadas no desenrolar desta pesquisa.

No mesmo ano de sua volta em 1934, encontrou-se com o representante do Keren Kaiemet Le Israel na Polônia, Nathan Bistritski, que registrou as palavras de Korczak sobre sua ideia da Palestina:

Não me vi diante de um simples intelectual [...] e sim [...] diante de cavaleiro das sombras da agonia. A conversa entre nós foi cautelosa [...] até que fluíram de sua boca pérolas preciosas que estavam contidas há muito tempo, e a questão do tema: como definir o caráter da criança da Terra de Israel, que cresce numa paisagem inóspita, na ausência de árvores e de paisagens? E ele explica: " a paisagem não é algo exterior [...] a paisagem é uma imagem dupla da alma. Ou para ser mais preciso: a alma é a sensação dupla da imagem. [...] E esta é a problemática da falta de paisagem, que cria órfãos por gerações, da construção e da falta de cultivo de árvore e sua

\footnotetext{
${ }^{96}$ Ver Rivka Tamir, lembranças sobre Korczak em Ashdod Yakov, de acordo com o diário n ${ }^{\circ} 23$ do dia 3 de maio de 1935, registro $n^{\circ} 4954$. . Essa cópia foi revelada por Ronen, somente no ano de 1983, após 48 anos de sua escritura.
} 
sombra. - Pois "o homem é uma árvore do campo" 97. (BISTRISKI, 1979 apud SHNER, 2008, p. 5)

As referências de Bistritski denotam o apreço de Korczak pela natureza e sua influência no desenvolvimento saudável da criança. Quando Korczak compara o homem a uma árvore no campo está trazendo uma concepção da Bíblia hebraica de consciência ambiental, citando com base nesta metáfora a união da ecologia com a espiritualidade. A árvore se desenvolve a partir de uma semente pelo processo da germinação até se tornar uma árvore frutífera. O desenvolvimento do homem tanto físico como espiritual é comparado à árvore no sentido de que ambos nascem de uma semente, crescem, amadurecem e têm frutos. As raízes do homem, como as da árvore, não são visíveis aos olhos e constituem a essência de seu ser e a fonte de sua vitalidade. O tronco da árvore, assim como o corpo do homem, é a estrutura visível de seu crescimento físico e espiritual. Os frutos do homem, como os da árvore, representam a semente e a contribuição que cada indivíduo pode oferecer para a continuidade de sua espécie. Na concepção educativa de Korczak, podemos comparar a educação com as árvores, que são cuidadas e cultivadas com respeito e carinho desde a semeadura. E essa é a base para a construção de uma sociedade baseada no respeito e na justiça. Korczak afirma que a paisagem não é apenas algo exterior, e sim uma imagem dupla da alma e que a alma, por sua vez, é a sensação dupla da imagem. A criança necessita de boas imagens para desenvolver sua personalidade saudável. O contato com a natureza é um importante instrumento educativo para o enriquecimento intelectual e emocional da criança e para captar as imagens que servirão de base para o desenvolvimento desses potenciais. A alma, vista como sensação dupla da imagem que Korczak se refere é a capacidade de desenvolver na criança o entendimento não só da imagem como também o que há por trás dela. Por exemplo a beleza de uma árvore e seus benefícios é uma imagem, e como cuidar e preservar a natureza é outra imagem.

O reflorestamento da Palestina era para Korczak uma condição vital para a sobrevivência dos pioneiros no estabelecimento desta terra geograficamente árida e abandonada. A partir de sua primeira visita à Palestina, Korczak despertou para o problema da falta de água nesta região e a dificuldade do Keren Kaiemet Leisrael para realização do projeto agrícola.

Em sua concepção o contato com a natureza exercia uma experiência enriquecedora sob vários aspectos do desenvolvimento da criança. Como exemplo dessa teoria nota-se a

97 "O homem é uma árvore do campo", Devarim-Deuteronômio: XX 19; 21 
importância que deu às colônias de férias de verão ao longo de sua carreira pedagógica. E no ano de 1921 concretizou o sonho de ter um acampamento de verão para as crianças do orfanato. Este fato se realizou por intermédio do dr Eliasberg que recebeu uma doação de onze acres em Goclawek, a dez milhas de Varsóvia. O sítio foi chamado de Little Rose em homenagem à falecida filha do casal de doadores (LIFTON, 2005, p.133). Korczak solicitou o arrendamento de mais um pedaço de terra para a construção de uma pequena fazenda com um celeiro para uma vaca, dois cavalos, uma cabra e galinhas. Como não havia lago ou rio, quando tinha necessidade de nadar, viajavam de trem para outra cidade.

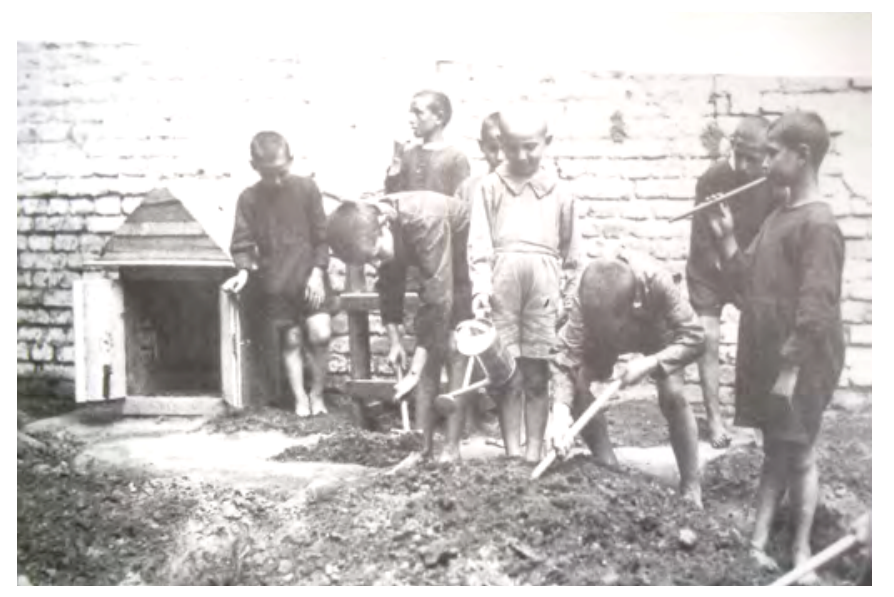

Imagem 31 - As crianças do orfanato no sítio Little Rose na década de 1920. Fonte: Beit Lohamei haghetaot..

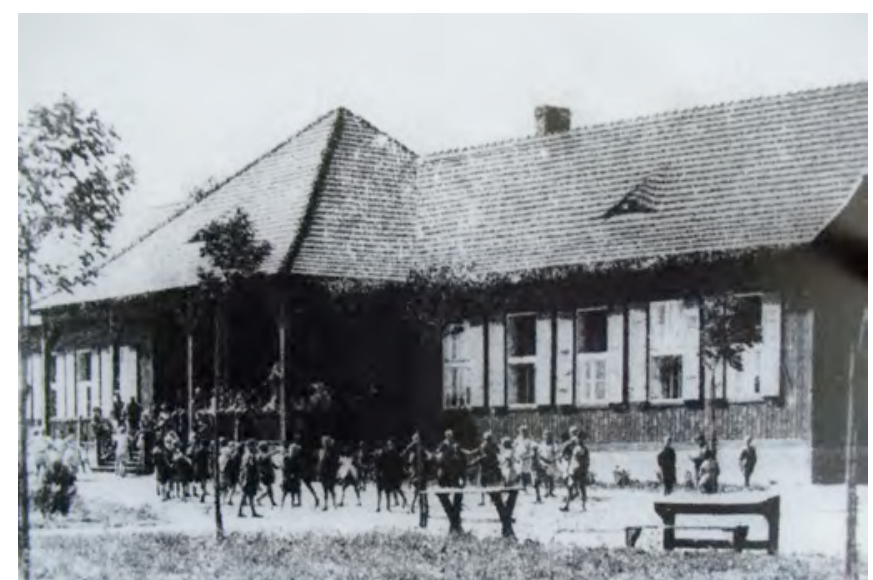

Imagem 32 - O sítio Little Rose na década de 1920. Fonte: Beit Lohamei Haghetaot 
Shimon Agassi (SHNER, 188, p.382n), um dos alunos do orfanato que participou dessa colônia, descreveu essa vivência do seguinte modo:

\begin{abstract}
"A vida no campo era mais relaxante do que na cidade. Depois do café da manhã Korczak pegava pedacinhos de pão com manteiga nas mãos anunciando que eram sorvetes, demonstrando sua maneira espirituosa de estimular o apetite as crianças. Todos os dias havia jogos, esportes e excursões pela floresta para colherem flores e frutos silvestres. Para chamar atenção dos alunos Korczak tocava uma corneta de brinquedo para diversão das crianças, demonstrando que seu amor pela música não correspondia a seu talento musical! Ele era fascinado por formigas e podia ficar horas observando-as e dizia que podia se aprender muito com o trabalho e a organização delas. Durante as noites Korczak levava as crianças para observarem o brilho incandescente das árvores refletidas por minúsculos insetos e plantas. E as crianças podiam perceber que as cores e formas eram fruto da natureza e não fantasmas brilhantes. Durante a estada na colônia a pequena república do orfanato se mantinha com a mesma estrutura e regras e o tribunal continuava funcionando normalmente. A cada criança era atribuída uma tarefa diferente da cidade. As crianças mais novas alimentavam as galinhas e os maiores exerciam tarefas mais difíceis no sítio como todos os cuidados necessários para o cultivo de vegetais e flores e o trato dos animais grandes".
\end{abstract}

A primeira leva de judeus, os biluim $^{98}$, a imigrar a Palestina, chamada de Primeira Aliá por volta da década de 1880, era em sua maioria composta por estudantes russos, e deu início à colonização moderna com o intuito de desenvolver a agricultura como um importante componente do sionismo. O cultivo da terra era a principal ocupação nos primórdios da colonização.

\title{
3.3.1. Impressões de Korczak
}

Os registros de Korczak sobre sua primeira visita à Terra de Israel estão contidos em suas anotações, em artigos de jornal e nos discursos que ele fez para o publico em Varsóvia e nas cartas para os amigos. Durante viagem fez centenas de anotações em vários cadernos, mas a maioria se perdeu na época da Shoah (KORCZAK, 1978, p.135).

Seu artigo em forma de poesia que chamou de A primeira carta foi escrito no navio a caminho de volta à Polônia (KORCZAK, 1978, pp. 69-72):

\footnotetext{
${ }^{98} 15.000$ famílias oriundas principalmente do sul da Rússia.
} 
"Sem descanso olhei para a fumaça, que se elevava da padaria de Ein Harod. Perguntei uma vez após outra a todas as tolas estrelas do infinito do céu e o som em cima do Monte Guilboa [...] Por favor, contem! Olhei para as cruéis pontudas pedras da montanha, o verde do lago Kineret, o olhar das mulas cansadas, e aí irei dizer, eu ouvi o canto dos grilos e o chamado dos galos antes da aurora [...] não tem nada de especial - noite.

Queria em minha primeira carta abençoá-los, agradecer-lhes [...], pedir perdão pela minha falta de confiança [...] viajei com a intenção de discutir o quanto de inverdade há na verdade de vocês. Que através dela determinaram a sua sorte e o futuro de seus netos [...] - mas a verdade revelada é totalmente outra - puros são os esforços e os desejos de vocês, e, as aspirações, preocupações, os embaraços e a bagunça natural. Sim é o "santuário "[...] verdadeira é a sua coragem [...] as sagradas forças naturais humanas não devem ser desvalorizadas.

A linguagem é poética - ele usa várias metáforas para simbolizar os elementos da natureza. Navega pelo universo silencioso, referindo-se ao oceano e à escuridão que cobre a terra e ele tenta ouvir e prestar atenção às vozes que não são ouvidas. A natureza está sempre em pauta nos seus registros. Korczak recorre aos elementos da natureza nas observações sobre a Palestina e descreve a paisagem que observou. A referência sobre a noite em Ein Harod aparece nas memórias descritas como a minha noite. Sobre a carta de agradecimento nota-se a sua preocupação em revelar a falta de confiança que ele tinha no empreendimento sionista e a realidade que ele conheceu, mas sua impressão a respeito da colonização e o trabalho agrícola foi além das expectativas. Antes de conhecer pessoalmente acreditava que o trabalho dos halutzim era movido por um sonho infantil com muita retórica e pouca ação. Ele pode constatar que os jovens estavam dispostos a sacrificar os anseios pessoais em troca do desenvolvimento comunitário. Korczak chega a afirmar que a ação do halutzim tem uma conotação sagrada, como se os próprios jovens estivessem dando continuidade às histórias epopeicas da Bíblia Judaica e tornando-se parte das escrituras sagradas.

De acordo com Shner (2008, p.51), quando chegou à Varsóvia, Korczak foi convidado a relatar sua primeira viagem à Terra de Isael a um público de educadores e intelectuais judeus acostumados a receber palestrantes provenientes da Palestina. Segundo a autora, Korczak pormenoriza alguns aspectos da sua experiência na Palestina. Uma das questões levantadas por ele era desmistificar a imagem do pioneiro e de sua vida cotidiana 
diante da realidade que ele conheceu. E a palestra foi publicada no jornal Nash Psheglond ${ }^{99}$ seguiu por vários tópicos descritos a seguir:

1 - Sobre a coragem dos pioneiros [halutzim], argumentou que havia na ação deles uma dimensão corajosa, contínua e diária. No tema do trabalho braçal judaico ele ressalta sua compaixão pelos pioneiros que secam os pântanos e constroem estradas e ressalta que também os árabes fazem este tipo de trabalho.

2 - Sobre as laranjas, Korczak argumentou que havia exagero, e que a maioria das crianças da Palestina não conhecia as melhores laranjas que eram destinadas à exportação.

3 - Sobre a dança da hoira (dança folclórica), explicou o quanto foi emocionante admirar os pioneiros dançando principalmente no navio que os leva à Palestina.

Não sei e não tenho certeza de que estes que sabem dançar tão bem sabem trabalhar com esse mesmo do. A dança é como a vodka que desperta as pessoas. (Arquivo de Korczak, 1934).

4 - Sobre os jovens pastores que leem Kant nas horas vagas no kibutz, argumentou que descobrem que essa leitura não é suficiente para aprender o pastoreio e que deveriam aprender o segredo de pastorear com os árabes.

5 - Sobre a cidade de Tel Aviv, considerou que se parecia como qualquer bairro novo de Varsóvia, por exemplo, "Zolivoz". E sobre o assunto da escassez de água considerou a necessidade de racionar o consumo no cotidiano.

6 - Sobre a suposta falta de fé dos pioneiros e a permissividade entre as crianças relatou que em Rosh Hashana ${ }^{100}$ observou que alguns jovens frequentavam a sinagoga do kibutz e havia mezuzáa ${ }^{101}$ nos umbrais de algumas casas. E sobre as crianças observou que estas tomavam banho juntas somente até uma idade consensual do sistema educativo de cada kibutz.

7 - Sobre as saudades dos pioneiros de suas famílias, da terra natal, da língua e da cultura, salientou a ocorrência destes fatores na geração recém chegada da Europa. E

\footnotetext{
99 Artigo no jornal Nash Pesheglond, jornal judaico- polonês em 10-12-1934, registro n5253, arquivo de Korczak.

${ }^{100}$ Festa religiosa judaica em comemoração ao ano novo.

${ }^{101}$ Artigo religioso afixado nos umbrais das portas das casas com a finalidade de proteção do lar.
} 
afirmou que a atenuação desse sentimento aconteceria ao longo das gerações nascidas na Terra de Israel.

Além disso, Korczak relatou sua admiração com o elevado nível educacional das escolas fundamentais dentro do kibutz e de sua continuidade ao ensino médio (antigo colegial) fora dos kibutzim que integravam os jovens em uma instituição. Cada kibutz e moshav enviavam suas crianças para uma instituição educacional da região que abrigava os alunos. 


\subsection{Cartas de 1934 a 1936}

As cartas que escreveu aos seus amigos, quando retornou a Varsóvia, continham sua percepção sobre a Terra de Israel e a descrição do trabalho comunitário desenvolvido nos kibutzim. Korczak dedicou-se a escrever sobre o impacto pessoal do seu encontro com a Terra de Israel, o seu profundo relacionamento com as pessoas que encontrou, e sobre o fato da ação sionista ser uma carga demasiada difícil para o jovem pioneiro. Nas cartas a seguir podemos destacar as ideias de Korczak relatadas acima.

\section{Documento $n^{\circ} 08$ - Carta de Korczak enviada para Mia Samhoni ${ }^{102}$ em $5 / 12 / 1934$}

Amada Mia,

Nem seu pai e nem sua mãe me escrevem e não sei como eles estão. Obviamente eles não têm folga, então lhe escreverei. - Portanto escrevo que cheguei a Varsóvia e contei que fiquei muito feliz e satisfeito na Terra de Israel. Só uma coisa não foi boa, o fato de que não pude falar hebraico com você e nem com suas amigas. -Recebi um livro em hebraico do Sr Yakov, pois vou estudar, mas ainda não comecei, porque tenho muito trabalho. Sempre tenho de escrever alguma coisa, ou diversas reuniões, ou estou ensinando e de novo não tenho tempo de estudar sozinho. Agora mesmo abri as fotos da Terra de Israel na minha mesa e fico me lembrando de tudo que aconteceu. [...] Agora é Hanukál ${ }^{103}$ e os jovens fizeram candelabros de madeira. Em cima de cada mesa eles acendem velas. [...] Escreva-me se choveu como deve... (Korczak, 1978, pp. 184-185)

Nesta carta que escreveu à filha jovem do casal Samhoni demonstra o respeito à criança principalmente por se desculpar pela sua dificuldade com a língua hebraica. A falta da comunicação entre Korczak e as crianças foi sua preocupação durante estada em Ein Harod. E para resolver esse impasse decide estudar a língua e informa a sua amiga, entretanto, demonstra a vida ocupada que lhe dá poucas oportunidades para estudar.

O trabalho de Korczak era vasto. Ele dirigia dois orfanatos, era conselheiro da corte juvenil de Varsóvia, escrevia artigos para jornais, participava do comitê dos orfanatos da

\footnotetext{
${ }^{102}$ Filha pequena do casal Samhoni que hospedou Korczak no kibutz Ei Harod.

${ }^{103}$ Hanuká em hebraico significa "dedicação", "inauguração". Festa das luzes pós-bíblica, que dura oito dias, Chanuká celebra a vitória do pequeno exército de judeus contra o domínio selêucida na Palestina em 165 a.C. que haviam profanado o Templo e imposto sua religião helenística aos judeus. Para celebrar a festa acende-se um candelabro de 8 braços, a chanuki'á durante 8 dias. Em Dicionário Judaico, 1991, p.62.
} 
cidade, tinha um programa de rádio semanal e proferia palestras em universidades e movimentos juvenis. Ainda assim, encontra tempo para escrever sua correspondência à Mia, uma garotinha de Ein Harod, e mostra a ela sua ligação com a Palestina pelas fotos que permanecem espalhadas em sua mesa de trabalho.

\section{Documento n ${ }^{\circ} 09$ - Carta de Korczak enviada a David Samhoni em 7/2/1935: \\ [...] O quanto se pode enriquecer em apenas vinte dias curtos em Ein Harod - o quanto se pode estudar aprender, acrescentar - por muitos dias e para eternidade... (Korczak, 1978, p.186)}

Para seus amigos de Ein Harod, Korczak demonstrou em suas palavras a riqueza cultural adquirida no pouco tempo de sua estada. Exaltou que essa jornada pessoal de conhecimento da Terra de Israel foi uma viagem intimista que lhe permitiu entender melhor a ideia sionista. Este impacto sionista fez entender a profundidade da experiência vivida pelos pioneiros e do seu rompimento com as vidas deixadas para trás.

\section{Documento $^{\circ}$ 10: Carta enviada para Zeev Ioskovicz ${ }^{104}$ em 17/2/1935:}

"Minha querida Ein Harod, as primeiras horas da noite, as divertidas horas passadas na cozinha [...] não consegui resumir o que a terra de Israel me deu [...] vocês exigem de si mesmos muito mais que a força que um ser humano possui!" (Korczak, 1978, pp 187-188)

A ligação de Korczak com Ein Harod foi descrita numa forma poética utilizando a metáfora alusiva à personificação do lugar como se fosse uma pessoa amada. Ao chamar Ein Harod de minha querida ele demonstra ter estabelecido uma relação de intimidade com o sistema de vida e com as pessoas desse kibutz. Ele se refere às noites com afetuosidade de um amante que dorme com a amada. E quando descreve os momentos passados na cozinha revela sua personalidade. Korczak, um intelectual, um homem pertencente à "intelligentsia” de Varsóvia, era também um homem desprovido de altivez. No orfanato realizava as atividades cotidianas simples como arrumar camas e limpar banheiro. Acreditava que os trabalhos

\footnotetext{
${ }^{104}$ Zeev Ioscivicz ( 1896-1977), escritor da língua hebraica e iídishe, membro do Kibutz Guesher e co-fundador do Kibutz Ashdot Yaacov.
} 
deveriam ser realizados por todos os membros do orfanato. A cozinha coletiva do kibutz foi um dos momentos de diversão para Korczak que viajou com a intenção de conhecer os pormenores da vida dos halutzim.

Korczak avaliou o trabalho dos halutzim como algo que exigia uma extrema força tanto do ponto de vista emocional quanto físico. Do ponto de vista emocional pelo fato de abdicarem de terra natal e buscarem se adaptar a uma terra desconhecida, geograficamente distinta e em construção. Misturados entre si por anseios diferentes e provenientes de perseguições antissemitas encontravam-se na Palestina alguns por ideal, outros por fuga ou ambos os motivos. A maioria dos halutzim era proveniente das regiões urbanas da Europa Oriental, eram estudantes, trabalhadores temporários ou possuíam profissões liberais. (Borger, 2002, p.455).

De acordo com Elie Wiesel (2003, p.181):

O processo de desenraizamento de uma criança privada de seus parentes, de sua fé, de seu nome e de sua identidade encarna o mito do judeu errante [...]. O refugiado é um ser amputado de tudo que define uma pessoa normal.

Segundo Todorov (1996, p.26):

Para alcançar a transculturação antes é preciso passar pela aculturação; para poder se desligar com sucesso de uma cultura, é preciso começar pelo autodomínio, pelo "falar".

\title{
Documento $^{\circ} 11$ - Carta enviada a Madaz'ya Markusa ${ }^{105}$ em 25/8/1935:
}

\begin{abstract}
"Direi o que me disse o bom Dr Leezovski [...] nos dias da guerra do Japão, quando estava confuso de lembranças e revoltas: o primeiro ano é o mais difícil - até o vento corta o corpo. O segundo ano - mais acostumado abrese mão das fortes tempestades. O terceiro ano - são apenas suaves lembranças. Depois de três anos a pátria do passado abre espaço para a nova pátria. Então fica-se com a pátria da memória e a nova pátria.. (KORCZAK, 1978 apud SHNER, 2008, p.22)
\end{abstract}

Korczak, recém formado, foi recrutado como médico do Exército Imperial Russo e partiu para o front da Guerra russo japonesa em março de 1905. A Rússia, através da sua

\footnotetext{
${ }^{105}$ Redatora do Jornal "Mali Pleshglond", em 1934 imigrou para Terra de Israel e tornou-se membro do Kibutz Guivat Hayim. Era secretária do "Mali Pshegolond”de 1928 até 1934.
} 
expansão territorial, deu início à construção da ferrovia transiberiana com intenções de chegar ao Extremo Oriente e aumentar seu domínio. O Japão enfrentou o exército russo e entre 1904 e 1905 derrotou-o, demonstrando a fraqueza do czarismo. O Tenente Korczak serviu como médico em um trem hospital na ferrovia transiberiana e encontrava tempo para escrever artigos envia-los para a revista Glos $^{106}$. Esses textos com temas sobre a sua infância e a criança em geral eram publicados em sua coluna chamada "Criança da Sala de Desenho" assinada por Korczak desde a faculdade. Esta época foi o início de seu reconhecimento público como escritor e foi aclamado como a nova voz da literatura polonesa. (LIFTON, 2005, p.43)

Nessa carta em resposta à jovem amiga, Korczak se refere à sua experiência militar para levar consolo provavelmente aos sentimentos saudosistas vividos pelos jovens halutzim. Nesse sentido, pela comparação entre esses sentimentos e os elementos da natureza, pretendia auxiliar sua amiga na adaptação à nova terra.

A carta contém a informação sobre o halutz [pioneiro] que chegava à nova terra, cheio de expectativas, mesmo conhecendo as dificuldades que iria encontrar. Essa experiência de ficar longe da pátria, Korczak havia sentido quando participou na Guerra Russo- Japonesa.

De acordo com Moshe Shner (2008, p. 23), a imigração para a Terra de Israel é um ato total não é só uma concretização de uma ideia, pois o pioneiro tem de se envolver com toda a força física e espiritual. Diante da consciência da complexidade desse desafio que os jovens colonizadores têm que enfrentar, Korczak utiliza-se de uma interessante metáfora:

Quanto tempo leva esta "gestação"? Quando o judeu da diaspóra se transforma num cidadão patriota da pátria antiga nova? A meu ver parece que são três anos.

No primeiro ano a situação de ser arrancado da terra natal, como se fosse um desconhecido, um estrangeiro. O segundo ano é um sentimento de querer desistir de tudo, da ideia, e possuir conflitos alternados de insistir no ideal ou abandonar tudo. Mesmo desmotivado, no terceiro ano há um crescimento silencioso da sensação de que a terra é sua. Ao mesmo tempo o trabalho, o céu, a respiração e o suor irritam e geram uma impaciência. A pele fica ressecada no habitante do norte de Israel.

Plantei três árvores no jardim [...] e essas árvores só se desenvolveram no terceiro ano desde seu plantio. (KORCZAK, 1978, pp. 92-93)

\footnotetext{
${ }^{106}$ Revista escrita pelos intelectuais de Varsóvia, estudantes ou professores da Flying University, instituição de educação clandestina na luta pela liberdade da Polônia.
} 
Moshe Shner afirma que o uso da metáfora da gestação e da árvore é um meio utilizado por Korczak para demonstra que na natureza existe um processo de adaptação próprio no qual se exige tempo e paciência, ele traz aspectos físicos e emocionais importantes que acontecem para o ajuste da mudança. Parte da dificuldade da boa absorção vem da tentativa de ignorar as dificuldades emocionais e desvalorizar a legitimidade dos sentimentos (SHNER, 2008, p. 23). Desse modo, para criar um novo perfil de personalidade do halutz [pioneiro], ou se tornar um tzabar $[\text { Sabra }]^{107}$ era preciso iniciar um processo de esforço pessoal em se adotar um nova personalidade.

A gestação é um processo doloroso em que a mulher enfrenta transformações físicas e emocionais ao longo dos nove meses. Mas desde o principio ela sabe que a experiência será gratificante e quase se esquecerá dos sofrimentos por que passou. A árvore, ao ser plantada, passa por um longo período de transformações para chegar a um tamanho adulto. Depende das condições climáticas e do solo para desenvolver as raízes e desenvolver um tronco forte. As raízes das árvores podem ser comparadas as raízes do homem. E essas raízes tornam-se maiores e mais profundas na terra. Ao arrancar uma árvore de um lugar e transportar a outro dificilmente o resultado será positivo, mas não impossível. Quando Korczak se refere ao período longo de aculturação na nova terra, remete à percepção de que as boas condições emocionais desenvolvidas no período da adaptação são definitivas para que este processo seja realizado.

\section{Documento n $^{\circ} 12$ - Carta enviada a Joseph Arnon em 7/2/1936}

Caro Jusek,

Quando somos tomados por um sentimento de torpor, quando vemos a nós mesmos como supérfluos e desnecessários, quando vemos toda nossa vida como inútil e desprovida de valor, quando sentimos vontade de nos esconder em um canto secreto para refletir pela última vez sobre uma coisa ou outra coisa, a respeito de nós mesmos, sozinhos, ou sem essa introspecção em cessar de existir [...].

Todo homem deseja contribuir com alguma coisa!

Você escreve que todas as minhas dúvidas sobre ter falhado provaram ser falsas. Minha falha consiste no fato de que tudo que me alegrava no passado se tornou um trabalho extenuante, tudo que parecia ser admirável e factível,

\footnotetext{
${ }^{107}$ Termo em hebraico que designa uma fruta originária de Israel, que nasce dos cactos, espinhosa por fora e doce por dentro. Usada para se referir aos pioneiros que habitavam em Israel nos primórdios de seu estabelecimento.
} 
tornou-se agora dúvida, apreensão e vergonha. O progresso atual é tão pequeno e também parece sem importância.

Fiz uma promessa de preservar a criança e defender seus direitos, mas tudo o que posso fazer é uma prece ou uma bênção desejosa de apoiá-la em seus passos apressados e inseguros.

E onde existe um lugar mais apropriado para repreender os indolentes, para guiar os fortes, e defender (em palavras?) os pequenos e fracos - se não em Eretz Israel [Terra de Israel]?

É por isto que anseio.

Mas aqui, para meu desgosto, estou preso (e sobrecarregado) pelo trabalho real (?) que está a ponto de cair.

Se eu pudesse, ao menos, convencer-me de acreditar nisto, a Terra de Israel não admitirá (e de modo algum pode admiti-lo). É por isto que estou autorizado a lá permanecer apenas sob uma condição: não me tornar um fardo para o país.

Todas as vozes que me chegam de lá têm enorme importância para mim, e é por isto que lhe agradeço sinceramente sua carta.

Um abraço apertado,

Korczak (ARNON, apud SHNER, 2005, p. 190)

$\mathrm{Na}$ véspera de sua segunda viagem à Terra de Israel, Korczak demonstra descrença na Polônia, sentindo-se inútil e desprovido de valor a ponto de pensar em suicídio. Nessa carta é possível perceber sua alteração de humor, passando do desespero ao otimismo e a influência carinhosa de seus amigos fieis que o ajudam todo tempo, como Stefa e Newerly, que estiveram presentes em grande parte de sua vida.

Na missiva, ele pondera e apresenta suas dúvidas sobre ir ou não à Terra de Israel, pois ainda quer dar sua contribuição para a Polônia e, ao mesmo tempo, dúvida da validade de sua conduta e do fato de seu ideal ser realmente proveitoso para as crianças. Segundo ele, só lhe restava ter fé e rezar como se esperasse apenas um milagre para reverter a situação das crianças na Polônia.

Por outro lado, em 1922, Korczak publica sua obra A sós com Deus: Orações que não oram (2007) que revela sua ligação com Deus. Segundo Szpiczkowski (2010), há mais 
uma oração descoberta e copiada por Maryna Falska ${ }^{108}$ de um manuscrito de Korczak chamada a Oração do Educador (SZPICZKOWSKI, 2010, p.147), escrita em 7/4/1920, em que Korczak clama a Deus pela sorte das crianças, demonstrando que o apoio de Deus era necessário para a concretização desse pedido. Destacamos um fragmento desta oração:

\begin{abstract}
Meus pensamentos não têm asas que possam levar meus versos para o céu. [...] Apesar de tudo, tenho em minhas mãos uma pedra preciosa que não quero dar a теи irmão - o ser humano. Temo que o Homem não vá entender, não vá perceber, menosprezará e zombará. Como se eu fosse pó para Teus Pés, meu Senhor, eu apresento perante Ti minha ardente reivindicação. Se normalmente me expresso de forma discreta, murmurando, neste pedido declaro com uma determinação contundente, mirando com um olhar determinante por sobre as nuvens. Exijo veementemente, porque desta vez não é por mim. Melhore a sorte das crianças, auxilie-as nos seus esforços e acompanhe com bênçãos suas dificuldades. ${ }^{109}$
\end{abstract}

Esta carta contém a reflexão de Korczak sobre os acontecimentos ocorridos entre sua primeira e segunda viagem à Palestina. A situação política polonesa havia sofrido alterações importantes neste período, que causaram a deterioração das relações dos judeus com a sociedade polonesa. Em setembro de 1934, o governo polonês anulou o tratado com as minorias (os judeus constituíam a segunda maior minoria da Polônia, depois dos ucranianos), no qual eram garantidos direitos iguais e uma onda de insegurança invadiu as várias comunidades étnicas polonesas. Entretanto, o Marechal Joseph Pilsudski, que oficialmente era somente Ministro da Guerra e Inspetor Geral das Forças Armadas, dirigia extra-oficialmente o país, protegendo as minorias, pois nunca havia abandonado a visão da Polônia como sendo uma federação multinacional. Quando, em maio de 1935, Pilsudski morreu, um grande número de judeus ficaram desolados e acompanharam seu funeral temendo pelo futuro da comunidade judaica. Muitos rabinos e centenas de delegações judaicas provenientes de toda a parte da Polônia acompanharam o funeral (LIFTON, 2005, p.214).

Korczak, assim como a maioria dos poloneses, tinha muita esperança na liderança do Marechal Pilsudski para a fortificação da nação polonesa. Sua morte foi um fator de instabilidade social e Korczak fez um pronunciamento em homenagem ao Marechal pela rádio em que trabalhava (LIFTON, 2005, p. 214). Pela nova lei que entrava em vigor, o governo destituía o parlamento democrático, o que provocou o agravamento da situação, com

\footnotetext{
${ }^{108}$ Maryna Falska (1877-1944), educadora e diretora do orfanato polonês Nasz Dom para as crianças da classe trabalhadora de Varsóvia, em conjunto com Korczak.

109 Tradução de Ana Szpiczkowiski.
} 
o surgimento de várias manifestações e greve contra o governo. Esse contexto conturbado e a oposição direitista favoreceram o crescimento do antissemitismo.

A situação da Europa seguia num ritmo progressivo de antissemitismo e, segundo Cytrynowicz (1990), em setembro de 1935, sob a liderança de Adolf Hitler, o governo nazista promulgou a "Lei para a Defesa do Sangue e da Honra", as Leis de Nuremberg. Essas leis proibiam casamentos e relações extraconjugais entre judeus e alemães não-judeus ("arianos”) sob ameaça de severas penas inclusive a de morte. Na Alemanha, a partir da ascensão ao poder do partido nazista em 1933, iniciou-se o processo da crença ideológica na superioridade da "raça ariana" em relação aos outros povos considerados inferiores.

Com a ascensão de Hitler ao poder foram extintos os partidos políticos e a democracia, e foi construído em Dachau um campo de concentração para prender aqueles que eram suspeitos de serem opositores políticos. Livros de autores judeus considerados comunistas, entre os quais Freud, Marx e Einstein ${ }^{110}$, foram queimados em praça públicasem que houvesse quaisquer protestos das 23 universidades e 11 academias de ciências alemãs. Entre os anos de 1933 a 1939, o processo antissemita foi se alastrando da Alemanha para a Europa Oriental, à medida que a Alemanha anexava países e territórios. A política oficial do nazismo - com criação de leis discriminatórias - tinha como objetivo a exclusão radical dos judeus na vida econômica, social e cultural alemã e forçar sua expulsão do país. Essa política foi alterada a partir de 1941, com a construção dos seis campos de extermínio na Polônia, fato que concretizou o plano nazista para a execução do genocídio dos judeus da Europa.

Voltando à Polônia na época entre a primeira e a segunda viagem de Korczak, a situação política polonesa sofreu alterações importantes. Em setembro de 1934, o governo anulou o tratado com as minorias no qual eram garantidos direitos iguais na sociedade e uma onda de insegurança invadiu as várias comunidades étnicas polonesas. Enquanto Joseph Pilsudski oficialmente era apenas o Ministro da Guerra e Inspetor Geral das Forças Armadas extra-oficialmente dirigia o país, as minorias se sentiam protegidas. O Marechal tomou uma atitude repressiva e desiludida com a atitude polonesa em direção à democracia nos seus últimos anos, especialmente contra seus inimigos políticos após o assassinato do Ministro do

\footnotetext{
${ }^{110}$ Korczak assim como Freud (1856-1939) e Einsten (1878-1955) eram ligados à comunidade judaica mesmo tendo sido educados distantes da religião na infância, diferentemente de Marx (1818-1883) que se afastou do judaísmo. Freud escreveu uma carta de agradecimento para a organização beneficente judaica Bnei Brit em 1926, da qual era membro desde 1895, afirmando sua satisfação por ser acolhido em tal entidade (Freud, Pensador da Cultura, Brasiliense, $4^{\circ}$ edição, 1986, p.60). E Einstein apoiava a idéia dos assentamentos judaicos na Palestina e especialmente a Universidade Hebraica de Jerusalém (Eisntein: sua vida, seu universo, 2007, p. 313).
} 
Interior. Mas ele nunca abandonou sua visão da Polônia como uma federação multinacional. Com base nestes fatos Korczak, inspirado pela fé, pelo ideal dos pioneiros da Terra de Israel e com a força do exemplo deles para construir um mundo e um futuro melhores, embarcou no navio "Polônia", em 15 de julho de 1936, e chegou ao porto de Haifa, em 20 de julho, permanecendo na Palestina por seis semanas ${ }^{111}$.

\subsection{Registros da segunda viagem $\mathbf{- 1 9 3 6}$}

Ao aproximar-se da data da segunda viagem para Palestina escreveu um carta assim:

\section{Documento $\mathrm{n}^{\circ} 13$ - Carta de Korczak enviada a Joseph Lichtenboim ${ }^{112}$ em 26/6/1936}

Há uma hora eu recebi meu passaporte. Posso lhe avisar que decidi viajar no segundo navio que parte em julho [...], decididamente irei. Ainda não sei o que farei na Terra de Israel. Após ter conhecido os pioneiros, gostaria de observar a vida dos hashomrim (os guardiões), este é um assunto.. Interessa-me muito a administração individual (moshav) ${ }^{113} e$ a vida dos ortodoxos, [...] se eu puder passarei um mês em Nazaré e um mês em Jerusalém [...] Conforme você percebe é um programa precioso para seis semanas no mínimo e até dois meses e meio no máximo. (KORCZAK, 1978, pp. (192-193)

Nessa carta, Korczak demonstra a indecisão pela qual passou antes de tomar a resolução de viajar. Entretanto, passado esse conflito pessoal revela-se sua vontade de conhecer melhor a vida na Terra de Israel e completar os aspectos não vistos em sua primeira visita.

Korczak manifesta desejo de conhecer os hashomrim [os guardiões], que eram os grupos divididos em ideais políticos diferentes para construção da Palestina. Os halutzim se

\footnotetext{
${ }^{111}$ De acordo com o "Diário", no boletim do Kibutz Ein Harod, do dia 22 de julho de 1936 que continha o registro a seguir: "Está hospedado conosco Korczak da Polônia. Chegou antes de ontem à noite e permanecerá na Palestina por dois meses". Tali Shner, As visitas de Janusz Korczak na Terra de Israel nos anos de 1934-1936, p.53 in Dor Ledor, Studies in History of Jewish Education, In Israel and the Diaspora, XXXIII; Interdisciplinary Studies of the Legacy of Janusz Korczak, Tel Aviv University, 2008.

${ }^{112}$ Joseph Lichtenboim (1895-1968) poeta, ensaísta e tradutor. Amigo de Korczak em Varsóvia e foi o tradutor do polonês ao hebraico do livro infantil de Korczak: O Rei Mateusinho I.

${ }^{113}$ Assentamento ou vila é um tipo de comunidade rural cooperativa que combina fazendas geridas privadamente e cultivação de serviços, como a comercialização de produtos e, algumas vezes, indústria leve. Semelhante ao Kibutz, esta modalidade de assentamento foi introduzida pelo sionismo trabalhista durante a onda de imigração judaica à Palestina no inicio do séc. XX.
} 
identificavam com o Kibutz Hameuchad e os hashomrim, com o Kibutz Haartzi. De acordo com Arie Or, ${ }^{114}$ os integrantes da linha do Haartzi eram os que tinham como ideologia considerar a "mãe Rússia” como a mãe de todas as nações e o comunismo internacional como um movimento ativo central da vida em que cada membro do partido deveria dar sua contribuição à revolução. Por outro lado, os integrantes do Hameuchad não eram extremistas e eram contra o contato direto com a Rússia, mas sua orientação ideológica era socialista. Or conta que dentro de alguns kibutzim havia integrantes desses dois partidos que não se Imagem 33 - Página das anotaçôes de Korczak sobre sua viagem à Terra de Israel em 1936

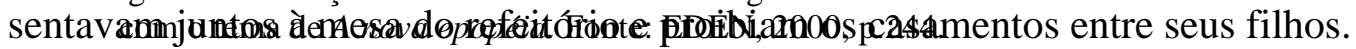

Korczak demonstra seu perfil universalista ao escrever a seu amigo expressando o desejo de conhecer a vida dos judeus ortodoxos e os cristãos da Palestina. Notamos nele uma disposição de observar e aprender o modo de vida e manifestações da fé em diferentes estilos. Ao escrever sobre as viagens à Terra de Israel no texto Eretz Haticvah [A Terra da esperança] (KORCZAK 1978, p. 82) referia-se aos pioneiros e ao empreendimento sionista como a Nova Epopeia, sugerindo que esta obra poderia completar a trilogia dos livros sagrados: Bíblia Hebraica e Novo Testamento e a Nova Epopeia (ÉDEN, 2000, p. 83).

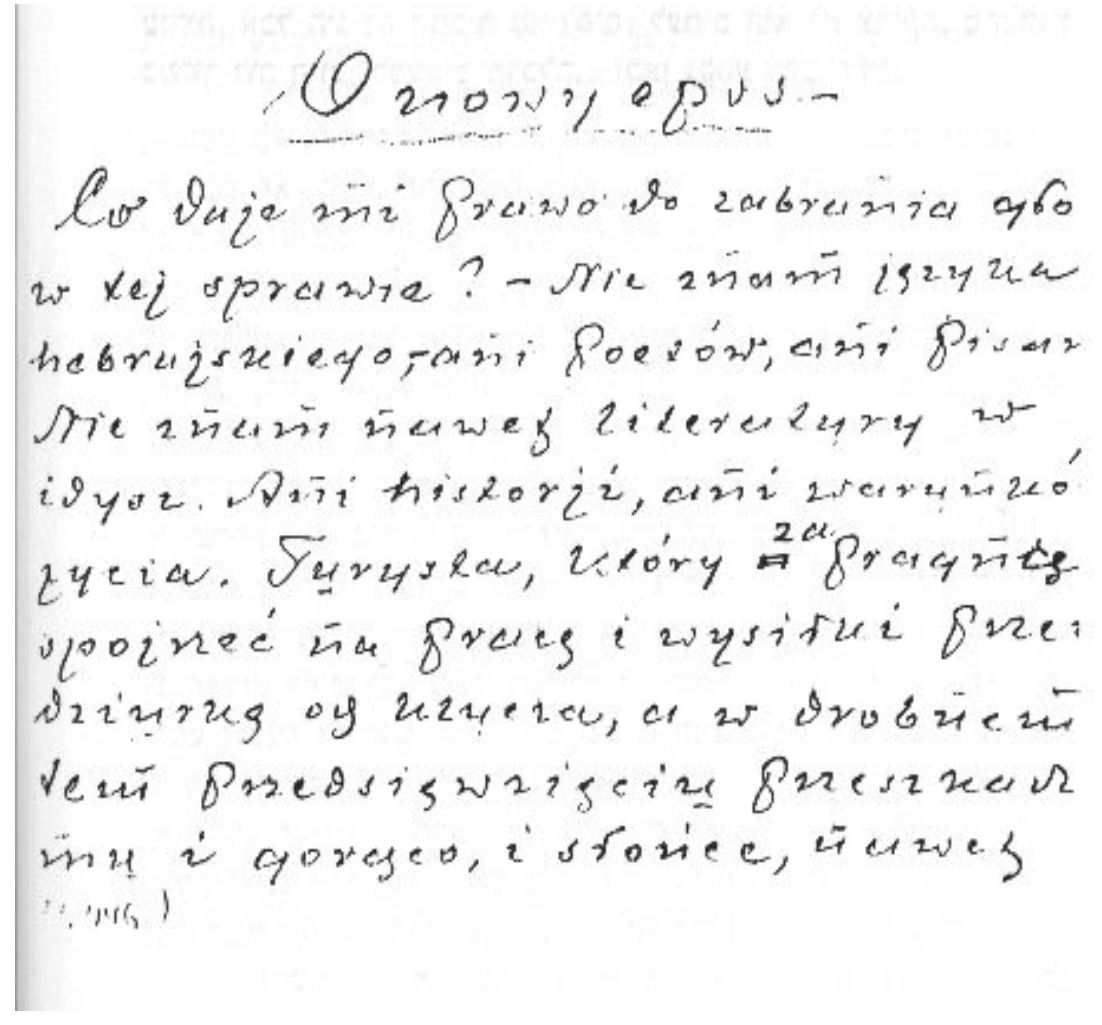

\footnotetext{
${ }^{114}$ Entrevista realizada em 11/05/2011 com Arie Or, brasileiro, nascido em 1961, imigrou para Israel em 1969 para o kibutz Gadot.
} 
De acordo com Shevakh Éden (2000, pp.81-82), Korczak foi educado durante a infância nos princípios da religião católica. Estudou em escolas cristãs e participou regulamente com seu pai das representações natalinas, acompanhando sua governanta às missas dominicais da Igreja. No início da carreira de escritor esses conhecimentos apareceram nos textos, como o faria um escritor polonês dirigindo-se a um púbico polonês. A maioria de seus personagens era constituída por heróis poloneses e os símbolos católicos estavam inseridos naturalmente no enredo. Korczak escrevia sobre as pregações de Cristo que foram publicadas em revistas religiosas. Nesse sentido, o aprendizado do judaísmo com o conhecimento católico intrínseco lhe possibilitou fazer uma análise associativa destas duas religiões expressas em seus textos.

$\mathrm{Na}$ carta que escreveu aos seus alunos que emigraram à Terra de Israel demonstrou sua pluralidade religiosa do seguinte modo:

\section{Documento $n^{\circ} 14$ - Carta de Korczak enviada aos seus alunos na Terra de Israel em 26/8/1936}

Vocês são jovens, vai dar tudo certo. A Terra é grande, sábia e bonita. Vale a pena sofrer e obrigatoriamente se esforçar por isso. Aqui temos as verdades de Moisés e os conhecimentos de Jesus.

(KORCZAK, 1978, p. 435)

$\mathrm{Na}$ viagem de navio em direção a Palestina Korczak conheceu o médico oficial da embarcação, Dr. Alecsander Parver. Eis o registro deste encontro: ${ }^{115}$ :

“Já na hora do embarque, ele (Korczak) estava emocionado.

Sobre o mar juntaram-se nuvens que encobriram o horizonte, e sobre elas claramente brilhavam as estrelas. Durante uma hora ficamos parados assim no navio: admirando ora o mar, ora as estrelas. Dr. Korczak me contou estranhos e diferentes assuntos sobre as pessoas, acontecimentos e fatos experimentados por ele. Ele terminou sua fala sensata e restou uma

\footnotetext{
${ }^{115}$ De acordo com o levantamento histórico de Tali Shner, o Dr Parver terminou os estudos em medicina na universidade de Varsóvia no ano de 1930. Trabalhou no hospital como médico cirurgião, até que se candidatou ao cargo de médico na companhia marítima "Gedinia -América". Ele foi aceito em 1935 e, conforme seu pedido, trabalhou no navio chamado "Polônia" na linha Konstanza - Palestina. No embarque do navio encontrou com Dr Korczak em seu caminho para a Terra de Israel. O registro desse encontro foi enviado pela família Parver para o arquivo de Korczak no ano de 1979 e foi traduzido do polonês por Hovka Avni. A família publicou em 1933, em Jerusalém (em inglês) pela primeira vez em memória ao "Dr Aleksander. Parver" no Edital da Associação Korczak n²3, 1993. In: Shner, Tali. As visitas de Janusz Korczak na Terra de Israel nos anos de 1934-1936, p.53-54; Dor Ledor, "Studies in History of Jewish Education", In Israel and the Diaspora, XXXIII; Interdisciplinary Studies of the Legacy of Janusz Korczak, Tel Aviv: Tel Aviv University, 2008.
} 
sensação da imensidão do infinito do mar e do céu [...] espalham-se as suas histórias como um raio. Já é a terceira noite que nos encontramos e eu presto atenção e o escuto como se estivesse lendo o livro de sua vida.

Segundo Shner (2008, p.54), em sua segunda estada, Korczak permaneceu na Palestina por seis semanas, diferentemente do plano inicial de permanecer por dois meses e meio. Em Ein Harod ficou novamente hospedado com a família Samhoni, fortalecendo a amizade iniciada em 1934. Nessa nova oportunidade, continuou observação atenta sobre a vida das crianças no kibutz e sobre a realidade da educação comunitária e seus problemas. Mas desta vez decidiu sair de Ein Harod para conhecer outras cidades, moshavim e kibutzim (SAMHONI, 1957 apud SHNER, 2008, p.54). Ele foi conhecer as cidades, de Guenigar, Yagur, Beer Tuvia, Guivat Brener, Naan, Merchavia, Kfar Guiladi, Gueva e Kineret. Foi para Haifa no Santuário Baha’i. E para Tiberíades, onde encontrou os monges católicos, e para Jerusalém. (PERLIS, 1986, pp. 128-131)

Korczak se interessou pelo clima e pela natureza da Terra de Israel, pela atividade econômica, pela agricultura, pela questão da segurança e por seus nativos.

Nas anotações desta viagem publicadas no livro Dat Hayeled (1978, p.85) destacou os seguintes itens:

- o problema da escassez de água na região

- a programação diária dos membros do kibutz

- o avanço econômico das colônias

- a natureza: paisagem, as pedras, as estrelas e até mesmo os ventos sobre o monte Guilboa.

- a questão da relação com os árabes.

Pouco tempo antes da segunda visita de Korczak, ocorreu a revolta árabe (1936) em protesto contra a imigração judaica em massa para a Palestina (SHARSHEVSKI, 1990 apud SHNER, 2008, p.54). Desde 1935 já ocorriam tumultos árabes e, poucos dias antes da chegada de Korczak a Ein Harod, o kibutz havia sofrido ataques de bandos árabes em seus pomares. Korczak encontrou o kibutz protegido por soldados e ofereceu-se para a guarda noturna alegando experiência militar (LIFTON, 2005, p.219). 
Os habitantes árabes da Palestina estavam confiantes devido às conquistas dos árabes em outros países como o Iraque e o Egito, que haviam conquistado a independência e que garantiam cada vez mais a autonomia perante o domínio britânico e foram oficialmente admitidos na Liga das Nações. A revolta dos árabes palestinenses contou com a ajuda de outros países árabes e foi incitada pela rádio-propaganda de agentes fascistas e nazistas, dos quais o mufti de Jerusalém ${ }^{116}$ se tornou íntimo colaborador (BORGER, 2002, v.2, p.564).

Sob o comando de David Ben-Gurion ${ }^{117}$ foi proibida uma política de retaliação por razões éticas e políticas e durante dois anos a grande maioria do Yishuv ${ }^{118}$ revelou uma admirável disciplina. Só depois de 1938, a Haganah recebeu permissão para represálias, porém controladas e seletivas. Esta contenção foi de certa forma recompensada pela administração inglesa. As Forças de Segurança Britânicas não reconheciam a Haganá oficialmente, mas passaram a colaborar com ela e estabeleceram uma Polícia Judaica das Colônias (Jewish Settelment Police), com unidades sediadas nas localidades mais expostas e na maioria dos subúrbios urbanos.

Rivka Livne, ${ }^{119}$ membro do kibutz Gueva, professora que Korczak conheceu no kibutz Guenigar no ano de 1936, registrou no arquivo do kibutz a visita dele à escola de Guenigar. E relatou a seguinte passagem: a professora Lea Aguzi ${ }^{120}$ segurava em suas mãos um desenho de um aluno pelo qual Korczak se interessou. Era o desenho de um avião que sobrevoava os campos no inverno e semeava-os do alto. As palavras de Korczak ao observar o desenho foram assim registradas:

"Até quando, nós os judeus, vamos nos admirar com os sonhos? - no
momento da semeadura há uma ligação direta do homem com a terra".

\footnotetext{
${ }^{116}$ Amin Al-Hussaini nasceu em Jerusalém, foi um líder religioso muçulmano e oponente do domínio britânico e do estabelecimento de um"Lar Nacional Judaico" na Palestina. Participou da revolta árabe de 1936-1939 na Palestina e em 1941 encontrou-se com Hitler na Alemanha para conseguir apoio para sua causa.

${ }^{117}$ David Ben-Gurion (1886-1973), de origem polonesa, foi o Primeiro Ministro do Estado de Israel na data de sua fundação em 14/05/1948. Foi líder do movimento sionista socialista e um dos fundadores do Partido Trabalhista.

${ }^{118}$ Yishuv é um conjunto dos habitantes de uma cidade ou país.

${ }^{119}$ Rivka Livne, carta enviada a Aza Ronen de maio de 1983, registro ${ }^{\circ} 5149$, arquivo de Korczak. O postal original está nas mãos de Dvorah Livne. Esse encontro com Tali Shner foi inédito, pois foi a primeira vez em que foram publicadas as recordações de Rivka Livne In: SHNER, 2008, p.54 e 55.

${ }^{120}$ Tali Shner, em sua pesquisa de campo, foi entrevistar a responsável pelo arquivo do Kibutz Ganiger em 2004. Descobriu que a filha de Lea Aguzi, Débora, vivia no kibutz e tinha a idade de 10 anos na época da visita de Korczak. Lea era uma intelectual falava russo e recebeu Korczak no kibutz. Débora recorda sua emoção ao saber que ele era o escritor do livro $O$ Rei Mateuzinho I, um livro muito conhecido e querido pelas crianças do kibutz. Ela recordou que Korczak entrou em uma das salas de aula de alunos de 6 ou 7 anos e percebeu que um aluno aparentava não sentir-se bem. Como não falava a língua do menino, apenas o confortou, dando-lhe um beijo. In SHNER, 2008, p.55.
} 
Eu, naquele momento, percebi dentro do meu coração, que o encontro com Korczak nos dava uma simples certeza: um homem que ensina tudo em uma frase.

Naqueles anos da construção da Terra de Israel, a agricultura era fundamental para a sobrevivência e o desenvolvimento econômico. Nota-se que mesmo as crianças estavam engajadas neste objetivo e sua participação era ativa no compromisso o crescimento do kibutz.

Tali Shner (2008, p. 54) foi ao arquivo em 2004 do Kibutz Guenigar, além de coletar material, conheceu a filha da professora Lea Aguzi, chamada Débora. Esta tinha dez anos em 1936, data da visita de Korczak. Sua mãe, que falava o idioma russo, acompanhou Korczak em sua visita a Guenigar, á casa das crianças, á escola. Quando Shner entrevistou Débora, esta se lembrou da visita, pois as crianças gostavam muito do livro de Korczak, $O$ Rei Mateuzinho I, que era lido na escola e fora traduzido para o hebraico.

No texto de Korczak (1978, p. 82) intitulado "A nova epopéia”, ele relembra as anotações sobre a visita a Guenigar (KORCZAK, 1978, p.84):

"Uma coisa é o ritmo do concerto dos grilos nos campos dos vales, e outra é o ritmo da lua errante no céu, e outro é o ritmo dos ventos, do rebanho, dos ciprestes. Há música no silêncio da floresta (sua voz ecoa nas manhãs de Guenigar. Surpreend-mei, havia música no silêncio)”.

Korczak demonstra nestas palavras acima o encantamento pela beleza da natureza de Guenigar. Ressalta a importância do silêncio da natureza como fonte de prazer na antítese utilizada ao se referir à música do silêncio. Segundo Szpiczkowski (2002, p.56) há uma Mishná [ensinamento, repetição] no Talmud ${ }^{121}$ em referência dita por Shimeon ${ }^{122}$ ao silêncio que diz assim:

Todos os meus dias criei-me entre Sábios e não encontrei nada melhor para o homem do que o silêncio; não é a teoria o principal, mas a prática; e quem fala demais traz o pecado.

${ }^{121}$ 1) O estudo, em (oposição ao Maasse (ação); 2) Ensinamento (da escritura); 3) O conjunto de investigações dos Amoritas(Sábios judeus responsáveis pela Guemará) à Mishná. In Szpiczkowski, São Paulo: Humanitas, 2002, p. 192.

${ }^{122}$ Shimeon, filho de Raban Gamliel; ambos pertencentes à primeira geração de Tanaítas, período de 10 a $80 \mathrm{dC}$. 
Korczak sempre valorizou a influência positiva da natureza no desenvolvimento emocional e físico da criança. Além de as colônias de férias propiciarem esse ambiente saudável e terapêutico também ofereciam o contato com uma paisagem que transmitia momentos de paz e silêncio. Este silêncio muitas crianças não tinham oportunidade de usufruir devido à pobreza em que viviam em Varsóvia. Já as crianças do Kibutz Guenigar nasciam neste ambiente próprio para o desenvolvimento saudável.

No boletim de Ein Harod do dia 30 de julho de 1936 está escrito:

Nesta noite às oito e meia, continuou a palestra na escola com Korczak. No terceiro dia iniciou com o tema sobre como explicar à criança o tema do nascimento do ser humano e respondeu a várias perguntas sobre este assunto. Nesta palestra se expressou não somente como um médico experiente e educador, mas também como um poeta, que sabia transmitir aos ouvintes o sentimento profundo dessas questões e as emoções sobre o segredos da vida. Uma grande plateia esteve presente nesta palestra.

A visita de Korczak despertou muitas dúvidas: Saberemos aproveitar sua visita? Será que o nosso departamento de educação saberá trazer uma programação de palestras? Será que estaremos em contato mais próximo com os educadores das diferentes instituições? Quem se ocupará de transcrever todas as palestras? E talvez fosse preciso que todos recebessem uma cópia das palestras? [...] Saberemos utilizar o conteúdo das palestras em favor de nossa educação comunitária sem ser um ensino individual? (SHNER, 2008, p.55)

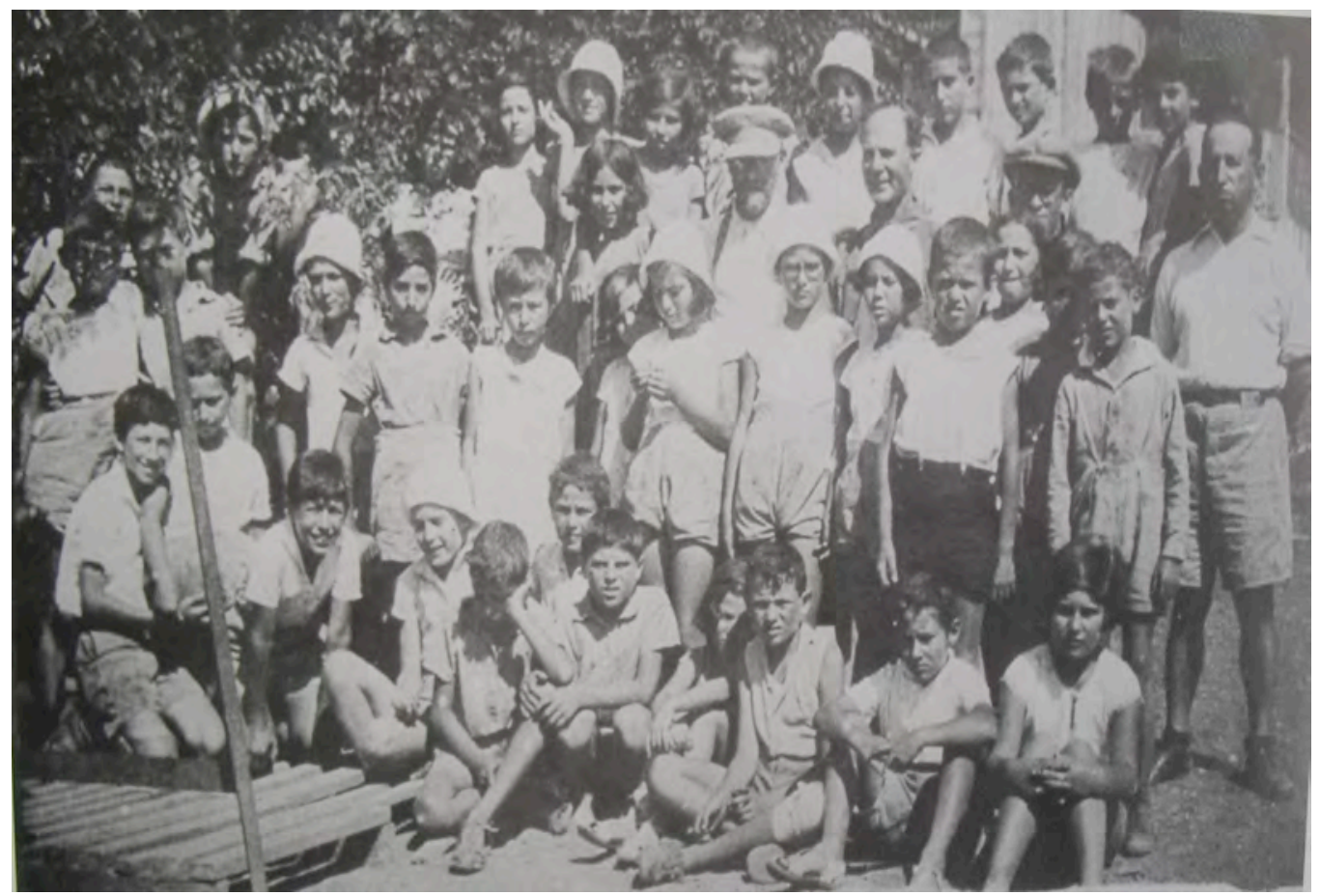

Imagem 34 - Korczak em 1936 com as crianças e educadores de Ein Harod Fonte: Beit Lohamei Haghetaot. 
A partir desse registro, percebe-se a influência de Korczak sobre os membros de Ein Harod devido aos questionamentos referentes à continuidade da reflexão educativa. Os jovens educadores tinham necessidade de aprendizado e treinamento, pois as crianças eram educadas principalmente nas instituições do kibutz.

Estes, de acordo com Arie Or, ${ }^{123}$ o berçário recebia os bebês a partir de dois meses de idade eram cuidados pelas metaplot [cuidadoras] durante o dia, durante a noite as mães se revezavam em turnos para cuidar de todo o berçário, incluindo os que estavam doentes. Os bebês passavam três horas diárias com os pais da $16 \mathrm{~h} 00$ às $19 \mathrm{~h} 00$. O trabalho das mães era designado para lugares próximos ao berçário, tais como a lavanderia, o refeitório ou o próprio berçário. As crianças, dos três aos 6 anos, permaneciam no pré beit yeladim. Dos seis até os nove anos, mudavam-se para o beit yeladim [casa das crianças] em grupos de 14 a 20 crianças por casa, com refeitório próprio e classes de três ou quatro por dormitório. Havia uma professora e uma cuidadora que dormiam junto com as crianças. A rotina das crianças começava às seis da manhã, e comportava funções fixas diárias como: arrumar o quarto, limpar a casa, o refeitório e a classe. Os pequenos cuidavam dos animais da pequena fazenda anexa à casa das crianças: uma vaca, um burro, patos e galinhas. Além disso, cuidavam da pequena horta onde cultivavam verduras e legumes.

O banho era coletivo até os nove de idade. Das $14 \mathrm{~h} 00$ às16h00, todos eram obrigados a descansar e permanecer em rígido silêncio. Às $16 \mathrm{~h} 30$ iam para o heder [quarto] dos pais e lá permaneciam até as $19 \mathrm{~h} 30$. Na casa dos pais havia um quarto de dormir, sala, banheiro e uma pequena varanda. Após jantarem com os pais no refeitório comunitário, as crianças retornavam para o beit yeladim e os pais contavam-lhes historias antes de dormir. Não era permitido dormir na casa dos pais. A partir dos dez anos, além das atividades rotineiras de limpeza, recebiam maiores responsabilidades, como alimentar os animais no período da tarde. A partir dos doze anos já podia trabalhar junto com os adultos no curral, no trator e na colheita. Aos doze anos, iam estudar fora do kibutz em escolas regionais e passavam a morar na shikun neurim [bairro dos jovens]. Esse espaço tinha quartos para duas pessoas e um banheiro, e namorados podiam dormir juntos. Quando se alistavam no exército, cada jovem recebia seu quarto com cama de casal e um banheiro individual.

Nesse contexto, fica evidente a importância das discussões sobre educação e da necessidade de reciclagem pedagógica constante. As crianças do kibutz tornavam-se

\footnotetext{
${ }^{123}$ Entrevista em 11/05/2011
} 
independentes e autônomas desde tenra idade, porém a necessidade de suporte emocional era inegável para aliviar as tensões causadas pela falta de proximidade familiar.

No boletim da Kvutzat Gueva ${ }^{124}$ de 11 de novembro de 1983 escreveu A. Halevi sobre o encontro com Korczak no ano de 1936 (SHNER, 2008, pp. 57-58):

\section{Muito emocionado contei a ele (para Korczak) sobre a Terra de Israel}

[...] Num certo momento passou um carro que ia para Ein Harod, e ele perdeu a carona para continuar a conversa.... E falou que esperaria o próximo veículo. Em seguida passou um carro para Afulah e novamente perdemos a carona. De repente o seu rosto mudou - e um nervoso estampou-se em sua face. E ele me disse: estou muito bravo com você.

- Que fiz para você? Perguntei.

- Estou bravo por você não ter feito nada. Ele me disse.

- No início dos anos de 20, quando você veio para a Terra de Israel, deveria ter vindo a mim e segurado minha garganta e dito:

- Eu estou indo para Terra de Israel, não sei o que farei, mas obviamente você vem comigo [...]

- E eu teria ido...

Korczak apresentou, ao longo de sua vida, uma inspiração cômica e demonstrou, nesse encontro, uma atitude divertida e surpreendente. Sua trajetória de vida mostra muita abertura para novas experiências e conhecimentos. Nesse sentido, vimos como em suas duas viagens à Palestina, com a idade de 54 e 56 anos respectivamente, demonstra essa avidez pelo novo e a vontade de vir a morar naquela terra. Mas também podemos perceber pelo diálogo acima que a iniciativa de deixar a Polônia teria sido mais fácil se fosse 16 anos mais jovem. Em 1920 ele tinha 42 anos e, provavelmente, teria mais disposição para uma mudança tão profunda em sua vida, pois ainda não estava tão envolvido nas diversas áreas em que atuou.

David Samhoni conta que na segunda visita à Palestina, Korczak se interessou pelo Moshav, e foi visitar Beer Tuv'ia onde tinha um amigo chamado Mot'ie Braverman (SAMHONI, 1957 apud SHNER, 2008, p. 56). No arquivo de Beer Tuv'ia não foi encontrado um registro dessa visita, mas Shner $(2008$, p. 46) procurou o filho de Braverman, chamado Hanan, que ainda vivia no Moshav, e nesse encontro descobriu que Korczak era amigo íntimo de seu pai, e haviam se conhecido no ano de 1935, na viagem que seu pai fizera à Polônia.

\footnotetext{
${ }^{124}$ Kvutzat- kibutz pequeno em formação.
} 
Hanan definiu Mot'ie Braverman como um moshavnic ${ }^{125}$ e mapa'amnic ${ }^{126}$, um boêmio, homem do teatro e do livro. Com eles, nessa viagem, estavam Abraham Shlonski ${ }^{127}$ e Emanuel Harusi ${ }^{128}$. Naquela época Hanan tinha 5 anos, mas recorda-se bem desse encontro amistoso entre seu pai e Korczak.

Além disso, Korczak visitou uma editora do jornal Davar Layeladim [A palavra da criança] e conheceu o editor Itzkhak Iatsiv, que registrou esse encontro no artigo do jornal de 10/12/1937 (SHNER, 2008, p.56). Nesse encontro, Korczak conversou e trocou ideias sobre a produção de um jornal infantil, enfatizando que a edição do jornal infantil deveria ser feita pelas crianças com a supervisão e o incentivo de um editor adulto aos escritores infantis para a publicação de seus artigos.

Nesse aspecto, a experiência bem sucedida vivida por Korczak na edição do encarte infantil do jornal polonês Mali Psheglond lhe deu segurança para transmitir seus princípios. Este encarte foi criado em 1926 (LIFTON, 2005, p.176) e realizado pelas crianças judias e católicas polonesas com a intenção de criar uma ferramenta de comunicação entre o público infantil.

Itzkhak Iatziv registrou seu encontro com Korczak em Plonsk no ano de 1937, na Polônia, onde ouviu uma das palestras na conferência de Korczak sobre a Terra de Israel destinada a um público de pais e crianças. Iatziv descreveu o que Korczak lhe falou particularmente após o evento:

"Sobre a criança que lá cria sua aventura infantil do nosso tempo. Elas
estão realizando uma vida judaica nova, envolvidas numa terra distante, e
provenientes de várias diásporas espalhados por todas as terras do
universo. E eis que a criança absorve todas essas coisas que ficam
transparentes em sua alma [...] é necessário ajudar para que ela possa se
expressar. É necessário organizar um questionário para estimular a
criatividade da criança em direção a sua nova aventura" (SHNER, 2008,
pp.56-57).

Moshe Zertel (apud SHNER, 2008, p. 57), do Kibutz Ein Shemer, encontrou-se com Korczak na Polônia logo após seu retorno da segunda viagem à Palestina e relatou as impressões de Korczak:

\footnotetext{
${ }^{125}$ Em hebraico: aquele que habita num moshav.

${ }^{126}$ Em hebraico: aquele que acredita no partido sionista trabalhista mapam.

${ }^{127}$ Shlonsky(1900-1973), foi um importante poeta de origem russa que se refugiou em 1921na Palestina.

${ }^{128}$ Emanuel Harussi(1903-1979) estudou medicina em Odessa, escreveu poemas e histórias em 1924, refugiouse na Palestina, onde atuou no teatro satírico.
} 
"Na sua sede bebeu todas as descobertas da realidade da Terra de Israel, impressionou-se com a sua paisagem e o seu idioma. Adorou o azul celeste do mar à tarde e o brilho das estrelas à noite [...] entendi que acima de tudo ele queria amar a terra, e queria se apegar a ela(dar ênfase a sua origem). Sua imaginação criativa acompanhava-o com um realismo concreto. Ele ansiava ambivalente pela Terra de Israel na sua majestosa ancestralidade e na sua colonização atual.

"No seu passeio no vale entrava nos dos campos, e tentava entender melhor a Bíblia Judaica, os espinheiros e figueiras". (SHNER, 2008, p.57)

No seu relato, Zertel acrescenta que Korczak estudou por longos anos a Bíblia Judaica [Tanach], mas, somente nas suas visitas à Terra de Israel, pôde compreender as histórias, paisagens, ventos, as plantas e seus significados. Ele pretendia se instalar em Jerusalém por um ano junto com a Bíblia Judaica, um dicionário, lápis e papel e erguer um monumento a criança órfã na Terra de Israel. Escreveu que em Jerusalém deveria ser instaurada uma unidade internacional como centro do pensamento e de inspiração. Questionava assuntos como a agricultura, o comércio, as fábricas e o saneamento. Demonstrava dificuldade para entrosar-se nas condutas do ensino educacional, sugerindo que o ensino comunitário do kibutz poderia ser falho na questão da liberdade e da vida independente. Seu encontro com a ação sionista foi importante para constatar que era uma atitude real e não apenas um sonho. Zertel acompanhou Korczak em suas visitas a Mishmar Haemek, Afula, Haifa, à cidade de Izrael e aos bairros de Carmel.

No arquivo da Kvutzat Haoar Haoved (grupo dos jovens trabalhadores) na cidade de Naan registrou a visita de Korczak $^{129}$ :

Ontem veio a Naan pessoalmente um escritor e educador Janusz Korczak, reconhecido na Polônia no campo da educação e pesquisador da alma infantil. É um líder das instituições educacionais da Polônia. E ativo na literatura. Ganhou um prêmio internacional da literatura infantil. Um de seus livros "O Rei Mateuzinho I" foi traduzido para o idioma hebraico. Já é a sua segunda visita à Terra de Israel. Está hospedado em Ein Harod. Visitou diversos lugares e proferiu palestras sobre a educação das crianças. Na noite de ontem houve uma palestra com a sua participação. Ele falou em polonês e russo alternadamente e foi preciso encontrar muitas alternativas para fazer a tradução. Nesta manhã visitou a casa das crianças. E Samhoni de Ein Harod o acompanhou.

${ }^{129}$ Registro ${ }^{\circ} 1571$, Arquivo de Korczak. 
De Naan prosseguiu viagem para Guivat Brener e no diário do kibutz do dia 16/08/1936 (SHNER, 2008, p. 58):

\begin{abstract}
"Houve na casa de cultura, nesta noite, uma palestra sobre as questões educacionais para pais e para os trabalhadores das casas das crianças. A palestra foi dirigida pelo Dr. Ian Korczak (perito nas questões educativas na Polônia). A palestra seguiu por oito horas e meia. Pessoalmente acredito que não há documentação sobre as anotações dos membros dessa palestra”.
\end{abstract}

No arquivo do Kibutz Yagur no diário do dia 3/8/1936, Shner encontrou o seguinte trecho ${ }^{130}$ :

"O amigo Janusz Korczak, ativista comunitário e pedagogo conhecido na Polônia, hoje é o nosso convidado. De noite fará uma palestra sobre questões educacionais. A palestra será proferida no idioma russo e traduzida para o hebraico".

O diário do dia seguinte, apresentava este registro:

"Na noite anterior nos admiramos com o conhecimento da vida do bebê foram uma festa as palavras que saíram de sua boca [...] Foram feitas muita questões e as respostas foram a palestra em si. Trarei para cá duas luzes que o amigo Korczak transmitiu numa conversa particular depois da palestra:

1) A organização da vida do kibutz é vantajosa no acúmulo de experiência nos cuidados infantis. As jovens mães podem trocar ideias com as mães maduras porque já criaram gerações de crianças.

2) É uma grande vantagem no kibutz que as crianças estão sob cuidados médicos de apenas uma pessoa, que é o medico do próprio kibutz. E este não depende da procura de pacientes particulares.

No diário de Korczak (1985, apud SHNER, 2008, p.62), Shner traz um trecho de um capítulo em que ele comprova sua ligação com Kfar Guiladi. Nessa passagem, Korczak estava se referindo à recuperação do tifo que o acometeu depois da Primeira Guerra Mundial:

"Durante o tifo tive uma visão. Uma imensa sala de teatro ou de concerto. Uma multidão de trajes de festa. Faço um discurso sobre a guerra, a fome, os órfãos, a miséria. Falo em polonês. Um intérprete traduz minhas

${ }^{130}$ Arquivo do Kibutz Yagur, registros das p. 142-143. 
palavras para o inglês. (a coisa se passa na América). De repente a minha voz se quebra. Silencio. Depois, em um lugar, do fundo da sala, um grito. Régine $^{131}$ corre em minha direção. Ela para em frente ao estrado, joga o seu relógio sobre o tablado, exclamando: eu the dou tudo que tenho! Chuva abundante de notas, de ouro e de jóias. Jogou-me anéis, pulseiras, colares. Os rapazes do orfanato apareceram em cena: os irmãos Gelblat, Falka, Majer, Kulawski, Gluzman, Szejwacz; eles enviam tudo em colchões. Comovido, o auditório grita, aplaude, chora.

Não tenho muita confiança em profecias, contudo espero já há vinte anos que esta visão se torne realidade.

Régine, contarei a sua historia quando falar dos estranhos destinos dos pupilos da casa branca da Rua Krochmalna, na cinzenta cidade de Varsóvia.

Portanto, uma vez de posse destes meios ilimitados, abro um concurso para a construção de um grande orfanato nas montanhas do Líbano, na proximidade de Kfar Guiladi.

Existirão aí salas de jantar e dormitórios imensos, como nos quartéis. E também "casinhas de eremitas". Reservo para meu uso pessoal um quartinho com paredes transparentes, situado na superfície plana do teto, a fim de não perder um sol nascer, nenhum pôr-do-sol e também para poder escrever à noite, levantando os olhos de vez enquanto, em direção das estrelas.

A jovem Palestina procura pôr-se de acordo com a terra, consciente e laboriosamente. "Mas virá o dia, quando deverá se entender com o céu".

No arquivo de Kfar Guiladi não há todo o registro da visita de Korczak, pois, este só foi iniciado no ano de 1938. A arquivista do kibutz indicou a Shner dois de seus membros do kibutz que ainda se lembravam da visita: Uri Horovicz e Rachel Segal-Rabinovicz. Eles tinham 10 anos na época e se lembravam de que Korczak ficou por três dias no kibutz no ano de 1936. Ele visitou os dormitórios, as salas de aula, a sala de trabalhos manuais, a biblioteca, a sala de descanso e participou com as crianças das atividades no curral. Uri contou que na classe havia crianças abandonadas que viviam no internato do kibutz. Korczak se interessou pelo cotidiano no internato e fez muitas perguntas. "As crianças o reconheceram como o autor do livro O Rei Mateuzinho I', afirmou ele. Rachel, por sua vez, contou que Korczak foi ao kibutz para encontrar seu pai, Mordechai Segal, um educador dos pioneiros do ensino

\footnotetext{
${ }^{131}$ Uma das ex-pupilas do Orfanato que, com fortes dons musicais, partiu para estudar em Viena e depois imigrou para os Estados Unidos.
} 
integrado dos kibutzim para conversar sobre essa modalidade de instituição pedagógica. Naqueles anos, tudo era vivido em sociedade e as crianças ficavam somente durante três horas por dia com pais.

Mordechai Segal (1955, apud SHNER, 2008, pp. 59-60) escreveu em seu livro Ensaios da educação sobre essa visita:

"Jamais esquecerei um visitante - Janusz Korczak, Zichrono Levrachah [de abençoada memória]. Eis que senta entre as crianças, faz perguntas simples sobre suas vidas e conta as historias do seu orfanato em Varsóvia. A conversa se mantinha natural e espontânea, mesmo diante da necessidade de tradução simultânea. $O$ que vocês fazem quando duas crianças estão brigando? e as crianças respondem com uma pergunta: e o que vocêfaz? Eu fico olhando pela janela: se as forças forem iguais, vão se cansar até parar, mas, se um for maior que o outro - coitado do "bagunceiro"! E um espírito de justiça brilhou em seus bons olhos".

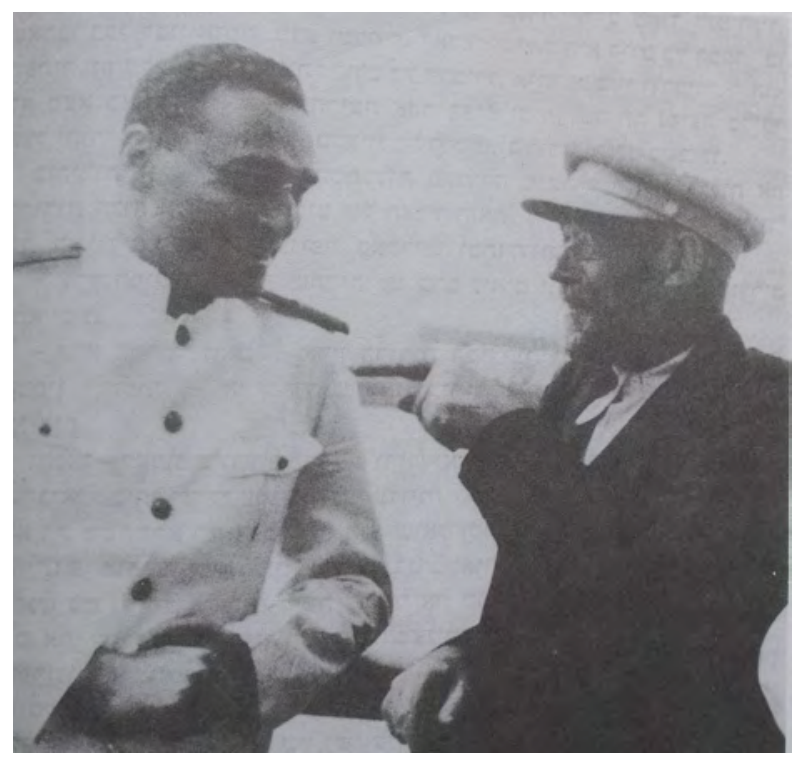

Imagem 35 - Korczak no caminho de volta da Palestina em 1936. Fonte: PERLIS, 1986, p. 132. 


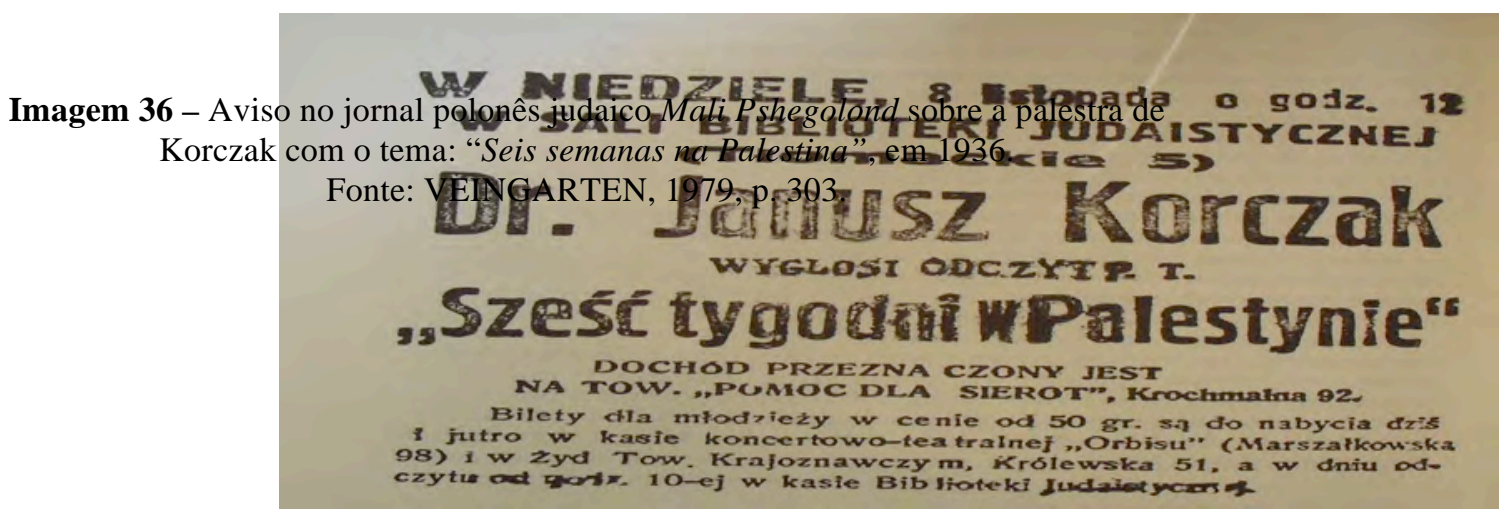

As anotações de Korczak da sua segunda viagem estão em dois ensaios: "Rashamim Vehirhurim" (KORCZAK, 1978, pp. 85-94) - "Registros e Reflexões" e "Rashmei Eretz Israel" (KORCZAK, 1978, p. 89) -- "Registros da Terra de Israel". Essas anotações foram relatadas primeiramente numa conferência em Varsóvia, em novembro de 1936, e posteriormente publicadas.

No primeiro ensaio "Rashamim Vehirhurim”, Korczak (1978, p.86) escreve:

Quando tive minha primeira experiência indo em direção à Terra de Israel senti algo diferente mais do que uma surpresa, mais do que curiosidade, uma sensação de orgulho, de alegria [... ] nenhuma pessoa, nem meus pais - eu sou o primeiro -fui merecedor e cheguei a isso.

Com estas palavras percebe-se a emoção de Korczak de ser o representante de sua família a pisar pela primeira vez na Terra de Israel. Sua história de vida distante do judaísmo o fez chegar a esse encontro tão sonhado nas orações de seus ancestrais. Ele foi o pioneiro da família e o fez com orgulho, quando escreve que fez por merecer conhecer a Terra de Israel. Ele não recebeu dos seus pais uma base de educação, cultura e literatura judaica. A maioria dos judeus em Varsóvia tinha contato intenso com a língua iídishe, o hebraico e as canções sobre a Terra de Israel, tanto na liturgia quanto no folclore. Porém, apesar deste afastamento inicial, demonstrou uma ligação forte com a Terra de Israel, sem deixar de perceber as dificuldades vividas no cotidiano. Sobre o clima da Terra de Israel ele conta que é muito 
quente chamado hamsin [ventos quentes vindos do deserto], todo o tempo, só que se torna mais quente ainda para os que ficam ociosos. Fala sobre os ventos frios que sopram do mar e dos ventos ardentes das montanhas. Sobre os ventos de Ein Harod, Korczak os define como meus ventos ${ }^{132}$, provenientes do Monte Guilboá. Ele fala das estrelas da noite que conversam entre si uma língua estranha, a língua da Bíblia Judaica, sobre seus assuntos eternos, difíceis e cheios de segredo.

Talvez por isso os homens fujam das vozes das estrelas e as silenciam um pouco ali um pouco aqui, através dos prazeres da carne. (KORCZAK, 1978 apud SHNER, 2008, p.60)

Por essa metáfora de Korczak, podemos presumir que de noite as vozes falam alto. Durante o dia a muito que fazer; o trabalho e a vida comunitária exigem quase todo o tempo de que o individuo dispõe. Além disso, os dias são acompanhados de preocupações incessantes de segurança por causa dos conflitos com os árabes. Os jovens pioneiros, na ânsia da construção da terra, abdicam de seus prazeres para seguirem firmes em seus objetivos. Sua missão incansável faz parte do plano da conquista de sua terra e de uma nova identidade. Korczak (1978, pp. 195-196) escreve:

Quanto tempo dura a gravidez, que ao final transformará o judeu da diáspora num cidadão da pátria antiga e nova? - ao que parece são três anos.

No primeiro ano - uma situação de estranhamento permanente;

No segundo ano - sentimentos de desespero e revolta alternados. E momentos apimentados de saudades;

No terceiro ano- cresce o silêncio, pois a terra já lhe pertence, - o trabalho, o céu, a respiração e o suor.

O ensaio dos "Registros da Terra de Israel" é composto por 940 anotações que Korczak registrou durante sua segunda viagem à Palestina, e é uma extensa observação de experiências diversas vividas na Terra de Israel.

${ }^{132}$ Ibidem, p.89. 


\subsection{Cartas de 1936 a 1939}

\section{Documento $^{\circ} 15$ - Carta de Korczak enviada a Ester Budko em 9/12/1936 \\ "Eu nunca me senti intimamente ligado à vida-ela simplesmente fluiu em mim [...] Desde a minha infância eu me sinto velho e supérfluo. É de se admirar que este sentimento se tornasse mais intenso agora? Eu não estou contando os dias, mas as horas que me restam. A viagem para Palestina foi meu último esforço. E agora nada. Eu acredito no futuro da humanidade. Se eu mantivesse minha fé em Deus, provavelmente rezaria pela salvação deste mundo onde as crianças são as primeiras a sofrer. A criança terá o papel principal na renovação espiritual da humanidade - essa era a minha intenção de fazer parte, mas não sabia como". (KORCZAK, 1978, pp. 195-196)}

\section{Documento $n^{\circ} 16$ - Carta de Korczak enviada à família do Dr. Lichtenshtain em 29/3/1937}

Notáveis e bondosos, amigos e senhora:

Vou escrever resumidamente [...] Depois da minha depressão que durou meses - decididamente quero fazer uma última experiência: passar os últimos anos de minha vida na Terra de Israel, ficar um ano em Jerusalém aprendendo o idioma hebraico, para depois ir ao Kibutz [...] da minha família sobrou apenas uma irmã [...] essa viagem precisa acontecer em um mês, pois a situação no momento não é promissora. (KORCZAK, 1978, pp. 197-198)

A realidade que Korczak estava vivendo em Varsóvia era desanimadora. Em 1935, após a promulgação das Leis de Nuremberg que declaravam serem os judeus uma raça inferior, acelerou-se a deterioração da relação dos poloneses com os judeus. Encorajados pelos grupos de nacionalistas radicais, os poloneses aceitaram os boicotes aos estabelecimentos judaicos e a segregação dos estudantes judeus nas universidades.

A imprensa direitista usava os artigos de Korczak sobre a Palestina para identificá-lo como o Velho Doutor ${ }^{133}$. Na realidade, o bom polonês Janusz Korczak era o judeu Henryk Goldszmit. E oportunamente levantavam dúvidas sobre sua viagem à Palestina e capacidade dele de educar crianças polonesas.

\footnotetext{
${ }^{133}$ Personagem de Korczak numa emissora de rádio em Varsóvia iniciado em 1934. Esse programa diário de 15 minutos era muito popular, pois o tema era educação, crianças e conflitos familiares.
} 
Korczak estava triste com o ataque da imprensa sobre sua viagem à Palestina, mas ainda não tinha ideia do que o esperava no Orfanato Nasz Dom, Nosso Lar (LIFTON, 2005, p.223). No final de 1936, rompeu seu trabalho com Maryna Falska por diferenças filosóficas no método educacional. Por outro lado, na reunião do conselho do orfanato, Korczak foi questionado por um dos membros se ele era sionista. Esse questionamento tinha o objetivo de levantar dúvidas sobre sua lealdade polonesa. A conseqüência disso foi o fato de Korczak ser impedido de educar crianças polonesas.

É importante ressaltar que a maioria dos membros do conselho apoiou a saída de Korczak, com a justificativa de que, por mais que ele fosse assimilado, ainda era um judeu. Para evitar escândalos, seu nome não foi retirado do quadro de funcionários e, para as crianças, foi dito que o Dr. Korczak não tinha condições de comparecer ao orfanato como de costume.

Neste mesmo ano de 1936, Korczak perdeu o emprego no programa de rádio e o posto de consultoria da corte juvenil sob a ordem oficial de que nenhum judeu poderia ser responsável pelos delinquentes juvenis (LIFTON, 2005, p. 224). Todas essas perdas profissionais e pessoais abalaram a vida de Korczak a ponto de fazê-lo reviver as dores da infância.

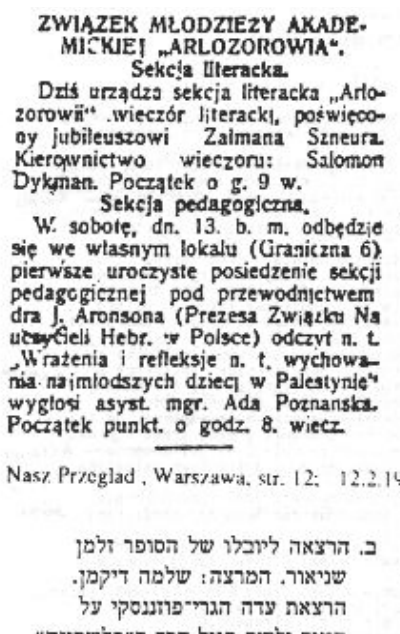

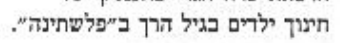

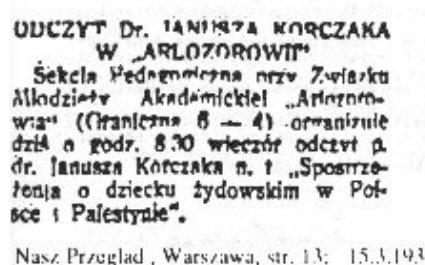
is $\mathrm{Na}$
WECZOR GORDONA W AKAD. ZW. MLODZIEZY "ARLOZOROWIA". Dziś O g. 8.45 w. odtędzie sis we wlasnym lokalu (Graniczna $6 \mathrm{~m}$. 23, lewa oficyna, 3 pietro) wieczór, poo swieccony parnięci A. D. Gordona. Biorn udzial: Delegat z Palestyn Szapiro oraz Szewach Eizenbund.

Nasz Pricglad, Wars/awa, str. 12: 5.2 .1937

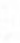
טחבר הספר.

ODCZYT DOC. Dr, GUSTAWA BY. CHOWSKIEGO $\dot{W}$, GARLOZORO. Dnia 3 marca (śoda) odbedrle sie w Arlozorowil -Graniczna $6-4)$ odczyt Doc. U. J. P. Dr. G Bychowskiego n. $t$.Psychoanaliza a wychowanie nowego ezhowieka". Początek o godz. 8,30 wieczór. Po roźpoczęciu odezytu drzwi na sale Uwaga: Odezyt zostal przesurięty. Uwaga: Odezyt zost

$2 \mathrm{e}$ wtorku na.srode 


\title{
Documento $n^{0} 17$ - Carta enviada por Korczak a Moshe Zilbertel em 30/03/1937:
}

\begin{abstract}
“... Tenho uma vida impessoal como se vivesse em outro planeta. Estou vivendo uma comédia satânica que está em meu pensamento e não consigo romper o contato com essa realidade atual polonesa. Vou continuar atento a cada leitura e sons que ouvir. (...) Sei que vou ficar comparando tudo entre lá e aqui, vai ser difícil, mas vai ter de acontecer. (...) Sou um velho cansado e sem recursos e vou tentar um último teste, um esforço grande como se fosse um decreto do destino. É assim sem mais nem menos em maio eu vou para Eretz Israel e Yerushalaim ${ }^{134}$. Em 1937 vou ficar um ano por lá, aprendendo a língua. Por ora cortei todos os meus laços e só sobrou uma plateia me observando. Hoje só posso consumir, não posso agir. Leio o que outros escrevem e não tenho permissão para debater. (SHNER, 2008, p.18)
\end{abstract}

Na carta enviada para seu amigo, Moshe Zilbertel ${ }^{135}$, demonstra a preocupação dois meses antes da sua possibilidade de imigrar para Israel, por causa das dificuldades financeiras pelas quais passava e de sua dificuldade com a língua hebraica.

A carta mostra a abrangência de seu dilema. Na Polônia tornara-se um ser passivo, apenas um observador apático, sem produtividade. Para um homem como ele, de grandes feitos, isso representava uma vida sem sentido, contrariando sua natureza, sua força física e espiritual.

Verificamos nessa carta que a ida para Israel seria como uma troca de exílio, pois ele promete a si mesmo que sempre estará vinculado e atento à Polônia. À medida que crescia o pensamento antijudeu, por volta de 1935, enfraquecia a relação de Korczak com seus amigos intelectuais da sociedade polonesa, o que era reforçado pelo afastamento de várias atividades que exercia frequentemente. Korczak era um intelectual ativo da elite cultural polonesa, um homem respeitado e integrado à sociedade. Mas, com o crescimento do antissemitismo, seus relacionamentos foram esfriando e ele foi obrigado a se afastar do programa de rádio no qual tinha um quadro famoso, chamado "O Velho Doutor".

Logo foi observada a solidão que Korczak enfrentou, descrita nas últimas cartas para os amigos e ex-alunos que emigraram para Terra de Israel. O processo de seu sofrimento chegou ao auge com a morte do Marechal Pilsudski em 1935, enfraquecendo a esperança da independência nacional.

\footnotetext{
134 Jerusalém.

135 Amigo de Korczak desde 1925, foi quem o aproximou do Movimento Juvenil "Hashomer Hatzair" em Varsóvia. Imigrou para a Terra de Israel em 1932 para o Kibutz Ein Shemer.
} 


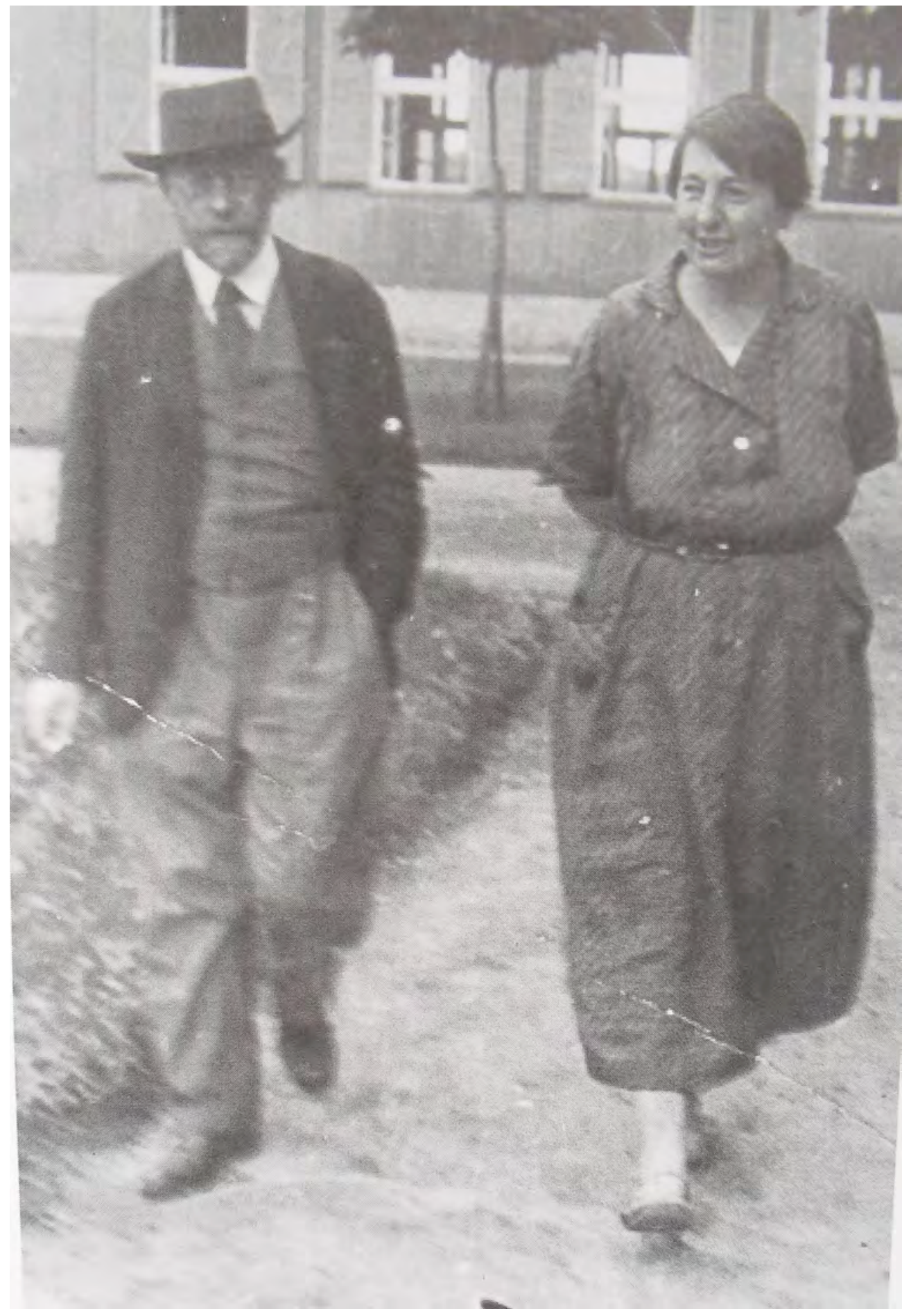

Imagem 38 - Korczak e Stefa na década de 1930 em Varsóvia. Fonte: Beit Lohamei haghetaot. 


\section{Documento n ${ }^{\circ} 18$ - Carta de Korczak enviada a Joseph Arnon em 02/08/1939}

Caro Jusek,

Durante os últimos meses estive além das fronteiras de espaço e tempo. Decidi refrescar-me (Banhos de Sal) e um mês como um jovem instrutor (novamente!) em um acampamento de verão. Dediquei o mês de terapia para uma historia palestina, no sentido de que escrevo uma conversa entre pai e filho na Terra de Israel, e eles falam da criança. Na segunda parte, a Terra de Israel tem um papel muito importante e é por isto que, se tiver dinheiro suficiente, farei uma visita de quatro meses em outubro - janeiro, dos quais, dois meses, planejo passar na velha Jerusalém (Em um interessante "heder" que eu vi lá, ou em uma sinagoga em Tiberias). Receio o reumatismo, os insetos, e um pouco os árabes (menos). Nada mais nada menos que um plano por uma nova Bíblia. Estou empenhado em realizá-lo. [...]

Voltei ontem. Ainda estou esgotado, mas alegre (se é apropriado dizer isto com 61...). Durante o adeus, depois da meia-noite, na floresta, a lua brilhava. As árvores desenhavam longas sombras, as crianças cantavam, recitavam agitadas com medo, pois haviam passado por um incinerador de tijolos (e dois bêbados os ameaçaram no primeiro dia: - Dê-me a pistola Chame Hitler.). Olhos arregalados, muita comoção, e o bater de pezinhos na areia, - O que se segue? Na Terra de Israel, sua historia não precisa fazer tal pergunta: você sabe. [...]

(O poeta) Zerubabel de Ein Harod. Como se protegeu astuciosamente para não cair vitima da primavera polonesa. [...] Tinha todo direito de não esconder suas saudades. [...].

Um sincero abraço e lembranças aos meus conhecidos e aos conhecidos imaginários.

Korczak (ARNON, 2005, pp. 97, 98,99).

Korczak vivendo na época da eclosão da Segunda Guerra, ainda tinha vontade de escrever, como se pode observar nesta última carta. Os temas escolhidos por ele são judaicos e bíblicos. A conversa de um pai com seu filho na Terra de Israel sugere a formação da segunda geração de halutzim na Polônia. De acordo com Korczak (apud SHNER, 2008, pp.25,26), o problema de identidade judaica diaspórica seria resolvido com a criança já nascida na Terra de Israel. Essas crianças educadas em língua hebraica e criadas com liberdade de expressão seriam o símbolo da construção de um novo mundo.

Demonstrando otimismo foi com os alunos para a última colônia de férias no sítio Little Rose em 1940. De acordo com Korczak (SHNER, T. 2009, p.73), na última noite da temporada se reuniu com as crianças para assistir ao por do sol e pronunciou-se desse modo: 
-Talvez não voltemos a Varsóvia? Talvez possamos nos organizar em duplas, pegarmos nossas bandeiras e sairmos em marcha cantando?

-Para onde?

-Para o sol.

-Vai demorar muito tempo...

- E o que importa?Dormiremos na grama e comeremos nosso pão.

Andaremos muito, muito tempo andaremos...

-E então o que acontecerá?Perguntaram os jovens com o cortar do vento.

Entretanto o sinal tocou chamando todos para o último jantar e a história ficou sem final...

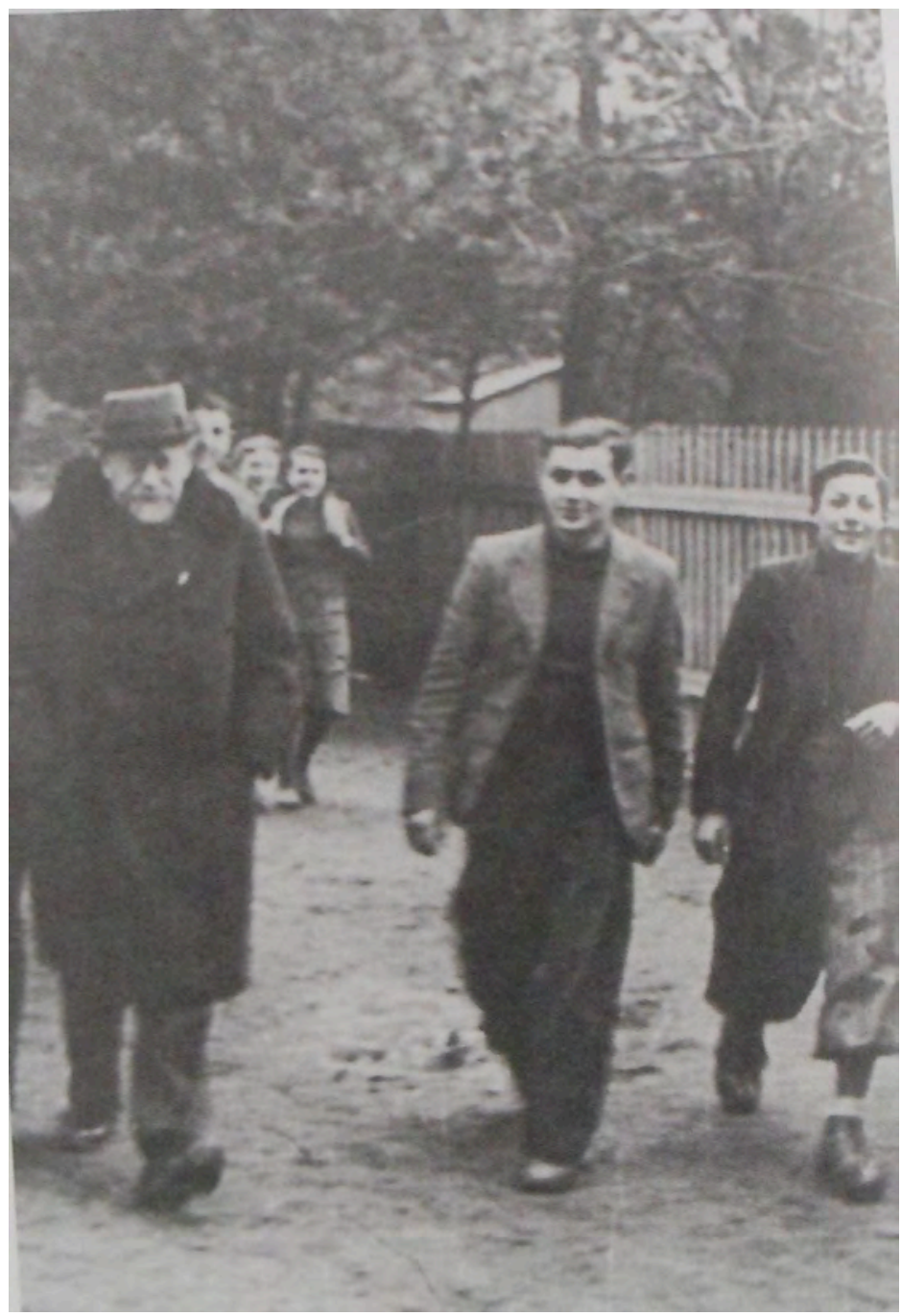




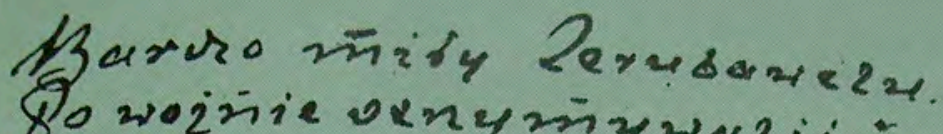

8

Surs

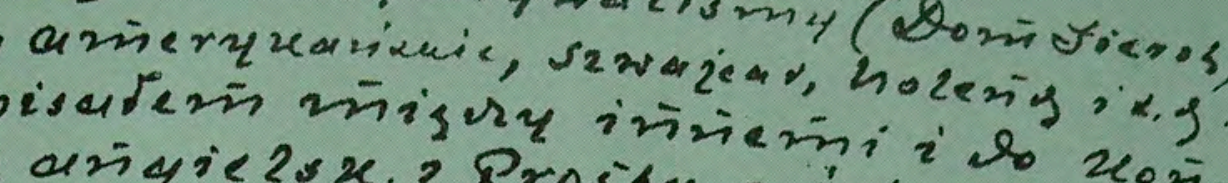

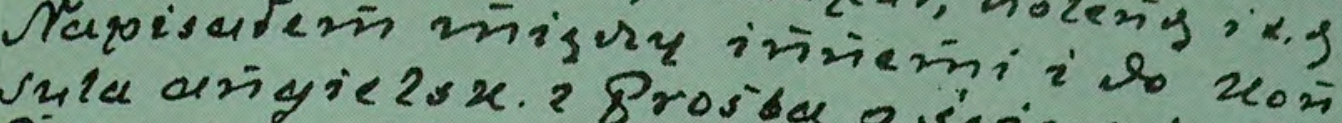

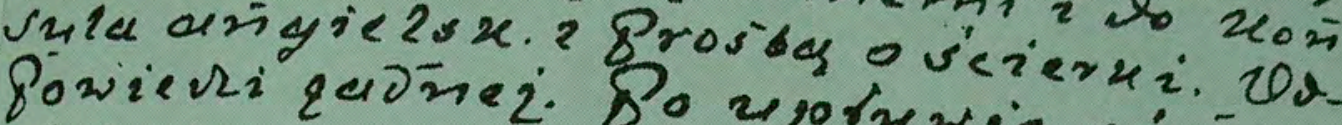

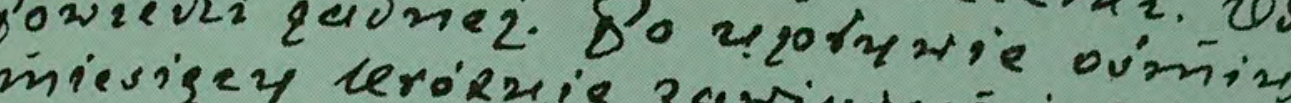

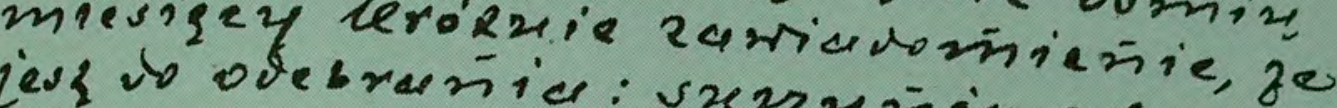

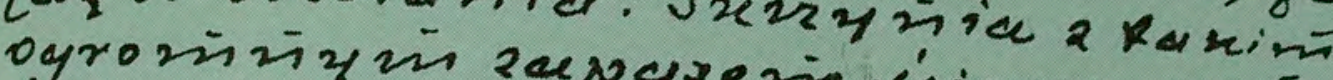
liksiei lav skarezm

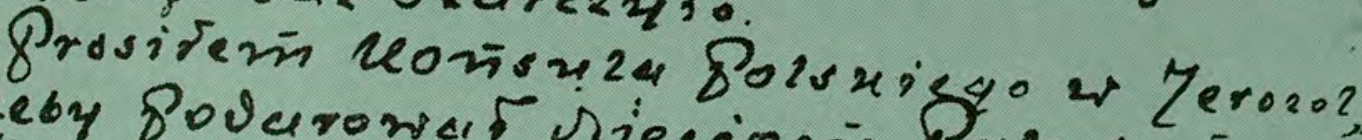

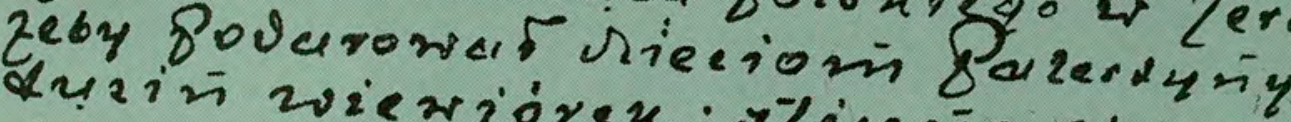

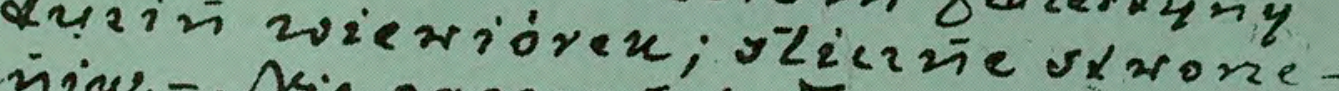

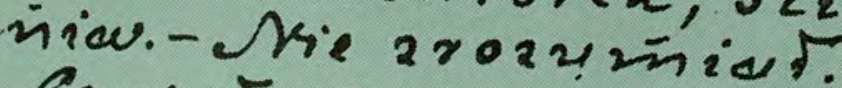

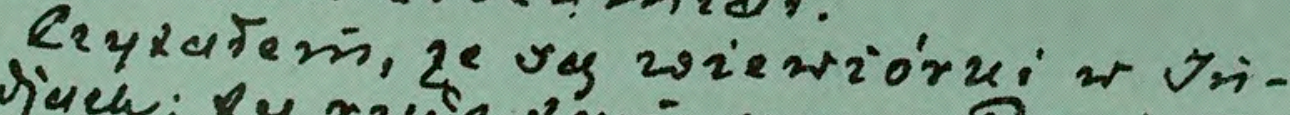

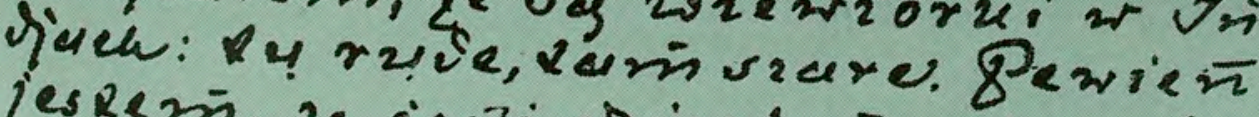

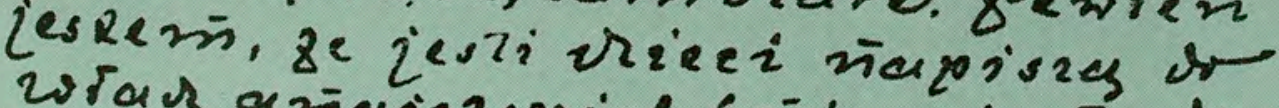

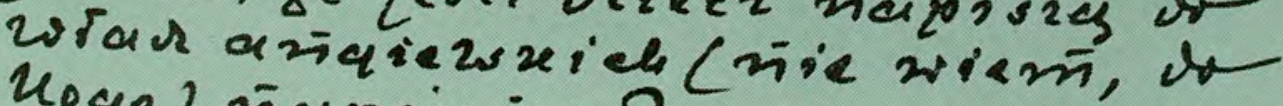

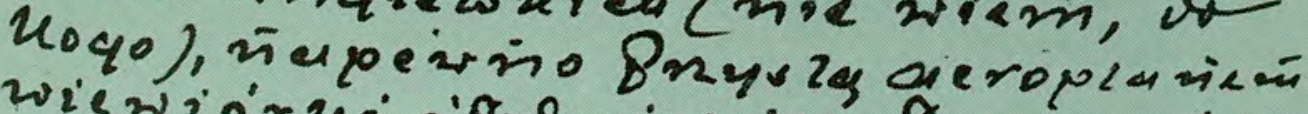

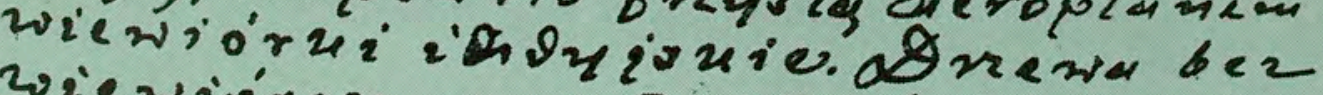
wientórex ss smisuñe i nieveren -

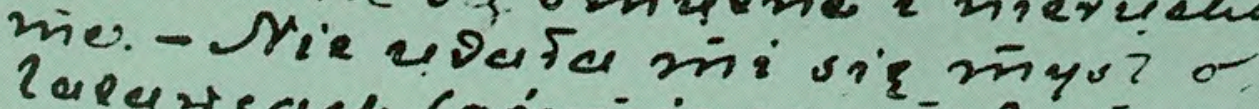

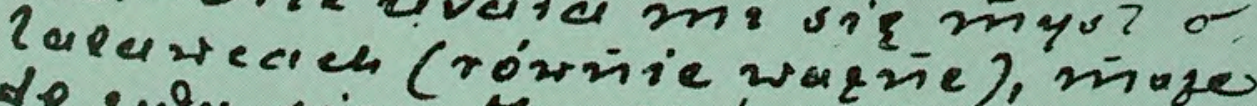

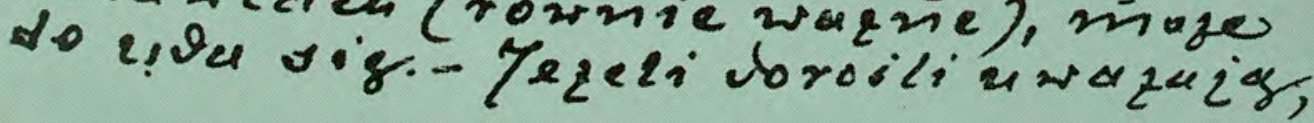

Imagem 40 - Cópia da última carta de Korczak para seu amigo de Ein Harod em 1939. Fonte: Beit Lohamei Haghetaot. 


\section{Considerações finais}

Janusz Korczak, judeu polonês, foi diretor de dois orfanatos em Varsóvia, um para crianças judias e outro para crianças cristãs, tendo se consagrado como um grande educador que defendeu os direitos das crianças. O presente trabalho teve por finalidade apresentar uma face da vida de Korczak que demonstra sua ligação com as ideias sionistas e consequentemente com a Terra de Israel. Nossa premissa baseou-se na trajetória de um judeu com identidade polonesa muito forte, que lutou em três guerras pela pátria. Era filho e neto de maskilim, iluministas judeus, que visavam à integração do judeu na sociedade maior sem perder a identidade judaica, mas os pais de Korczak foram além deste princípio, criando-o como um autêntico polonês sem vínculos com o judaísmo.

Na sociedade polonesa, Korczak era considerado um verdadeiro polonês, distanciado do judaísmo, e com livre acesso aos salões literários e encontros com a intelligentsia. Ele, no entanto, era ligado também à elite intelectual judaica de Varsóvia e se interessava pelo caminhar do movimento sionista, iniciado ainda no século XIX e que se fortalecia cada vez mais, participando dos encontros promovidos por Nahum Sokolov e I.L.Peretz. Com o avanço do movimento nacionalista europeu decorrente da Revolução Francesa, passou a se interessar e se aproximar das ideias sionistas trazidas pelos jovens educadores do orfanato judaico que ele dirigia com o apoio de sua assistente, Stefania Wilczinska.

Neste estudo, apresentamos uma análise, ainda que parcial, da documentação sobre as duas visitas de Korczak à Palestina, em 1934 e 1936. Nessa análise foi possível encontrar aspectos relevantes sobre sua percepção em relação à Terra de Israel, no modo como ele se referia à terra de seus ancestrais. Encontramos referências nos documentos sobre seu dilema, relativo à dupla identidade de polonês e judeu. Acreditava na integração entre judeus e poloneses para a construção de uma sociedade justa e pacífica, assim como seu pai e avô pretendiam. Entretanto, ele enfrentava duas forças opostas e resistentes: a primeira, o antissemitismo da sociedade polonesa, e a segunda, a resistência da comunidade judaica ortodoxa em se abrir para o mundo secular. 
Korczak se preocupava com o futuro das crianças polonesas independentemente da religião que possuíam, instaurando um sistema educacional democrático nos dois orfanatos. No orfanato judaico, enfrentava o desafio de ensinar a língua e literatura polonesa para crianças que tinham como língua vernácula o iídishe. Concomitantemente com a ascensão do movimento sionista, a língua hebraica também começou a ser ensinada, trazendo a Korczak um dilema sustentado em suas dúvidas sobre a possibilidade da integração do judeu na diáspora.

Na documentação de Korczak há referências às dificuldades de adaptação à nova terra, considerando as diferenças da língua, do trabalho, do clima, das diversas culturas, e o distanciamento da família. São diferenças que exigiam do indivíduo um desligamento rápido das raízes para alcançar a adaptação e a aculturação ao novo lugar. Por outro lado, destaca a Terra de Israel como um lugar de encontro com a ancestralidade judaica, um passado histórico comum e um facilitador para começar o enraizamento. Não é por acaso que Korczak compara essa adaptação ao plantio de uma árvore, que demora alguns anos para formar as raízes e sobreviver a qualquer tempestade. Ele levanta a questão sobre a possibilidade de a Terra de Israel servir como um refúgio do crescente antissemitismo na Europa. Ao mesmo tempo, considera a Palestina como a possibilidade de concretização do sonho de uma nação que garante os direitos daqueles que vivem na diáspora e que não são aceitos como cidadãos iguais aos seus compatriotas. Sua percepção em relação à necessidade de aproximação do judeu diaspórico à Terra de Israel inclui uma visão metafísica que impulsiona a coragem do jovem pioneiro a enfrentar o desafio de uma terra pouco desenvolvida e fazer dela uma futura nação.

Korczak vislumbrava a Palestina como um lugar próspero com grande capacidade de desenvolvimento, devido à força de vontade dos jovens. Para ele, a Terra de Israel era um lugar onde, principalmente os jovens poderiam se encontrar e construir um novo lar nacional judaico. No entanto, devido à idade avançada e à falta do conhecimento da língua hebraica, ele temia tornar-se um fardo nesse empreendimento de jovens. Por outro lado, durante as duas viagens à Palestina na década de 1930, Korczak conheceu o estilo de vida do kibutz e a educação oferecida às crianças que aprendiam a viver em comunidade, e cujos deveres e obrigações eram partilhados de maneira igualitária, aventando a possibilidade de ele próprio se estabelecer na Terra de Israel. A ideia sionista trouxe a Korczak uma nova realidade da possibilidade de uma terra onde a criança pudesse se desenvolver plenamente livre de preconceitos e do isolamento social 
Neste trabalho, as impressões de Korczak sobre a Terra de Israel foram mostradas em artigos em jornal, correspondências, anotações pessoais, registros de amigos e atas dos kibutzim e moshavim. Destacamos um artigo, em forma de carta, no jornal infantil judaico Mali Psheglond de Varsóvia, escrito em 1926, oito anos antes de sua primeira viagem à Terra de Israel, em que Korczak convida as crianças da Palestina a se corresponderem com as crianças polonesas. Nessa carta, Korczak procurou aproximar a realidade vivida pelas crianças da Terra de Israel e conhecer como funcionavam as escolas, o trabalho no campo, as plantações de maçãs e uvas, a criação dos cavalos árabes e saber mais sobre as comemorações judaicas, especialmente a festa de Hanuká. Foram poucas crianças que responderam inicialmente, mas com o incentivo de duas educadoras do orfanato, Ester Budko Gad e Feiga Lipshitz, que imigraram para a Palestina em 1928, a correspondência se intensificou.

$\mathrm{Na}$ troca de correspondência com essas duas educadoras, Korczak se refere à precariedade do estilo de vida na Palestina, onde havia pouca opção de trabalho e despreparo para o cultivo agrícola, motivo que desencadeava frequentemente a desistência dos jovens de lá permanecer, e que levou muitos jovens a retornar à Polônia. Dentre as dificuldades ele aponta o desafio permanente de se ligar em as duas pontas da corda rompida nos mais de dois mil anos de diáspora, pois, nesse período de tempo de diáspora, a Palestina fora dominada por diversos impérios e encontrava-se pouco desenvolvida e quase abandonada sob domínio turco.

Além disso, na documentação é possível encontrar menção à prática de atividades no orfanato ligadas à Terra de Israel como, por exemplo, o ensino da língua hebraica, o Hatikvá (hino do movimento sionista), as danças típicas e o envolvimento com os movimentos juvenis. Korczak se refere à Terra de Israel como o lugar onde é oferecida à criança a possibilidade de expressar seus sonhos, temores, aspirações e perplexidades. Ele faz referência à amargura e ansiedade dos jovens pioneiros que eram, em sua maioria, corajosos e rebeldes, mas Korczak ressaltava a fé como componente vital para a manutenção do ideal. Ele também via a necessidade dos pioneiros de permanecerem comprometidos com a educação da criança como fonte de esperança para uma sociedade emancipada e justa.

Antes de visitar a Palestina, Korczak considerava o ideal sionista como uma utopia e o sionismo uma fase passageira. Mas quando conheceu de perto a coragem e a determinação dos Halutzim (jovens pioneiros), reconheceu que estava errado: ele considerou genuíno e sagrado o esforço desses jovens. 
O fato de Korczak não dominar a língua hebraica o incomodou na primeira visita, mas não o impediu de se sentir enriquecido pela aprendizagem adquirida em seus vintes dias no kibutz Ein Harod. Nesse sentido, Korczak aconselhava aqueles que, como ele, tinha dificuldade de adaptação à Terra de Israel, a ser persistentes ao longo de três anos, quando a pátria do passado ficaria na memória e abriria espaço para a nova "pátria". Segundo Todorov (1996, p.24): Toda ruptura e toda cisão não são uma fatalidade, e podem ser compensadas pela aculturação de que todos os seres são capazes.

Quando esteve na Palestina Korczak proferiu palestras para os educadores dos kibutzim e transmitiu seus conhecimentos médicos e educacionais. Ele despertou interesse entre os educadores do kibutz sobre a tarefa de educar democraticamente, exaltando a capacidade da criança de absorver uma vida judaica nova na Palestina. Além disso, ressaltou a necessidade de se estimular a criatividade da criança por meio da dança, das artes, da música e da literatura. Durante esses encontros, Korczak frequentemente expressava sua preocupação com a preservação da ancestralidade da Terra de Israel, ao mesmo tempo em que propunha uma interação igualitária das crianças judias com as árabes. Pare ele, as diferenças religiosas e culturais poderiam ser resolvidas por meio da educação.

Fazendo um paralelo com a história infantil que Guilat Shalit ${ }^{136}$ escreveu aos onze anos de idade, e seus pais publicaram no livro chamado: Quando o tubarão e o peixe se encontraram pela primeira vez, (2009), é possível relacionar o pensamento de Korczak com a metáfora utilizada por Shalit. No texto, o tubarão e o peixe quando se encontram pela primeira vez, ainda filhotes, desenvolvem um relacionamento natural de convivência pacífica. Ao retornar a seus lares é a família que reprime tal relacionamento. A mãe do peixe considera essa amizade inadequada e perigosa, pois os tubarões eram os responsáveis por varias mortes na família. Já a mãe do tubarão avisa seu filho de que os peixes servem apenas para serem devorados. As duas mães, no entanto, concordam que ambos são inimigos mortais entre si sem direito à contestação. A história termina com a reaproximação do peixe e do tubarão que resolvem serem amigos independentemente dos fatos acontecidos nas gerações anteriores. Para Korczak, assim com na história de Shalit as crianças têm o poder de crescerem livres dos preconceitos criados por gerações, se assim forem educadas desde pequenas.

\footnotetext{
${ }^{136}$ Guilat Shalit é um jovem de 25 anos, soldado israelense, que foi capturado em 2006 em combate na Faixa de Gaza, por terroristas do Hamas. Ele continua preso até o presente momento. Os pais de Shalit publicaram o livro Keshehakarish vehadag nifggheshu Larishoná, como parte das manifestações para libertarem seu filho. O texto do livro foi escrito por Shalit quando ele tinha 11 anos de idade e segundo seus pais foi inspirado na profecia de Isaías 11: 6. E morará o lobo com o cordeiro, e o leopardo com o cabrito se deitarão, e o bezerro, e o filho de leão e os animais cevados andarão juntos, e um menino pequeno os guiará.
} 
Nesse sentido, afirmou que considerava a Terra de Israel um lugar ideal para abrigar crianças de todos os credos, pois, para ele, a Palestina abraçava tanto as verdades de Moisés como os conhecimentos de Jesus. Com isso Korczak demonstrou sua crença em uma sociedade pluralista e de coexistência pacífica.

Korczak expressou seu sentimento de impotência em defender a criança na Polônia e fez menção às dificuldades na vida dos poloneses, referindo-se ao desamparo e tristeza das crianças vítimas das artimanhas dos adultos, a quem ele se refere como animais, por causa da ascensão do nazismo. Ele se decepcionou com sua pátria polonesa na condição de espectador da tragédia que se desenrolava à sua frente, pela banalização da violência, e exprimiu novamente o desejo de se transferir para a Terra de Israel e lá estudar em um heder, em Jerusalém ou em Tiberíades. Entretanto, sabia que as maiores vítimas do nazismo eram as crianças, e por isso não poderia abandoná-las. Esse seu compromisso com elas era a razão pela qual não poderia se estabelecer definitivamente na Terra de Israel, ainda que, em algumas cartas, demonstrasse a esperança de passar os últimos anos de vida na Terra de Israel.

Por fim, as dificuldades impostas pela sociedade aos judeus poloneses devido ao crescente antissemitismo trouxeram-lhe angústias e dissabores. Ele tentou influenciar as autoridades em favor das duzentas crianças do orfanato judaico para que não fossem transferidas para o gueto de Varsóvia, mas seus esforços foram em vão. O orfanato funcionou dentro do gueto da mesma maneira como funcionava na Rua Krochmalna, 92, e, independentemente da abominável situação vivida pelos judeus dentro do gueto, Korczak, Stefa, os educadores e as crianças mantiveram-se fiéis aos princípios de ética e respeito humano. Ele lutou até os últimos dias de vida pelo direito das crianças de morrerem com dignidade. Seu desejo de viver na Terra de Israel não se realizou e sua vida terminou no campo de extermínio de Treblinka ao lado das duzentas crianças e dos educadores como Stefa entre outros.

O legado de Korczak foi de deixar tanto na educação quanto na questão sionista uma obra de inegável riqueza e atualidade. Com relação a essa última, a memória de Korczak não ficará completa se não contemplarmos seu interesse e apego ao judaísmo, à causa sionista e à Terra de Israel. Ainda há muito a se pesquisar e a análise de sua produção literária vinculada ao contexto histórico de sua vida e de suas experiências, certamente deverá contribuir para a compreensão da pertinência de Korczak à causa judaica e à questão sionista e que poderá servir como base de uma próxima pesquisa. Além disso, a multiplicidade de campos envolvidos na vida e no trabalho de Korczak dá abertura para inúmeras possibilidades de 
interpretações e pesquisas, que abrangem áreas como a Psicologia, a História, a Pedagogia, a Linguística e a Medicina pediátrica.

Que farei depois da guerra?

Talvez, chamar-me-ão para ajudar a construir uma nova ordem no mundo ou na Polônia? A coisa é pouco provável e, aliás, não gostaria disto. Ser obrigado a tornar-se funcionário [...]. Gosto de ter as mãos livres para agir. (Korczak, Diário no Gueto, 1986, p.22)

Tenho a intenção de escrever:

[...] Um romance em dois volumes. A história se passa na Palestina. A noite de núpcias de um casal de pioneiros ao pé do Monte Guilboa; no próprio lugar onde fora a fonte; fala-se desta montanha e desta fonte no livro de Moisés. (idem, p.13)

Terminada uma vez a guerra, as pessoas não poderão, por muito tempo, olhar-se nos olhos sem ler aí esta pergunta: Como é que você ainda está aqui? O que você fez para sobreviver? (idem, p.86)

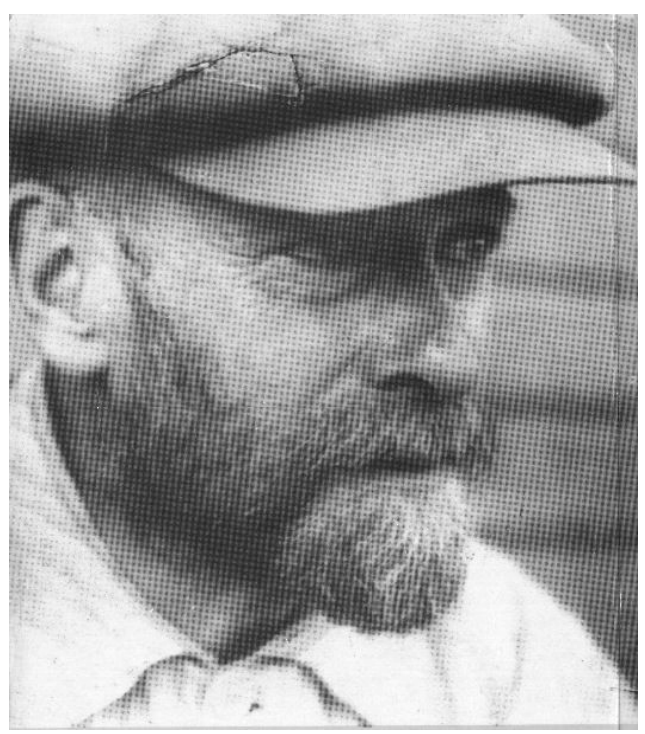

Imagem 41 - Korczak na Terra de Israel em 1936. Fonte: Beit Lohamei haghetaot

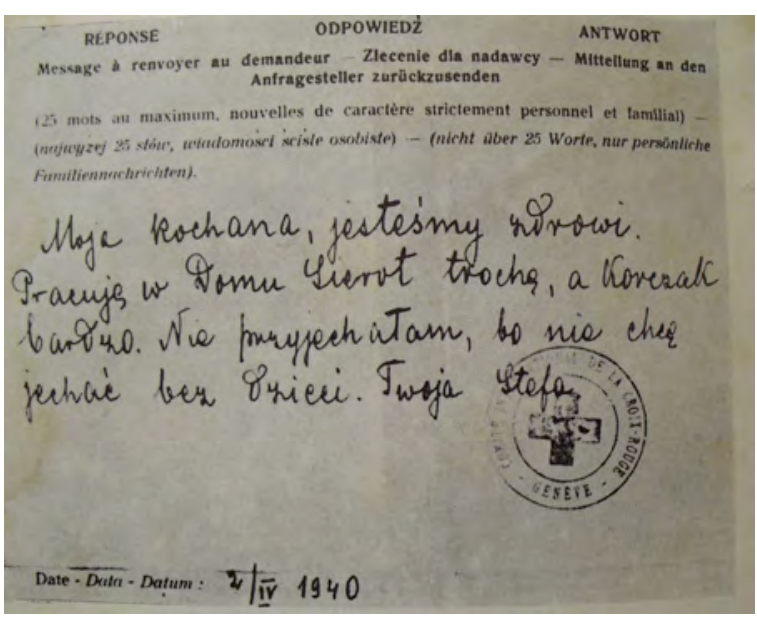

Imagem 42 - Cartão postal de Stefa enviada a Feiga Lipshitz para Palestina em 2-4-1940 por intermediário da cruz vermelha. Fonte: KORCZAK, 1972, p. 193. 


\section{Fontes}

KORCZAK, J. Como Amar Uma Criança (Parte I: Varsóvia 1919; Parte II: Varsóvia 1920). Edição Brasileira, São Paulo, Paz e Terra, 1983.

. Dat Hayeled. Israel, By Ghetto Fighters'House Ltd, 1978.

. Diário do Gueto. Tradução: Jorge Rochtlitz. Titulo original em francês: Journal Du

Gheto. Coleção Elos, Dirigida por J. Guinsburg. São Paulo, Perspectiva, 1986.

- Hamelekh Hamatia Harishon, helek rishon, O Rei Matheus Primeiro (Primeira

Edição: Varsóvia, 1922). Tradução do Polonês para o hebraico de Uri Orlev. Jerusalém, Beith Hotzaá keter. s/d.

. Min Hagheto (Dentro do Gueto), 1939-1942. Primeira Edição em Varsóvia de 1957.

Tradução de Tzvi Arad. Israel,By Ghetto Fighters`House Ltd., 1972.

Quando Eu Voltar a Ser Criança (Primeira Edição:Varsóvia, 1926). Tradução de Yan Michalski; coleção dirigida por Fanny Abramovich. São Paulo, Summus editorial, 1981.

Loving Every Child, Wisdom for Parents. New York, Harper Collins Publishers, 2007.

.Como Amar Uma Criança.Tradução de Sylvia Patrícia Nascimento Araujo. Rio de Janeiro, Paz e Terra, 1983. 


\section{Iconografia}

Imagem 01 - A primeira página do jornal "Hamaguid" do dia 5/02/1865 contendo o artigo escrito por Hirsh Goldszmit, com sua assinatura no final do artigo à esquerda. Éden, S. 2000, p.239. Arquivo The Janusz Korczak Association in Israel.

Imagem 02 - Página de rosto do livro Talmud e o Divórcio de Joseph Goldszmit, pai de Korczak. Éden, S. 2000, p.240. Arquivo The Janusz Korczak Association in Israel.

Imagem 03 - A criança Henryk Goldszmit (Korczak) com aproximadamente 10 anos. Arquivo Beit Lohamei Haghetaot.

Imeges 04 - Korczak em 1907 em uma colônia de férias. Arquivo Beit Lohamei Haghetaot.

Imagem 05 - Korczak e Stefa em 1909. Arquivo Beit Lohamei Haghetaot.

Imagem 06 - Korczak, o terceiro da esquerda para a direita, em 1908 com os colegas da Faculdade de Medicina. Arquivo Beit Lohamei Haghetaot.

Imagem 07 - Capa do livro de Korczak Moski, Joski e Sruli publicado em Varsóvia: 1910. Éden, S. 2000, p.160. Arquivo The Janusz Korczak Association in Israel.

Imagem 08 - Korczak ao centro, à esquerda Dr. Eliasberg e a direita Stefa Wilczynska no orfanato Don Sierot em 1923. Arquivo Instituto Morashá de Cultura, Ano XVI, Dez/2008, n 63, p.25.

Imagem 09 - Orfanato em Varsóvia na Rua Krochmalna, 92 chamado Don Sierot. Arquivo Beit Lohamei Haghetaot.

Imagem 10 - Refeitório e dormitório do orfanato Don Sierot em 1929. Arquivo Beit Lohamei Haghetaot.

Imagem 11 -Réplica dos cartões postais de Korczak às crianças do Orfanato. Arquivo Beit Lohamei Haghetaot.

Imagem 12 - Korczak com as crianças no orfanato Don Sierot na década de 30 ....39

Imagem 13 - À esquerda, Maryna Falska (segunda da esquerda para direita) em sala de aula e à direita jogo de futebol no pátio do orfanato Nasz Dom em 1924 42

Imagem 14 - Stefa com bebê, no Kibutz Ein Harod, Israel, 1931 45 
Imagem 15 - Ficha cadastral nazista preenchida por Korczak no gueto de Varsóvia em 1939

Imagem 16 - Korczak com seus amigos Haim Burshtein e Ari Kalisher (de óculos, foi aluno de Korczak no Orfanato e redator do jornal infantil Mali Psheglond), em Varsóvia no ano de 1939 47

Imagem 17 - Convite para a peça de teatro O Correio representada pelos alunos de Korczak no gueto de Varsóvia em 18/07/1942 48

Imagem 18 - A última foto de Korczak no Gueto de Varsóvia em 1941 49

Imagem 19 - Primeira edição de Der Judenstaat de Theodor Herzl, 1896 56

Imagem 20 - Korczak entre os educadores em um seminário para professores em Varsóvia 58

Imagem 21 - Os jovens educadores da Bursa. s/d 59

Imagem 22 - Korczak ao centro, em baixo, em 1938 no seminário de educadores do movimento juvenil judaico Hashomer Hatzair em Varsóvia

Imagem 23 - Boletim informativo do Keren Kayemet Leisrael (KKL) de 1925, contendo as assinaturas dos representantes da Intelligentsia judaica de Varsóvia com as correções escritas à mão por Korczak. A assinatura de Korczak é a primeira da coluna da direita

Imagem 24 - Primeira página do Alim, contendo a entrevista que Korczak concedeu a Yerachmiel Weingarten em 1925 65

Imagem 25 - Primeira página do encarte infantil Mali Psheglond em 1936 .71

Imagem 26 - Na fotografia à esquerda, Ester Budko Gad com Yerachmiel Weingarten no Kibutz Ein Harod em 1977. Na fotografia à direita, Stefa, entre a família de Feiga Lipshitz no Kibutz Ein Harod na década de trinta

Imagem 27 - Korczak com a família Samhoni à sua esquerda e Gur-Arieh à sua esquerda no kibutz Ein Harod em 1934 85

Imagem 28 - Korczak no Kibutz Ein Harod em 1934 .87

Imagem 29 - Korczak entre a equipe da cozinha do Kibutz, Ein Harod, em 1934 ...88

Imagem 30 - Korczak com as crianças de Ein Harod em 1936 .89

Imagem 31 - As crianças do orfanato no sítio Little Rose na década de 1920 ......... 94

Imagem 32 - O sítio Little Rose na década de 1920 94

Imagem 33 - Página das anotações de Korczak sobre sua viagem à Terra de Israel em 1936 com o tema de A nova epopéia

Imagem 34 - Korczak em 1936 com as crianças e educadores de Ein Harod......... 112

Imagem 35 - Korczak no caminho de volta da Palestina em 1936. 119 
Imagem 36 - Aviso no jornal polonês judaico Mali Psheglond sobre a palestra de Korczak com o tema: "Seis semanas na Palestina”, em 1936

Imagem 37 - Avisos de palestras de Korczak em 1937 no jornal polono-judaico de Varsóvia com o tema de: A criança judia da Polônia e da Palestina

Imagem 38 - Korczak e Stefa na década de 1930 em Varsóvia

Imagem 39 - Korczak no seminário de educadores do movimento juvenil Hehalutz Hatzair em 1939

Imagem 40 - Cópia da última carta de Korczak para seu amigo de Ein Harod em 1939 128

Imagem 41 - Korczak na Terra de Israel em 1936 134

Imagem 42 - Cartão postal de Stefa enviada a Feiga Lipshitz para Palestina datada de 2-4-1940 por intermediário da cruz vermelha 134 


\section{Bibliografia Específica}

ARNON, J. Quem foi Janusz Korczak? Tradução de Fanny Feffer dirigida por J. Guinsburg. São Paulo: Perspectiva, 2005

ÉDEN, S. Henryk Goldszmit - Janusz, Korczak: Haadam, Hamehanekh, Hasofer (Janusz Korczak - The Man, The educator, The Writer). The Janusz Korczak Association in Israel: Jerusalém, 2000.

KORCZAK, J. (1878-1942) Coletânea de Pensamentos. São Paulo: Ben Abraham, 1998.

LIFTON, B.J. The King of Children, The Life and Death of Janusz Korczak. United States: American Academy of Pediatrics, 2005.

MARANGON, A. C. R. Janusz Korczak - Precursor dos direitos da criança: uma vida entre obras. São Paulo: Editora UNESP, 2007.

PERLIS, I. Ish Yehudi Mepolin - Haio Upeulo Shel Janusz Korczak, Beith Lohamei Hghetaot by Ghetto Fighter' House, Israel Ltd: 1986.

SHNER, M. Dor le dor: Studies in the History of Jewish Education, In Israel and the Diaspora; XXXIII; Interdisciplinary Studies of the Legacy of Janusz, Korczak. Published by The schools of education of Ben-Gurion University of the Negev; Bar-Ilan University; Haifa University; Tel aviv University; The Hebrew University, Jerusalem, The open University of Israel and Archives of Jewish Education in Israel and the Diaspora in Memory of Aviezer Yellin, in cooperation with the Janusz Korczak Association in Israel an Beit Lohamei Haghetaot. Tel-Aviv University, 2008. Beit Lohamei Haghetaot: 2008.

SINGER, H.; LEWOWICKI, T.; Murahovschi, J. Janusz Korczak - Perfil, lições, “O Bom Doutor". São Paulo: Edusp, 1998.

SZPICZKOWSKI, A. Educação e Talmud: uma releitura da Ética dos Pais. São Paulo: Humanitas-FFLCH/USP, 2002. 
. "Religiosidade e Educação em Janusz Korczak". In: Dora Incontri(organizadora).

Educação e Espiritualidade, Interfaces e perspectivas. São Paulo: Comenius, 2010, pp. 147-158.

. "Janusz Korczak: pertinência ao judaísmo". In: coordenação de LEWIN, H. Judaísmo e globalização: espaços e temporalidades. Rio de Janeiro: Imprimatur, 2010, pp 489-495.

Janusz Korczak: uma abordagem educacional. São Paulo: LEI/USP - Laboratório de Estudos sobre a Intolerância da Universidade de São Paulo, 2008 (Aula on-line).

TANNEENBAUM, A. Janusz Korczak of the children, Museum Yad Layeled, Beit Lohamei Haghetaot.

WEINGARTEN, Y. Janusz Korczak Haiehudi Hameunê, Sipur Chaiav Utkufato. Tel aviv: Hotzaat Bronfman, 1979.

\section{JORNAL:}

MAARIV, Lehitraot Yeladim Israel 28/01/11 pp 22-27, sofash@ maariv.co.il

\section{REVISTA:}

Revista Morashá, “Janusz Korczak e seu Diário do Gueto”, Ano XVI- Dezembro 2008, nº 63. 


\section{Vídeos:}

KORCZAK SHEL YELADIM. Haaguda shel Janusz Korczak Shel Yeladim; Seret Documentari. Beith Lochamei Haguetaot - Em tradução livre: "Korczak das crianças". Documentário em vídeo sobre Janusz Korczak adquirido no museu Iad laieled, no kibutz Lochamei Hghetaot, Israel, em 2010.

WAJDA, ANDREJ (direção), As duzentas crianças do Doutor Korczak. Polônia: 1999, legendado. 


\section{Biliografia}

ACKERMAN, D. O Zoológico de Varsóvia. São Paulo: Nova Fronteira, 2008.

ADORNO, T.; HORKHEIMER, M. Dialética do esclarecimento: fragmentos filosóficos. Tradução autorizada da edição alemã publicada em 1969 por S. Fischer Verlag, GmbH, de Frankfurt em Main, Alemanha. Rio de Janeiro: Editora Zahar, 1985.

AQUILES VON ZUBER, N.; BUBER, M. Cumplicidade e diálogo. Bauru, SP: Edusp (editora da Universidade do Sagrado Coração), 2003.

ARENDT, H. Origens do totalitarismo, anti-semitismo imperialismo totalitarismo. São Paulo, Companhia das Letras, 2009.

AVINERI, Sh. La Idea Sionista: Notas sobre El pensamiento nacional judio. Jerusalén: La Semana Editores, 1988.

BARNAVI, E. (org.) Historia Universal dos Judeus, da Gênese ao fim do século XX. São Paulo: Editora Cejup, 1995.

BAUMAN, Z. Holocausto e Modernidade. Rio de Janeiro: Zahar, 1989.

BAUMGARTEN, J.; ERTEL, R.; NIRBORSKI, I. \& WIEVIORKA, A. (orgs.). Mil Anos de Culturas Asquenazes. Trad. Nilson Moulin e Sara Rosenchan São Paulo: Editora Bispo, 2010. BEREZIN, R. Dicionário hebraico-português. São Paulo: Edusp, 1995.

BETTELHEIM, B. A Viena de Freud e outros ensaios. Rio de Janeiro: Editora Campos, 1991.

BORGER, H. Uma Historia do Povo Judeu: das Margens do Reno ao Jordão. São Paulo: Editora e Livraria Sêfer, 2002, Volume 2. 
CARNEIRO, M.L.T. Cidadão do mundo, o Brasil diante do Holocausto e dos judeus refugiados do nazifascismo (1933-1948). São Paulo: Perspectiva, 2010. Inventários Deops - Alemanha. São Paulo: Arquivo do Estado, 1997.

CROCHILK, J. L. Preconceito, indivíduo e cultura. $3^{\mathrm{a}}$ ed. São Paulo: Casa do Psicólogo, 2006.

CYTRINOVICZ, R. Memórias da Barbárie, A História do Genocídio dos Judeus na Segunda Guerra Mundial. São Paulo: Nova Stella / Edusp, 1990.

DALlARI, D. A. Janusz Korczak: O Direito da Criança ao Respeito. São Paulo: Summus Editorial, 1986.

DUARTE, R. Adorno/Horkheheimer \&. A dialética do esclarecimento. $2^{\mathrm{a}}$ edição. Rio de Janeiro: Jorge Zahar Editor, 2004.

ECO, U. Como se faz uma tese. São Paulo: Perspectiva, 1977.

FREUD. S. Pensador e Cultura. São Paulo: Brasiliense, 1986.

HOBSBAWN, E. A Era dos Impérios 1875/1914. São Paulo:Paz e Terra, 2010.

HOBSBAWN, E. Nações e nacionalismo desde 1780 - Programa, Mito e Realidade. São Paulo: Paz e Terra, 2008.

ISAACSON, W. Einstein: sua vida, seu universo, São Paulo: Companhia das Letras, 2007.

KAFKA, F. Carta ao Pai. Tradução de Modesto Carone. São Paulo: Companhia das Letras, 2002.

KIMMERRLING, B. O Fim da Hegemonia Ashkenazita. Tradução e notas: Gabriel Mordoch. Jerusalém: 2001.

MASSADIÉ, G. História Geral do Antissemitismo. Rio de Janeiro: Bertrand Brasil, 2003.

OZ, A. In the land of Israel, USA: Keter Publishing House Ltd., 1993.

PINSKY, J. Origens do nacionalismo judaico. São Paulo: Ática, 1997. 
RABIN, C. Pequena história da Língua Hebraica. São Paulo: Summus Editorial, 1973.

SARAMAGO, J. Ensaio sobre a Cegueira. São Paulo: Companhia das Letras, 1922.

SHALIT, G. Keshehacarish vehadag nifgheshu lerishona, Israel: 2007.

SHOLEM, G. Walter Benjamin: a história de uma amizade. São Paulo: Perspectiva, 2008.

SINGER, I.B. Shosha, São Paulo: Francis, 2005.

TODOROV, T. O homem desenraizado. Rio de Janeiro: Record, 1999.

TWIM, J. My, Zydzi, Polscy, Kwiaty Polskie, Wydawnicwa Artystyczne I Filmove, Warsawa, 1998.

UNTERMAN, A. Dicionário Judaico de lendas e tradições. Rio de Janeiro: Jorge Zahar Editor, 1993.

WIESEL, E. O Tempo do desenraizados. Rio de Janeiro: Record, 2003. 